\title{
The Legend of La Corriveau: Québécois Folklore and The Politics of Nation-Making in Canada
}

by

\author{
Leslie Savath
}

A thesis submitted to the Faculty of Graduate and Postdoctoral Affairs in partial fulfillment of the requirements for the degree of

Doctor of Philosophy

in

English

Carleton University

Ottawa, Ontario

(C) 2021

Leslie Savath 


\section{Abstract}

This dissertation examines the role played by Québécois folklore in Canadian metanarratives of nation using as a case study "La Corriveau," a Québécois murderess whose folkloric tale emerged during the pivotal British Conquest of New France in 1760. It analyzes how the figure of La Corriveau expresses and mediates conflicts between English and French Canada in both literary traditions. Reading through intertextual and interlingual lenses francophone and anglophone texts addressing the legend of $\mathrm{La}$ Corriveau such as Philippe Aubert de Gaspé's Les anciens Canadiens (1863), William Kirby's The Golden Dog (1877), Victor-Lévy Beaulieu's Ma Corriveau (1973), Anne Hébert's La cage (1990), and Douglas Glover's “La Corriveau” (1993), as well as examining La Corriveau's portrayal in life writing, popular film, and the global marketplace, this dissertation argues that the legend and its reinterpretations are reworked by both Québécois and English-Canadian authors in a desire to recuperate the figure for distinct national metanarratives of Québec and English Canada. For Québécois writers, the legend has provided a semantically flexible focal point for national image-making across a range of historical contexts and ideological positions, from French-Canadian survivance to Québécois nationalism and settler nationalism. For English-Canadian writers, meanwhile, and in constant dialogue with Québécois uses of the legend, La Corriveau has been made to serve an equally complex and often contradictory role in narratives that alternately (and sometimes simultaneously) reinforce, question, and rewrite English-Canadian metanarratives of romantic nationalism. As it traces ongoing conversations among Québécois, English-Canadian, as well as other francophone and anglophone revisions of the legend, this dissertation shows not only how La Corriveau 
has developed as a mediator of French- and English-Canadian identity, but also how its treatment continues to regulate images of Indigenous presence in relation to those national metanarratives. 


\section{Acknowledgements}

First and foremost, I would like to thank Dr. Elspeth Tulloch for introducing me to Canadian literature. She made what I assumed would be dry material engaging to the extent that it became one of my areas of research. In particular, our courses on the place of Québec in Canada made me think a lot about my place as an anglophone Laotian Canadian pursuing an English degree in a francophone city, in an Anglo-dominated country. I am also grateful to Dr. Jean-Philippe Marcoux, Dr. Brad Kent, Dr. Liani Lochner, and all of my colleagues from Université Laval for sharing with me their passion for literature. I cherish my time in Québec City and the friendships I made there very fondly.

Since returning to Ottawa, Carleton University has been my home. The faculty, staff, and students of the English department have created such a warm and welcoming environment. My thanks go out to Lana Keon, priya kumar, Dr. Julie Murray, and Dr. Travis DeCook for their continuous support. Denize Tan and Christine Taylor from the MacOdrum Library also played key roles in helping me locate crucial sources for my dissertation.

I am immensely indebted to Dr. Brian Johnson for guiding me through my entire doctoral journey, even before it officially started. It was a privilege to work under such a kind, devoted, and caring supervisor who never hesitated to congratulate me for my achievements and to share comforting words during tougher moments. He has contributed, without a doubt, to me becoming a better scholar and person. I would also like to express my gratitude to Dr. Catherine Khordoc and Dr. Jody Mason. Catherine, you made me discover a wide array of fascinating works and criticism on Québécois 
literature, and consequently made me want to shift my research to incorporate Québécois content. You always encouraged me to find my own voice and position within the various debates on nationalism, feminism, and so on. I truly appreciated our numerous conversations and look forward to many more! Jody, you have certainly challenged me with tough questions that pushed me to think even more critically about my work. Thank you for your generosity and patience. I am lucky to have had you on my committee! My family and friends were an invaluable support system and never hesitated to provide me with much needed time to focus on my work. A huge thanks to those who partook in my coffee-and-thesis-writing café sessions! At home, my cuddly little furballs, Aria and Toccata, were the most amazing study companions I could have. Finally, my most heartfelt gratitude to Olivier Jacques, without whom I would not have started my doctoral studies. To say the least, it was comforting to go through the numerous milestones of the bachelor's, master's, and $\mathrm{PhD}$ with you! Thank you, always, for your unwavering encouragement and love. 


\section{Table of Contents}

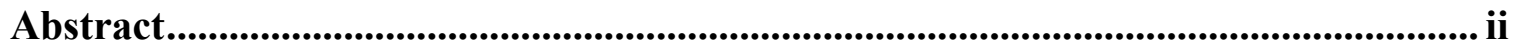

Acknowledgements ......................................................................................................... iv

Table of Contents ............................................................................................................... vi

List of Illustrations......................................................................................................... viii

Chapter 1: Introduction ...................................................................................................... 1

1.1 Emergence of the Legend in Cultural Imagination.......................................................2

1.2 Romantic Nationalism and the Metaphors of Nation in English Canada and Québec. 10

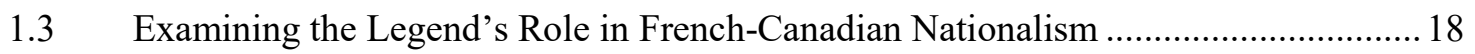

1.4 Examining the Legend's Sociopolitical Functions in National Frameworks ...............20

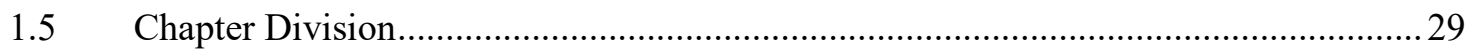

Chapter 2: Nation Building, Legend Making..................................................................... 33

2.1 Marie-Josephte's Vilification: Crystallizing Her Infamy …........................................ 37

2.2 Transformations in the Legend and French-Canadian Nationalism ............................ 42

2.3 La Corriveau in the Service of English-Canadian Romantic Nationalism ...................57

2.4 The French-Canadian Aristocracy and British Political Ascendency in Les anciens

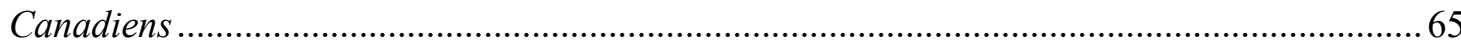

2.5 The Flexible Strategy of terra nullius in The Golden Dog........................................ 88

Chapter 3: WomaNation in Québécois Plays on La Corriveau.................................. 109

3.1 From Indigenous to Québécois: La Corriveau's New Nationalist Association.......... 119

3.2 From Villain to Vixen: Challenging Québec's Feminized, Colonial Condition in $M a$

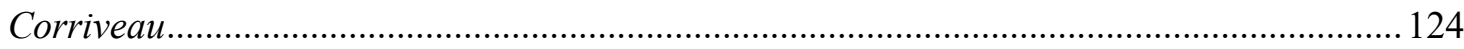

3.3 Transforming (M)Otherhood through New Af/filiations in La cage ............................ 160

Chapter 4: The Legend of La Corriveau Beyond Québec ............................................ 185

4.1 Satire and Subversion in "La Corriveau" ............................................................... 190 
4.2 Reconstructing the Corriveau Genealogy in An Object of Conviction ........................ 216

4.3 "Dessine-moi dans des habits de sorcière divine": Divinity, Love, and Self-Sacrifice in Poupée de rouille.

Chapter 5: Commodifying the Legend of La Corriveau ........................................ 247

5.1 Haunted Canada Stamps: Returning to Old Canadian Landscapes and Debates .......252

5.2 The Return of La Corriveau's Gibbet to Québec City ..............................................264

5.3 Brewing the Legend of La Corriveau at Le Bilboquet Microbrewery ...................... 280

\section{Chapter 6: Re-Indigenizing La Corriveau in Contemporary Québécois Discourse}

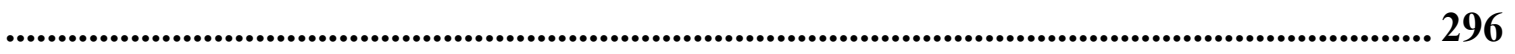

6.1 Battling for Québécois Settler Nationalism in Nouvelle-France ..............................299

6.2 Going Native and Subverting a Genealogical Fantasy in Le crépuscule des arcanes 312

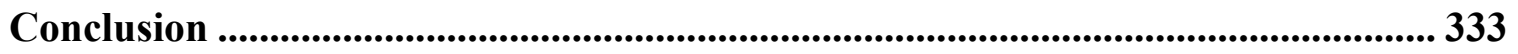

Bibliography ......................................................................................................................... 344 


\section{List of Illustrations}

Illustration 1 Haunted Canada Postage Stamps, Second Collection................................. 255

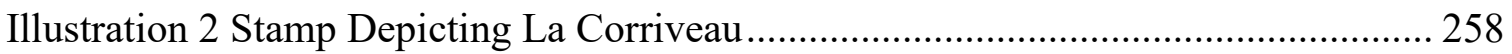

Illustration 3 Haunted Canada Postage Stamps, Third Collection.................................... 261

Illustration 4 Stamp of the Métis Ghosts at Red River ..................................................... 263

Illustration 5 Haunted Canada Postage Stamp, First Collection..................................... 263

Illustration 6 The Iron Gibbet with a View of the Bottom and Left Sides ..................... 270

Illustration 7 The Iron Gibbet with a View of the Top and Right Sides.......................... 271

Illustration 8 "La Corriveau” Beer Label with Description............................................ 286

Illustration 9 "La Corriveau” Beer Label without Description ....................................... 287

Illustration 10 "La Corriveau Impériale" Beer Label .................................................... 289 


\section{Chapter 1: Introduction}

Dans les barreaux d'une cage de fer Mise vivante et pendue en l'air

La Corriveau devait expier De faim, de froid, devait expirer

Oyez, oyez, gens de ce pays Gens du présent du passé aussi Gens du futur qui en parlerez La Corriveau, vous l'appellerez

"La Corriveau" by Gilles Vigneault In 1966, Gilles Vigneault wrote the song "La Corriveau" for an eponymous dramatic ballet about the legend of La Corriveau as part of the Confederation's one-hundredth anniversary celebrations. An article in Le Devoir dating back to November 24, 1966, describes La Corriveau as a "ballet dramatique de style contemporain, [qui] sera présenté les 21 et 22 décembre" and performed by Les Grands Ballets Canadiens in collaboration with the Montreal Symphony Orchestra at the Salle Wilfrid-Pelletier, Places des Arts in Montreal ("La saison des grands ballets canadiens" 10). ${ }^{1}$ This joint project brought together popular names from the Québécois arts scene. The music was written by Alexander Brott, "one of the most important anglophone composers to have made his career in Québec" (“Alexander Brott”). The lyrics were written by Vigneault, one of the highly influential “icons of Quebec's musical history" (Piroth 148), and interpreted by Québécois folksinger Raoul Roy. The ballet was choreographed by Brydon Paige, with décor and costumes by Claude Girard ("La saison des grands ballets canadiens" 10).

\footnotetext{
${ }^{1}$ A contemporary dramatic ballet, which will be presented on December 21 and 22. Unless otherwise specified, all translations are mine.
} 
In organizing the centennial celebrations, the Canadian Confederation Centennial Commission had specific objectives in mind, all of them pertaining to the consolidation of a unified Canadian national narrative. Some of these objectives included "reinforc[ing] the identity of the organism," "seek[ing] out and accentuat[ing] unifying elements," and "analyz[ing] destructive forces that may be present" (Aykroyd 11). To fulfill these goals, it was necessary to study carefully "all the dimensions of that identity" and research symbols, songs, and other cultural elements that could represent it (Aykroyd 11). More importantly, it was imperative to develop strategies to "aggressively oppose" any and all destructive forces that would contradict such identity (Aykroyd 11). Luc Lacourcière's observation that 'il n'est guère de femme, dans toute l'histoire canadienne, qui ait plus mauvaise réputation que Marie-Josephte Corriveau, appelée communément la Corriveau" ("Le triple destin" 39) makes it all the more surprising that the Commission would want to feature a macabre tale about a gibbeted witch who torments passersby. ${ }^{2}$ How does La Corriveau reinforce Canadian identity? How does she accentuate unity and aggressively oppose destructive forces? Or is she a destructive force that needs to be mitigated?

\subsection{Emergence of the Legend in Cultural Imagination}

Marie-Josephte Corriveau, known as "La Corriveau," was born in January or

\footnotetext{
${ }^{2}$ There is no woman, in all of Canadian history, who has a worse reputation than Marie-Josephte Corriveau, commonly referred to as La Corriveau.
} 
February 1733 in Saint-Vallier de Bellechasse. ${ }^{3}$ In 1749, at the age of sixteen, she married Charles Bouchard and had three children: Marie-Françoise, Marie-Angélique, and Charles (Ferland and Corriveau 34, 37). Her husband died from putrid fever in April 1760, and she quickly remarried Louis-Étienne "Louis" Dodier. ${ }^{4}$ She was heavily criticized by her community for marrying a younger bachelor. ${ }^{5}$ Although Marie-Josephte was initially infatuated with Dodier, she became confined in her relationship and experienced domestic violence. ${ }^{6}$ Marie-Josephte's father, Joseph Corriveau, had an extremely difficult relationship with Dodier. They frequently quarreled and even made death threats against each other (Lacourcière, "Le triple destin" 52; Ferland and

\footnotetext{
${ }^{3}$ Catherine Ferland and Dave Corriveau provide Marie-Josephte Corriveau's biography in "Chapitre 1: vivre en Nouvelle-France." This chapter falls under "Partie I : historique." As the title suggests, this section is grounded in their archival research and the historical documents they found pertaining to Marie-Josephte Corriveau's life and court trials. It contrasts Part II on the legend and the figure of La Corriveau's presence in "la mémoire collective et au niveau patrimonial" [collective memory and at the patrimonial level] (Ferland and Corriveau 23). Ferland and Corriveau estimate Marie-Josephte's birth date according to her baptismal record dated May 14, 1733, and the fact that she was approximately three months old (27-28). Bertrand Bergeron and Jean-Pierre Pichette include Marie-Josephte's biography as an appendix to their edited collection of Lacourcière's publications on La Corriveau. They draw on Lacourcière's encyclopedic entry called "Corriveau, Marie-Josephte" from the Dictionnaire biographique du Canada, vol. III (17401770) published in 1974. Bergeron and Pichette only mention the baptismal record, which they also note as May 14, 1733 (137). As a side note, my page numbers for Ferland and Corriveau come from the second edition of La Corriveau : de l'histoire à la légende published in 2014.

${ }^{4}$ Lacourcière affirms that Bouchard's death took place on April 20 ("Le destin posthume" 73) whereas Ferland and Corriveau claim it took place on April 25 (56).

${ }^{5}$ In works such as Andrée LeBel's La Corriveau (1990) and Monique Pariseau's La fiancée du vent (2003), La Corriveau is chastised by her community for remarrying so quickly after her first marriage and consequently disgracing Bouchard's memory. However, remarrying within the first year of mourning was common for women after the events of 1759 (Ferland and Corriveau 65). Ferland and Corriveau explain that remarriages between widows and young bachelors were frowned on because they "lèsent les jeunes célibataires tout en risquant de désavantager les enfants du premier lit. De surcroît, dans ce type d'union où la femme est plus âgée que son époux, l'autorité maritale ne risque-t-elle pas d'être compromise?" [harm young bachelors and also risk harming the children from the first marriage. Furthermore, in this type of union wherein the woman is older than her spouse, does the marital authority not risk being compromised?] (66).

${ }^{6}$ Lacourcière transcribes court documents stating that "Maria Josephe Corriveaux ... adds that it was indeed a good deal owing to the ill Treatment of her husband, she was guilty of this crime" (56, italics in original). Critics interpret Marie-Josephte's claim of ill-treatment as domestic violence (Bergeron and Pichette 20, 33; Ferland and Corriveau 140, 251).
} 
Corriveau 69). ${ }^{7}$ Unsurprisingly, when Dodier's corpse was found in his own barn on January 27,1763 , Joseph Corriveau was immediately suspected of murder. ${ }^{8}$ While the death was quickly dismissed as an accident, the brother of the deceased requested a thorough investigation. Military governor James Murray granted his request and ordered the body's exhumation, which confirmed Dodier's death as a homicide. As a result, Joseph Corriveau and his daughter were arrested, the latter accused of being an accomplice in the murder. The timing of the legal procedures relating to Dodier's murder complicated the case and played against Marie-Josephte and her father, since the Treaty of Paris ceding New France to Britain was signed on February 10, 1763, and the

\footnotetext{
${ }^{7}$ According to Lacourcière, they often fought over the use of a horse they mutually owned, as well as over the use of a bread oven. Ferland and Corriveau attribute the numerous disputes to the upkeep of the land, the mutually owned horse, and the use of Joseph's bread oven.

${ }^{8}$ The parish priest, Thomas Blondeau, and the militia captain, Jacques Corriveau (bearing no relationship to Marie-Josephte's family), wrote an official report declaring that Dodier's death was an accident caused by his horse stomping on him. Lacourcière translates the report as follows: "En l'année 1763, le 27 janvier à 7 heures du matin, je fus appelé à examiner le corps de Louis Dodier, qui a été tué dans son étable par son cheval, et j'étais alors accompagné de Charles Denis, Joseph La Plante, Paul Gourges, Jean D'Allaire, Michel Clavet, Jean-Baptiste La Ramée, Zacharie Montigny, Ignace La Case, Claude Dion, qui tous ont déclaré qu'ils avaient vu et examiné le corps du dit Louis Dodier, encore sous les pieds de ses chevaux, et qu'il avait reçu plusieurs coups à la tête. Voilà ce que les personnes ci-dessus mentionnées ont déclaré au jour et à l'heure indiqués plus haut, quelques-uns ayant signé, les autres ayant déclaré ne pas savoir écrire" [In the year 1763, on January 27 at 7 o'clock in the morning, I was called to examine the body of Louis Dodier, who was killed in his stable by his horse, and I was accompanied by Charles Denis, Joseph La Plante, Paul Gourges, Jean D'Allaire, Michel Clavet, Jean-Baptiste La Ramée, Zacharie Montigny, Ignace La Case, Claude Dion, who all declared having seen and examined the body of said Louis Dodier, still under his horse's hooves, and that he had received multiple strikes to the head. That is what these abovementioned people declared on the day and time indicated above, a few having signed, the others having declared they did not know how to write] ("Le triple destin" 43). This report was signed by Jacques Corriveau, who acted as the coroner, and Paul Gourges, one of the witnesses. The listed witnesses confessed at the first trial that they believed the report was a mere formality to notify the authorities. They also mentioned that Dodier's death did not look like an accident and that he may, in fact, have been murdered with a pitchfork or some other agricultural tool (Lacourcière, "Le triple destin" 44-50; Ferland and Corriveau 91). Lacourcière does not include the original text in his study. Ferland and Corriveau reproduce Lacourcière's translation in their historical account of Dodier's death (73). Furthermore, Major James Abercrombie's decision to inhume Dodier immediately after the accident was reported contradicted funeral customs of the French Régime. Suspicious neighbours thus interpreted this haste as Joseph Corriveau's attempt to conceal evidence of murder (Ferland and Corriveau 75).
} 
Corriveau trials began on March 29. ${ }^{9}$ The British military tribunal sentenced Joseph

Corriveau to hanging. Marie-Josephte, charged as an accomplice, was to receive sixty

lashes as punishment and be branded on the hand with an M for murder (Lacourcière, "Le triple destin" 54; Ferland and Corriveau 117). ${ }^{10}$

Shortly after receiving his sentence, Joseph revealed to the priest (and later

reported to Governor Murray), that he lied in order to protect his daughter (Lacourcière,

"Le triple destin" 57; Ferland and Corriveau 119-121). An expeditious second hearing

was called on April 15, resulting in Marie-Josephte being charged as the sole murderer of

\footnotetext{
${ }^{9}$ A British military regime was instated between 1760-1763. While the periodization of the military regime officially begins in 1760 after Montreal capitulated to the British military and ends in 1763 after the Treaty of Paris was signed, some scholars use the dates 1759-1764 since the occupation of the military regime actually began in Québec City following the Battle on the Plains of Abraham in 1759, and ended in 1764 once a civil government was established. This short period of time marks the gruelling transition from a French regime to a British one. The British legal procedures follow the practice of a civil court, which typically includes a judge, a plaintiff, a defendant, and attorneys. The fact that the French civil code does not require attorneys made excruciating the task of finding a qualified attorney in New France to represent Joseph and Marie-Josephte Corriveau. During the reign of the military regime, Marie-Josephte did not appear in front of an English civil court, nor the Conseil supérieur de Québec; she did not have access to a proper, legal hearing, and was instead subjected to a court martial. The French notary Jean-Antoine Saillant was appointed as the lawyer defending Marie-Josephte and her father. While he was somewhat knowledgeable about the practice of law (as a notary and son of a prominent French lawyer), he was unfamiliar with British law, which varied significantly from French law, and therefore was unable to defend his clients adequately. Furthermore, unlike the Crown prosecutor Hector Theophilus Cramahé, Saillant was not fluent in English, the language in which the trial primarily took place. Lacourcière notes that all the documents relating to the trials were in English with no indication of a translator or interpreter being present ("Le triple destin" 41). He adds that "les accusés et les habitants de Saint-Vallier, appelés à témoigner, ne connaissaient vraisemblablement pas l'anglais, non plus que l'avocat Saillant désigné par la cour. Par contre, Cramahé connaissait bien le français, étant lui-même descendant de huguenots réfugiés en Angleterre" [The accused and the inhabitants of Saint-Vallier, called to testify, were not likely to know English, and neither did the court's designated lawyer Saillant. On the other hand, Cramahé knew the French language well as he was a descendant of Huguenots who sought refuge in England] (Lacourcière, "Le triple destin" 41-3). Composing the military tribunal were British soldiers who barely knew any French. Hence, this substantial linguistic barrier obstructed the case and largely contributed to the guilty convictions of the Corriveau party.

${ }^{10}$ Furthermore, one of the witnesses, Marie-Josephte's cousin Isabelle Sylvain, was condemned to thirty lashes and the branding of the letter $\mathrm{P}$ on her hand for perjury as she continuously provided contradictory statements throughout the first trial (Lacourcière, "Le triple destin" 30; Ferland and Corriveau 118).

Ferland and Corriveau take this information from a document called Copy of the Proceedings of a General Court Martial Held at Quebec the 15th Day of April 1763, By Virtue of a Warrant from His Excellency Governor Murray, Dated the 14th Day of the Same Month. Lacourcière does not mention his source, but transcribes the original English verdict pronounced by James Murray.
} 
Louis-Étienne Dodier. In the Copy of the Proceedings of a General Court Martial Held at Quebec the 15th Day of April 1763, By Virtue of a Warrant from His Excellency

Governor Murray, Dated the 14th Day of the Same Month, James Murray stated that "Maria Josephe Corriveaux widow Dodier declares she murdered her husband Louis Helene Dodier in the night, that he was in bed asleep, that she did it with a hatchet" and that this murder was "a good deal owing to the ill Treatment of her husband" (Murray qtd. in Lacourcière, "Le triple destin" 56). ${ }^{11}$ Marie-Josephte claimed that she murdered her husband because he mistreated her during their marriage, but domestic abuse was not considered a crime at the time. Consequently, in addition to execution, Marie-Josephte was sentenced to "hanging in chains," an expression that refers to the use of a gibbet, a cage that encloses around an individual's limbs and torso. ${ }^{12}$ She was executed on April 18, 1763, at Buttes-à-Nepveu near the Plains of Abraham, and then exposed in her iron gibbet in Pointe-Lévy at the crossroads of the villages Lauzon and Bienville (Lacourcière, "Le triple destin" 59; Ferland and Corriveau 124). While under normal circumstances, Marie-Josephte would have hanged in chains in her hometown, SaintVallier, Governor Murray wanted all passersby from Québec and the South Shore to heed Marie-Josephte's punishment (Lacourcière, "Le triple destin" 64; Ferland and Corriveau 124). Marie-Josephte's narrative underwent several distortions over the years as villagers with first-hand knowledge of her fate recounted the events to their peers and younger

\footnotetext{
${ }^{11}$ Governor Murray erroneously calls Louis-Étienne Dodier by the name of Louis Helene Dodier. I believe this is the result of a linguistic barrier.

${ }^{12}$ Governor Murray's decision to condemn Marie-Josephte to gibbetting "showed everyone that the British were in Canada to govern, with extreme rigour if necessary" (Greenwood and Boissery 54). Indeed, in addition to the linguistic tensions experienced during the trial, the general atmosphere after the Conquest was strained. Guy Frégault argues that "in 1760 Canada was completely crushed. ... During the years 1760-3 Canada was not merely conquered and ceded to England; it was defeated. Defeat means disintegration" (14-5).
} 
generations. In the mid-nineteenth century, the legend resurfaced as an object of public discourse when scraps of an iron cage identified as La Corriveau's gibbet were found during the expansion of the Saint-Joseph-de Lévis cemetery. The legend then began to appear in literature; it was first included in Philippe Aubert de Gaspé's Les anciens Canadiens (1863) and continues to appear in contemporary works today.

Because the historical events at the origin of La Corriveau's legend occurred during the pivotal British Conquest of New France in 1760, the legend perennially embodies a symbolic site of struggle featuring key linguistic, cultural, and political tensions between French and English Canada. From its inception, the legend has been interpreted and adapted to advance both French- and English-Canadian romantic nationalist projects. Whereas de Gaspé and Louis Fréchette wrote about La Corriveau to preserve French-Canadian cultural traditions (Fréchette wrote in 1872, 1885, 1892, and 1913), James MacPherson Le Moine's and William Kirby’s works, respectively published in 1863 and 1877, incorporated the legend "to lend English Canada a measure of authenticity" (Sugars, Canadian Gothic 78). These various adaptations of La Corriveau exemplify Colin Coates and Cecilia Morgan's assertion that French-Canadian historical figures can be employed to demonstrate French-Canadian or pan-Canadian nationalist sentiments. Coates and Morgan argue that French-Canadian nationalists used historical figures "to provide evidence of the longevity of the "national' struggle" while English Canadians used the same figures to "[represent] an attempt to appropriate the past of French Canada in order to provide a longer genealogy to the Canadian nation and to imply a continuous record of progress that linked French and English Canadians" (44). Whether these figures are evidence of the longevity of French Canadians' national 
struggle or an appropriation that provides English Canadians with a longer genealogy, both cases seek to claim their respective people's longstanding presence on the Canadian landscape in ways that neglect their colonial roles vis-à-vis Indigenous peoples.

With the Quiet Revolution and the rise of Québec's national consciousness in the 1960s, Québécois writers recuperated La Corriveau as a symbol of resistance against both English Canada and institutionalized patriarchy. In this second wave of literary production concerning the legend, "les discours nationalistes et féministes redécouvrent la femme canadienne-française derrière le masque désuet de la sorcière diabolique. Désormais, 'la Corriveau' brandit un drapeau ou lève le poing. Elle devient la victime emblématique de l'oppression britannique d'un côté et de la domination patriarcale de l'autre" (Gagnon 16). ${ }^{13}$ The function of the legend among francophones therefore evolved from enriching French-Canadian culture in the nineteenth century to symbolizing Québécois ideologies of nationalism and feminism in the second half of the twentieth century. Consequently, the Commission's desire to appropriate and repurpose $\mathrm{La}$ Corriveau as a dramatic ballet for the centennial celebrations contradicts the anti-colonial Québécois version of the 1960s; the centennial's inclusion of the legend of La Corriveau in its celebrations is arguably another attempt to absorb it into the pan-Canadian identity. In this manner, this English-Canadian project resembles that of the nineteenth century wherein English-Canadian writers "began to see in French Canada a source of resonant cultural material" and "French Canada suddenly became used as a springboard for meditations on Canadian identity" (Sugars, Canadian Gothic 77). English Canada's use

\footnotetext{
${ }^{13}$ Nationalist and feminist discourses rediscover the French-Canadian woman behind the outdated mask of the diabolical witch. Henceforth, 'La Corriveau' waves a flag or raises a fist. She becomes the emblematic victim of British oppression on the one hand, and of patriarchal domination on the other.
} 
of folklore, even if it seems to promote cultural difference on the surface, is a means of controlling and containing manifestations of culture-Québec's culture, in this case. As a result, the conflicting anti-colonial Québécois Corriveau and pan-Canadian centennial Corriveau epitomize the enduring tug of war between English and French Canadians to claim the legend of La Corriveau for their respective nationalist ventures.

Tellingly, the final product of the commissioned ballet does not seem fully committed to unifying the Canadian nation since its lyrics draw on a historical point of tension between English and French Canadians. This is especially apparent in Vigneault's lyrics:

C'était du temps que tout ce pays

Était trahi envahi conquis

L’Anglais vainqueur était maître et roi

Était juge et faisait loi. (Vigneault qtd. in Le Risbé 106) ${ }^{14}$

These lines point to the country's betrayal, invasion, and conquest by the English, as well as the latter's subsequent reign over the territory. Through his songs, Vigneault and other chansonniers “sont devenus, sans le vouloir, les porte-parole d'un pays qui aspire à son affirmation, à la liberté; ils sont devenus le témoin et la conscience d'une société aux prises avec ses énormes difficultés d'être" (Bruno Roy qtd. in Le Risbé 105). ${ }^{15}$ Michèle Le Risbé even argues that “c'est en particulier à travers des chansons comme 'La Corriveau,' où cette aliénation coloniale est dénoncée, qu'une nouvelle prise de

\footnotetext{
${ }^{14}$ It was of the time when the whole country / was betrayed invaded conquered / the English conqueror was master and king / was judge and made the law.

${ }^{15} \mathrm{Had}$ become, without wanting to, the spokespeople of a country that aspires for affirmation, for freedom; they became the witness and conscience of a society suffering from great difficulties of being.
} 
conscience se manifeste (105). ${ }^{16}$ The music is similarly politicized as "the composer's strong patriotic sentiments are evident in his use of Canadian and indigenous folksong and folklore (From Sea to Sea, La Corriveau, Indian Legends)" (King and Potvin). As such, the ballet is evidence of the ambivalence about the pan-Canadian project as it attempts to capture the essence of a Québécois narrative while contributing to the creation of a monolithic Canadian identity.

\subsection{Romantic Nationalism and the Metaphors of Nation in English Canada and Québec}

La Corriveau's history as a figure of conflict between Québec and English Canada develops alongside, and in conversation with, several other key metaphors that attempt to represent and regulate the place of Québec in Canada to advance an English-Canadian romantic nationalist project. In his foundational essay on nationhood, 'Qu'est-ce qu'une nation?," Ernest Renan examines the unifying characteristics of a nation state. He rejects race, language, religion, communities of interest, and geography as unifying elements, offering instead the idea that "une nation est une âme, un principe spirituel" with two major constituents — the past and the present (Renan 26). ${ }^{17}$ The past "est la possession en commun d'un riche legs de souvenirs" whereas the present "est le consentement actuel, le désir de vivre ensemble, la volonté de continuer à faire valoir l'héritage qu'on a reçu

\footnotetext{
${ }^{16}$ It is particularly through songs like 'La Corriveau,' wherein this colonial alienation is denounced, that a new awareness is manifested.

17 "A nation is a soul, a spiritual principle" (19, translated by Martin Thom).
} 
indivis" (Renan 26). ${ }^{18}$ However, among the many problems with Canada's "soul" is its complex and divided history of settler colonialism. As a result, it is difficult to find a unified Canadian past and present. Adam Carter contends, "romantic nationalism, with its attendant assumptions about the nature and function of a national culture, has long found an uneasy ground in Canada and yet persists as an enduring ideal" (47). He argues that "the concept of a unified national character formed over centuries in an intimate, primordial relationship to place has always risked ringing false in a country populated to a great extent through colonization and settlement," mainly from France and Britain, and then through immigration from various parts of the world (Carter 47). Whereas a nation ought to be united by “un passé héroïque” with “des sacrifices qu'on a consentis, des maux qu'on a soufferts" (Renan 26-27), Canada "casts no heroic shadows because our bland, practical citizens lack the historical traumas and the responsive imagination to expose the dreams on which the nation was built" (Kertzer 37). ${ }^{19}$

One way to create the illusion of a unified national character is by controlling the national metanarrative so that it "encourages diversity but insists on homogeneity" (Kertzer 8). Jonathan Kertzer argues that while a nation is not a literal family structure, it is often represented in terms of metaphors of kinship. He claims that "nationalism imposes the homogeneity of family resemblance. Countries are expected to share a domestic language, religion, culture, or race. Any variance from the norm becomes a threat to their integrity. Purity then becomes a prime value ... an ideological imperative, a

\footnotetext{
18 "Is the possession in common of a rich legacy of memories ... is present-day consent, the desire to live together, the will to perpetuate the value of the heritage that one has received in an undivided form" (19, translated by Martin Thom).

19 "A heroic past ... the sacrifices to which one has consented, and in proportion to the ills that one has suffered" (19, translated by Martin Thom).
} 
way of thinking through exclusion" (Kertzer 9). Over the centuries, English Canada has drawn on a few key metaphors of kinship that scrupulously managed any threat to its presupposed ideological purity, and the figure of the woman necessarily became the basis for the allegorical assertion of heteronormative relationships between nations. In regard to Canada-Québec relations, Canada is often imagined as a powerful husband to a dependent and feminized Québec. In their respective studies of eighteenth- and nineteenth-century Canadian literature, scholars Pam Perkins and Carl Murphy both remark on the conventionally feminized representation of French Canadians. Perkins explains that "by transferring qualities associated with women to an entire culture, writers [like Frances Brooke] also implicitly transfer assumptions about the supposedly necessary governance of women by men to discussions of British rule over other nations" (158). This feminized representation is well-suited for "metaphors of courtship and romance," and especially companionate marriage (Perkins 159). Murphy pursues a similar project with texts from the following century. Whereas Perkins broadly surveys figures of colonization through a postcolonial lens, Murphy provides a specific conclusion on the subject of marriage metaphors. He writes that "Frances Brooke's preoccupation with marriage anticipates a central metaphor of English-Canadian writers in the nineteenth century" who will subsequently and frequently depict "Canada as a happy marriage of French and English who have freely chosen each other” (Murphy). Although the relationship between French and English Canadians results in happiness, Murphy acknowledges the struggles involved before and during the marriage, struggles which are thereafter given a teleological "happy ending" by the romance/marriage plot. 
These difficulties become central to the marriage metaphor in the twentieth century. Elspeth Probyn asserts in an oft-cited passage that "the gendering of Québec and Canada as a couple in the throes of divorce is by now so common that it needs little explanation. It comes as no surprise that once again Québec is posed as marginal to and different from Canada and that this difference is then embodied in the wife" (81). In his essay "Le corps mystique" (1964), Hubert Aquin even enumerates eight different ways in which the marital relationship between Québec and Canada was portrayed in the 1960s. One such portrayal is the "forced marriage" wherein the Canadian husband proposes to Québec for the sake of economic interests, and the Québécois wife is confined to this marriage because she does not possess economic power (Aquin, Blocs erratiques 121). The image of the Québécois wife, and more generally speaking the metaphors of courtship and romance imposed by English Canada onto the Québécois people, were challenged during moments charged with high nationalist sentiments. Québécois nationalists began to resist these oppressive articulations of nationhood in rhetorics of feminist resistance that queered heteronormative images or used tropes of divorce.

Alternatively, "where unequal relations are involved, metaphors of parents and children come into play" (Mackic 83). Examples include mother Britannia and her colonies, and unsurprisingly, Québec's infantilization with respect to Canada. In describing his own educational experience involving English-Canadian textbooks, Daniel Francis affirms that "English-speaking Canadians were educated to imagine the Québecois [sic] as a picturesque, fun-loving, and inferior minority who wanted only to be left alone to breed huge families and speak their own particular brand of patois" (96, italics in original). Moreover, "the infantilization of the Québecois [sic] by English 
Canadians went far beyond the pages of schoolbooks. The patronizing version of Quebec history and society inherited from Francis Parkman and his successors burrowed deep into the unconscious where it coloured all English impressions of Québecois [sic] culture for generations" (Francis 97).

Contrasting the marriage metaphor as an external representation that English Canadians imposed onto the Québécois nation, the trope of illness is an internal representation that originates from within Québec. In addition to Québec's national representation in ideologically inflected discourse as weak and feminine, Québec is also afflicted with illness. What makes the metaphors of kinship and marriage possible is the fundamental conceptualization of the national body as a corporeal body. If, as Kertzer argues, English Canada wishes to preserve ideological purity, then "ideological deviation was medicalized as a perversity that endangered both the individual and the entire social body" (Starks 24). Although Tricia Starks's commentary concerns the Soviet context of the 1920s, she also observes that "corporeal metaphors, used since ancient times to describe the health of a society, became a mainstay of the social sciences in the nineteenth century, with the organic nature of the state the dominant metaphor" (24). Depictions of corporeal metaphors contrast the ill body with the healthy one. Starks maintains that the health of the entire society is dependent on the health of its individuals. Consequently, "anti-social behavior became an assault on the social body. ... Once diagnosed and identified, malignant individuals could be singled out, treated, forced into compliance, or excised" (Starks 24). While the illness metaphor is arguably applicable to all nations in duress, Richard Handler and Julie Robert both make the case that it is inherent to the Québécois condition. Handler draws on two basic metaphors in describing 
what he calls the positive vision of national affirmation: first, the metaphor of the collective individual, and second, that of "the national species equat[ing] individual and group" (46-47). These relationships between individual and collective, Handler asserts, make of the Québécois nation a natural entity that is subject to biological and natural traits, and that such positive vision "is invariably accompanied by a 'negative vision' of assimilation and death" (47). He maintains that

Québécois nationalists fear the political, economic, and cultural pressure that notQuebec [France, Great Britain, English Canada, and the United States] can exert. Concern for this overwhelming influence is a theme so prevalent in nationalist discourse that one can speak without exaggeration of a pervasive fear of pollution and contamination - metaphors frequently used by the nationalists themselves. Thus we find a negative vision of national disintegration and death inevitably accompanying the positive vision of national affirmation. (Handler 47)

Therefore, this kind of contamination stands for threatening external factors that may result in the assimilation or death of the Québécois nation.

In contrast, Robert's reading of the nation as body situates the fear of pollution and contamination within the nation itself. She interprets pollution and contamination as illnesses. Framing her monograph Curative Illnesses: Medico-National Allegory in Québécois Fiction is the assertion that "Quebec adopted the pathological as a defining trait of its self-representations" (Robert 3). She traces the evolution of the mediconational allegory in Québécois fiction from the nation as a sick body "to its nationforming discourses as self-disrupting processes that trouble the assertion that Quebec is a sick nation" (Robert 17). Emerging with realist fiction in the 1940s, narratives of illness 
suggested that the Québécois nation was unhealthy, afflicted as a result of "uncertainty over collective identity and unprecedented social transformation" (Robert 3). With the Quiet Revolution, nationalists began interpreting "the statelessness of [the] nation [a]s a pathology that must be remedied in order for full national health to be achieved" in the following decades (Robert 6). Finally, contemporary works reconceptualize "earlier illness narratives as nationally therapeutic texts" (Robert 19). In other words, illness narratives become counternarratives presenting transformative and poignant battles against illnesses and self-representations of a sick nation.

Scholars perceive various iterations of the Québec-as-wife or Québec-as-sicknation as emblematic national metaphors of Québec, but such metaphors are not specific to Québec as they are also used to emblematize other nations in duress. ${ }^{20}$ Whereas they provide a glimpse of the critical applications of universal tropes in a Québécois context, tropes that are specific to Québécois nationalism are more difficult to pinpoint. There is no denying that "the Quiet Revolution ... articulated a significant transformation taking place in Québec's national self-image. One of its most prominent and enduring symbols was the reformulation of Francophone national identity: this identity shifted from French Canadian ... to Québécois" (Helfield 12). According to Gillian Helfield, the Québécois

\footnotetext{
${ }^{20}$ Jaspal Kaur Singh argues that "nationalism in colonized countries constructed its oppositional rhetoric around the figure of the woman" (35), specifically a feminine figure who requires "paternal governance" (McLuskie and Innes qtd. in Singh 6). For example, with respect to South Korean and Japanese relations, "in South Korea the 'comfort women' issue has been cast as an emblem of a nationalistic discourse in the trope of a violated and colonized victim" (Choi 13). On the subject of tropes of illness, Susan Sontag asserts that diseases have often been associated with totalitarian movements. She writes, "the melodramatics of the disease metaphor in modern political discourse assume a punitive notion: of the disease not as a punishment but as a sign of evil, something to be punished" (Sontag 82). Such disease imagery has been used by the Nazis to describe someone of mixed racial origin as syphilitic or cancerous, emblematize Bolshevism and Trotsky, or equate Stalinism to "a cholera, a syphilis, and a cancer" (Sontag 82). Thus, the trope of illness often epitomizes a fear of contamination in various political contexts, whether the threat is internal or external.
} 
identity is in itself a symbol of Québec. This national self-image is expressed in the use of a subjective first-person narration rather than an omniscient third-person one, and in the use of joual (Helfield 12). Understandably, joual, or the theme of language more broadly speaking, reappears as a recurring expression of Québécois identity and nationalism. Thomas E. Tausky asserts that "the dominance of ultramontane Catholicism and the consciousness of the need to protect a vulnerable language were the two characteristics that most profoundly divided Québec nationalism of the time from much more variegated strands of English Canadian national feeling" (797). In contrast to the dual expression of language and religion, Sean Mills suggests an evolving relationship between these two concepts. He argues that the emergence of a new Québécois identity resulting from the Quiet Revolution is one that is "centred on territory and language rather than on religion and ethnicity" (Mills 19). Language, religion, as well as land (with the popular roman du terroir), thus thematize Québécois identity.

While it is possible to trace the evolution of these themes, they are particularly salient at specific moments in Québécois literary history. For example, le roman de la terre permeated Québécois writing in the late-nineteenth and early-twentieth centuries (Gerson, "Terrien Romance" 1096), whereas joual first appeared in Québécois theatre in the late 1960s, became central in the 1970s, and then faded in the following decade (Ladouceur 34-35). ${ }^{21}$ The legend of La Corriveau is neither a universal trope nor a time-

\footnotetext{
${ }^{21}$ Louise Ladouceur asserts that “c'est en 1968, avec l'appui du Centre d'essai des auteurs dramatiques, qui est créée au Théâtre du Rideau Vert la pièce de Michel Tremblay Les belles-sœurs, qui suscitera beaucoup de controverse avant de réussir à imposer le joual comme langue de scène au Québec" [It's in 1968 that, with the support of the Centre d'essai des auteurs dramatiques, Michel Tremblay's play Les belles-soeurs was created at the Rideau Vert and generated much controversy before succeeding to establish joual as the language of the Québécois scene (33).
} 
sensitive Québécois theme, but a Québécois folkloric figure that engages with, and participates in, these two types of national discourse. It is directly tied to Québécois history while also embodying a drama of oppression, criminality, violence, resistance, gender, and so on. The legend of La Corriveau has endured and evolved over the centuries, and is continuously being shaped by the changing sociopolitical landscape of Québec.

\subsection{Examining the Legend's Role in French-Canadian Nationalism}

My dissertation examines La Corriveau as a figure that expresses and mediates conflicts between English and French Canada in both literary traditions. This folkloric tale continues to surface during momentous changes in the English-Canadian and Québécois cultural and sociopolitical landscapes (e.g., Canada's Centennial Celebrations, Québec's Quiet Revolution beginning in the 1960s, as well as its First and Second Referenda), and has gained critical attention since the $250^{\text {th }}$ anniversary of MarieJosephte Corriveau's death in 2013. Reading francophone and anglophone adaptations of La Corriveau by writers like de Gaspé, Kirby, Victor-Lévy Beaulieu, Anne Hébert, Douglas Glover, and Sébastien Chartrand through intertextual and interlingual lenses, I analyze how such a legend and its reinterpretations are reworked mainly by both FrancoQuébécois and English-Canadian authors in a desire to recuperate the figure for distinct national metanarratives in French- and English-Canadian literatures. I primarily explore La Corriveau's semantic and political functions in the construction of Québécois national metanarratives. How does it continuously evolve to signal particular shifts in the Québécois political landscape? Adjacently, I look at how it operates paradoxically as a 
key constituent and subversive component of the English-Canadian romantic nationalist project. Kertzer notes that "because the national genius blends the ideal with the actual, it readily expresses how myth informs history, how history rises into myth, and how myth in turn lapses into history. It used to be common for English Canadians to lament that somehow they had no history or myth" (55). How does the legend of La Corriveau, which inherently embodies both history and myth, then inform the English-Canadian national metanarrative?

Another important consideration is how the bicultural struggle to recreate La Corriveau for pan-Canadian or Québécois purposes has obscured the more complex ways in which the legend of La Corriveau and its various adaptations mediate the politics of nation-making in Canada. The Commission's desire to rally the Québécois people for the centennial celebrations by employing Québécois folklore and history speaks to the centennial project's overall objective, but if the legend of La Corriveau were to successfully promote a bicultural French-English country, would it not also further entrench a colonial and settler metanarrative? As Meaghan Elizabeth Beaton points out, the 1967 celebrations proved to be the perfect platform to promote the idea of a strong, united, bicultural French-English country, albeit to the detriment of other identities, cultures, and communities, including Indigenous populations. This emphasis on biculturalism, as many national centennial programs revealed, ultimately further entrenched a colonial and settler narrative of Canada's history.

Alternatively, does the failure to integrate seamlessly the figure of La Corriveau, as seen with the dramatic ballet, suggest that La Corriveau can challenge such national 
metanarrative because it cannot be incorporated successfully into the pan-Canadian project? Although the historical scholarship on La Corriveau has often focused on biculturalism (Lacourcière; Ferland and Corriveau), many primary sources place the figure in conversation with other nations, cultures, and peoples, offering the possibility of studying the legend in conjunction with various interrelated contexts including English Canada, indigeneity, and globalization. Taking our cue from these primary works, we might ask: what does this figure tell us about national figures of Québec in the contemporary period? As a gothicized figure of otherness, does La Corriveau serve as "a counternarrative intended to undo the inherited binary conception of Canadian society, a counternarrative that should be read alongside the master narrative of the nation" (Kamboureli, Scandalous Bodies 93)? Or has it been subsumed into this master narrative? These questions are the driving force of this dissertation.

\subsection{Examining the Legend's Sociopolitical Functions in National Frameworks}

Scholarship on the legend of La Corriveau has mostly taken historical and encyclopedic approaches. In the 1940s, an individual named Joseph-Eugène Corriveau was tired of having a tainted patronym and initiated archival research in hope of establishing accurate facts relating to Marie-Josephte Corriveau. He died a few months after finding the necessary documents (December 3, 1947) and Lacourcière subsequently continued the project. Lacourcière sought to separate fact from fiction; he provided "truth" and "facts" about Marie-Josephte Corriveau's life and historical context, and showed the various ways in which oral tradition distorted the legend. His first essay, "Le triple destin de Marie-Josephte Corriveau (1733-1763)" published in 1968, provides an 
overview of Marie-Josephte's life and a detailed account of her two trials. His second essay, "Le destin posthume de la Corriveau" published the following year, examines the historical event's transformation into an oral legend after Marie-Josephte's death. Subsequently, Lacourcière attempted to "suivre à travers tous les textes écrits des conteurs, romanciers, chroniqueurs et historiens [jusqu'à l'année 1947], le destin posthume de la Corriveau" with a particular emphasis on Les anciens Canadiens ("Le destin posthume" 99). ${ }^{22}$ His final essay, "Présence de la Corriveau," was published in 1973 and studies the legend's continuous presence in written texts, oral adaptations, and arts from 1947 to the early 1970s. Lacourcière's three essays are now bound and edited in Bertrand Bergeron and Jean-Pierre Pichette's La Corriveau : la formation d'une légende (2017). With respect to the scholarship on the legend of La Corriveau, Bergeron and Pichette argue that "la lecture du maître ethnologue reste la référence obligée" (9). ${ }^{23}$

Catherine Ferland and Dave Corriveau's La Corriveau : de l'histoire à la légende (first edition in 2013, second edition in 2014) is a monograph-length study of the legend that expands on previous scholarship. Ferland and Corriveau's study examines similar material to Lacourcière's work, from Marie-Josephte's biography to the narrative's transformation into legend in oral and written cultures, and ends with an extensive survey of various artistic adaptations of the legend from its inception to 2014. The first section of their work takes a historical approach as the scholars contextualize the legend with information on the historical period, as well as information about integral aspects of the legend such as the practice of gibbetting and the confusing legal practices (British,

\footnotetext{
${ }^{22}$ Follow through all of the texts written by storytellers, novelists, chroniclers, and historians [up to the year 1947], the posthumous fate of La Corriveau.

${ }^{23}$ This masterful ethnologist remains the essential reference.
} 
French, and military) surrounding La Corriveau's trials. The second section examines the process of transformation from history to legend, including Marie-Josephte's vilification and the legend's integration into Québécois national heritage. This section also comprises the legend's appearance in media. Ferland and Corriveau take an encyclopedic approach to this subject, surveying chronologically a variety of artwork, literary works, and other media that make reference to the legend, but are not primarily concerned with disentangling the connections between the many works surveyed. Although my dissertation also draws on the historical approach, especially in tracing the figure of La Corriveau's evolution in both English-Canadian and Québécois histories, I wish to move away from the encyclopedic approach. Rather than survey all of the works dating from the nineteenth century to the present day, I focus on a selection of primary works (mostly, but not exclusively, literary) to emphasize how they engage and converse with one another in order to elucidate the legend's sociopolitical functions within the national frameworks of French and English Canada. For instance, while Lacourcière, Ferland, and Corriveau discuss the four fundamental texts of the nineteenth century, namely those of de Gaspé, Le Moine, Kirby, and Fréchette, their sequential presentation of the material obscures configurations of the legend that play an integral role in French- and EnglishCanadian romantic nationalist projects.

Ferland and Corriveau's monograph in particular serves as a critical foundation to this thesis. In the spirit of showing my intellectual indebtedness to their work, my thesis's epigraph pertaining to Vigneault's song "La Corriveau" echoes Ferland and Corriveau's use of the same song as their own epigraph. However, in attending briefly to the context of production of the dramatic ballet and song at the beginning of this introduction, as well 
as to their significance in Québécois and English-Canadian metanarratives of nationhood, I already show implicitly how my work will differ significantly from Ferland and Corriveau's study as I bring together culture, literature, politics, and history. My work is in constant dialogue with that of Ferland and Corriveau, which allowed me to discover a wide range of texts, but especially material culture such as Canada Post's Haunted Canada stamps and the beers called "La Corriveau" and "La Corriveau Impériale" produced by the Québécois microbrewery Le Bilboquet. Although I draw on the same material, my thesis departs from their study in that it brings all of these sources into conversation with one another. In line with the encyclopedic approach, for instance, Ferland and Corriveau devote two pages out of over four hundred to describing Kirby's version of the legend (219-220), three pages to Anne Hébert's La cage (279-281), and approximately one page of text to the Corriveau beers (325-326) ${ }^{24}$ By dwelling carefully on selected items pertaining to the legend and showing how they inform and respond to one another, I allow connections to emerge that would not otherwise be visible through the encyclopedic approach.

Drawing on a variety of practices including historical, political, and literary, this interdisciplinary project begins with nineteenth-century texts and then re-evaluates the evolution of the legend after the Quiet Revolution, its relevance to the current state of Québec's nationalist project, and English Canada's attempts to recuperate the figure for its own national unification. To this end, it first analyzes how the legend of La Corriveau, as a French-Canadian gothic tale, mobilizes folklore to engage in the politics of identity

\footnotetext{
${ }^{24}$ Ferland and Corriveau mention Kirby's The Golden Dog sporadically throughout their monograph. However, the encyclopedic entry proper spans two pages. The same is true for their references to Hébert and Le Bilboquet.
} 
and nationalism. Subsequently, it complicates the sociopolitical role of La Corriveau by studying how the folklore functions within national and critical frameworks of Québec and English Canada, and how it continues to be rewritten to mediate ongoing conflicts between Québécois and English-Canadian national metanarratives. My dissertation thus significantly develops the existing scholarship on the legend of La Corriveau in three main ways. The first is through its historiographical approach to the subject. In the preface to his edited collection of essays on the historiography of the British Empire, Robin W. Winks astutely defines historiography as "an adventure in the history of ideas, the study of how a subject has been written about, how trends and interests in research have changed, how public events, world affairs, and so simple a matter as the opening of an archive shapes the way in which writers explore the past" (xiii). More importantly, "historiography is also about how and why people have come to comprehend themselves in a certain way. Historiography is thus more than the record of what has been written. It is also the examination of why a body of writing has taken the shape it has" (Winks xiii). Whereas Lacourcière, Ferland, and Corriveau have brilliantly examined the history behind La Corriveau as a legend and as a historical figure, I seek to study the historiography of La Corriveau to understand how this legend has shaped Québécois identity, Canadian identity, and the two nations' perceptions of self and other. My study is thus reflexive and attentive to the politics of representation (even as these are present in historical discourse) in a way that the other studies are not.

Secondly, my project extends the temporal scope of current scholarship. In addition to re-examining some of the pillar texts of the nineteenth century on the legend of La Corriveau, I analyze the legend's ongoing and shifting role through a variety of 
more contemporary francophone and anglophone works such as Glover's "La Corriveau" (1993), Jean Beaudin's film Nouvelle-France (2004), Sébastien Chartrand's Le crépuscule des arcanes (2013-2016), Gene Lessard's An Object of Conviction: A Compelling Story of a Conquered People, Social Injustice, and Family Tragedy (2016), and David Ménard's Poupée de rouille (2018) to understand how major changes on the English-Canadian and Québécois sociopolitical fronts at the end of the twentieth and beginning of the twenty-first centuries have continued to shape the legend of La Corriveau's ideological functions.

The third way in which I significantly develop the scholarship on the legend of La Corriveau is through my application of a comparative approach. In bringing together anglophone and francophone texts featuring the legend of La Corriveau, my dissertation is inherently comparative in nature as it shows how the eponymous figure moves between English-Canadian and Québécois representations. In other words, it is a comparative study of how La Corriveau is semantically very complex; the figure is constantly revised as it alludes to earlier historical moments in which it was active. For the type of comparative study I wish to perform here, E.D. Blodgett's statement rings true: "at first glance it would seem that the phrase, 'comparative Canadian literature,' would be simple enough to define. It is not, however, so easy" (Configuration 13). While comparative Canadian studies in the late 1980s showed "only one dominant consideration ... which [wa]s the relationship between the anglophone and the francophone literatures of Canada" (Blodgett, "Canadian Literature" 905), comparatists have since moved away from this binary approach. Kristy McKay affirms that scholars such as Clément Moisan and Blodgett attempted to transcend this binary by the end of their respective careers, but 
also recognizes that "a primary source of paradox that has stood in the way of some early comparisons is the assumption that on the basis of Canada's unity of statehood, the literatures produced here should be similarly unified" (19). Cynthia Sugars makes a similar claim concerning the binary framework's reproduction of Canada's false unity, asserting that "despite attempts to emphasize the distinctness of the two language groups, the bicultural approach as articulated by [Philip] Stratford has been accused of being still too unifying, for it continues to conceive of a vaguely homogeneous nation with two separable literatures" (“On the Rungs” 6).

In response to this quandary, McKay argues that "translation emerges as a promising component to comparative Canadian literature in the twenty-first century" (19), as exemplified in the works of Sylvia Söderlind, Peter Dickinson, and Sherry Simon. Translation, in this instance, does not refer to the linguistic adaptation from one language to another, but to cultural translation. Ovidi Carbonell Cortés and Sue-Ann Harding note the recent cultural change in the field of translation studies. They argue that "far from being simply a matter of contrastive linguistics, translation is now regarded as a complex interlinguistic and intercultural process where the context of communication is of foremost importance" (Cortés and Harding 1). Söderlind's Margin/Alias: Language and Colonization in Canadian and Québécois Fiction (1991), which explores translation and negotiation between two languages, is one example of this shift. In a book review, Laurie Ricou explains that Söderlind's work does not seek to represent a homogenized Canadian identity through her analyses of Canadian and Québécois works in comparison. Instead, she recognizes the cultural differences existing in the two literatures (4). 
Dickinson provides a more precise definition of translation and offers a glimpse of its hopeful possibilities in the field of comparative Canadian studies. He writes, if we conceive of translation as an indeterminate and ongoing system of structural, linguistic, cultural, historical, and so on, transformations, borrowings, and mediations that occur between and across forms, and if we further examine what these transformations say about the historical context in which texts are produced and received, then translation's critical potential, as applied to the adaptive process, is, I believe, recuperable. (Dickinson 34)

In Here is Queer: Nationalisms, Sexualities, and the Literatures of Canada (1999), Dickinson's reading of nationalism as it intersects with sexuality, gender, ethnicity, and race disrupts the binationalism that previously characterized comparative work on Canadian literature. Other comparatists share Dickinson's use of translation as an approach to comparative Canadian studies.

Sherry Simon's Le trafic des langues : traduction et culture dans la littérature québécoise (1994) is yet another example of how translation operates in a comparative context. Simon acknowledges that translation is traditionally considered "une opération de transmission d'un texte, écrit dans une langue, appartenant à une culture, vers une nouvelle demeure linguistico-culturelle" (181). ${ }^{25}$ Challenging this notion, she asks, "que se passe-t-il si les langues et les cultures 'de départ' se révèlent déjà plurielles? Alors il faut reconceptualiser la traduction pour y voir une opération qui n'aboutit pas toujours à un résultat homogène mais qui-à l'instar des identités culturelles du monde

\footnotetext{
${ }^{25}$ An operation of transmission from one text, written in one language, belonging to one culture, toward a new linguistic and cultural dwelling.
} 
contemporain — se confronte en permanence à l'inachevé" (Simon 181). ${ }^{26}$ These various conceptualizations of translation demonstrate the concept's malleability and the many ways in which it may transcend the French- and English-Canadian linguistic and cultural borders that previously restricted comparative Canadian studies.

Translation allows me to engage in a "processus de négociation interlinguistique et interculturelle" (Simon 181) by drawing on theoretical approaches and literary movements that rarely intersect due to cultural or linguistic barriers, and to bring them in an exchange that informs both Québécois and English-Canadian literary and theoretical spheres. ${ }^{27}$ This translative approach to comparative studies allows me to circumvent the aforementioned facile trap of studying the legend of La Corriveau in a binary framework. By “center[ing] on the ways that Québécois and English-Canadian writers have inhabited space: the territories of reality, the imagination and language" ("Our Two Cultures" 18, italics in original), as Patricia Smart suggests, as well as by examining the various, multilayered ways in which both Québécois and English-Canadian discourses intersect with the politics of indigeneity, settler colonialism, nationalism, and globalization, my dissertation pursues Blodgett's project of recognizing the differences that give value to the national literatures being compared.

\footnotetext{
${ }^{26}$ What happens if the initial languages and cultures are already plural? Then one needs to reconceptualize the notion of translation to conceive of an operation that does not always lead to a homogenous result but that-like the cultural identities of the contemporary world - permanently confronts that which is incomplete.

${ }^{27}$ Process of interlinguistic and intercultural negotiation.
} 


\subsection{Chapter Division}

My dissertation is divided into six chapters. Following this introductory chapter, Chapter Two traces the emergence of La Corriveau as a gothic figure of otherness within texts that advocate for English-Canadian romantic nationalism. Although this figure originates from Québec, and although it most typically represents Québec as a dangerous internal other, works inflected by English-Canadian romantic nationalism also frequently identify the threat of La Corriveau with additional national others. Foremost among these are Acadians, Scots, and Indigenous figures. In this chapter, I look at two seminal texts in French-Canadian and English-Canadian literary studies, namely de Gaspé's Les anciens Canadiens (1863) and Kirby's The Golden Dog (1877), as instances of this phenomenon. Regardless of the culture that La Corriveau embodies, the figure is destined to perish in de Gaspé's and Kirby's works because it presents a clear threat to the survival of the British officers in the New World.

In Chapter Three, I examine the second wave of literature pertaining to $\mathrm{La}$ Corriveau from the 1960 s onward with respect to the drastic shift in the folkloric material that occurred following Lacourcière's archival research on La Corriveau in the late 1940s. Beaulieu and Hébert are two well-established Québécois writers, Beaulieu being known for his novels, and Hébert for her novels, poetry, and nouvelles. Yet, both of these writers turn to theatre to explore the legend of La Corriveau. Through analyses of Beaulieu's Ma Corriveau (1973) and Hébert's La cage (1990), I examine La Corriveau's transformation from an othered figure associated with indigeneity to a nationalist and feminist symbol of French Québec. Central to these developments was the disarticulation of La Corriveau from its earlier association with Indigenous peoples, a disarticulation that 
was facilitated by the changing nature of Indigenous cultural politics in Canada and Québec at the time. With the Quiet Revolution's spur to national consciousness and a new focus on feminist consciousness evident in the development of the écriture au féminin movement in Québec, La Corriveau shed its discursive history's complicating link to indigeneity and became newly legible: not as a sinister witch or figure of otherness, but as a wrongfully accused woman who embodied Québec's oppressed condition, even as the figure challenged English-Canadian culture.

In Chapter Four, I turn to a consideration of how contemporary non-Québécois writers repurpose the legend of La Corriveau; in their works, the figure is no longer strictly a symbol of Québec nationalism and feminism, but a more flexible and often personal signifier within the writers' various projects of cultural satire, revisionist biofiction, and religious poetry. Drawing on and combining multiple periods of $\mathrm{La}$ Corriveau's discursive history, the works considered in this chapter revise the appropriative cultural nationalism of English Canada (discussed in Chapter Two) in light of the Québécois reappropriation of La Corriveau for feminist and cultural nationalist politics (discussed in Chapter Three). My critical examination of Glover's “La Corriveau" (1993), for instance, demonstrates how this English-Canadian writer complicates a tradition of Anglo representations of Québec through his appropriation of the eponymous Québécois legend. In his work of life writing, the American selfpublished author Gene Lessard also glancingly employs La Corriveau as a national allegory for Québec. However, his goal is to narrate a fictionalized version of his family's history that redeems his notorious ancestor, not to engage in Québec-Canada politics. Indeed, Lessard's ancestral ties to Marie-Josephte Corriveau are what lead to his re- 
imagining of the historical events in the novel An Object of Conviction: A Compelling Story of a Conquered People, Social Injustice, and Family Tragedy (2016) in the first place. Ménard's Franco-Ontarian prose poetry collection Poupée de rouille (2018), meanwhile, moves even further away from questions of nationhood. Ménard reverses the malevolent image of Marie-Josephte, recuperating her as a figure of benevolence. Creating a story based on love and self-sacrifice, he significantly revises the legend by positioning it within the context of religion and by ignoring its longstanding political and historical tensions.

Chapter Five explores the gradual commodification of the legend of La Corriveau from Québec's Second Referendum in 1995 onward in contemporary cultural and material productions of La Corriveau's folklore in Québec and Canada. In this chapter I demonstrate that the downplaying of La Corriveau's affiliation with feminism and nationalism (discussed in Chapter Four) coincides with Québec's increasing turn away from the sovereignty movement. Whereas the first wave of literature relating to the legend of La Corriveau antiquarianized the narrative to preserve a rich part of FrenchCanadian culture, and the second wave politicized the figure in light of the emergence of Québécois national consciousness, this third stage of production returns to antiquarianizing La Corriveau while simultaneously bringing this Québécois story into conversation with other cultures, legends, and histories. I examine three such instances of commodified antiquarianization: a series of stamps called Haunted Canada that features one of La Corriveau; La Corriveau's gibbet and its display in an exhibition called "Sortir de sa réserve : 400 objets d'émotion" at the Musée de la civilisation in Québec City; and two beers called "La Corriveau" and "La Corriveau Impériale" produced by the 
microbrewery Le Bilboquet in Saint-Hyacinthe, QC. These diverse objects, I suggest, mediate the perception of Québécois culture as they are produced and distributed inside and outside Canada.

I conclude my dissertation with Chapter Six, which revisits the politics of Indigenous representation with respect to the figure of La Corriveau and argues that her legend continues to be haunted by its history of associations with Indigenous peoples in the contemporary period. Beaudin's Québécois film Nouvelle-France (2004) offers an uncritical presentation of Québec's settler colonial project for an international audience. Through La Corriveau's identification with the Innu population, the filmmakers seek to purify Québec of its colonial past, even as the figure appropriates the Indigenous peoples' position as colonized vis-à-vis English Canada. Chartrand's historical fantasy trilogy Le crépuscule des arcanes (2013-2016) provides a valuable, if only partial, counterpoint to Beaudin's film, for as I show, while attempting to reject La Corriveau's settler indigenizing role and to reflect critically on Québec's relationship with Indigenous peoples, Chartrand's work, too, ultimately upholds Québec's problematic settler colonial project. An examination of the legend of La Corriveau's reassociation with indigeneity in these works reveals a return to a nationalist project, but this time one that celebrates and attempts to justify Québécois settler nationalism. 


\section{Chapter 2: Nation Building, Legend Making}

Depictions of Marie-Josephte Corriveau as a witch and a poisoner go back, in some ways, to her lifetime. That is not to say that she was an actual practitioner of the dark arts, but her villainous portrayal stems from the ways in which the inhabitants of Saint-Vallier de Bellechasse viewed her before her execution in 1763. They considered her a social deviant because of her "écart par rapport aux diktats sociaux et aux attentes d'une société largement patriarcale" (Ferland and Corriveau 198), and she was therefore akin to "les meurtriers, criminels, sorciers et mécréants [qui] demeurent figés dans les marges" when the problem of deviance remained unresolved (Jean Du Berger qtd. in Ferland and Corriveau 201). ${ }^{28}$ These perceptions of Marie-Josephte play a key role in the subsequent recognition of the legend of La Corriveau as an inherently gothic folkloric tale. As CBC mediatized it in 2013, "the sound of her cage rattling in the wind and creaking as it swung from a tree became the foundation of a ghost story still told today" (“Cage of La Corriveau on Display in Lévis").

Marie-Josephte's popular association with criminality and villainy was the result of a series of lurid events that occurred during and soon after her lifetime. When the legend of La Corriveau transitioned from oral to written tradition in the second half of the nineteenth century, this link between La Corriveau and criminality naturally facilitated the figure's transformation into a gothic being in the first literary texts featuring the legend. Since its emergence in the eighteenth century, gothic fiction has been a genre closely linked to sociocultural issues of its authors' time but also to the unfinished

\footnotetext{
${ }^{28}$ Deviation from social norms and the expectations of a largely patriarchal society ... the murderers, criminals, sorcerers, and miscreants [who] remain fixed in the margins.
} 
business of the past. Core gothic tropes like antiquated spaces and gothic monstersespecially ghosts - inherently referred contemporary anxieties to social or historical plights that continued to haunt the present. The concerns and fears of the gothic are culturally specific, and naturally evolve over time to mirror the history of the nation in question. The British gothic that originated with Horace Walpole's The Castle of Otranto (1764) and that was further developed by authors including Clara Reeve, Matthew Gregory Lewis, Ann Radcliffe, Mary Shelley, and Edgar Allan Poe (Greene 443) evolved into a multitude of subgenres. Imperial gothic, for instance, is concerned with "anxieties about the ease with which civilisation can revert to barbarism or savagery and thus about the weakening of Britain's imperial hegemony" (Brantlinger 229). Furthermore, it "balances the imperialist's cultural place of origin with the alien environment that that culture aspires to conquer, control, reshape, and exploit" (Hughes 141). On the other hand, Louis S. Gross claims that "there is a more central position for the Gothic in American fiction than in any other national literature" because of its effectiveness in expressing American culture (2). Indeed, American writers draw on the gothic to capture their nation's various conditions from the frontier experience "with its inherent solitude and potential violence," to "racial issues concerning both slavery and the Native Americans" (Lloyd-Smith 4).

These examples serve to demonstrate that every national variation or subgenre of the gothic produces a new "villain" or evil that must be conquered based on the metanarrative of said nation. More importantly, this villain is othered — a term coined by Gayatri Spivak that "refers to the social and/or psychological ways in which one group excludes or marginalizes another group ... the other is the excluded or 'mastered' subject 
created by the discourse of power" (Ashcroft et al. 188). Tabish Khair rightly notes that "otherness is a central concern of Gothic literature in general" (4). The figure of otherness is most often the antagonist to a white, bourgeois, heterosexual norm and appears "at times when the desired certainty of this standard was being called into question by rapid changes" (Wester 157). The figures of otherness at play in nineteenthcentury English-Canadian gothic fiction were therefore most typically those obstructing national unity internally: French Canadians and Indigenous peoples.

Les anciens Canadiens (1863) and The Golden Dog (1877) are two literary works that present French Canada as an internal other that needs to be managed since English Canada did not simply assimilate French Canadians into a homogenous, unified nation. As Eva Mackey asserts, “the idea of 'flexible strategies' used within broader Western projects, helps to account not only for the erasures but also the inclusions in discourses of Canadian identity. In this framework, the construction of culture and difference, and not simply its erasure, is an integral part of flexible Western projects, practices and procedures" (30). Based on the way Canada wished to present itself in relation to the United States at various historical moments, it would downplay or emphasize its French cultural differences. Indeed, "French cultural differences were sometimes erased" when Canada wanted to define itself as a homogeneous nation to contrast the heterogeneous United States (Mackey 45). At other moments, conversely, "the French presence was made paramount, to mark difference from the USA," on the grounds that "Canada allowed the retention of local traditions and heterogeneity, unlike the homogeneous USA" (Mackey 45, italics in original). The tolerance of such traditions was especially possible during moments when English Canadians were certain that French Canadians 
posed no threat to the political balance due to their apparent demographic decline (Mackey 45). As Carl Berger notes, "the influence of the French was inexorably decreasing" at the end of the nineteenth century and beginning of the early twentieth century (146). Thus, by treating French Canada as an internal other rather than erasing any sign of French culture, English Canada was able to manipulate it in order to create a desired and advantageously flexible self-image. The same can be said about the various internal others such as the Indigenous peoples who challenged the national, monolithic image of English Canada.

In this chapter, I trace the emergence of the legend of La Corriveau from the circumstances of Marie-Josephte's death to the crystallization of the figure in nineteenthcentury literature alongside French- and English-Canadian romantic nationalisms. The chapter begins with a brief overview of the time spanning between Marie-Josephte's death and her first appearances in literary works. Subsequently, it takes a step back and macroscopically explores the development of French- and English-Canadian strands of romantic nationalism. I then bring legend and nationalism together by examining the legend of La Corriveau's relevance and function as a folkloric tale within the framework of romantic nationalism. Specifically, I show how de Gaspé and Kirby respectively repurpose the legend of La Corriveau in support of English-Canadian ascendency following the Conquest of 1760 by exploiting the legend's gothic mode. Les anciens Canadiens and The Golden Dog demonstrate the functional complexity of the legend of La Corriveau as they bring together a variety of internal others that must be subsumed in the creation of a monolithic English-Canadian identity. While de Gaspé's novel explicitly supports French-Canadian romantic nationalism, his Corriveau figure's association with 
the sorcerers on the Île d'Orléans is an implicit, metaphoric call for the French-Canadian aristocracy to support British officers in their quest to dominate New France in order to conserve the former's place at the top of the hierarchy in the new social order following the Conquest of 1760. In turn, The Golden Dog promotes English-Canadian romantic nationalism without qualification as Kirby's Corriveau figure engenders the erasure of threatening, internal others and facilitates the "peaceful" assimilation of French Canadians into the British Empire following the Conquest. In that sense, the figure of La Corriveau becomes what scholars such as Mackey call a flexible strategy as it erases and includes French Canadians in discourses of English-Canadian identity.

\subsection{Marie-Josephte's Vilification: Crystallizing Her Infamy}

Marie-Josephte's association with malevolence and unruliness can be traced back to the rumours that derived from her short-lived second marriage. Her decision to marry Dodier, a bachelor who was younger than her, after a year and a half of widowhood, was most likely disapproved of by her fellow villagers. Ferland and Corriveau posit that "s'il n'est pas possible de déterminer avec certitude que le mariage de Marie-Josephte Corriveau et Louis Dodier est effectivement marqué par un charivari ou une autre forme de désapprobation populaire, cela demeure probable puisque cette pratique est bien attestée pendant cette période" (68). ${ }^{29}$ Dodier's sudden death further tarnished MarieJosephte's reputation and added to the controversy surrounding her decision to marry

\footnotetext{
${ }^{29}$ If it is not possible to determine with certainty that the marriage between Marie-Josephte Corriveau and Louis Dodier was, in fact, marked by a shivaree or another form of popular disapproval, it still remains probable since this practice was well attested during this period. In this context, the French term "charivari" - or shivaree in English - refers to a mocking celebration with loud noises of pots and pans that symbolizes a community's opposition against a widow's remarriage.
} 
him. While villagers were convinced that Marie-Josephte's father was responsible for Dodier's death, the circumstances led some of them to speculate on whether or not Marie-Josephte had also precipitated the death of her first husband (Ferland and Corriveau 75). The fact that she was twice widowed made her suspicious in the eyes of her contemporaries.

Other detrimental rumours about her were spread in the courtroom. During the first trial against Joseph and Marie-Josephte Corriveau, Claude Dion was called to testify. He was Marie-Josephte's neighbour and claimed that Marie-Josephte often flirted with him, even implying that she was ready to have sexual intercourse with him were he to get rid of Dodier (Ferland and Corriveau 98). He asserted that Marie-Josephte was "une ivrognesse, qu'elle vend n'importe quoi pour avoir de l'alcool et qu'il lui arrivait de vomir dans les bonnets de ses enfants" (Ferland and Corriveau 98). ${ }^{30}$ This portrayal of Marie-Josephte as unruly is captured in various literary depictions, and whether writers present this portrayal as fact or false accusation in their narratives, there is no dissociating Marie-Josephte from the figure of an often inebriated temptress and murderer.

Joseph Corriveau and Isabelle Sylvain (Marie-Josephte's intellectually disabled cousin who was condemned for perjury) were exonerated of all charges. Since they were judged to be wrongfully accused and their sentences were reversed (Joseph was initially sentenced to execution and Isabelle was to be branded on the hand with a "P" for perjury and receive thirty whip lashes), it was absolutely forbidden for villagers to "faire des reproches à Joseph Corriveau et à Isabelle Sylvain au sujet des faits pour lesquels ils ont

\footnotetext{
${ }^{30}$ A drunkard, that she sold anything so that she may have alcohol, and that she sometimes vomited in her children's bonnets.
} 
été jugés"” (Lacourcière, "Le destin posthume" 70 ). ${ }^{31}$ However, "aucune restriction ne concerne Marie-Josephte Corriveau. Bien au contraire. C'est elle seule qui désormais polarisera l'anathème du jugement populaire" (Lacourcière, "Le destin posthume" 70). ${ }^{32}$ In other words, villagers were not forbidden from blaming Marie-Josephte, and she became a vilified scapegoat. After the trials and Joseph's exoneration, villagers came to believe that Joseph was his daughter's first victim; he must have been under her spell since he admitted to being Dodier's murderer. For these reasons, "la vindicte populairecar c'est ici ce qu'expriment les transformations - aura tôt fait aussi, à cause du gibet effroyable, de l'associer aux puissances infernales" (Lacourcière, "Le destin posthume" 70). ${ }^{33}$ The villagers made Marie-Josephte into a hellish fiend, and after her execution, Marie-Josephte Corriveau became even more closely associated with the "puissances infernales." It is unclear who took Marie-Josephte's body down from her gibbet and when, which subsequently led to the emergence of a plethora of rumours that her body had simply disappeared. The sole recorded date relating to the removal of the cage from the crossroads is May 25, 1763, when Governor Murray ordered Marie-Josephte's body to be taken down due to complaints about the odour of decay. ${ }^{34}$ The body's mysterious and unrecorded removal from the crossroads inspired Louis Fréchette to write in "Une

\footnotetext{
${ }^{31}$ Criticize Joseph Corriveau and Isabelle Sylvain regarding the facts for which they were judged.

${ }^{32}$ No restriction concerns Marie-Josephte Corriveau. On the contrary. She alone will henceforth be the focal point of anathema in popular judgement.

${ }^{33}$ Popular vindictiveness - because this is what these transformations express here-would soon after, due to the appalling gibbet, associate her with infernal forces.

${ }^{34}$ Ferland and Corriveau argue that Marie-Josephte's body was exposed for approximately five weeks (140), while Lacourcière claims that it was exposed for a minimum of forty days based on Murray's order ("Le triple destin" 64). Whether it was thirty-five days, forty days, or even longer, British authorities, especially Governor Murray, quickly realized they needed to avoid antagonizing the French-Canadian inhabitants as much as possible during this tumultuous period (Ferland and Corriveau 142). In addition to addressing the odour complaints, Murray hoped the removal of the cage would mark "la fin des hostilités" [the end of hostilities] following the Treaty of Paris, and prevent "la grogne populaire et de potentielles révoltes" [popular discontent and potential revolt] (Ferland and Corriveau 142).
} 
relique" (1885) that the Devil had taken the body away, thereby concretizing the association of La Corriveau with Satan himself in the development of the legend.

The first Québécois press, La Gazette de Québec/The Québec Gazette, was only founded in the year following La Corriveau's execution, meaning there was no widespread, public, and accessible record of the facts pertaining to the trials or ensuing events. Consequently, Marie-Josephte's narrative underwent several distortions over the years as villagers with first-hand knowledge of her fate recounted the events to their peers and younger generations. Because many inhabitants were illiterate, "le Bas-Canada colonial [était] alors très majoritairement une société rurale et agricole où domin[ai]ent la culture et la communication orales. La vie y [était] scandée par le calendrier saisonnier et religieux et les relations entre les hommes_la sociabilité—[étaient] profondément marquées par cette ruralité et cette oralité” (Lamonde 67). ${ }^{35}$ Approximately eighty-six years later, in the mid-nineteenth century, scraps of an iron cage identified as La Corriveau's gibbet were found during the expansion of the Saint-Joseph-de-Lévis cemetery. Louis Fréchette, "considered by many to be the 'father of French Canadian literature"” (MacDonald 397), claimed to have witnessed the exhumation of the gibbet during his childhood in 1849, which he detailed in "La cage de la Corriveau" (1885) and Originaux et détraqués (1892). ${ }^{36}$ However, de Gaspé, James MacPherson Le Moine, and historian Joseph-Edmond Roy all believed the exhumation took place in 1850, which

\footnotetext{
35 "Colonial Lower Canada was at this time a largely rural, agrarian society in which oral culture and communication dominated. Life followed the rhythm of the seasons and the religious calendar, and sociability - the social relationships among people — was deeply marked by rurality and orality" (47, translated by Phyllis Aronoff and Howard Scott).

${ }^{36}$ In contrast to this claim, Andrea Cabajsky believes that "Henri-Raymond Casgrain (1831-1904) earned the designation 'the father of French-Canadian literature' in part for his efforts to promote the recognition of Quebec literature within Quebec" ("Eighteenth-" 247).
} 
they noted respectively in Les anciens Canadiens (1863), "Marie Josephte Corriveau, A Canadian Lafarge" (1863), and the third volume of Histoire de la seigneurie de Lauzon (1900). Some newspaper articles even situated the event in 1851 (Ferland and Corriveau 166).

Despite the ambiguity surrounding the time of the discovery, this incident precipitated a resurgence of Marie-Josephte's story in the French-Canadian imagination. The exhumed gibbet was displayed in Montreal, Québec City, and eventually the United States at a time when curiosity cabinets and touring exhibitions were in vogue. When it made its way to the Barnum Museum in New York at the end of the summer in 1851, it was labelled as the "Point Levy Relic" and described as "l'instrument de torture ayant servi à punir une femme qui avait tué ses deux maris" (Ferland and Corriveau 172). ${ }^{37}$ During the museum's high season, there could be up to fifteen thousand visitors a day (Ferland and Corriveau 173). It would thus not be presumptuous to assume that this description of the gibbet helped crystallize Marie-Josephte's reputation as a murderer. Much later on September 5, 1894, there was a published letter in The Gazette claiming that "on permanent display at the Chateau de Ramezay is an iron cage in the shape of a human body, into which the ghost of 'la Corriveau' is said to materialize each Halloween" ("Relics of Two Long-Remembered Deaths Inspired Letter-Writers"). In this instance, the gibbet's narrative makes of Marie-Josephte a ghostly apparition and intrinsically connects the legend of La Corriveau to the typical ghost story.

\footnotetext{
${ }^{37}$ The instrument of torture that served to punish a woman who had killed her two husbands. In addition to the translation, I wish to point out that according to Ferland and Corriveau, after the cage was exhumed and briefly displayed in Montreal and Québec City, a man stole it and sold it to P.T. Barnum, of the eponymous Barnum Museum in New York, in order to make a substantial profit (171-72).
} 
Thus, in the century following Marie-Josephte's trial, she was vilified by the villagers who saw her as a drunk temptress and murderer, her reputation was subsequently distorted through oral tradition (she became the murderer of one, two, and sometimes even up to seven husbands), and the exhibition of her cage in museums led to her official and definitive portrayal as a murderer, one that even returns as a spectral apparition on occasion. These lasting rumours and stories were instrumental in fabricating her villainous reputation. In future literary portrayals, she would be further vilified; the figure of La Corriveau would become a demonic being, a "méchante bête, avec son crâne sans yeux ... [une] esquelette" (de Gaspé 33) or a hired assassin who "looked down upon all her sex as the filth of creation ... [with] a deep grudge against mankind, and a secret pleasure in the misfortunes of others" (Kirby 366). ${ }^{38}$

\subsection{Transformations in the Legend and French-Canadian Nationalism}

During the time of the cage's exhibition as an object of wonder and curiosity in New York and subsequently in Boston, the legend of La Corriveau was moving from oral tradition to literary form in the Province of Québec. ${ }^{39}$ Just as the cage descriptions associated Marie-Josephte with criminality, the literary narratives performed a similar function. De Gaspé was the first person to include the legend of La Corriveau in his writing. His courtes nouvelles "Une nuit avec les sorciers" and "La Corriveau" were published in the literary magazine Les Soirées canadiennes in 1862 and later reworked as

\footnotetext{
38 "Wicked creature, with her eyeless skull. ... [a] skeleton" (39, translated by Charles G.D. Roberts).

${ }^{39}$ This geographical area was designated as the Province of Québec under the Royal Proclamation of 1763. It was subsequently called the Province of Lower Canada between the Constitutional Act of 1791 and the union of Upper and Lower Canada in 1841. Following the union, the geographical area was renamed the Province of Canada until 1867.
} 
chapters three and four of Les anciens Canadiens, published the following year.

Lacourcière affirms that de Gaspé "aborde le sujet [de La Corriveau] à un triple point de vue qui correspond à trois niveaux différents de connaissance : celui de la documentation historique, de la survivance légendaire et enfin de la création romanesque" ("Le destin posthume" 72$).{ }^{40}$ In other words, de Gaspé constructed his version of La Corriveau by drawing on historical facts (courtesy of his long-time friend, librarian and archivist Georges-Barthélemi Faribault), elements of the folkloric tale that were passed down through oral tradition, and his own creative freedom. In Les anciens Canadiens, La Corriveau is depicted as a witch who attempts to trick a drunken man, François Dubé, into helping her cross the Saint Lawrence River to commune with her coven of witches and the Devil on the Île d'Orléans near Québec City.

A few months later, James MacPherson Le Moine's Maple Leaves: A Budget of Legendary, Historical, Critical and Sporting Intelligence (1863) was published, including a text entitled "Marie Josephte Corriveau, a Canadian Lafarge." More important than his iteration of the legend (in this version, Marie-Josephte attempts to kill Louis Dodier by slipping a noose on his neck during his sleep) is Le Moine's decision to frame $\mathrm{La}$ Corriveau as the Canadian version of the French woman Marie Lafarge. Lafarge was convicted for murdering her husband in 1840 by means of arsenic poisoning. While Le Moine does not claim Marie-Josephte Corriveau poisoned her husband, the parallel established between Lafarge and Corriveau was enough for Kirby to portray the latter as a poisoner in The Golden Dog (1877). Drawing on Les anciens Canadiens and Maple

\footnotetext{
${ }^{40}$ Tackles the subject [of La Corriveau] in a three-fold manner, corresponding to three different levels of interpretation: historical documentation, folklore, and literary creation.
} 
Leaves, Kirby was inspired to showcase La Corriveau as a poisoner and descendant of $\mathrm{La}$ Voisin, a French fortune-teller accused of being involved in witchcraft, alchemy, and poisons. ${ }^{41}$ Finally, Louis Fréchette's "La cage de la Corriveau" (1885), his most popular and extensive work on the subject, evokes de Gaspé's retelling of the legend and Le Moine's description of the cage. Although others have written on this folklore, the works of de Gaspé, Le Moine, Kirby, and Fréchette consolidated the literary gothic foundation of the Corriveau legend that would influence how future writers would understand and interpret her tale. ${ }^{42}$

Despite the fact that these nineteenth-century writers all adopt and adapt the same legend, the contexts behind their literary creations reveal differing goals in English- and French-Canadian writing traditions - goals that reflect the fractured sociopolitical landscape of the post-Conquest period. Indeed, after the Conquest of 1760, FrenchCanadian identity was constantly changing with respect to this group's fluctuating relationship with the English population and the continuous changes being made to the way they lived. From 1760 to 1862 (the latter being the date of publication of de Gaspé's nouvelles featuring La Corriveau), the geographical area of New France underwent several political, cultural, and social changes, many of which directly affected and created issues for members of the middle and upper classes. The emergence of print culture and its dissemination of public opinion on current events, as well as the later debates surrounding the division of power in Lower Canada's House of Assembly,

\footnotetext{
${ }^{41}$ Like Marie-Josephte Corriveau who became known simply as "La Corriveau," the historical character Catherine Monvoisin (also spelled Montvoisin) came to be known as "La Voisin."

${ }^{4}$ One example is Édouard Huot, whose article on La Corriveau entitled "Causerie" appeared in L'Opinion publique on March 21, 1872 (Ferland and Corriveau 188).
} 
contributed to the progressive transformation of French-Canadian consciousness and identity. Before 1760, Canadien referred to "des Français devenus Canadiens et dont le rapport à la France est progressivement modifié"; after the Conquest, however, this identity became closely related to "regret, nostalgie, sentiment d'abandon, oubli" (Lamonde 63) ${ }^{43}$ Tensions between the Canadiens and the British Crown would further complicate this French-Canadian identity as the latter was drawn into the struggles of the middle class during the period 1815-1834 (Lamonde 117). Many French Canadians began to see themselves as British subjects after being abandoned by France and seeing the benefits of replacing an absolute monarchy with a constitutional monarchy that allowed them to demand the rights and liberties of the British (Lamonde 115). Through the Québec Act of 1774, they gained the right to practice Roman Catholicism freely. French civil law and the seigneurial system were also restored; later, with the Constitutional Act of 1791, French Canadians obtained a house of assembly to which they quickly became acclimatized (Lamonde 64). Another major factor influencing the French Canadians' self-perception as British subjects was of course the French Revolution that began in 1789 , an event that eradicated any lingering attachment or sentiments of loyalty the inhabitants may have still had toward France (G. W. Brown 166). Notwithstanding these alignments with Britain, the British plans to unite Upper and Lower Canada to change the demographics of the French-Canadian majority in Lower Canada, as well as the British government's constant refusal to grant an elected legislative council, shaped French-Canadian self-perceptions again at the beginning of

\footnotetext{
43 "French colonists who had become Canadiens and whose relationship with France was gradually changing ... regret, nostalgia, a feeling of abandonment, of being forgotten" (45, translated by Phyllis Aronoff and Howard Scott).
} 
the 1830 s as the American experience began to provide a more appealing political model than that of the British, especially since the United States had an elected senate (Lamonde 116). This new self-perception comprised the liberalism and responsible government French Canadians strived to obtain, and was expressed in the motto "nos institutions, notre langue, nos lois," a reminder that despite sociopolitical changes and negotiations with Britain, French Canadians were francophones and Catholics following the French legal system and abiding by the system of seigneurial land tenure (Lamonde 176-77). ${ }^{44}$ French-Canadian consciousness and identity were continuously evolving, but it was the publications of the Durham Report (1839) and François-Xavier Garneau's Histoire du Canada depuis sa découverte jusqu'à nos jours (1845-48, 1852), following the Rebellions of 1837 and 1838, that provoked a wave of literary nationalism between the late 1830s and the 1890s. As a result of his oft-cited quotation that French Canadians were a people with no literature and no history, Cabajsky argues, Durham exacerbated sentiments of an oppositional nationalism that would end any appeal the British constitution and liberties previously had in the eyes of French Canadians ("Eighteenth-" 248). Indeed, Garth Stevenson claims that "the more characteristic response to the Durham report was the emergence of a new type of nationalism which differed substantially from that of the Patriotes" (121). Prior to the Durham Report, patriot nationalism was not exclusive to French Canadians. In fact, it attracted many anglophone inhabitants and even drew on certain American ideologies (Stevenson 121). This type of nationalism supported the idea of a liberal, republican, and secular society (Monière 92).

\footnotetext{
44 "Our institutions, our language and our laws" (146-47, translated by Phyllis Aronoff and Howard Scott).
} 
It focused on both cultural issues_- "our institutions, our language and our laws" - and political issues related to the desire for a responsible government and resistance against union, which "signifiait dans les faits la prise de contrôle du pouvoir politique par les Canadiens et le renversement des effets de la "Conquête"” (Monière 92). ${ }^{45}$

In contrast, la survivance was a new form of nationalism (one that was more conservative in nature following the failure of the Rebellions of 1837-1838) that emerged after the publication of Lord Durham's report and was primarily adopted by French Canadians. This survivance, as Stevenson argues, "was in part a reaction against the Durham report, the union of the two Canadas, and the threat of assimilation that these things represented. However, it was also in part a product of larger trends in the western world" (121). It would set aside political aspirations in order to focus exclusively on cultural issues, particularly the preservation of French-Canadian institutions, language, laws, as well as religion, now that English Canadians formed the majority and that English was the only language of official documents as a result of the Act of Union 1840 (Stevenson 127). According to Denis Monière, “mise en situation minoritaire, dépossédée du contrôle des institutions politiques, subjugée [sic] par une élite rétrograde, la nation canadienne se définit maintenant par son appartenance linguistique pour se distinguer de l'autre en ajoutant le qualificatif de français à son identité originelle : les Canadiens sont devenus des Canadiens français" (97). ${ }^{46}$ While French-Canadian survivance does possess

\footnotetext{
${ }^{45}$ In practice, signified the takeover of political power by the Canadiens and the reversal of the effects of the 'Conquest.'

${ }^{46}$ Forced into a minority position, dispossessed of the control of political institutions, and subjugated by a retrograde elite, the Canadian nation was now being defined by its linguistic belonging, distinguishing itself from the other by adding the qualitative 'French' to its original identity: the Canadians became French Canadians.
} 
a political dimension, the emergence of a new political identity based on language and ethnic origin is cultural in nature.

As part of the nationalist response to the Durham Report, Garneau refuted Durham's assertions that the history of French Canada was nonexistent and wrote Histoire du Canada, “deploying Romantic nationalism to revise French-Canadians' selfunderstanding" (Cabajsky, "Eighteenth-" 249). For a decade, Garneau had the intention of writing a history of Canada; the Report simply fuelled the necessity of completing such a project in a timely manner. His four-volume history "described a long struggle to survive, against heavy odds, by a people whose shared language, laws, and customs made them a nation. It was thus an important milestone in the definition of la survivance as a collective project" (Stevenson 123-24). Garneau's work spurred a mass wave of FrenchCanadian literary production. Participating in these developments was a literary magazine founded in 1861 called Les Soirées canadiennes. The magazine sought to curate a "recueil de littérature nationale" and aimed for a "récuperation ethnographique" (Lemire, La vie littéraire 517) by calling upon readers to "vulgariser la connaissance de certains épisodes peu connus de l'histoire de notre pays" (Lemire, La vie littéraire 517; Cabajsky, "Eighteenth-" 249). ${ }^{47}$ Les Soirées canadiennes wished to create a national literature by recording French Canada's legends and events.

While what Monière calls la survivance was localized in Canada East, this nationalist movement reflected the broader trend of romantic nationalism, which "by the beginning of the nineteenth century ... had become a large-scale movement that had

\footnotetext{
${ }^{47}$ A collection of national literature ... an ethnographic recuperation. ... "to popularize little-known events in the history of our country" ("Eighteenth-" 249, translated by Andrea Cabajsky).
} 
deeply influenced ideas and ideals of individuality, creativity, and personal experience" (Harvilahti 737). The decades following the end of the Napoleonic Wars in 1815 witnessed national and colonial liberation movements in Europe, movements that consequently caused questions concerning national consciousness and identity to emerge. Lauri Harvilahti argues that "among a number of emerging nations arose a need for recreating or reconstructing indigenous mythical pasts, poetic landscapes, and golden ages, often for the purpose of supporting a case for nation-state status" (737). The nation-state was constructed, in other words, through a return to and examination of the past.

One way of re-examining the past is through a reappropriation of folklore. The collection of folklore - the lore of the people or the folk — had become "a means of defining national identity and laying the ground work for nation-states" (Haase 662). German philosopher Johann Gottfried Herder “elaborated ideas about folk culture that would ultimately serve the cause of nationalism and provide the early theoretical foundation for the study of folklore" (Haase 662). Like French-Canadian nationalists, Herder believed that "national language was extremely important because, according to [his] organic view of culture, only through it could one think naturally and respond to and express the national soul" (Wilson 116). The preservation and expression of this national language was best done through the storytelling of national, folkloric tales that captured the "national soul." In his analysis of Herder and folklore, William A. Wilson concludes with the affirmation that romantic nationalism is indeed a folkloric movement. He argues that romantic nationalists and folklorists alike "have studied folklore items as survivals from the past. But while the latter have been content merely to work out historical reconstructions based on these survivals, the former have attempted not only to 
reconstruct the past, but also to revive it - to make it the model for the development of their nations" (Wilson 123).

Wilson's observations echo the project of Les Soirées canadiennes, as the magazine and its contributors collected and preserved the events of French Canada in the hope of generating renewed pride in French-Canadian culture. Much like the interrelated folklorist and romantic nationalist movements occurring across the world in the latter half of the nineteenth century, in Canada East there was, "surtout après 1850, une littérature canadienne-française qui s'approprie le folklore et les traditions afin d'appuyer la survivance de la tradition française au Canada français et en Amérique du Nord” (Gauthier 42). ${ }^{48}$ One may call this interest in folklore antiquarian, that is to say, that this interest in folklore was fundamentally a fascination with, and study of, the past. De Gaspé's chapter excerpts published in Les Soirées canadiennes were certainly an antiquarian response to Les Soirées canadiennes' call to record the legends of French Canada in order to assert its literary history. Although de Gaspé incorporates the FrenchCanadian legend of La Corriveau into his nouvelles, imagining the tale of a witch who seeks the help of a drunken man to cross the Saint Lawrence to commune with her devilish peers at the Île d'Orléans, his writing has a Scottish sensibility to it. Lacourcière argues that de Gaspé drew heavily on Robert Burns’s “Tam O’Shanter” (1791), a Scottish poem about a drunken man who meets a gibbeted witch wanting to commune with her coven. ${ }^{49}$ As Lacourcière states, "il paraît assez évident, sur le plan littéraire, que de Gaspé

\footnotetext{
${ }^{48}$ Especially after 1850, a French-Canadian literature that appropriates folklore and traditions in order to support the survivance of the French tradition in French Canada and North America.

${ }^{49}$ See Lacourcière's "Le Destin posthume de la Corriveau" for a brief comparative analysis of Les anciens Canadiens and "Tam O'Shanter."
} 
est débiteur de Burns pour l'atmosphère générale et plusieurs traits de ce morceau. Mais il a si bien assimilé son modèle en transposant un conte en vers écossais dans la prose du pays que jusqu'ici l'on n'a jamais détecté ses emprunts" (“Le destin posthume" 79). ${ }^{50}$ Burns's biographer Thomas Crawford claims that "the gathering and publishing of Scottish songs was one of the most important branches of the antiquarian movement of the eighteenth century; and on this subject, so closely bound up with the contemporary national revival, Burns became the greatest expert of them all" (258). While scholars such as Murray Pittock and Alex Broadhead believe that Burns "had ambivalent feelings regarding antiquarianism" (Broadhead 256), I concur with Ranald MacInnes's assertion that despite his opinions on antiquarianism, Burns was nevertheless "a kind of antiquarian, a collector of the intangible folk culture of songs, stories and traditions" (MacInnes 5). When de Gaspé elaborated a French-Canadian version of "Tam O'Shanter" fifty years later, he reproduced the intricate relationship between antiquarianism and nationalism found in Burns's literature, although his collection of legends was, of course, supportive of French-Canadian nationalism.

Louis Fréchette similarly took part in "promoting a romanticized nationalistic mythology of the colonization of New France" (Poirier 191). His poetic works "recall foundational moments in French-Canadian history" (Cabajsky, "Eighteenth-” 251). For instance, his epic poem La légende d'un peuple (1887) recounts the historical narrative of French Canada, and thereby gives substance to legendary French-Canadian exploits and

\footnotetext{
${ }^{50}$ It seems quite evident from a literary perspective that de Gaspé is indebted to Burns, drawing on the general atmosphere and several other elements of the work ["Tam O'Shanter"]. He transposed a narrative in Scottish verse to the prose of his country so seamlessly that until now, traces [of the source text] were undetectable.
} 
heroes. Fernand Rinfret describes this work as "l'œuvre capitale de M. Fréchette et, peut être [sic], avec l'Histoire du Canada de Garneau, l'œuvre capitale de toute notre littérature" (51). ${ }^{51}$ In contrast, Fréchette's multiple texts on La Corriveau do not recall major events in French Canada's collective history—-such as the discovery of the New World, the British Conquest of 1760, and the Rebellions of 1837-1838, all narrated in La légende d'un peuple_-but draw on his knowledge about Marie-Josephte Corriveau and his memories of the cage's exhumation. Through these texts, Fréchette preserved FrenchCanadian folklore and allowed it to proliferate in the service of a French-Canadian romantic nationalist project. As such, the publication of the first francophone texts on the legend of La Corriveau coincided with, and worked in the service of, the rise of FrenchCanadian nationalism and the efflorescence of a literature that promoted FrenchCanadian legends and history.

The fact that the legend of La Corriveau is at once a French-Canadian folkloric tale and a gothic narrative made it particularly valuable in the context of promoting Canadian romantic nationalist projects. The gothic genre is inherently related to folklore and can consequently be mobilized for nationalist projects as well. Harris asserts that the gothic derives from folklore, and David Punter even "identifies folk ballads as ... the source of the supernatural machinery that highlights the Gothic genre" (Harris 20). In fact, gothic tales perform a very similar function to folklore. For French Canadians in particular, they were a form of cultural preservation. Margot Northey explains that "although the historical romances of both [English- and French-Canadian] cultures

\footnotetext{
${ }^{51}$ M. Fréchette's magnum opus and, perhaps, along with Garneau's Histoire $d u$ Canada, the magnum opus of our entire literature.
} 
moved into gothic realms," French Canadians "idealized the past and exploited it for didactic purposes. For French-Canadian novelists as well as historians, history has been and is looked upon 'as a tool for shaping the present,' and thus history has always played a very special role in their fiction" (Northey 14). As a form concerned with the past, gothic tales were thus at least potentially didactic tools that could contribute to the construction of an idealized French Canadian past since such narratives "emphasized historical details for their own sake" (Northey 14).

Yet, although French Canada strongly promoted folklore, gothic narratives were more controversial fare. In 1837, the first Québécois novels, Philippe Aubert de Gaspé fils's L'influence d'un livre and François-Réal Angers's Les révélations du crime : ou, Cambray et ses complices, were published, both of which, Michel Lord argues, make use of gothic elements. In France, Charles Nodier had made tremendous efforts to popularize the term "école frénétique," a term he coined in 1821 to designate those writers who “promène[nt] l'athéisme, la rage et le désespoir à travers des tombeaux; qui exhume[nt] les morts pour épouvanter les vivants, et qui tourmente[nt] l'imagination de scènes horribles, dont il faut demander le modèle aux rêves effrayants des malades" (Nodier qtd. in T. Hale 58, changes made by Hale). ${ }^{52}$ This term is sometimes used synonymously with "la littérature cadavérique," "la littérature enragée, paradoxale et lycanthropique," "la littérature succube" (T. Hale 59), "le roman noir" (T. Hale 61-62), and "le roman terrifiant" (Thério and Lord 65). Although neither l'école frénétique, le roman frénétique, nor the other terms ever became a popular means of describing the French-Canadian

\footnotetext{
52 "Flaunt their atheism, their fury and their despair across the grave, who exhume the dead in order to terrify the living, and who torment the imagination with scenes of horror the only model for which is to be found in the fearful dreams of the insane" (58, translated by Terry Hale).
} 
gothic genre, French-Canadian writers were undoubtedly exploiting gothic elements. It is with some sense of alarm that, in describing the nineteenth-century French-Canadian "roman d'aventures" (some of which are the same novels Lord categorizes as "romans gothiques"), Nathalie Ducharme attempts to account for the French-Canadian fascination with the gothic and the desire to create frightening narratives of crime and perversion: la mise en fiction de la violence est ainsi liée au rapport que les lecteurs entretiennent avec leurs peurs. Le roman procure un stimulus au plaisir par l'épouvante, un défoulement compensatoire au sentiment d'impuissance, un guide moral et un manuel de survie en milieu urbain. Les premières œuvres de la production québécoise dressent le portrait d'une société extrêmement violente et dégradée, en raison d'une montée fulgurante de la criminalité. $(154)^{53}$ In response to such depictions of a violent and degrading society, as well as graphic descriptions of murder, writer Patrice Lacombe and Québec's first Premier Pierre-JosephOlivier Chauveau publicized their stance on the gothic novel in 1846, claiming that they were 'contre 'le genre terrible' et s'accord[ai]ent pour dire qu'il faut laiss[er] aux vieux pays, que la civilisation a gâtés, leurs romans ensanglantés" (Lord, En quête du roman gothique 10). ${ }^{54}$ In their view, this tradition of gothic writing ought to be left to nations like France and Great Britain.

\footnotetext{
${ }^{53}$ The fictionalization of violence is therefore related to the relationship readers maintain with their own fears. The novel stimulates pleasure through terror, a release that compensates for feelings of powerlessness, a moral compass, and an instruction manual to surviving urban spaces. The first Québécois literary works portray an extremely violent and degraded society as a result of the skyrocketing levels of criminality.

${ }^{54}$ Against 'the terrible genre' and agree to say that it is necessary to leave to the old countries, which civilization has spoiled, their bloodied novels.
} 
The negative reaction to the emergence of the first French-Canadian literary works, primarily due to their gothic inflection, demonstrates some of the difficulties involved in developing a national literature, especially when the nation is at a young stage (Lord, En quête du roman gothique 134; Sugars, Canadian Gothic 3). Lamonde remarks that in French Canada, "l'attrait pour la littérature de fiction commen[ça] vers 1820 et pr[it] des formes plus concrètes après 1830 avec le romantisme" (172). ${ }^{55}$ While poetry was the preferred medium for conveying nationalist sentiments (Lamonde 175; Biron et al. 57), emerging and growing in strength after 1820 was an appeal to the romantic novel, which was “illustré par un attrait nouveau pour la nature, l'exotisme, le gothique, l'Indien"' (Lamonde 172), especially due to recently published works of that genre by American authors such as James Fenimore Cooper. ${ }^{56}$ This interest in romantic novels may relate to the fact that "features of folklore define Romanticism itself, [and] as G. Malcolm Laws, Jr. in The British Literary Ballad summarizes, 'many of those qualities by which we identify romantic literature (supernaturalism, emotionalism, emphasis on adventure, Gothicism, and so on) are perfectly embodied in certain of the most memorable folk ballads"” (Harris 20). In Les anciens Canadiens when José tells the story of his father and La Corriveau, part of his narrative takes the form of folk ballads as he sings about his father's terrifying adventure with the supernatural witch.

The presence of gothic elements in French-Canadian literary works can perhaps be considered an offshoot of romantic literature since gothicism was one of the

\footnotetext{
55 "The interest in fiction began around 1820 and solidified after 1830 with Romanticism" (143, translated by Phyllis Aronoff and Howard Scott).

56 "Marked by a new attraction to nature, exoticism, the gothic, and Indians" (143, translated by Phyllis Aronoff and Howard Scott).
} 
components of the latter. Lord asserts that between 1837 and 1860, there were only seven French-Canadian gothic works, including L'influence d'un livre and Les révélations $d u$ crime. However, more commonly, "la terreur ne passera désormais que par le conte folklorique et n'aura pour but que de 'récupérer nos vieilles légendes avant que le peuple ne les ait oubliées', selon la formule empruntée à Charles Nodier" (Lord, En quête du roman gothique 11). ${ }^{57}$ As such, gothic elements were central to some folkloric tales such as the legend of La Corriveau, and could be promoted to preserve French-Canadian culture. In other words, the gothic elements present in the legend only served to enrich it for the purpose of cultural archiving.

While anglophone scholars such as Gerry Turcotte, Sugars, Marlene Goldman, and Carole Gerson have examined the relationship between the gothic genre and settler colonialism in English-Canadian literature, little consideration has been given to this relationship in Québécois and French-Canadian contexts. French Canada is indeed premised on dispossession, but this issue has only been raised by a handful of francophone scholars including Bruno Cornellier, Isabelle St-Amand, and Élise CoutureGrondin. They argue that there is a long history of French Canadians obscuring the fact that they were colonizers like the English, opting instead to focus on their role as the colonized in the French-English dynamics from the Conquest of 1760 onward (Cornellier

\footnotetext{
${ }^{57}$ Henceforth, terror would only pass through the folkloric tale and would only have the objective of 'recuperating our old legends,' to use Charles Nodier's words.
} 
49; St-Amand 205; Couture-Grondin 131). ${ }^{58}$ The attempts of Les Soirées canadiennes, Garneau, and de Gaspé, among many others, to preserve French-Canadian culture through writings on legends and histories reveal a desire to create self-indigenizing narratives that legitimize French Canadians' longstanding presence on the land. Such narratives are premised on the dispossession of Indigenous peoples and lands, and the erasure of any sign of French-Canadian colonial violence. As we will see in the following section, English-Canadian romantic nationalism and English-Canadian gothic perform similar acts of self-indigenization, but at the expense of both Indigenous peoples and French Canadians.

\subsection{La Corriveau in the Service of English-Canadian Romantic Nationalism}

While French-Canadian identity and nationalism were rapidly evolving over the decades, English-Canadian nationalism was slow-building. In the nineteenth century, English-Canadian identity was "marked by crisis and ambivalence" since settlers "identified both as British imperialists and as Canadian colonials, but the more they felt themselves to be members of an emerging and increasingly long-standing New World Society, the more distanced they felt from their European roots" (Moss and Sugars,

${ }^{58}$ In 2019, Zishad Lak and Pierre-Luc Landry organized a panel entitled "Le colonialisme de peuplement et la critique littéraire québécoise et franco-canadienne" ["Settler Colonialism and Quebec and Franco-Canadian Literary Criticism"] as part of the Association des littératures canadienne et québécoise's annual conference. Lak and Landry foregrounded their call for papers by claiming that "indeed, settlement colonization, in the Quebec and [French] Canadian context, is very rarely mentioned in French Humanities and Social Sciences Studies; we find only a few occurrences of the term in historiography and in scholarly literature. In literary studies, the term is still very uncommon, used only by a few researchers like Isabelle St-Amand (2015), Élise Couture-Grondin (2016) and Bruno Cornellier (2015)" (Landry and Lak, English translation provided on the ALCQ-ACQL website). This organized panel generated more scholarship on the topic as it attracted papers from scholars including Joëlle Papillon, Pierre-Luc Landry, Marie-Hélène Constant, Sandra Hobbs, and Zishad Lak, but settler colonialism in the Québécois and French-Canadian contexts remains an understudied field. 
"Canada as Home" 131). Laura Hastings similarly notes that toward the end of the century, English Canadians "continuously negotiated their position within the British Empire" (92), and that their identity was assuredly bound to British identity, at least to a certain extent. However, her argument differs from that of Moss and Sugars in that she claims English-Canadian identity was just as much bound to the antithesis of FrenchCanadian identity, and that English-Canadian nationalism emerged in part as a reactionary movement to French-Canadian nationalism. She observes that in a monthly periodical called The Anglo-Saxon published in Ottawa between 1887 and 1900, “constructions of [English Canadians'] British identity were inextricably connected to the reaction against French Canadian culture, especially Roman Catholicism and the French language" (Hastings 92). The periodical reflected the view of "many Protestant Canadians of British descent [who] firmly believed that the survival of Canada would require a singularity of race, religion, and language among its peoples" (Hastings 92). This romantic nationalist project evidently promoted the survival of an English-Canadian nation to the detriment of French-Canadian culture.

This culturally purist version of English-Canadian identity began to transform after the British North America Act and the "birth" of the Dominion of Canada in 1867. English-Canadian settlers continued to embrace their ties to Britain, but also wished to develop "a unique North American identity that distinguished [them] from the British as well as from the Americans" (Moss and Sugars, "A New Nationality" 263). Henceforth, the abstract image of Canada as a unified and distinct nation started to take form, especially with John A. MacDonald's national dream of a Canadian Pacific Railway that would connect the nation from sea to sea (R. Brown 16). However, something else was 
necessary: "more than a political document [or a railway], the creation of Canada required a body of people who contributed to the consolidation of that abstraction in the minds of citizenry" (Moss and Sugars, "Canada as Home" 263). It would require writers who would imagine, illustrate, and thereby create this sought-after image of the Canadian nation.

Part of the nation-building process, Kertzer argues, involves having nationalism mask novelty as antiquity (64). There seemed to be a lot of novelty during the period of Confederation: the "creation" of Canada, and more importantly, the creation of a Canadian literature that would validate and consolidate Canadian identity (Bentley 16; Gerson, A Purer Taste xiii). Rather than writing for a British audience, Canadian writers began to write for Canadians, exploring the Canadian landscape and questions of Canadian identity in their works. In "creating" a new national literature, EnglishCanadian writers "looked for elements that appeared 'indigenous' to the Canadian locale: nature, history, Native peoples, and French-Canadian habitants, among others" (Moss and Sugars, "A New Nationality" 269-70, italics in original). In other words, this novel writing was inherently based on images of local antiquity; English-Canadian writers appropriated the Canadian landscape, which was populated by Indigenous peoples and French Canadians who inhabited the land long before English settlers, in order to bolster English-Canadian cultural antiquity and thus extend their historical claim to continuous occupancy of the land. The incorporation of Indigenous and French-Canadian peoples and cultures into English-Canadian literature can be seen as an enactment of "the integrating power of the nation, which forcefully unif[ies] aspects of society that previously had been either distinct or only loosely associated" (Kertzer 64). Thus, the 
integrating power of the English-Canadian nation and the success rate of the EnglishCanadian strand of romantic nationalism, much like its French-Canadian counterpart, was partly measured through literary production.

With respect to the legend of La Corriveau, despite de Gaspé's and Fréchette's efforts to promote "French-Canadian cultural traditions," the recorded legends and stories of French Canada would "be used to lend English Canada a measure of authenticity (comparable to the role Scottish antiquities [such as Burns's poetry] would play for Great Britain)" (Sugars, Canadian Gothic 78). The folkloric and gothic nature of the legend of La Corriveau makes the narrative an ideal instrument in the English-Canadian romantic nationalist endeavour. In contrast to the French-Canadian use of the gothic as a didactic tool, English Canadians perceived French-Canadian gothic material as a source of curiosity and excitement. With respect to English Canadians' use of the gothic, Northey writes, "English Canadians tended to use the past as a vivid backdrop for exciting adventure and to be interested in the details of early French Canada as fascinating, factual curios" (14). In other words, the use of the gothic among English Canadians showed their fascination for French Canada and provided them with a way of exploring their inhibitions while remaining culturally and spatially dissociated from such material. This dissociation from and othering of French Canada "renders it acceptable as a site of Gothic excess" and "assimilable for national self-constitution. This otherness enabled EnglishCanadian authors to revel in an ancient—and, in their view, Gothic_-history, which could be modified and incorporated for English-Canadian nation-defining purposes" (Sugars, Canadian Gothic 77). 
Gerson similarly asserts that "over the course of the nineteenth century, fascination with the otherness of French Canada muted into a sense of identification with Québécois and Acadian culture, folklore, and history which helped enrich English Canada's own relatively barren national image" (A Purer Taste 111). This fascination with French Canada was intertwined with a certain level of fabrication; English-Canadian writers would offer "a carefully constructed, indeed willed, French-Canadian Gothicism ... which was connected to a desired version of French Canada" (Sugars, Canadian Gothic 77). Through the gothic, a literary genre which has highly adaptable qualities (allowing it to transform into something new) and inherently deals with the return of the repressed (antiquity), it was possible to bring together the novelty and antiquity necessary to the English-Canadian romantic nationalist project. In fact, "many Canadian writers chose to adapt the Gothic to colonial cultural-historical circumstances expressly because the Gothic was tied to the very elements that settlement [English] Canada seemed to be lacking: cultural mythology and historical antiquity" (Sugars, Canadian Gothic 4). The gothic would "contribut[e] to an emergent national consciousness that was founded on a form of constitutive haunting" (Sugars, Canadian Gothic 4).

With this interest in the gothic, English Canada saw an efflorescence of gothic works in the nineteenth century. Turcotte and Sugars affirm that "settler locations would seem to invite gothic figuration, not only in terms of the monstrous or grotesque (as Margot Northey outlines in her study) but also in terms of subjective and national interiority and unsettlement" (viii). Recalling Kertzer's claim concerning the integrating power of the nation that forcefully unifies elements of a society that were loosely associated or distinct, the gothic genre therefore appears to draw out the tensions of 
Canada as a settler nation: the manifestation of unsettlement and the desire to settle that which is unsettled by unifying the aforementioned elements that are loosely associated or distinct within the nation. Sugars notes that "in many works, the process of assimilation into the larger Canadian national context is posited as a necessary 'civilizing' process that the French Gothic must undergo in order to become Canadian" (Canadian Gothic 77). Thus, the incorporation of French-Canadian folklore in nineteenth-century EnglishCanadian gothic fiction, while appearing as a budding fascination with French Canada, became in fact, a way of civilizing, managing, and manipulating public perceptions of the latter.

Le Moine's and Kirby's adaptations of the legend of La Corriveau, advertently or otherwise, served such a purpose as they supported the English-Canadian romantic nationalist project. Le Moine was born in an English and French household, and educated in both languages. He wrote in both languages, too, and was interested in the history of North America, especially Québec City and its surroundings (R. Le Moine). In line with this particular research interest, Le Moine's Maple Leaves "sought to preserve and commemorate the culture and folk history of Lower Canada" (Sugars, Canadian Gothic 76) by presenting "a portion of the historical, legendary and sporting intelligence ... scattered through many old books and memoirs, not of easy access to the generality of readers" (J. M. Le Moine v-vi)—or, one might argue, to anglophone readers who could not read those French books and memoirs. While Le Moine saw his endeavour as a demonstration of his will to share French-Canadian culture and "the love of [his] country" (vi), English Canadians reading his work around the time of the Canadian 
Confederation "began to see in French Canada a source of resonant cultural material" (Sugars, Canadian Gothic 76-77).

Kirby was one such English-Canadian author. Kirby read Maple Leaves during a trip to Québec City and, as he told Le Moine, it "had started him on the trail of the golden dog and given him the idea of composing a novel on the subject" that culminated in the publication of The Golden Dog in 1877 (Hayne 50). Cabajsky considers Kirby's work to be "one of only two English-Canadian novels in the nineteenth century to have been accepted into the canon of Québec literature" ("Introduction" 18). Unlike the FrenchCanadian folklorists who preceded him, Kirby used gothic elements such as La Corriveau and the Chateau of Beaumanoir, not to recover and promote French-Canadian culture and history - a culture and history that were not his own — but rather to justify the political ascendancy of English Canada. ${ }^{59}$ Setting his narrative around the time of the British Conquest, he embedded a "loyalist confidence in Canada's ties to Britain as a guarantee of social stability, [and] as an unquestionable source of moral and cultural authority" (Dyer 581) into his retelling of major events in French Canada.

French and English Canadians used representations of the past to different ends. Whereas French-Canadian nationalists used historical figures to substantiate the longevity of the "'national' struggle," English Canadians used the same figures to "[represent] an attempt to appropriate the past of French Canada in order to provide a longer genealogy to the Canadian nation and to imply a continuous record of progress that linked French and English Canadians" (Coates and Morgan 44). As I noted in the

\footnotetext{
${ }^{59}$ One of the settings of Kirby's The Golden Dog, the Chateau of Beaumanoir is "the abode of the Royal Intendant of New France" (Kirby 57) and "the scene of the gorgeous feasts of the Intendant" (62).
} 
introduction, Le Moine's repurposing of La Corriveau, and even more so Kirby's, are salient examples of Coates and Morgan's argument concerning the use of historical figures in support of French-Canadian or pan-Canadian nationalist projects. Coates and Morgan make arguments similar to those of Kertzer, Sugars, and Moss: English Canadians made use of French-Canadian culture to elongate and substantiate their own antiquity. Through its multiple literary iterations, the figure of La Corriveau came to embody for French-Canadian writers the longevity of the national struggle. She was not only a French-Canadian historical figure caught in an unjust trial and an incomprehensible English courtroom, but also a folkloric figure belonging to the cultural legends of French Canada. Conversely, Kirby’s Anglo interpretation of La Corriveau situates the figure alongside the corrupted Intendant François Bigot, as well as alongside the immorality and incompetence of France and its Ancien Régime. Consequently, New France is portrayed as desperately needing Britain to free it of such corruption.

La Corriveau has thus proven to be a figure of considerable ideological plasticity in the history of French- and English-Canadian literary cultures, and in the burgeoning of their respective national consciousnesses. Folkloric and gothic materials were being mobilized to help French and English Canada's respective romantic nationalist projects. They were used either to unite or divide cultural distinctions in Canada. In making use of the same folkloric and gothic traditions in an attempt to achieve a romantic nationalist project, French and English Canadians thus underscored different aspects of the legend of La Corriveau: French Canadians focused on the antiquarian nature of the folklore, preserving and studying the stories of their past, to divide and distinguish its people from English Canadians, whereas the latter drew on French-Canadian folklore to demonstrate 
cultural uniqueness in relation to Great Britain and the United States (Gerson, A Purer

Taste 111) and simultaneously construct a homogeneous, pan-Canadian national identity.

\subsection{The French-Canadian Aristocracy and British Political Ascendency in Les anciens Canadiens}

Scholars studying de Gaspé's Les anciens Canadiens (1863) are still hesitant about the novel's political leanings. Cabajsky argues that "Les Anciens Canadiens deploys folklore, descriptions of cultural customs, and the author's personal memories of life under the French regime to defend the particularity of French-Canadian national character while ultimately advocating intercultural rapprochement between French and English Canadians" (“Eighteenth-” 249). Conversely, Jacques Castonguay asks, doit-on y voir un signe de la difficile cohabitation des anglophones et des francophones au pays? ... [En même temps,] l'auteur des Anciens Canadiens ne fait-il pas dire à Blanche d'Haberville qu'il est naturel et souhaitable "que les races française et anglo-saxone [sic], ayant maintenant une même patrie, vivant sous les mêmes lois, après des haines, après des luttes séculaires, se rapprochent par des alliances intimes?" (Philippe Aubert de Gaspé 138-39) ${ }^{60}$

These questions arise from the varying relationships de Gaspé had with the English population. His father, Pierre-Ignace, was born at the end of the French regime (August 14, 1758) and fought against the Americans during the American Revolutionary War as

\footnotetext{
${ }^{60}$ Should one see in the novel a sign of strenuous cohabitation between the anglophones and francophones of the country? ... [Concomitantly,] does the author of Les anciens Canadiens not make Blanche d'Haberville say that it is natural and desirable "that the French and Anglo-Saxon races, now sharing one same country, living under the same laws, after the hostilities, after the secular battles, become closer through intimate alliances?"
} 
an “'haut torie' et ... 'royaliste' qui préférait George III à Napoléon I ${ }^{\text {er }}$... [et qui] servit aussi la couronne britannique en qualité de milicien” (Castonguay, “Aubert de Gaspé, Pierre-Ignace"). ${ }^{61}$ During his childhood, Philippe went to a co-ed, bilingual academy and boarding school for three years (1795-1798) before his father moved him to an AngloProtestant school (1798-1806). Castonguay explains that "bien qu'il [Pierre-Ignace] était très attaché à la langue française qu'il se faisait un devoir de défendre, même publiquement, il n'était pas moins convaincu de l'importance de maîtriser l'anglais" (Philippe Aubert de Gaspé 57) ${ }^{62}$ Afterward, Philippe decided to pursue law school and, following his father's recommendation, went to study under the tutelage of Jonathan Sewell, the attorney-general and advocate-general of Lower Canada. Sewell was "bien perçu par les anglophones de Québec qui appréciaient sa grande compétence en matière de droit et voyaient en lui un ardent défenseur des droits de la couronne" (Castonguay, Philippe Aubert de Gaspé 60). ${ }^{63}$ However, francophones "voyaient surtout en lui un adversaire prônant l'anglisation [sic] de leurs enfants et l'affaiblissement de leur église. Ils lui faisaient en particulier grief d'être à l'origine de projets de loi injustes et d'être responsable d'arrestations et de condamnations arbitraires" (Castonguay, Philippe Aubert de Gaspé 60-61). ${ }^{64}$ Nevertheless, he was a prestigious figure under whom Philippe was simultaneously able to study law and perfect his English, reading and translating writers

\footnotetext{
${ }^{61}$ Far-right Tory and ... royalist who preferred George III over Napoleon I ... [and who] also served the British crown as a militiaman.

${ }^{62}$ While he [Pierre-Ignace] was so attached to the French language that he made it his mission to defend it, even publicly, he was not less convinced about the importance of mastering English.

${ }^{63}$ Well perceived by the anglophones of Québec, who appreciated his high level of competence in the matter of law and saw in him a fervent defender of the rights of the Crown.

${ }^{64}$ Mostly saw in him an adversary advocating for the anglicization of their children and the weakening of their church. They particularly criticized him for being at the origin of projects concerning unjust laws and for being responsible for arbitrary arrests and condemnations.
} 
such as Walter Scott (Castonguay, Philippe Aubert de Gaspé 61-62). Subsequently, Philippe was able to climb the ranks in politics, partially due to Sewell's power and influence, and "les bonnes relations qu'entretenait Philippe avec les anglophones et les officiers britanniques de la garnison de Québec eurent à cette époque une certaine incidence sur sa vie publique et privée" (Castonguay, Philippe Aubert de Gaspé 65) ${ }^{65}$

Many years after his incarceration due to the debt he owed to the Crown (he was incarcerated from 1838 to 1841), Philippe regained “contact avec les Québécois de langue française qu'il avait forcément négligés depuis nombre d'années, [et] il s'éloignait du même coup de la communauté anglophone avec laquelle il avait beaucoup frayé et travaillé du vivant de son père ... il ignorera la milice qui l'avait rayé de ses rangs lorsque ses difficultés financières furent connues" (Castonguay, Philippe Aubert de Gaspé 126) ${ }^{66}$ Despite his long-term amicable relations with British officers, he was never cast out by the francophone community. He had taken "plus d'une fois la défense de ses compatriotes d'origine française" when members of the newspaper Le Canadien were accused of treason and consequently incarcerated in 1810 (Castonguay, Philippe Aubert de Gaspé 67). ${ }^{67} \mathrm{He}$ was also one of the founders of the Club des anciens, a group for “ces férus d'histoire [qui] en vinrent à se réunir tous les jours durant les mois d'hiver, entre 1850 et 1860" (Castonguay, Philippe Aubert de Gaspé 129) ${ }^{68}$ In those years, he

\footnotetext{
${ }^{65}$ The good relations Philippe maintained with anglophones and British officers of the Québec garrison had at the time a certain impact on his public and private life.

${ }^{66}$ Contact with the Québécois of French language who he necessarily neglected for a number of years, [and] at the same time, he distanced himself from the anglophone community with whom he was associated and with whom he worked when his father was alive ... he ignored the militia that had dismissed him when his financial difficulties became known.

${ }^{67}$ More than once to the defense of his compatriots of French origin.

${ }^{68}$ Those passionate about history [who] reunited every day during the winter months, between 1850 and 1860.
} 
began writing fragments of Les anciens Canadiens and would read them to his peers, namely l'Abbé Henri-Raymond Casgrain and the members of the newspaper called the Foyer canadien. According to Casgrain, Philippe was inspired to write his novel as a response to Charles Nodier's assertion, "hâtons-nous de raconter les délicieuses histoires du peuple avant qu'il les ait oubliées" (C. Roy 85), which became the motto of Les Soirées canadiennes in $1861 .{ }^{69}$ Although he reconnected with the francophone community, he remained close to the anglophone community throughout this period since his wife was the daughter of a British officer, three of his children married anglophones of Scottish descent, and two others married anglophones of Irish descent (Castonguay, Philippe Aubert de Gaspé 138).

While Castonguay hesitates to position de Gaspé's novel within a strictly Frenchor English-Canadian romantic nationalist project, critics such as Enn Raudsepp argue that de Gaspé's political leanings tilt decisively toward the British officers:

clearly, it is the defence of aristocratic privilege that takes precedence over nationalism in Aubert de Gaspé's mind. As a French gentleman, he is closer in spirit to the aristocratic English officers of the occupation than to the Quebec peasants, for ... he shares with them a common cultural tradition which transcends nationality. British rule, far from being a disaster, is actually a blessing in disguise. (Raudsepp 109)

Unlike Castonguay, Raudsepp does not believe the debate concerns de Gaspé's role in French or English nationalism. Rather, he suggests that de Gaspé's desire to maintain aristocratic privilege supersedes his nationalist interests, a claim that, in concert with that

\footnotetext{
${ }^{69}$ Let us hurry to recount the delectable stories of the people before they forget them.
} 
of Castonguay, raises questions concerning the roles of French- and English-Canadian nationalisms, as well as aristocratic privilege, in de Gaspé's novel.

And yet, it ought to be clear that in drawing on the history between Scotland and England in Les anciens Canadiens, specifically Scotland's recent allegiance to the English Crown, de Gaspé anticipates and advocates for New France’s allegiance to Britain following the Conquest of 1760 . In so doing, while the novel participates in a French-Canadian romantic nationalist project by preserving cultural stories such as the legend of La Corriveau and having them symbolize resistance to metanarratives concerning the peaceful and homogeneous creation of the Canadian nation-state, it does not contradict the romantic nationalist project of English Canada. Due to his participation in both francophone and anglophone communities and his desire to preserve his aristocratic position, de Gaspé establishes La Corriveau as a figure of otherness that proves congenial to both French- and English-Canadian romantic nationalist functions. Indeed, during de Gaspé's time, there were sociopolitical tensions other than those dividing anglophones and francophones. Jean-Herman Guay explains that "the EnglishFrench divide was only one factor during this period [after the Rebellions of 1837-1838], which was defined primarily by the conflict between aristocracy and the bourgeoisie, between tradition and modernity" (6). De Gaspé's exploration of these various interrelated and complex factors consequently presents some ambivalent passages. Due to La Corriveau's plasticity in Les anciens Canadiens, she becomes a multilayered symbol that signifies a wide range of cultural, political, and class identities pertaining to French, British, Scots, and Indigenous peoples in the first francophone work depicting her legend. My analysis looks at how de Gaspé's work paradoxically supports both French- and 
English-Canadian romantic nationalist projects. The figure of La Corriveau symbolizes French Canadians and acts as a haunting symbol of the past that sheds light on the violent creation of the Canadian nation state at the moment of the British Conquest. However, French- and English-Canadian cultures are not definitely distinct and the novel shows how this binary becomes undone in cultural practice. Indeed, La Corriveau is also associated with British officers, embodied in the sorcerers of the Île d'Orléans, as well as the Scottish and Indigenous characters of the novel. These associations thereby ultimately entrench Les anciens Canadiens in English-Canadian romantic nationalism.

Les anciens Canadiens is a novel about two childhood friends, the FrenchCanadian Jules d'Haberville and the Scottish orphan Archibald "Arché” Cameron of Locheill. ${ }^{70}$ It recounts their early years together at the Séminaire de Québec. Jules and Archibald befriend each other, and the latter is quickly considered an adopted son and brother to the d'Haberville family. Set during the time of the Conquest of 1760, both men go to war and find themselves on opposite sides, with Jules fighting for the French, and Archie having to fight for the English. The novel participates in the French-Canadian romantic nationalist project as it successfully captures the legends and history that the literary magazine Les Soirées canadiennes sought to promote and publish. It is a work that thoroughly embodies the "simple tableau édifiant de la vie d'autrefois" (Cardinal 13). ${ }^{71}$ In his monograph-length study of the work, Cardinal divides the novel into two sections: the first relates "surtout [à] des légendes et [à] de jolis tableaux de mœurs de la vie canadienne d'autrefois," whereas the second, "en relatant la Conquête militaire de la

\footnotetext{
${ }^{70}$ In de Gaspé's original francophone text, Archibald's nickname is Arché. In English, the character's nickname is Archie.

${ }^{71}$ Simple tableau edifying life in the old days.
} 
Nouvelle-France par les Anglais, s'inscrirait plus directement dans le cadre de son intrigue romanesque (bien que cette partie compte aussi son lot de légendes, de chansons et de scènes pittoresques)" (12-13). ${ }^{72}$ However, as Cardinal points out, this division is not always clear cut, as the historical backdrop is infused with legends and songs, and vice versa. The legend of La Corriveau, introduced in Chapters 3 and 4, is one of the most striking instances of this combination of French-Canadian history and cultural legends. The legend's presence in the novel is a form of cultural preservation since it records a fragment of French-Canadian culture. However, the figure of La Corriveau plays a more complex role as it brings together the notions of remembering, haunting, and nation.

De Gaspé portrays the figure of La Corriveau as a revenant who harasses José's father, François Dubé, and thereby establishes the legend as a haunting symbol of the past that memorializes a violent moment in the creation of the Canadian nation-state. Renan argues that "l'unité se fait toujours brutalement" (8). ${ }^{73}$ More importantly, this brutally achieved unity is intertwined with the notion of forgetting, "un facteur essential de la formation d'une nation" (Renan 8) ${ }^{74}$ Goldman similarly asserts that "amnesia and repression typically obscure the often violent creation of nation-states" (DisPossession 46). In other words, forgetting the violence inherent to the nation-building process is a necessary step toward accepting the unity of a nation. The figure of La Corriveau's presence as a revenant in de Gaspé's novel acts as a counternarrative to amnesia and repression, but only for some - namely, the French Canadians. Even as it serves as a

\footnotetext{
${ }^{72}$ Mostly to legends and beautiful tableaux of the mores of old-fashioned Canadian life ... by chronicling the military Conquest of New France by the British, is inscribed more directly within the novel's storyline (although this section also includes its share of legends, songs, and picturesque scenes).

73 "Unity is always effected by means of brutality" (11, translated by Martin Thom).

74 "A crucial factor in the creation of a nation" (11, translated by Martin Thom).
} 
symbol of French Canadians' refusal to be colonized by British officers, La Corriveau's haunting presence can also be read as erasing French Canada's colonial history. In other words, La Corriveau's ghostly and perduring presence claims French Canadians' longstanding existence on the land in a way that encourages a type of amnesia that obscures their own role in colonization. La Corriveau is thus a supernatural manifestation that strategically exposes a specific moment in the violent creation of nation-states and the brutality inherent to national unity, while simultaneously forgetting a prior (and ongoing) moment of national brutality in which French Canada also participates. In any case, as previously mentioned, the legend is intrinsically tied to its inception around the time of the British Conquest of 1760. For the French Canadians of de Gaspé's novel, therefore, the figure of La Corriveau is correspondingly "un fantôme qui ... évoque la défaite des plaines d'Abraham, dans la mesure où cette défaite, marquant l'avènement de la sujétion politique, ne cesse par la suite de hanter les survivants puis les héritiers" (Cardinal 28). ${ }^{75}$

By setting his narrative in 1757 and introducing the figure of La Corriveau as a presence that has long been haunting inhabitants, de Gaspé closely intertwines the political backdrop of the British Conquest of 1760 with the materialization of a haunting past representing unresolved issues of colonialism by creating "un monde peuplé de fantômes ou de créatures infernales" (Cardinal 25). ${ }^{76}$ Indeed, New France offers a space wherein 'l'histoire politique n'est pas sans fantômes ni revenants dès lors que les

\footnotetext{
${ }^{75}$ A phantom that ... evokes the defeat at the Plains of Abraham, insofar as this defeat, which marks the advent of political subjection, does not cease to haunt the survivors and the inheritors afterward.

${ }^{76}$ A world populated by ghosts or infernal creatures. As a sidenote, de Gaspé acknowledges the anachronism of setting La Corriveau as a revenant figure before the Conquest in his endnotes and details the legend of La Corriveau on pp. 294-299.
} 
communautés conquises ou dominées ont bien souvent des morts (des héros) ... autant de morts qui, par conséquent, ne cessent de hanter cet espace, de faire retour pour être pleinement reconnus" (Cardinal 27). ${ }^{77}$ The phenomenon Cardinal observes relates to the "return of the repressed." These ghosts and revenants represent the memories upon which “une communauté politique prend forme, ou conscience d'elle-même" (Cardinal 27). ${ }^{78}$

As Turcotte and Sugars assert, this type of haunting is typical in settler-colonial nations such as Canada. They explain that "gothic revenants are often used to figure the culpable history of the Canadian nation-state ... The construction of the Canadian nation as a homogeneous and civil society ... is belied by those people and cultures whose suppression made national consolidation possible and yet who remain as 'haunting' presences that challenge the national imaginary" (xiii-xiv). The figure of La Corriveau as a gothic revenant acts as a haunting presence that challenges the assimilation of French Canadians into the construction of a "homogeneous and civil" Canadian nation.

Louis Lasnier argues that the way the witch mounts onto François’s back, “l'écrasant, voulant rejoindre le sabbat des sorciers sur l'île, décrits comme des soldats anglais dans leur uniforme particulier, préfigure la lutte militaire entre Jules et Arché” (88). ${ }^{79}$ The symbolism of the British soldiers as fiends is particularly significant when taking into account the description of Montgomery, the leader of the British soldiers, who is “décrit comme un être vil, perfide et démoniaque, puisqu'il a commandé cette 'œuvre

\footnotetext{
${ }^{77}$ Political history is not without ghosts or revenants since conquered or dominated communities often have casualties (heroes) ... many casualties that, consequently, never cease to haunt the space, coming back to be fully recognized.

${ }^{78}$ A political community takes shape, or becomes aware of itself.

${ }^{79}$ Squashing him, wanting to rejoin the sabbath of the sorcerers on the island, described as English soldiers in their peculiar uniform, anticipates the military battle between Jules and Arché. In analyzing this passage, Lasnier erroneously describes the encounter with La Corriveau as happening to José, when in fact, it happened to his father, François.
} 
diabolique de dévastation' ([de Gaspé] p.222) et qu'il poursuit Arché d'une 'haine satanique' (p.224)" (Cardinal 56). ${ }^{80}$ Lasnier accordingly interprets the figure of La Corriveau as more than a mere evocation of the defeat at the Plains of Abraham, affirming that "l'agressivité de la Corriveau correspond à la frustration subie par les Canadiens pendant l'occupation militaire britannique (1760-1763). ... Avec sa légende [de la Corriveau], la peur sous-tendant l'agressivité s'empare de la population" $(87-88) .{ }^{81}$ The witch's weight on the man's back therefore represents the forthcoming metaphoric weight of defeat on the French-Canadian population.

Indeed, the descriptions surrounding the exchange between La Corriveau and François microcosmically evoke the imminent battle between the French Canadians and the English. François tells La Corriveau that her dragging cage "aura déraciné toutes les pierres et tous les cailloux du chemin du roi" (de Gaspé 44$).{ }^{82}$ The uprooting of the Chemin du roi, the first vehicle-suited road connecting one end of New France to the other, symbolizes the destruction of the colony's unity and the déracinement of FrenchCanadian identity. As soon as François utters these words, the drumming ceases and “tous les sorciers s'arrêtent et poussent trois cris, trois hurlements, comme font les sauvages quand ils ont chanté et dansé 'la guerre', cette danse et cette chanson par lesquelles ils préludent toujours à une expédition guerrière. L'île est ébranlée jusque dans

\footnotetext{
${ }^{80}$ Described as a vile, perfidious, and demonic being, since he commanded this 'diabolical work of devastation' and pursues Arché with satanic hate.

${ }^{81}$ The aggression of La Corriveau corresponds to the frustration suffered by the Canadiens during the British military occupation (1760-1763).... With her legend [that of la Corriveau], the fear underlying the aggression seizes the population.

82 "Must have torn up all the stones on the king's highway!" (52, translated by Charles G.D. Roberts).
} 
ses fondements" (de Gaspé 44). ${ }^{83}$ Likened to Indigenous warriors (an imperative point that I will return to later), the sorcerers appear ready to begin a war that will spread from the Île d'Orléans to New France as a whole. The witch weighs down on François like a burden while also being burdened by a heavy weight herself: "la cage était pesante, et, à chaque élan qu'elle prenait, elle retombait à terre avec un bruit rauque, sans lâcher pourtant les épaules de mon pauvre défunt père, qui pliait sous le fardeau" (de Gaspé 43). ${ }^{84}$ As such, La Corriveau and François are mirror images of each other, both having experienced loss at the hands of British officers; La Corriveau loses her trial and is consequently executed, whereas François symbolizes the French-Canadian habitant who will be destitute after the military battle of 1759 .

However, if the sorcerers are, as Lasnier implies, meant to symbolize British soldiers, then La Corriveau's desire to convene with the coven of sorcerers can be read as a desire for an alliance between French Canadians and British soldiers. When the witch sees François, she cries out, "mon cher François ... fais-moi le plaisir de me mener danser avec mes amis de l'île d'Orléans" (de Gaspé 43) and again, "mène-moi danser avec mes bons amis" (44). ${ }^{85}$ The witch's desire to unite with her fellow sorcerers is reciprocal; one of the sorcerers shouts at François “d'une voix de tonnerre : veux-tu bien te dépêcher, chien de paresseux, veux-tu bien te dépêcher, chien de chrétien, de traverser

\footnotetext{
83 "All the goblins halted and gave three yells, three frightful whoops, like the Indians give when they have danced that war-dance with which they always begin their bloody expeditions. The island was shaken to its foundation" (52, translated by Charles G.D. Roberts). While Roberts translates "sorciers" as "goblins," I will refer to these creatures as sorcerers.

84 "The cage was heavy, and at every leap she fell back again to the ground with a hoarse cry, without losing her hold, however, on the shoulders of my late father, who bent under the burden" (50, translated by Charles G.D. Roberts).

85 "My dear Francis ... do me the pleasure of taking me to dance with my friends of Isle d'Orléan? [sic] ... take me over to dance with my dear friends" (51-52, translated by Charles G.D. Roberts).
} 
notre amie?" (de Gaspé 45) ${ }^{86}$ Any potential union is halted by François, who refuses to help La Corriveau cross the Saint Lawrence and is consequently strangled to the point of unconsciousness. La Corriveau and François therefore anticipate two different outcomes for the defeat at the Plains of Abraham: La Corriveau represents the assimilation of French Canadians into a British hegemonic state of power, whereas François represents the refusal to facilitate or participate in such assimilation. Indeed, the little bird who asks François "qué-tu" when he gains consciousness, to which he replies "il m'est malaisé de répondre à ta question, car je ne sais trop qui je suis ce matin" (de Gaspé 46), suggests that regardless of the outcome, the nature of French-Canadian identity will inevitably change after the Conquest. ${ }^{87}$

La Corriveau's and François's reactions to the fiendish British officers represent two mainstream and diametrically opposed responses to the British Conquest, responses that are informed by issues of class. Michel Brunet asserts that "les dirigeants et les porteparole officiels d'une collectivité constituent toujours une minorité. Celle-ci encadre et guide toute la population" (170). ${ }^{88}$ In New France, prior to the Conquest of 1760, the colony's administrative minority consisted "d'administrateurs et de fonctionnaires, de chefs militaires, d'entrepreneurs capitalistes, de dirigeants ecclésiastiques et de grands propriétaires terriens" (Brunet 171) ${ }^{89}$ In a general sense, the French Canadians had “confiance envers leurs dirigeants" and "acceptaient leur autorité avec la conviction que

\footnotetext{
86 "With a voice of thunder: 'Will you make haste, you lazy dog? Will you make haste, you cur of a Christian, and ferry our friend across?"' (53, translated by Charles G.D. Roberts).

87 " Qué-tu (Who art thou) ... it is not very easy to answer your question, for I'm not very certain this morning just who I am" (54, translated by Charles G.D. Roberts).

${ }^{88}$ The leaders and official spokespeople of a collective always constitute a minority, which manages and guides the entire population.

${ }^{89}$ Of administrators and civil servants, military chiefs, capitalist entrepreneurs, ecclesiastic leaders, and large landowners.
} 
celle-ci était au service de la collectivité" (Brunet 173). ${ }^{90}$ The new tripartite dynamic between French Canadians, their leaders, and the British officers emerging after the Conquest obliterated this confidence. Brunet argues that "dès les premières années de la domination anglaise, un divorce inévitable se produit entre les Canadiens et ceux qui se disent leurs chefs de file. Aux yeux du peuple, les membres de la classe dirigeante de la colonie ne sont que les collaborateurs serviles des vainqueurs" (174). ${ }^{91}$

Indeed, the newfound "tense yet cordial" relationship between "the British colonial rulers and the traditional clerical and seigneurial leaders of French Canada" was necessary and benefitted these parties' mutual interests by "reinforc[ing] the existing colonial and social political structures" in place (Behiels). Governor Guy Carleton, who succeeded James Murray in 1766, wanted to incorporate "les familles nobles dans le nouvel ordre politique, afin qu'elles aident à la préservation de l'ordre social, ce qui était un objectif commun, et à la consolidation de la domination britannique" (Ruggiu 51). ${ }^{92}$ This relationship was particularly beneficial for seigneurs. Jacques Mathieu remarks that "whether they were of noble or common descent, the seigneurs were a privileged class" and that the seigneurial system "played a leading role in building and maintaining social relations in New France" (Mathieu). Allan Greer similarly argues that "the economic ascendancy of the 'aristocracy' was intimately bound up with its political ascendancy ...

\footnotetext{
${ }^{90}$ Confidence in their leaders ... accepted their authority with the conviction that they were at the service of the collective people.

${ }^{91}$ Since the first years of English domination, an inevitable divorce occurred between the Canadians and those who considered themselves their leaders. In the eyes of the people, the members of the colony's leading class were but subservient collaborators of the victors.

${ }^{92}$ Noble families into the new political order so that they could help with the preservation of the social order, which was a common objective, as well as with the consolidation of British domination.
} 
the power of superiors over inferiors had to be immediate, personal, and overt. There could be no admission that peasants, clerics, and seigneurs were equal" (89-90).

La Corriveau and François's encounter symbolizes the internal split in the FrenchCanadian population, one spurred by the upper classes' desire to associate themselves with the English officers. ${ }^{93}$ In light of these power structures, La Corriveau's haunting presence would not only evoke the defeat at the Plains of Abraham or the resentment of French Canadians toward this defeat, but also a glorious past for the French-Canadian seigneurs and other members of the upper classes, the anciens Canadiens who “appartenaient à une classe privilégiée, noble et distinguée” and "vivai[en]t dans "une fraternité bien touchante' avec un peuple de censitaires affectueux et reconnaissants" (Deschamps 5). ${ }^{94}$ La Corriveau's and François’s respective statuses evoke Brunet's divorce inévitable, wherein La Corriveau symbolizes social power and François represents the lower-class French Canadians. Jules affirms that in New France, witches are treated "avec tous les égards dus à leur haute position sociale” (de Gaspé 31). ${ }^{95}$ Scholars who study witchcraft and witch-hunts have noted that women of lower classes, especially old and poor women, were often targeted and accused of witchcraft (Hagen

\footnotetext{
${ }^{93}$ The split was actually more complex than how it is presented in Les anciens Canadiens through La Corriveau and François. In reality, there was a wide spectrum of reactions to British authority situated between La Corriveau's and François's diametrically opposing reactions. For example, in a later period just between 1838-1841, right after the Rebellions and the British government's establishment of an “"authoritarian' Special Council to govern the colony," there were eleven active French-Canadian newspapers, each "largely reflect[ing] their editors' outlook" on current political situations and events (Dagenais 28). In an attempt to categorize these newspapers' outlooks and ideologies, Maxime Dagenais broadly identifies three main categories. He writes, "generally speaking, 'loyalist' refers to newspapers that supported the Special Council, 'moderate' to those that opposed it occasionally but approved of its measures, and 'radical' refers to its most outspoken opponents" (Dagenais 28). Dagenais's nuanced analysis shows that responses and reactions to British authority during the transformative period in New France were more than clearly defined diametric oppositions.

${ }^{94}$ Belonged to a privileged class, noble and distinguished ... living in a 'touching fraternity' with a population of affectionate and appreciative tenants.

95 "In a manner fitting their power and social influence" (37, translated by Charles G.D. Roberts).
} 
387; Larner qtd. in Thurston 136; Walker 226). However, in her study of witchcraft in Scotland, Christina Larner "put[s] Scottish witches 'slightly further up the stratification scale' than the English ones who were at 'the bottom of the heap'—and, as she also point[s] out, some Scottish witches were of higher status still” (Yeoman 106). Josette Brun asserts that in New England, and similarly in New France but to a lesser extent, widows possessed a lot of social power and would consequently be accused of witchcraft as a result of the "malaise qui entoure le pouvoir des veuves" (49). ${ }^{96}$ She claims that many of the accused are women "(célibataires, mariées ou veuves) qui devaient hériter ou qui avaient hérité du bien familial en l'absence d'un héritier mâle dans leur famille immédiate. ... Le phénomène est demeuré marginal en Nouvelle-France, mais le veuvage y est sans doute, comme en France, considéré comme une boîte de Pandore" (Brun 49). ${ }^{97}$ La Corriveau, had she not been executed shortly after her husband's death, would have therefore been feared as a woman with such power. While Jules does not provide more information concerning the social status of witches in New France, or specifically that of La Corriveau, one could argue that these witches' power and social influence derive from the inhabitants' strong belief in witchcraft. From a historical perspective, "it was proverbial that the inhabitants of the Ile d'Orleans, in the St. Lawrence River near Quebec City [and more generally speaking, the inhabitants of New France], were inclined toward witchcraft. ... These legends and practices, and many others like them, had a

\footnotetext{
${ }^{96}$ Unease surrounding the power of widows.

${ }^{97}$ (Single, married, or widowed) who ought to inherit or have inherited family goods in the absence of a male inheritor in the immediate family. ... The phenomenon remained marginal in New-France, but widowhood was definitely, like in France, considered a Pandora's box.
} 
strong hold on the habitants, which lasted for centuries" (Pearl 45). Through his comment, Jules therefore reveals how witches in New France were regarded highly.

In contrast, François is most likely of a social status similar to that of his son, who wears a "costume ... à peu près celui des deux jeunes voyageurs [Jules et Arché], mais beaucoup moins riche" and who is "au service du capitaine d'Haberville ... [et] prend ses quartiers chez lui pendant la paix" (de Gaspé 12-13). ${ }^{98}$ Indeed, although there is little information about François, one can infer his social position from the information provided about his son José. José wears inexpensive clothing and works as a subordinate to the powerful Captain d'Haberville. Charles G.D. Roberts's adaptation of this particular passage is noteworthy since he translates "[il] prend ses quartiers chez lui pendant la paix" to "he occupies the place of a favored servant," highlighting the hierarchical divide between captain and servant that situates José in a lower position. The English version explicitly equates José to a servant in contrast to the original French text that does not specify in what capacity he is "au service du capitaine d'Haberville." Despite this discrepancy, José nevertheless embodies an ancien Canadien who incarnates "le peuple" (Biron et al. 125).

The fact that La Corriveau rides on François's back and identifies with the sorcerers demonstrates how she is a symbol of assimilation and acceptance by New France of British masters. The thematic of acceptance of the Conquest is also intrinsic to the novel's larger allegory involving Jules and Archibald. Indeed, even prior to La Corriveau and François's encounter, the opening pages of Les anciens Canadiens

\footnotetext{
98 "The dress ... is more like that of our young travelers [Jules and Archie], although much less costly. ... A follower of Captain d'Haberville ... in peace, he occupies the place of a favored servant" ( 15 , translated by Charles G.D. Roberts).
} 
establish cultural and class distinctions as the prevalent themes that will be dramatized throughout the novel. The reader is introduced to the two protagonists, Jules d'Haberville and Archibald Cameron of Locheill. Jules's physical appearance and movements “dénotent en lui l'origine française ... fils d'un seigneur, capitaine d'un détachement de marine de la colonie" (de Gaspé 11). ${ }^{99}$ This description suggests that his traits attest to his French origin, and that this origin is physically apparent. His ancestry resembles that of de Gaspé, whose father was the seigneur of Saint-Jean-Port-Joli before him, and whose grandfather had a career in the marine corps. Jules's hereditary nobility and upper-class status are presented as noteworthy characteristics that inherently define him.

Jules's friend, Archibald Cameron of Locheill, is also characterized by his cultural and social background. He is "a jeune montagnard écossais qui a fait ses études au collège des Jésuites de Québec. Comment, lui, étranger, se trouve-t-il dans une colonie française?" (de Gaspé 12). ${ }^{100}$ From the outset, the narrator describes Archibald as an outsider and alludes to his curious presence in a French colony. Despite this depiction of a stranger out of place in New France, Archibald claims a strong affinity with, and similarities to, the Canadian population. He thanks Jules and his peers, "dont les efforts constants ont été de faire oublier au pauvre exilé qu'il appartenait à une race étrangère à la vôtre!" (de Gaspé 14). ${ }^{101}$ Cardinal argues that “Arché occupe donc dans le récit une place éminemment stratégique, puisqu'il est à la fois l'ami et l'ennemi, le même et l'autre

\footnotetext{
99 "Proclaim his French blood. ... his father is one of the seigneurs, captain of a company in the colonial marine" (14, translated by Charles G.D. Roberts).

100 "A young Scotch Highlander who has been studying at the Jesuits' College in Quebec. How is it that he, a stranger, finds himself in this remote French colony?" (14, translated by Charles G.D. Roberts).

101 "Who have striven to make the poor exile forget that he belonged to an alien race" (17, translated by Charles G.D. Roberts).
} 
(en tant qu'il est à la fois un Franco-Écossais plutôt encanadianisé et, éventuellement, un sujet et soldat de Sa Majesté britannique)" (20). ${ }^{102}$ The protagonists therefore embody two differing figures: a French-Canadian pure-laine of noble descent, and an outsider who feels a sense of belonging to French Canada, or paradoxically an insider of a "race étrangère."

Echoing Cardinal's observation that Archibald is at once 'l'ami et l'ennemi, le même et l'autre," Biron et al. argue that "deux cultures, deux époques s'affrontent à travers [Arché] : celles des anciens et des nouveaux Canadiens. Entre elles, la distance s'est creusée au point qu'elles ne semblent plus tout à fait conciliables" (127). ${ }^{103}$ While Biron et al. correctly note this split, even more significant than Archibald's condensation of two different types of Canadiens is the way his cultural background informs the transformation of the old Canadien into the new. Due to Arché's Scottish background, scholars including Cardinal and Raudsepp interpret the character as offering a basis of comparison between Scotland and New France for the novel. In drawing on the history between Scotland and England, specifically Scotland's integration into the United Kingdom of Great Britain, de Gaspé anticipates and advocates for New France's allegiance to Britain following the Conquest of 1760. Indeed, subsequent to Archibald's introduction, the second chapter of the novel is dedicated to providing a brief context of Scotland during the Jacobite rising of 1745, which culminated in the decisive Battle of Culloden in 1746. This battle was fought between the British government and the

\footnotetext{
${ }^{102}$ Archie therefore occupies an eminently strategic place in the novel, since he is at once the friend and the enemy, the same and the other (since he is at once a rather Canadianized Franco-Scot, and eventually, a subject and soldier of Her British Majesty).

103 Two cultures, two eras clash through [Archie]: those of the old and new Canadiens. Between them, a distance has been dug to the point that they no longer seem quite reconcilable.
} 
Scottish Jacobites. ${ }^{104}$ Approximately thirty years prior, the English and Scottish

Parliaments passed the Acts of Union of 1707 which led to the unification of the

Kingdom of England and the Kingdom of Scotland through the creation of the United

Kingdom of Great Britain. The Jacobites strongly opposed the Union and fought in the Battle of Culloden because they "dream[ed] of a Stuart restoration and the rebirth of an independent Scotland" (Szechi 359).

The Jacobites, including Archibald's father in de Gaspé's novel, were defeated and "un long gémissement de rage et de désespoir parcourut les montagnes et les vallées de l'ancienne Calédonie! Ses enfants durent renoncer pour toujours à reconquérir une liberté pour laquelle ils avaient combattu pendant plusieurs siècles avec tant d'acharnement et de vaillance" (de Gaspé 16). ${ }^{105}$ This description speaks to the Scots' valour, rage, and frustration, but more importantly to the impossibility of regaining their freedom. While the aforementioned sentiments evoke defeat and resignation, they are immediately undercut in the following lines. The Scots are no longer upset because they can bathe in Britain's glory:

l'Ecosse, partie intégrale, maintenant, d'un des plus puissants empires de l'univers, n'a pas eu lieu de déplorer sa défaite. Ses anciens ennemis s'enorgueillissent des travaux de ses littérateurs; et ses hommes d'état ont été aussi célèbres dans le cabinet de leur souverain que leurs guerriers en combattant pour leur nouvelle patrie. Tandis que leurs frères de la verte Erin, les Irlandais au

\footnotetext{
104 The Jacobites fighting in the Battle of Culloden were mostly, but not exclusively, Scottish. There were also English, French, and Irish recruits.

105 "A long cry of rage and despair went up from the hills and glens of Old Caledonia. Her children were robbed of their last hope of winning back a freedom for which they had fought through centuries of desperate valor" (19, translated by Charles G.D. Roberts).
} 
cœur chaud et généreux, frémissent encore en mordant leurs chaînes, eux, les

Ecossais, jouissent en paix de leur prospérité. (de Gaspé 16, italics mine) ${ }^{106}$

Although Scotland was already part of the United Kingdom of Great Britain as a result of the Union of 1707, the Scots' defeat at the Battle of Culloden cemented this union and the inevitable subsumption of Scottish writers, politicians, and warriors into 'l'un des plus puissants empires de l'univers." Based on de Gaspé's descriptions, by accepting this union, the Scots can assuredly live in peace and prosperity. De Gaspé's comparison of Scotland and Ireland reveals two possible outcomes for French Canada following their defeat at the hands of the British, either their "integrat[ion] into the empire like the Scots" or their pursuit of "the path of resistance [as] chosen by the Irish" (Raudsepp 110).

Raudsepp argues that de Gaspé's position on this matter is evident, for "while it is readily apparent that he feels a tug at his heartstrings when contemplating the romantic, but essentially tragic, resistance of the Irish, it is equally clear that it is the more pragmatic approach of the Scots that meets with his approval" (110). Cardinal similarly affirms, “comment ne pas lire, en effet, que les Canadiens, tout comme les Écossais, pourraient fort bien s'épanouir dans le cadre du régime britannique? Comment ne pas entendre que la rébellion, irlandaise ou canadienne, ne saurait aboutir qu'à un chemin de larmes et de mort?" (20-21). ${ }^{107}$ He suggests that de Gaspé's descriptions of the Scottish

\footnotetext{
106 "Scotland, now become an integral part of one of the mightiest empires of the world, has had no room for grieving at her defeat. Her ancient enemies have made boast of the achievements of her poets and writers, and her statesmen have been as distinguished in the councils of their sovereign as her warriors in fighting for their new fatherland. While their brothers in green Ireland yet groan and gnaw their chains, the Scotch rest happy in their prosperity and their peace" (19, translated by Charles G.D. Roberts, italics mine).

${ }^{107}$ How can we not read, in fact, that the Canadiens, much like the Scots, would most likely prosper in the framework of the British regime? How can we not hear that the rebellion, Irish or Canadian, would only lead to a road of tears and death?
} 
and Irish contexts are more or less explicit pleas "pour la réconciliation des Canadiens avec le pouvoir britannique" (Cardinal 20-21). ${ }^{108}$ Archibald therefore embodies the collective national defeat of the Scots and the imminent prosperity of the nation in a way that anticipates La Corriveau's symbolism. Indeed, the characters are doubles: Archibald and La Corriveau both have French-Canadian and Scottish roots (La Corriveau through Burns's “Tam O'Shanter”); they both embody nationally decisive battles against Britain; and they both show their allegiance to Britain, Archibald as a soldier of the British military and La Corriveau through her desire to reach the English fiends on the Île d'Orléans. Together, they allegorize the parallel narratives of Scotland and New France. In addition to La Corriveau and Archibald possessing French-Canadian and Scottish identities, they both possess affinities with Indigenous peoples. This existing connection between the three cultures and peoples calls into question more than EnglishFrench relationships in nineteenth-century Canada, especially as it allows French Canadians to assume the role of the colonized Indigenous peoples in their defeat by British officers. Indeed, de Gaspé's use of a triangular relationship between French Canadians, Scots, and Indigenous peoples raises questions concerning the treatment of Indigenous peoples as internal others; the relationship between English Canadians, French Canadians, and the Abenaki; and the future of New France in comparison to Scotland after British conquest. When, on the Île d'Orléans, La Corriveau threatens François, “tous les sorciers s'arrêtent et poussent trois cris, trois hurlements, comme font les sauvages quand ils ont chanté et dansé 'la guerre,' cette danse et cette chanson par

\footnotetext{
${ }^{108}$ For the reconciliation of Canadians with British power.
} 
laquelle ils préludent toujours à une expédition guerrière" (de Gaspé 44). ${ }^{109}$ The comparison between the sorcerers and the Indigenous people through the battle cries extends to La Corriveau who wants to join them to sing and dance, and is further substantiated through the analogous chapters, "Une nuit avec les sorciers" and "Une nuit avec les sauvages," which confirm the relationship between the sorcière, La Corriveau, and the Abenaki people. The latter chapter relates Archibald's kidnapping by the Abenaki and the night he spends as their prisoner. During his imprisonment, he meets Dumais, the man he saves during the ice break-up (the débâcle), and who now tries to save him in return by convincing one of the kidnappers to sell him the prisoner.

Witches, Scots, and Indigenous peoples in the novel all prefer being burned to being hanged; whereas Jules comments to Archibald that "vous les brûlez [les sorcières] en Écosse" (de Gaspé 31), Dumais tells the kidnapper Grand'Loutre, “un Guerrier écossais aime mieux être brûlé que pendu. Il pense, comme les peaux rouges du Canada, qu'on ne pend que les chiens, et que s'il visitait le pays des âmes la corde au cou, les guerriers sauvages ne voudraient pas chasser avec lui” (de Gaspé 171). ${ }^{110}$ The latter confirms this claim, asserting that "ils [les Anglais] nous auraient remerciés de les pendre : il n'y a que le guerrier sauvage qui préfère le bûcher à la honte d'être pendu comme un chien" (de Gaspé 171). ${ }^{111}$ Grand'Loutre's comment demonstrates that being burned at the

\footnotetext{
109 "All the goblins halted and gave three yells, three frightful whoops, like the Indians give when they have danced that war-dance with which they always begin their bloody expeditions" (52, translated by Charles G.D. Roberts).

110 "In Scotland you burn them [the witches] ... a Scotch warrior prefers being burnt to being hung. Like the red-skins of Canada, he thinks that it is only dogs who ought to be hung, and that if he visited the land of spirits with a rope round his neck, the Indian warriors would refuse to hunt with him" (37, 185 translated by Charles G.D. Roberts).

111 "They [the English] would have thanked us to hang them. It is only the red warrior who prefers the stake to the disgrace of being hung like a dog" (184-85, translated by Charles G.D. Roberts).
} 
stake is more respectable than being hanged, an honour to which the English are not privy, but that Dumais extends to Scots. Dumais argues that Indigenous people and Scots think alike and implies that they even hunt together in an afterlife, but only if the Scot is burned. Indeed, he even goes as far as to say that "les Écossais sont les sauvages des Anglais" (de Gaspé 171), directly associating Scots to Indigenous people. ${ }^{112}$ As Cardinal astutely claims, this parallel between Scots and Indigenous peoples suggests that the Scots “occupe[nt] la même place symbolique que lui [l’Amérindien] face au conquérant anglais" and that as such, both are "une collectivité ayant lutté vaillamment pour sa liberté, sa survie" (60). ${ }^{113}$ La Corriveau's subtle association with the Indigenous people through the sorcerers' war cries and dance, as well as their burning at the stake, therefore positions French Canadians and Indigenous peoples as analogous. All three peoples are presented as minority groups struggling for their liberty and survival against British rule. Cardinal argues that "la condition politique du minoritaire (ou du vaincu)—qu'il soit Amérindien, Canadien ou Écossais — en est une fort précaire qui, faute de compromis politique, peut conduire à la mort, à la complète disparition du peuple" (60-61). ${ }^{114}$ In this sense, de Gaspé's novel encourages political compromise between French Canadians (and arguably all other minority groups) and the British officers in order to ensure the smooth transition of New France's shift from French to British rule.

\footnotetext{
112 "The Scotch are the savages of the English" (185, translated by Charles G.D. Roberts).

113 Occupy the same symbolic imaginary in the face of the British conquerors as the Indigenous person ... a collective that fought ardently for its freedom, its survival.

114 The political condition of the minority (or the vanquished) — whether it be Indigenous, Canadian, or Scottish - is a highly precarious one that, without political compromise, could lead to death, to the complete disappearance of a people.
} 


\subsection{The Flexible Strategy of terra nullius in The Golden Dog}

Kirby's The Golden Dog (1877) similarly advocates for political compromise between French Canadians and British officers. ${ }^{115}$ However, unlike de Gaspé, Kirby's political stance is informed by his English cultural background. Whereas de Gaspé's nationalist sentiments were strongly intertwined with his desire to preserve aristocratic power in French Canada, Kirby "believed he was drawing English and French communities together by stressing the superiority of Quebec peasants over the aristocrats who had gone home to France" (Fulford). The Golden Dog differs from Les anciens Canadiens in that it functions strictly in the tradition of English-Canadian romantic nationalism. Kirby was fundamentally a “"tory loyalist' ... But he was also a Canadian nationalist with progressive ideas about the future of Canada as a bicultural, bilingual country whose heritage included that of both England and France" (M.J. Edwards, "Kirby, William"). Canada, he hoped, would continue to be free from the United States, instead favouring strong relations with Britain. He believed that Britain's "empire formed, then, part of a coherent plan to assure the present survival and future independence of a 'glorious' Canadian nation" (M.J. Edwards, "Kirby, William”). In this

\footnotetext{
115 The first edition of The Golden Dog was published by Lovell, Adam, Wesson \& Company in 1977. According to Elizabeth Brady, this edition provides the most authoritative text in terms of what Kirby intended. However, there are many typographical errors. The second edition published by L.C. Page and Company in 1897 is considered "authoritative" to the extent that it "was the last edition printed in Kirby's lifetime" (Brady 46). While Kirby did make minor emendations, the text is abridged and the publisher made significant changes to the text that Kirby did not authorize (Brady 47). Subsequent editions were further removed from Kirby's original intentions. Indeed, since its first publication The Golden Dog has been edited and reprinted multiple times, and even translated into French. In the introduction to her scholarly edition of the work, Mary Jane Edwards explains that she used the manuscript that was held in the Kirby Collection at the Archives of Ontario as the main copy-text for the Centre for Editing Early Canadian Texts (CEECT) edition and when its leaves were missing or unreadable, she used the Lovell, Adam, Wesson \& Company edition of this manuscript to supplement her copy-text (M. J. Edwards, "Editor's Introduction" cxxxix-cxl). I use Edwards's version of the text for my literary analysis.
} 
sense, his political leanings, although certainly much more loyalist than de Gaspé's, share the latter's desire to promote a bicultural and bilingual Canada.

Similarly to Les anciens Canadiens, The Golden Dog is set in New France around the time of the British Conquest. This novel narrates the downfall of New France as a result of the corruption and immorality of the Ancien Régime and the incompetence of characters including King Louis XV, his mistress Madame de Pompadour, and New France's leader Intendant François Bigot. There are many interrelated plotlines, one of which is about the Intendant Bigot, who keeps a secret métisse mistress named Caroline in his haunted castle called Beaumanoir. However, his current love interest, Angelique de Meloises, wants to win his heart entirely and calls upon La Corriveau to assassinate her rival. Other plotlines revolve around Le Gardeur de Repentigny, a kind person who is in love with Angelique de Meloises and easily influenced by the Grand Company that convinces him to join them in inappropriate activities such as excessive drinking, gambling, and talking sinfully about women; Amelie de Repentigny, Le Gardeur's kindhearted sister who is in love with Pierre Philibert, whose father owns the Golden Dog; and the Philibert family, Pierre and his father Le Bourgeois, who protect the people living in the colony in the name of justice, exchange goods for what they are worth, donate products to the poor, and wish everyone well. ${ }^{116}$

Working in the gothic mode, Kirby's novel deliberately imports "the European Gothic tradition into a Canadian context" and, as Sugars argues, serves as "a demonstration of how imported cultural forms have a debilitating effect on indigenous

\footnotetext{
${ }^{116}$ The Grand Company is a group consisting of Bigot and his peers who work for the King of France and who monopolize all trades and sales in the colony with the exception of the Golden Dog store.
} 
colonial cultures/societies, since the 'imported' Gothic characters (Bigot, La Corriveau) have a destructive effect on the local culture. The imported Gothic menace becomes a materialization of inauthentic cultural imperialism" (Canadian Gothic 89). Sugars correctly notes that Bigot and La Corriveau are imported gothic characters, both possessing French origins (La Corriveau's mother and grandmother were French, and the former moved to the New World where she married the Sieur Corriveau and had her daughter, La Corriveau). However, I contend that the figure of La Corriveau can also paradoxically be treated as a figure that is proper to the locale, born and raised in New France. This paradox arises from the novel's adherence to the gothic romance mode (rather than strictly romance), which creates contradictions within the narrative. As Robert Stacey notes, "this idea of contamination followed by creeping decay from the inside [i.e., Bigot, La Corriveau] marks a departure from the structure of romantic agon — conceived as a pitched battle between the forces of good and evil—in the direction of the gothic's uncanny, whose false appearances and categorical confusions tend to make such clear distinctions problematic" (100, italics in original). ${ }^{117}$ Read in this way, with La Corriveau symbolizing an internal force of destruction proper to the locale, Kirby's novel can be understood as presenting French Canadians and Indigenous peoples as self-destructive, declining races. I examine how La Corriveau's direct involvement in the violent assassination of Caroline de St Castin creates an artificial terra nullius wherein the erasure of French Canadians and Indigenous peoples authenticates the

\footnotetext{
${ }^{117}$ See Stacey's “Romance, Pastoral Romance, and the Nation in History: William Kirby's The Golden Dog and Philippe-Joseph Aubert de Gaspe's Les Anciens Canadiens" wherein Stacey examines form in de Gaspé's and Kirby's works. He argues that while the novels both ascribe to the mode of romance, there are important differences between the two as Les anciens Canadiens is, in essence, a pastoral romance, whereas The Golden Dog ascribes more to a gothic romance.
} 
presence of English Canadians as the "real" Indigenous peoples in the Canadian landscape. In other words, Kirby situates minority groups including French Canadians, Indigenous peoples, and Acadians as mutually destructive and disappearing, giving way to the British conquest. By doing so, Kirby removes any malevolence or guilt from the British characters and thereby sets up the foundation for a harmonious, bicultural and bilingual Canadian nation-state. Although there is perhaps less ambiguity in The Golden Dog than in de Gaspé's work regarding the type of French-English relations in Canada for which the author advocated, I ultimately want to suggest that Kirby's use of the gothic mode inevitably leads to a subtle and inadvertent critique of English-Canadian romantic nationalism at the end of the novel.

Akin to de Gaspé's use of Scottish historical material, Kirby draws on Acadia's long history of oscillation between French and English rule, which culminated in England's definitive possession of the colony as a result of the Treaty of Utrecht that brought a close to the War of Spanish Succession (1701-1713), to insinuate New France's inevitable absorption into the British Empire. ${ }^{118}$ Keeping in mind that the story of The Golden Dog begins in 1748, the novel presages two momentous events in Acadia's and New France's histories - the Great Expulsion of Acadians in 1755 and the Defeat at the Plains of Abraham in 1759. The first chapter, entitled "Men of the Old Régime," foreshadows the decline of the old regime by establishing in the opening pages the similarity of the fates of French Canada and Acadia. The narrator recounts how "the English, who now overran Acadia, ... began to threaten Quebec with invasion by sea and

\footnotetext{
${ }^{118}$ While 1713 is the official date of the Treaty, Acadia's capital Port-Royal was captured by New England in 1710 during the Siege of Port-Royal.
} 
land" (Kirby 4). Since the seventeenth century, Acadia had been at the heart of various sociopolitical struggles between the French, English, Acadians, and the Wabanaki Confederacy, the latter comprising Penobscot, Passamaquoddy, Mi'kmaq, Maliseet, and Abenaki peoples. ${ }^{119}$ John Douglas Belshaw explains how some of these relations were intrinsically intertwined. For example, the Wabanaki Confederacy "grafted the Acadiens onto their lives and struggles. Faced with aggressive British settlements in New England, the Confederacy accepted French fortifications and support" (Belshaw, Canadian History: Pre-Confederation). In other words, the French, Acadians, and Wabanaki worked together to fend off British invasion.

As "one of the foremost of the royal officers in Acadia" (Kirby 78), Bigot embodies the potential of military and diplomatic alliances between the French, the Wabanaki Confederacy, and the Acadians. The latter, like the French, were "predominantly French-speaking and Catholic" (Griffiths, "The Golden Age" 22). Even though Acadia was permanently transferred to English control as a consequence of the Treaty of Utrecht, the Acadian population was unaware of this fact at the time and had a "fundamental belief in the mutability of power, [a] dominant sense of the probability of alternate French and English control of the colony, [which] became the cornerstone of Acadian politics during the years 1713 to 1748" (Griffiths, "The Golden Age" 23). Bigot's promise to marry Caroline would have associated him, a symbol of France in the novel, with "the only daughter of the noble house" who "had been reared in all the

\footnotetext{
119 Although Acadians were indeed colonists of French heritage, as Naomi Griffiths explains, "at the opening of the seventeenth century there were no Acadians, but by the close of that century there were people, living in territory known internationally as 'Acadia or Nova Scotia,' essentially present-day Nova Scotia, New Brunswick, and Prince Edward Island, who considered themselves to be first and foremost Acadians rather than members of any other group" (From Migrant to Acadian xv).
} 
refinements and luxuries of the period, as became her rank and position both in France and her native Province" (Kirby 78). Caroline is an "Acadienne of ancient and noble family, whose head and founder the Baron de St Castin had married the beautiful daughter of the high chief of the Abenaquis" (Kirby 78). Bigot and Caroline's marriage would have therefore solidified the bonds between the three peoples who have as a common enemy the British soldiers. However, Carl Murphy rightfully observes that “marriage, or rather its absence, is a key metaphor in Kirby's novel. It is the inability of characters to marry and the subsequent collapse of their personal relationships which become the metaphors for the collapse of New France" (Murphy). Bigot's failure to marry Caroline and his immediate retreat from Acadia mirrors France's failure to keep Acadia from the hands of the British. Bigot "left Acadia a conquered Province in the hands of the English" and "he also left behind him, the one true loving heart that believed in his honor, and still prayed for his happiness" (Kirby 79-80). This failure not only disrupts the alliances between the French, Wabanaki Confederacy, and Acadians, but also leads — at least partially — to the reconfiguration of the power dynamics of Acadia in favour of the English and the subsequent Great Expulsion.

Caroline's desperate attempt to win over Bigot serves as a microcosmic demonstration of Acadia's own desire to remain allied with France. During their courtship, Bigot's "ready wit and graceful manners pleased and flattered the susceptible girl, not used to the seductions of the polished courtiers of the Mother land of France.... She trusted his promises as she would have trusted God's ... and counted as a gain, every loss she suffered for his sake and for the affection she bore him" (Kirby 78-79). Caroline's faith in Bigot and susceptibility to the seductions of the motherland of France 
mirrors how "hundreds if not thousands [of Acadians] had abandoned neutrality and sworn loyalty to France. Indeed, many of the British settlers brought in by [Edward] Cornwallis and his successor ... deserted the British and joined the Acadians and the French" (Belshaw, Canadian History: Pre-Confederation). The novel explicitly offers a parallel between Acadia and New France, with Acadia's desire to support and be supported by France mirroring New France's same desires but ultimate abandonment by the mother country. During the Defeat at the Plains of Abraham, "the noblesse and people of New France" experienced "their final abandonment by the Court of France. They knew they had been coldly, deliberately, cruelly deserted by their King” (Kirby 748). Unlike Les anciens Canadiens, The Golden Dog does not demonize the British soldiers, but rather Bigot, who is responsible for the downfall of New France. While "Satan is bold ... he would blush in the presence of Bigot" (Kirby 148). The Intendant is also "a devil more powerful than the one [La Corriveau and her associate Mère Malheur] serve" (Kirby 527). As a powerful devil-like being and an embodiment of the Ancien Régime, he is an obstacle to Britain's capture of New France.

Kirby faults Bigot with the downfall of New France, but instrumentalizes La Corriveau in this destruction, particularly in Caroline's destruction. The character of La Corriveau is first introduced when Angelique des Meloises concocts a plan to kill her rival, Caroline de St Castin. Angelique summons her maid, Fanchon Dodier, with the premise that she lost her jewels at Intendant Bigot's ball and needs help locating them. Fanchon explains that while this may not be a suitable solution for "ladies who can read and write and who have the wisest gentlemen to give them counsel" (Kirby 399), many habitant girls would seek help from her Aunt Josephte Dodier, also known as Dame 
Dodier, Marie Josephte, and more commonly La Corriveau. She relates that her aunt is a "terrible woman" and that villagers "tremble when she looks at them with her black evil eye" (Kirby 400). Angelique's response is particularly striking as she asks, "but is it not wicked? Is it not forbidden by the Church to consult a woman like her, a sorciere!" (Kirby 400). The evocation of a sorcière recalls de Gaspé's own version of La Corriveau. While Kirby's Corriveau figure is mostly known as a poisoner, this characterization demonstrates Kirby's indebtedness to de Gaspé for the first literary portrayal of La Corriveau.

Here, too, La Corriveau is an anti-Catholic figure. When discussing with her friend Mère Malheur, La Corriveau says that when she goes to church, she "whisper[s] [her] prayers backwards, to keep on terms with the Devil, who stands nodding behind the altar, to every one of [her] petitions" (Kirby 528). Anti-Catholicism, while a common theme in British gothic fiction, must be re-examined in a Canadian context; indeed, while British society was mainly Protestant, Canada saw divisions between Protestant English Canadians and Catholic French Canadians. One of the characters in The Golden Dog, Chevalier La Corne St Luc, even swears his permanent faith in Catholicism in the face of other religions when he asserts, "the only thing I will admit... is the certainty that come what may, loyal and Catholic New France will never join hands with the heretical Puritans of New England" (Kirby 469). In regard to this emphatic division, Sugars claims that "the anti-Catholicism that features so prominently in the British Gothic tradition is tempered in Anglo-Canadian Gothic renditions of French Canada" (Canadian Gothic 79). Portrayals of French-Canadian Catholicism in such works relate to "superstition and simplicity, but less with malevolence or corruption” (Sugars, Canadian Gothic 79). 
Although British gothic fiction usually draws upon debauched monks, priests, and nuns as anti-Catholic embodiments, Kirby strictly associates elements symbolizing the Ancien Régime—namely La Corriveau and Intendent Bigot—with anti-Catholicism.

Anti-Catholicism characterizes La Corriveau in both de Gaspé's and Kirby’s works. Whereas La Corriveau could not cross the blessed Saint Lawrence river and convene with the devil on the Île d'Orléans in Les anciens Canadiens, in Kirby's novel, any interaction between La Corriveau and the villagers is forbidden by the church. Such forbiddance reveals the extent to which La Corriveau contravenes religious integrity. The villagers' fear of La Corriveau supersedes their faith in religion. Kirby paradoxically attacks the Catholic Church by presenting La Corriveau first as having a role equivalent to that of a bishop, and second as having powers that exceed those of the religious institution. Fanchon asserts that La Corriveau "is equal to a Bishop for stirring up piety and more Ave Marias are repeated when she is in [the boatman Antoine La Chance's] boat than are said by the whole Parish on Sunday" (Kirby 402). Much like Jules d'Haberville's witches who hold much power and social influence in New France, Dame Dodier holds an equally high position to that of a bishop, a figure of high rank in the Christian Church. And yet, women and men rally around Dame Dodier since she can perform greater feats than the Church. For instance, she can "tell a poor girl about her sweetheart and how to keep him in hand" when "the clergy cannot" (Kirby 400). Indeed, "there was something sublime in the satanic pride with which she carried with her the terrible secrets of her race" (Kirby 411).

Much like her equation to the position of the Bishop in the Catholic Church, Dame Dodier assumes an equivalently venerated position in Indigenous culture. The 
Indigenous people call her "the old medicine woman" (Kirby 415), but rather than “[provide] medical leadership" and doctor sick patients as medicine men and women do (Lake 1), she can make "sickness settle like a fog upon the wigwams of the Red men" (Kirby 416). The Indigenous people's behaviours resemble those of the French Canadians who cross themselves when speaking of the witch; the Indigenous people "st[and] in awe of the far reaching power of [La Corriveau] from the spell of whose witchcraft, they firmly believed no hiding place even in the deepest woods could protect them" (Kirby 416). French-Canadian habitants and Indigenous people are thus conflated through their superstitious natures. When Fanchon meets with the Indigenous people so that they can bring her by canoe to La Corriveau's home, one of the Indigenous characters mentions that "the Habitans [sic] say she [La Corriveau] talks with the Devil" and is described as having "picked up this piece of superstition from the white Habitans [sic], and like them thoroughly believed in the supernatural powers of La Corriveau” (Kirby 416).

By portraying La Corriveau as a character conflating French-Canadian and Indigenous attributes, Kirby simplifies the task of eliminating or assimilating that which is "indigenous" to the locale in his novel to facilitate, in turn, the indigenization of English Canadians. Yet, reading Kirby's novel with an emphasis on his portrayal of La Corriveau, one can also see contradictions inherent in his intertwining of the conventions of the gothic with the thematics of settler colonialism. At a first glance, Kirby's version of the legend, rather than elucidating the British soldiers' involvement in the bloody conquest that dispossessed French Canadians, invites a reading of La Corriveau's assassination of Caroline as a symbolic confession of French-Canadian complicity in the violence inherent to a settler-colonial society — the founding violence of colonial 
settlement that Cornellier, St-Amand, and Couture-Grondin argue is often neglected in Québécois scholarship. Kirby's text, in other words, unwittingly exposes French Canada's role in the dispossession of Indigenous people in its own violent creation of a nation-state prior to the British's attempt to do the same with the French Canadians. While La Corriveau was supposed secretly to poison the métisse, she succumbs to her impulses and violently assassinates her instead. Even after "Caroline lay dead, dead beyond all doubt, never to be resuscitated," La Corriveau stabs her again, watching as "a faint trickle of blood in red threads, ran down the snow white vestment, and that was all! The heart had forever ceased to beat, and the blood to circulate. The golden bowl was broken and the silver cord of life loosed forever" (Kirby 546-47). This description of La Corriveau stabbing Caroline post-mortem symptomatically allegorizes the colonial violence in which French Canadians are complicit.

However, at a second glance, this assassination acquires a different significance if one considers the conflation of French-Canadian and Indigenous cultures through the figure of La Corriveau. Terry Goldie asserts, “in their need to become 'native,' to belong in the land, whites in Canada have required a process I have termed 'indigenization,' the impossible necessity of becoming indigenous" (194). This indigenization process, he explains, can mainly be done in two ways: "the white culture might reject the indigene, by stating that the country really began with the arrival of the whites, an approach no longer popular but significant in the nineteenth and early twentieth centuries. Or else the white culture can attempt to incorporate the Other" (Goldie 194). In the context of The Golden Dog, the "whites in Canada" and "white culture" can even be narrowed down to English Canadians, whose indigenization depended on the rejection of both the 
Indigenous people and the French Canadians who were present on the land prior to the arrival of English settlers. The indigenization of French Canadians through their resemblance to Indigenous people is thus a necessary step toward their elimination, which will consequently allow English Canadians to become fully indigenous to the land afterwards.

As a gothic figure, La Corriveau more closely resembles the threatening Indigenous person than the typical European gothic threat, possessing characteristics of both the "Indian maiden" and "Indian warrior." E. Pauline Johnson notes that nonIndigenous writers often portray the stereotypical "Indian girl of fiction" as being "fireeyed" and "crouching" (6). Kirby describes La Corriveau as having similar characteristics throughout the novel, especially in the passages surrounding Caroline's assassination. When fetching the infamous poison called Aqua Tofana, La Corriveau walks "with her quiet tiger like tread" (Kirby 425). On the night she kills Caroline, she is a "dark figure of a woman mak[ing] her way swiftly and cautiously towards the Chateau" (Kirby 532). She "glides onwards" (Kirby 532) and "emerge[s] stealthily out of the forest. Crouching on the shady side of the high garden hedges" (Kirby 534). And again, when she leaves after the evil deed has been accomplished, "she crept like a guilty thing under the shadow of the hedge" and "glided like a dark spectre through the forest of Beaumanoir" (Kirby 549). La Corriveau's stealth, silence, and darkness liken her to both Indigenous maidens and spectral figures — or more precisely, Indigenous spectres. ${ }^{120}$ This Indigenous spectrality "textualize[s] a form of White history which cast colonized or invaded peoples

\footnotetext{
${ }^{120}$ Just to provide one example, Winona in Isabella Valancy Crawford's Winona; or, The Foster-Sisters (1873) is an Indigenous character who is often described as phantom-like (Crawford $261)$, gliding spectrally across the floor $(141,153)$.
} 
and the colonial landscape as a ghostly or monstrous threat to the civilised (White) world" (Sugars, Canadian Gothic 22). La Corriveau thus becomes an "Indigenous" spectre that doubly haunts the nation; she evokes "a form of transgenerational haunting that is inherently political" (J. D. Edwards xxix) that will memorialize Indigenous dispossession and the French Canadians' defeat at the Plains of Abraham.

La Corriveau's conformity to both the "Indian maiden" and "Indian warrior" stereotypes further concretizes her indigeneity. She breaks from the strict conventions of the "Indian maiden" by demonstrating a "lack of submissiveness, powerful passions, and resolute action, attributes more commonly associated with the image of the 'savage' warrior than that of Indian maiden" (Early and Peterman 47). She lacks submissiveness as she radically deviates from her employer's assassination plan and succumbs to her powerful passions. At the sight of Caroline's dead body, La Corriveau "was at this moment like a pantheress that has brought down her prey and stands over it to rend it in pieces" (Kirby 546). She then "plucked the sharp Italian stiletto from her bosom and with a firm heavy hand plunged it twice into the body of the lifeless girl" (Kirby 547). More generally, when the narrator recounts La Corriveau's genealogy, he emphasizes that her soul seems to be "calling for revenge upon the whole race of the oppressors of her family as she regarded the punishers of their crimes" (Kirby 410). Her desire for revenge upon a whole a race of oppressors evokes the "vengeful Indian warrior" trope.

Northey argues that Kirby's Corriveau figure "represents the manipulative intelligence and its inhumane possibilities" and is consequently "not nearly as culturally threatening as the more pure spiritual evil she represents in Aubert de Gaspé's rendition" (31), but the poisoner is in fact extremely culturally threatening and her portrayal as an 
Indigenous person complicates the imminent British Conquest of New France. As Justin D. Edwards argues,

to place the Native North American in the position of bloodthirsty savage is to articulate deep-seated fears about the otherness of the non-European. Such positioning fulfills the goals of colonial enterprise by justifying land acquisition and displacement. That is, by equating "nativeness" with animalism and monstrosity, the European settler could pretend that the land was void of humanness and thus appropriate it without guilt or shame. (112)

The narrative of the bloodthirsty savage was not uncommon in the nineteenth century. However, by placing La Corriveau in the position of a bloodthirsty savage, Kirby also positions French Canadians as a threatening, non-European other. In other words, in applying Edwards's claim concerning the European/non-European binary opposition here, English settlers would be considered "European," which in this context, has a resounding synonymity with what Daniel Coleman calls the British model of civility. ${ }^{121}$ The French-Canadian settlers would therefore be deemed "non-European" because they do not ascribe to such model of civility. Indeed, if La Corriveau truly is a "gothic import" from the French mother country, she evokes the "deep-seated fears" relating to the corruption of the Ancien Régime. However, as a witch born and raised in Saint-Vallier, she also emblematizes the French Canadians who are obstacles to the English settlers' envisioned terra nullius. Whether Kirby intended her to be an import from the Old World or a symbol of the New World, she remains an oppositional force to the English colonizers who wish to claim New France for themselves.

\footnotetext{
${ }^{121}$ See Coleman's White Civility: The Literary Project of English Canada (2006).
} 
La Corriveau's and Caroline's intertwined gothic plotlines provide the ideal scenario for English Canadians to appropriate the land "without guilt or shame" (J. D. Edwards 112); the French-Canadian and Indigenous characters are presented as selfdestructive, and their declining races give way to the British conquest. When Angelique shares her knowledge of Caroline's existence with her friend Amelie, she explains that the métisse "was a lady of noble family in Acadia, which had mingled its Patrician blood with that of the native Chiefs and possessors of the soil" (Kirby 38). She recognizes Indigenous people as the "possessors of the soil" in a passing comment, but these few words gain ample significance as she hires La Corriveau to kill Caroline and undoubtedly end the latter's noble family line. In ways that recall the "Indigenous" and spectral Corriveau figure, Caroline has a "weeping Madonna like face, which haunts the ruins of Beaumanoir to this day" (Kirby 78). She has "eyes of that dark luster which reappears for generations in the descendants of Europeans who have mingled their blood with that of the Aborigines of the forest. The Indian eye, is preserved as an heir loom [sic], long after all memory of the Red stain has vanished from the traditions of the family" (Kirby 78). Her haunting face, and especially the "vanishing" red stain, foreshadow her decline and that of her Abenaki kin by the end of the novel.

The title of Kirby's last chapter, "The Mills of God Grind Slowly," refers to the expression "the mills of the gods grind slowly, but they grind small," which signifies that "justice is often a slow process, but it is inevitable" (Mieder 50). The ending of the novel recounts two inevitable major events: the consequences of the Seven Years War and La Corriveau's demise. The war concludes with 
Montcalm [who,] after reaping successive harvests of victories, brilliant beyond all precedent in North America, died a sacrifice to the insatiable greed and extravagance of Bigot and his associates, who while enriching themselves, starved the army, and plundered the colony of all its resources. The fall of Quebec and the capitulation of Montreal were less owing to the power of the English, than to the corrupt misgovernment of Bigot and Vaudreuil, and the neglect by the court of France of her ancient and devoted colony. (Kirby 745-46)

Although the population feared the British soldiers and their arrival in New France throughout the narrative, these enemies remained largely absent until now, finally appearing at the end to rescue the French-Canadian population. Significantly, by this time, they are no longer the French Canadians' enemies. In 1777, “the red uniform of her army was loyally worn by the old but still indomitable La Corne St Luc, who with the De Salaberrys, the De Beaujeus, Duchesnays, de Gaspes, and others of noblest name and lineage in New France, had come forward as loyal subjects of England's crown" (Kirby 747). The French-Canadian combatants willingly pledge their allegiance to Britain. Whereas de Gaspé’s “sorciers sur 1'île” were described as “soldats anglais dans leur uniforme particulier" (Lasnier 88) and Montgomery, leader of the British army, was a demonic being, Kirby's English soldiers are presented as heroes for saving the FrenchCanadian habitants from the corrupt Ancien Régime. ${ }^{122}$ Those French-Canadian soldiers who joined the British army are equally praised for "defend[ing] Canada against the armies of the English Colonies now in rebellion against the King” (Kirby 747) during the Revolutionary War. Indeed, "the officers and leaders of the Canadians ... now donned

\footnotetext{
${ }^{122}$ Sorcerers on the island ... English soldiers in their peculiar uniform.
} 
the English uniform, and led their countrymen in the defence of Quebec, with the same valour and with better success, than when opposing Wolfe and Murray" (Kirby 749). Now that the threatening internal others - especially Caroline who could have saved New France from British conquest - have perished, the remainder of the population is able to assimilate willfully to the British Crown.

The final pages of The Golden Dog are dedicated to the legend of La Corriveau. After killing Caroline, La Corriveau develops a thirst to kill again. One year later, she cannot help herself and kills her husband, the Goodman Dodier, "by pouring melted lead into his ear while he slept!” (Kirby 753). Following her trial, execution, and gibbetting, "the hill of Levis where La Corriveau was gibbetted, was long remembered in the traditions of the Colony. It was regarded with superstitious awe by the Habitans [sic]. The ghost of La Corriveau long haunted, and in the belief of many, still haunts the scene of her execution" (Kirby 754). La Corriveau's death symbolizes the assimilation of French Canadians into the construction of a homogeneous and civil Canadian nation, an assimilation that is further facilitated by the fact that Caroline is also dead. While Caroline most evidently represents the Acadians and Abenaki through her mixed heritage, she is directly linked to New France's downfall: "Caroline de St Castin had she lived, might have averted the conquest of the Colony ... But it was not to be! No other influence for good remained after the death of the unfortunate Caroline" (Kirby 577). If Caroline's assassination is intrinsically linked to the downfall of New France, then the secret of her murder, symbolized by vicious stabbing, obscures the inherent violence of such defeat. Caroline's murder "pressed hard upon her [Angelique's] conscience and still harder upon her fears, [but] no man read in her face the minutest asterisk that pointed to 
the terrible secret buried in her bosom, and never discovered" (Kirby 750). Bigot, while suspecting Angelique of "complicity with the bloody deed," failed to find any proof (Kirby 750), and La Corriveau, the sole being who could have revealed this secret, sealed it in death.

Yet, the ending of Kirby's gothic romance is highly paradoxical and can be read in such a way that would make the work critical of English-Canadian romantic nationalism. In his study of the portrayals of Intendant Bigot in a handful of literary works including The Golden Dog, Maurice Lemire claims that "de tous les romanciers canadiens-anglais, il [Kirby] est le seul à pénétrer aussi profondément la mentalité candienne-française. Un point de notre psychologie a retenu son attention : notre complexe d'infériorité. Pas d'unité canadienne possible, selon lui, avant la guérison de ce traumatisme" ("La trahison de Bigot" 84-85). ${ }^{123}$ He posits that by incriminating Bigot and France, French Canadians could remove from themselves any blame regarding the loss of the colony and place it on the former, allowing themselves to renew their selfesteem, join forces with English Canada, and become a united nation (Lemire, "La trahison de Bigot" 85). In other words, Lemire suggests that in trying to advertise his goal of a pan-Canadian project, Kirby exploits the French Canadians' shortcomings and rewrites the pivotal moment in their history in hope of strengthening their bonds with the British. Quoting Lemire, Stacey clarifies that Kirby's “generosity and good will with respect to Canada's 'other' founding nation is perhaps rather more apparent than it is real" (101). It is clear to both Lemire and Stacey that Kirby's sympathetic portrayal of

\footnotetext{
${ }^{123}$ Of all English-Canadian novelists, Kirby is the only one to penetrate so profoundly the FrenchCanadian psyche. One aspect of our psyche captured his attention: our inferiority complex. No Canadian unity is possible, according to him, before our trauma is cured.
} 
French Canadians as victims of France and the Ancien Régime, and newly willing supporters of Britain, only serves the writer's own desire to see Canada united through its two "founding" people. In fact, the ending of The Golden Dog corroborates the finely nuanced distinction Stacey makes between the "apparent" and the "real," and reveals how Kirby actually does a disservice to French Canadians.

Since The Golden Dog fundamentally serves an English-Canadian romantic nationalist project, as shown through this analysis, it necessarily needs to obscure any violence relating to the creation of the nation-state and highlight the fabricated, harmonious image of national unity. At a first glance, it appears as though Kirby successfully obscures this violence through Caroline's and La Corriveau's respective silences and deaths. In reality, however, through the very act of writing and narrating the story, Kirby does not obscure the violence but rather reveals it to the readers. Furthermore, much like in Les anciens Canadiens, La Corriveau's lingering presence at the end of the novel memorializes such violence. These ambiguities between appearance and reality, as well as obscurity and revelation, are partially caused by the gothic function of La Corriveau as a revenant figure. To expand on an aforementioned quotation by Justin D. Edwards, "the trope of the phantom suggests what, on a political and social level, Slavoj Zizek refers to as the 'ideological apparatuses' of the return of the dead, a form of transgenerational haunting that is inherently political" (xxix). La Corriveau's perennial haunting at the end of The Golden Dog can therefore paradoxically be interpreted like that in Les anciens Canadiens wherein La Corriveau's ghostly presence serves as a form of transgenerational haunting that resists the amnesia and repression that accompanies the violent creation of nation-states. Rather than "sealing off a French 
national past from a Canadian national present" and providing "the possibility of a particular consolation, for its English reading public at least, in contemplating something that has not survived, and need not, therefore, be accommodated," Kirby demonstrates "the survival of a French cultural legacy into the present day" (Stacey 104-105). As "startling tales, raising the hair with terror, were told of her round the fire sides in winter" (Kirby 754), La Corriveau continues to haunt and upset the apparent image of a harmonious and unified Canadian nation-state.

Although Kirby shapes the Corriveau figure into a witch with a long ancestry of poisoners who plays a critical role in the murder of Caroline de St Castin and the consequent downfall of New France, he ultimately ties the figure back to de Gaspé's original rendition. After La Corriveau is adequately punished for murdering her husband, "all night long in the darkness she r[uns] after belated travellers, dragging her cage at her heels, and defying all the exorcisms of the church to lay her evil spirit" (Kirby 754). She strongly resembles de Gaspé's witch in her pursuit of travellers with her clicketing gibbet. Both de Gaspé's and Kirby’s Corriveau figures perform similar functions by supporting English-Canadian romantic nationalism in some ways, but the enactment of these functions differs quite substantially. Les anciens Canadiens paradoxically supports both French-Canadian and English-Canadian romantic nationalism. More specifically, in the spirit of an English-Canadian romantic nationalist project disguised as a FrenchCanadian one, de Gaspé vilifies British officers and subtly presents La Corriveau's desired allegiance with the British as a reflection of his own sociopolitical desires. In contrast, The Golden Dog paradoxically supports and inadvertently undermines EnglishCanadian romantic nationalism. Kirby's Corriveau figure actively participates in both the 
erasure of the threatening French-Canadian and Indigenous others, and the subsequent assimilation of those remaining into a British body politic, but ultimately remains a haunting figure in the history of Canada that betrays Kirby's impossible dream for a harmonious and united Canadian nation-state. 


\section{Chapter 3: WomaNation in Québécois Plays on La Corriveau}

There is a relative dearth of published material on the legend of La Corriveau between approximately 1885 and the 1940 s. ${ }^{124}$ According to Biron et al., a new literary period emerged in 1895 as Montreal replaced Québec City as the new literary centre (151). This new centre of activity established a geographical distance from the origins of the legend. Moreover, industrialization and urbanization affected the lifestyle of French Canadians, and they began enjoying, for instance, the burgeoning popular culture that encompassed non-literary activities, from theatre to film, music, and dance (Biron et al. 152). Within the literary sphere, writers had new political interests. No longer as concerned with the development of French-Canadian literature that was central to the nationalist literary movement of 1860 s, they focused on a new aesthetic and ideological debate until the 1930s: that between regionalists who promoted French-Canadian literature by employing "les thématiques propres [d'ici], des personnages du terroir et parfois même un langue spécifique, une 'langue à nous,"” and the exotiques (also called exotistes and parisianistes) who followed Parisian trends and adopted "un français raffiné et [faisaient] de la maîtrise de la langue un critère déterminant pour évaluer la qualité esthétique d'un texte" (Biron et al. 152). ${ }^{125}$ Literary works at the end of the nineteenth

\footnotetext{
${ }^{124}$ The year 1885 marks the publication date of the last prominent literary work focusing on the legend of La Corriveau in the nineteenth century, Fréchette's "Une relique," and excludes reprints and republications of existing literary works. Ferland and Corriveau survey works published between 1885 and the 1940s that were heavily inspired by the first texts featuring La Corriveau as follows: "Une nuit chez les sorciers" in Édouard-Zotique Massicotte's Conteurs canadiens-français du XIX $X^{e}$ siècle (1902), a republication of de Gaspé's work; Armand Leclaire's "Les sorciers de l'île d'Orléans ou la Corriveau" (1917), an almost word-for-word copy of de Gaspé's work; and Roméo Langlois's "Une Barbe-bleue canadienne : la Corriveau" (1939), which was heavily inspired by de Gaspé (236-40).

${ }^{125}$ The particular themes [of the region], the characters of the land, and sometimes a specific language, a 'language that belongs to us' ... a refined French and [made] linguistic mastery a determining factor in the evaluation of the aesthetic quality of a text.
} 
century and beginning of the twentieth gradually revealed how "l'ailleurs se rapproche et l'idéal du retour à la terre ... se heurte à la réalité du monde moderne. Les plus célèbres romans de la terre apparaissent alors, mais c'est pour évoquer un univers en voie de disparition" (Biron et al. 152). ${ }^{126}$ Even as a new generation of writers during the interwar period sought to move past the debate rather than fuel it further, the prominence of the ailleurs (elsewhere) in the literary divide between ici et ailleurs became unavoidable due to the overwhelming consequences of historical moments such as the Great Depression and the rise of fascism in the 1930s. The start of World War II led writers, artists, and intellectuals sojourning in France to return to Québec, creating a literary renaissance characterized by a fusion of French and French-Canadian (arguably American and English-Canadian, too) influences - a mixing of genres, themes, and ideas. Overall, the literary works produced in the extended period of 1895-1945 (for example, those of Émile Nelligan and Germaine Guèvremont) significantly differ from those on the legend of La Corriveau written in the previous decades. ${ }^{127}$

The legend of La Corriveau only reappeared in the mid-twentieth century after the publication of Lacourcière's research. An individual named Joseph-Eugène Corriveau initiated archival research in the 1940s with the aim of rectifying disparaging opinions on Marie-Josephte Corriveau. He died a few months after finding the necessary documents (December 3, 1947) and Lacourcière took on this project. Lacourcière sought to provide

\footnotetext{
${ }^{126}$ The 'elsewhere' approaches and the ideal of returning to the earth ... collides with the reality of the modern world. The most popular romans de la terre thus appear, if only to evoke a universe on the brink of extinction.

${ }^{127}$ Renowned folklorist Marius Barbeau from Sainte-Marie de Beauce, QC, began his life-long contributions to folkloric studies in 1913, publishing numerous collections of folk songs in the periodization Biron et al. describe. Barbeau did not write and interpret folkloric tales from French Canada in ways similar to de Gaspé, Le Moine, or Fréchette. Instead, he travelled in certain regions of the province to record the lyrics and sheet music of French-Canadian folk songs.
} 
accurate, historical facts about Marie-Josephte Corriveau's life, and explored the impacts of oral tradition on the development of the legend. Subsequently, new anglophone and francophone literary works recuperating the legend of La Corriveau emerged in the 1960s and more appeared in the following decades. From Vigneault's song "La Corriveau" (1966; recorded by Pauline Julien in 1972) to Beaulieu's and Hébert's plays (respectively, Ma Corriveau in 1973 and La cage in 1990), to the novels La Corriveau (1981) by Andrée Lebel and La fiancée du vent (2003) by Monique Pariseau, La Corriveau became a fixture in Québécois literature. These new texts drew on two main sources of material: the first, the malicious depictions of La Corriveau as established in nineteenth-century texts, especially de Gaspé's witch and Kirby's poisoner, and the second, Lacourcière's scholarship.

In combining these two sources—one based on fiction, the other on careful historical research — many of these writers engaged in what Herb Wylie calls "th[e] postmodern turn in historiography" (184), a turn that invites writers to engage once more with history and folklore. Although it would not be entirely accurate to categorize all of these contemporary texts about La Corriveau as works of historiographic metafiction, they do present certain overlapping aspects of Canadian and Québécois literary postmodernism. Drawing on Linda Hutcheon's theories of postmodernism, Wylie identifies "frame narratives, multiple narrators, unstable points of view, narrative selfreference, parody, [and] the recontextualization of documents" as recurring postmodern techniques (184). Janet M. Paterson similarly enumerates frame narratives, self-reference, and parody as some of the techniques characteristic of the Québécois postmodern. Many of these elements recur in the new adaptations of La Corriveau as twentieth-century 
writers were interested in exploring the postmodern potentials of the legend.

Postmodernism exposes the notion of an eternal and universal Truth as a construct, countering that there are many truths; postmodern art thus performs a shift in prime cultural value from universality to difference. Revealing the need to be aware that all systems of understanding are human constructs, postmodernism "questions the very bases of any certainty (history, subjectivity, reference) and of any standards of judgement" (Hutcheon, A Poetics of Postmodernism 57). In other words, it challenges any notion of a fixed centre of truth (Hutcheon, The Canadian Postmodern 3) and demands a re-examination of the centre that previously served as a point of reference upon which individuals could rely in interpreting the world around them. ${ }^{128}$ The works on the legend of La Corriveau in the second major wave of literary production firmly inhabit such an interrogative stance by questioning the meaning of the figure, which no longer seemed unequivocally evil. Such a re-evaluation inhered in the way these new Québécois literary works embraced the larger postmodern trend that brought forth the counternarratives of marginalized peoples whom Hutcheon calls "ex-centrics," those individuals who were "off-centre" because they did not ascribe to the dominant scripts of English Canadian, white, heterosexual, male normativity. Emerging out of the Quiet Revolution, Québécois literature encompassed a multitude of "ex-centric" narratives that did not

\footnotetext{
${ }^{128}$ Scholars such as Hutcheon and Christopher Norris have indicated a tension in the poetics of postmodernism and question its effective use in the representation ex-centric counternarratives. While postmodernism seeks to reject the notion of an absolute and totalizing Truth, this concept is complicated if there is a desire to erect a new Truth. Furthermore, if Truth and centre are constantly being interrogated and deconstructed, then as much as dominant groups are being decentred from their privileged position, excentrics and marginalized peoples cannot be represented in meaningful ways because there is no coherent basis to begin with and no basis on which to ground these new representations. See Hutcheon's A Poetics of Postmodernism (1988) and Norris's What's Wrong with Postmodernism: Critical Theory and the Ends of Philosophy (1990).
} 
conform to, and unmistakably challenged, the Canadian master narrative that enforced white, European (even more specifically British) models of civility, citizenship, and nationhood (Bannerji 112; Coleman 5; Mackey 24). Whereas nineteenth-century writers instrumentalized narratives featuring the legend of La Corriveau in an attempt to establish such a master narrative by supporting French- or English-Canadian romantic nationalist projects, the francophone literary productions relating to the legend from the 1960 s to the end of the twentieth century are Québécois nationalist revisions that constitute ex-centric counternarratives defining Québec against the Canadian metanarrative of homogeneity and unity.

Occurring at such a pivotal moment in history, La Corriveau's narrative foregrounds various borders including those existing between the Old World and the New World, British and French Canadian, English and French, as well as conqueror and conquered. The concept of borders is central to Canadian postmodernism as it symbolizes a demarcation between Canada's histories, languages, and cultures, as well as between Canada's literatures, dividing long-established national metanarratives from rising, excentric counternarratives. Hutcheon asserts that the re-examination of margins and borders precipitates a move away from the notion of centrality. It is unconcerned with the idea of origin, oneness (which she draws from Edward Said and John Rajchman), and monumentality (Friedrich Nietzsche) that foreground the nature of centrality as eternal and universal (A Poetics of Postmodernism 58). This interest in decentring and reclaiming the margins captures the Canadian obsession with borders, a possible product of Canada's perceived marginalized position on an international scale (Hutcheon, The Canadian Postmodern 3). Blodgett similarly notes the significance and value of borders 
in Canadian literature. In his article "Is a History of the Literatures of Canada Possible?," Blodgett details how Jacques Cartier, in erecting the "first Canadian frontier" (10), led us to become conscious of issues regarding the frontier dividing the colonizers from Canada's Indigenous population. More importantly, Blodgett believes that a "border in the Canadian sense is the zone of negotiation" and "a site of discursive contestation" ("Is a History of the Literatures of Canada Possible?" 5). Consequently, there are moments when it is possible to cross these borders and enter a productive space of negotiation. Congruent with Blodgett's claims, Robert Kroetsch asserts, "this very decentring [is what] gave a new energy to countries like Canada. Canada is supremely a country of margins" (62). Exemplifying how, "in some perverse way, this very falling-apart of our [Canadian] story is what holds our story together" (Kroetsch 61), postmodern cultural theory seeks not to create new national metanarratives, but rather to deconstruct them through the rejection of binary constructions.

Hutcheon is the leading scholar on postmodernism in English Canada, but many of the characteristics she describes about centre and margin can be applied to the new iterations of the legend of La Corriveau because they intersect with those of Québécois postmodernism as described by Paterson. Informed by Jean-François Lyotard's theories of postmodernism, Québécois postmodernism also seeks to deconstruct the centre and notions of capital "T" Truth. Lyotard asserts that, "en simplifiant à l'extrême, on tient pour 'postmoderne' l'incrédulité à l'égard des métarécits" (7). ${ }^{129}$ Lyotard's concept of heterogeneity, which similarly informs Hutcheon's own theorization of English-Canadian

\footnotetext{
129 "Simplifying to the extreme, I define postmodern as incredulity toward metanarratives" (xxiv, translated by Geoff Bennington and Brian Massumi).
} 
postmodernism, interrogates and opposes centrality, homogeneity, and unity (Paterson, "Le postmodernisme québécois" 79). Paterson attributes to Guy Scarpetta the "mélange des genres" (what Scarpetta calls l'impureté des formes) and cosmopolitanism that inform Québécois postmodernism (“Le postmodernisme québécois” 79). ${ }^{130}$ While Paterson argues that "le discours postmoderne québécois est ainsi marqué par un lien étroit avec la pensée française, à la différence des postmodernismes américains et canadien-anglais, fortement influencés par les écrits de Jameson, Hassan et Hutcheon" ("Le postmodernisme québécois" 79), my analyses on the transformations of the legend of La Corriveau during the postmodern era draw on the similarities of English-Canadian and Québécois postmodernisms, namely the rejection of the centre in favour of an examination of borders. ${ }^{131}$

In contrast to nineteenth-century texts that present the figure of La Corriveau as the evil French Canadian who succumbs to the powers of the British conqueror, mid- and late-twentieth-century Québécois writers depicted La Corriveau surmounting linguistic and cultural borders. The crossing of such borders produced new configurations of power that subverted the dynamics at play in previous adaptations of the legend of La Corriveau. As the Quiet Revolution gave rise to a new national and feminist consciousness, La Corriveau became emblematic of Québec's oppressed condition, even as she challenged English-Canadian culture. The present chapter continues Chapter

\footnotetext{
${ }^{130}$ The mixing of genres. With respect to cosmopolitanism, Scarpetta writes, "on définira volontiers 'l'écriture' comme une traversée des frontières, comme migration et exil" [We will gladly define 'writing' as a crossing of frontiers, like migration and exile. In terms of cosmopolitanism] (Éloge du cosmopolitisme 183). See Scarpetta's L'impureté (1985) and Éloge du cosmopolitisme (1981).

${ }^{131}$ The Québécois postmodern discourse is thus intrinsically linked to French thought, in contrast to American and English-Canadian postmodernisms, which were strongly influenced by the works of Jameson, Hassan, and Hutcheon.
} 
Two's project of examining the legend of La Corriveau from the perspective of alterity and otherness, but focuses on the other's transformation and "translation" in the politically charged era inaugurated by the Quiet Revolution. In this new context, the legend of La Corriveau is disarticulated from indigeneity and gains new Québécois nationalist and feminist dimensions.

The notion of translation is extremely helpful for describing the transformation of borders from walls into what Blodgett calls "zones of negotiation" and "sites of discursive contestation" in a multilingual and multicultural national context because it foregrounds a mediation between cultures, languages, and histories. Similar to Blodgett's stance concerning the "necessity of translation" when contemplating the possibility of transcending linguistic and cultural binaries ("Is a History of the Literatures of Canada Possible?" 10), Sherry Simon also asserts that "la traduction est devenue une activité de négociation entre des entités linguistiques et textuelles bien délimitées, soutenues par une série de frontières" (180). ${ }^{132}$ The use of the term "translation" here does not refer narrowly to the translation of one language to another, but to a cultural exchange at the heart of the negotiations and contestations between the two parties separated by a border. Ovidi Carbonell Cortés and Sue-Ann Harding note that such a conceptual expansion of the term has occurred within the field of translation studies. As I noted in the introduction, they contend that "far from being simply a matter of contrastive linguistics, translation is now regarded as a complex interlinguistic and intercultural process where the context of communication is of foremost importance" (Cortés and Harding 1).

\footnotetext{
132 Translation has become an activity of negotiation between linguistic and textual entities that are clearly delineated, maintained by a series of frontiers.
} 
Translation has, in other words, become a means of communication that transcends linguistic borders and can act as "a tool for the powerful and the disempowered, the majority status quo and minority voices" (Cortés and Harding 1). Such a reimagining of translation animates Québécois writers' empowering of the figure of La Corriveau to subvert the defamatory narratives that have tainted the legend for over a century.

Various scholars have already noted that works from this second wave of literary production featuring La Corriveau have "translated" the figure from a vilified witch or poisoner into a symbol for Québécois nationalism and feminism. In their respective analyses of the legend of La Corriveau in Hébert's La cage, both Kathryn Slott and Jessica McBride demonstrate how La cage significantly rewrites the legend of La Corriveau as a feminist narrative. ${ }^{133}$ Yet the feminist politics of La cage are often contrasted with the more overtly nationalist politics of Beaulieu's Ma Corriveau. Slott, for instance, comments that Beaulieu's version of the figure is "beaucoup plus nettement nationaliste que la version hébertienne" (155). ${ }^{134}$ In concert with this comment, McBride argues that La cage offers a more explicit commentary on feminism than on the colonized status of Québec. However, I argue that Beaulieu's Ma Corriveau (1973) and Hébert's La cage (1990) are both substantially concerned with the politics of nationalism and feminism. As Jill Vickers affirms, “colonial rule required control of women, who could reproduce indigenous languages, faiths, and identities; controlling women was key to

\footnotetext{
${ }^{133}$ Whereas Slott outlines the differences between Hébert's version of the legend with previous iterations of the legend, highlighting the feminist elements of the former, Jessica McBride posits that Hébert's version of the legend preserves fundamental elements of the historical narrative, but instrumentalizes them to rewrite the myth of La Corriveau. Specifically, McBride demonstrates how Hébert uses the eponymous cage - which, according to Lacourcière, is the most stable element of the legend of La Corriveau - in order to "dispel and denounce the nineteenth-century myth" (McBride 132).

${ }^{134}$ Clearly more nationalist than that of Hébert.
} 
disrupting or preserving national identities and the solidarities on which both

modernization and resistance to colonialism were based" (40). Smart likewise argues that when "reading Québécois literary texts with a consciousness of gender difference, one becomes aware ... of new dimensions in the thematics of nation or country" (Writing in the Father's House $\mathrm{x}$ ). One manifestation of this relationship between nationalism and feminism is the woman-as-nation trope wherein land and nation are conceptualized as a feminized body, a trope foregrounded in Beaulieu's and Hébert's plays. ${ }^{135}$

After a brief overview of the figure of La Corriveau's disarticulation from indigeneity, I demonstrate how Beaulieu and Hébert both employ postmodern techniques of "doubling" in their exploration of nation and gender, but arrive at radically different results. Beaulieu splits the figure of La Corriveau into two figures: the rebellious, defiant woman called La Corriveau Noire, and the innocent, naïve Corriveau Blanche. Drawing on various female archetypes, such as the mother figure, the widow, the frigid woman, and the wanton, Beaulieu dramatizes the inner tensions within Québec between resistance to, and advocacy for, national liberation. Despite Beaulieu's attempts to transvalue the woman-as-nation trope with feminism, he paradoxically continues to relegate Québécois women to the position of objects. Their absence as active subjects in Québec's liberation movement is symbolically manifested in the nation's failure to emancipate at the end of Ma Corriveau. Unlike Beaulieu, Hébert does not split the Corriveau figure in two, but

\footnotetext{
${ }^{135}$ Without necessarily terming it "woman-as-nation," numerous scholars have examined the intersection between gender and nation. See Joanne R. Sharp's "Gendering Nationhood: A Feminist Engagement with National Identity" (1996); Nira Yuval-Davis's Gender \& Nation (1997); Between Woman and Nation: Nationalisms, Transnational Feminisms, and the State (1999) edited by Caren Kaplan et al.; and Gendering the Nation-State: Canadian and Comparative Perspectives (2008) edited by Yasmeen Abu-Laban. Anne McClintock's Imperial Leather: Race, Gender, and Sexuality in the Colonial Contest (1995) similarly examines the intersection between race, gender, and class in imperial discourses.
} 
establishes clear parallels between two female characters in her play, Ludivine Corriveau and Rosalinde Crebessa, from the moment they are born. She uses the same representation of the woman-as-nation trope, namely through the mother figure, but significantly rewrites this tradition to transcend the borders between woman and nation, as well as object and subject. The nationalist angle is perhaps not as easily discernible in La cage because Hébert does not explicitly or exclusively use women as symbol-objects. Instead, she "translates" our understanding of gender and nation through her simultaneous rewriting of the mother figure and the Corriveau figure, as well as her transformation of nationhood's bonds of filiation to bonds of affiliation.

\subsection{From Indigenous to Québécois: La Corriveau's New Nationalist Association}

As we have seen, La Corriveau was typically presented as a gothic figure of otherness in the nineteenth-century literary works promoting English-Canadian romantic nationalism, but the character's function as a "figure of otherness" needs to be reconsidered after the 1960s, especially after the beginning of the Quiet Revolution in Québec and Canada's centennial celebrations. Paterson explains that "les mouvements socio-politiques de décolonisation et d'affirmation de la différence des années 1950 et 1960 ont eu un impact déterminant sur la prise en compte de l'altérité dans de nombreuses disciplines" (Figures de l'Autre 18). ${ }^{136}$ These movements allowed for alterity, at least on an epistemological level, to "s'inscri[re] au sein de la postmodernité" (Paterson, Figures de l'Autre 19). ${ }^{137}$ Furthermore,

\footnotetext{
${ }^{136}$ The sociopolitical movements of decolonization and affirmation of difference in the 1950s and 1960s had a definitive impact on the inclusion of alterity in numerous disciplines.

${ }^{137}$ Inscribe itself at the heart of postmodernity.
} 
depuis les années 1970, la pensée féministe a remis en question la notion de l'altérité de la femme, remise en question qui touche aux fondements de la construction ontologique et sociale de l'Autre. Dans ce nouveau contexte socioculturel et épistémologique, ce n'est pas uniquement la notion de l'Autre qui est en jeu, mais également celle du moi et de son identité. (Paterson, Figures de l'Autre 19-20) ${ }^{138}$

Central to the development of a new Corriveau figure was the disarticulation of $\mathrm{La}$ Corriveau from its earlier association with indigeneity. This disarticulation was facilitated by the changing nature of Indigenous cultural politics in Canada at the time; during the 1960s and 1970s, English Canada witnessed an increase in Indigenous activism and an efflorescence of Indigenous writing (McKenzie 33; Moss and Sugars, "Introduction: Nationalists" 218). This period of Native Renaissance "made a notable impact because it seemed to emerge out of a preceding 'period of silence' [that] ... coincided with Canada's residential schools, institutions which destroyed cultural pride, cultural worth, First languages, and much more" (McKenzie 34). In addition to this efflorescence of Indigenous writing, there was also an explosion in multicultural and minority writing in Canada from the 1970s onward that many commentators saw as having the potential to change Canada's previously established bicultural composition (Coleman 4). Mackey explains that this turn toward multiculturalism and indigeneity served as a justification for English Canada's anti-separatist sentiments concerning Québec. Following the results

\footnotetext{
${ }^{138}$ Since the 1970s, feminist thinking has brought about a reconsideration of the notion of female alterity, a reconsideration that addresses the foundations of the ontological and social construction of the Other. In this new sociopolitical and epistemological context, it is not solely the notion of the Other that is at stake, but also that of the self and identity.
} 
of the 1995 Québec referendum and the speech wherein the Premier of Québec, Jacques Parizeau, stated that the "yes" side lost due to the "money and the ethnic vote" (Mackey 27), The Globe and Mail quickly responded in an editorial piece, defining the "Canadian idea" in opposition to the racism Parizeau expressed. This piece contrasted French and English Canadians, portraying the former as racist and intolerant (Mackey 28). English Canadians also considered themselves less racist than the Québécois population in light of their self-perceived tolerance for Indigenous peoples. In English-Canadian attempts to establish an identity in opposition to French Canada, "multicultural and Aboriginal 'others' become necessary weapons in the war between the two 'founding' nations" as English and French Canadians manipulated images of their relationships with the Indigenous population to shape desired representations of nationhood (Mackey 28).

Meanwhile in Québec, the province's new political and economic relations with Indigenous peoples translated into the deliberate omission of Indigenous writers in official canons of Québécois literature. Indeed, in Québec,

on s'accorde généralement pour situer au début des années 1960 le point de départ de la construction de la politique étatique québécoise à l'égard des peoples autochtones. La compétence exclusive exercée en ce domaine par le gouvernement fédéral en vertu des dispositions de l'Acte de l'Amérique du Nord britannique explique en grande partie l'absence du gouvernement québécois dans ce dossier jusque-là. (Salée 119) ${ }^{139}$

\footnotetext{
139 "The elaboration of Quebec's policy on Indigenous Peoples began in the early 1960. Up to that point, the exclusive jurisdiction of the federal government in Indigenous affairs, in accordance with the provisions of the British North America Act, largely accounts for the Quebec government's absence on this policy front" (99, translated by Manon Tremblay).
} 
Daniel Salée notes that these interactions commenced as a result of the Québec government's desire to exploit James Bay for its hydroelectric potential (119). With respect to Québec, Indigenous literary works only began to emerge in the 1970s and 1980s. Diane Boudreau asserts that "les écrivains amérindiens, qu'ils écrivent ou non dans leur langage, qu'ils vivent ou non dans une réserve, n'ont qu'un seul objectif : prouver la valeur de leur culture et dénoncer la dépossession" (140). ${ }^{140}$ Indigenous literature in Québec was considered distinct from Franco- and Anglo-Québécois literatures. Rosemary Chapman claims that one reason Québécois literature excluded Indigenous writing from its literary canon was because of "the risk of apparent cultural assimilation" (183). The Native Renaissance, combined with Québec's desire to avoid any "risk of apparent cultural assimilation," may explain the absence of Indigenous representation in the new texts concerning La Corriveau. Then again, the absence of Indigenous writings in the Québécois literary canon may simply—and problematically— be an offshoot of Québec's desire to maintain its claims to nation-statehood while denying it to Indigenous peoples, whose claims to ongoing colonization and dispossession directly compete with the province's own nationalist discourse (Burelle 810). In any case, the changing nature of Indigenous cultural politics in Canada and Québec during this period led to the shedding of La Corriveau's earlier association with Indigenous culture (discussed in Chapter Two), and her subsequent transformation into a strictly nationalist symbol for Québec.

Concurrent with the rise of Québec's national consciousness, La Corriveau was

\footnotetext{
${ }^{140}$ Indigenous writers, whether or not they write in their language, whether or not they live on a reserve, only have one objective: to prove the value of their culture and to denounce their dispossession.
} 
reinvented in Québécois works as a symbol of colonial resistance and feminism from the late 1960s onward. ${ }^{141}$ The figure defied the disparaging cultural representation of Québec as a wife figure in regard to Canada, a depiction that was popularized in the sixties and persists to this day. As I explained in the introduction, Probyn asserts that cultural representations define Québec "as marginal to the majority, as peripheral to the center, as female to the male" in Canadian and North American contexts (72). More precisely, "the gendering of Québec and Canada as a couple in the throes of divorce is by now so common that it needs little explanation. It comes as no surprise that once again Québec is posed as marginal to and different from Canada and that this difference is then embodied in the wife" (Probyn 81). Aquin details the various portrayals of the marital relationship between Québec and Canada in the 1960s. For example, Canada and Québec are sometimes seen as entering a "forced marriage" wherein the Canadian husband proposes to Québec due to the economic advantages the situation presents, and the Québécois wife must accept because she does not have economic sovereignty (Aquin, Blocs erratiques 121). The feminization of Québec in cultural representations implies that the province is weak and inferior with respect to Canada; up until the nineties, Western ideologies equated femininity with “frivolousness, weakness, and subservience” (Pigeon 37).

The new Corriveau figure challenges such sexist depictions of bicultural marriage. Post-1960s Québécois texts, while presenting La Corriveau as a Québécois wife, depict her neither as weak nor subservient. Rather, her fortitude and disobedience

\footnotetext{
${ }^{141}$ This rise of national consciousness began with the Quiet Revolution, and persisted throughout the following decades with sociopolitical events such as the foundation of the Front de libération du Québec (FLQ, 1963) and the Parti Québécois (1968), the October Crisis of 1970, and the Québec Referendum of 1980 , to name a few critical moments.
} 
allow her to become a feminist symbol of national resistance. She is no longer interpreted as a victim of the British military regime, but as a figure that challenges British power and authority. Writers in the late-twentieth century portray her not as an actual witch or poisoner, but as a woman who is wrongfully accused of murder and labelled a witch by her peers because she deviates from social norms. In describing the modernization of La Corriveau following Lacourcière's scholarship, Alex Gagnon asserts that "les discours nationalistes et féministes redécouvrent la femme canadienne-française derrière le masque désuet de la sorcière diabolique. Désormais, 'la Corriveau' brandit un drapeau ou lève le poing. Elle devient la victime emblématique de l'oppression britannique d'un côté et de la domination patriarcale de l'autre" (16). ${ }^{142}$ The function of the legend among francophones therefore evolved from enriching French-Canadian culture in the nineteenth century to symbolizing Québec's fervent sociopolitical desires and ideologies of nationalism and feminism in the second half of the twentieth century.

\subsection{From Villain to Vixen: Challenging Québec's Feminized, Colonial Condition in Ma Corriveau}

Born on September 2, 1945, in Saint-Jean-de-Dieu, QC, Beaulieu is known as a journalist, writer, polemicist, and editor. He started his career in journalism as a chronicler for the Montreal weekly magazine Perspectives in 1966 and shortly after, began writing for other newspapers such as La Presse and began writing novels. He later worked as a professor of literature, as a screenwriter for popular téléromans in Québec

\footnotetext{
${ }^{142}$ Nationalist and feminist discourses rediscover the French-Canadian woman behind the outdated mask of the diabolical witch. Henceforth, La Corriveau waves a flag or raises a fist. She becomes the emblematic victim of British oppression on the one hand, and of patriarchal domination on the other.
} 
such as Race de monde (1978-1981), L'héritage (1987-1990), and Montréal P.Q. (19931996), and founded the publishing houses Éditions de l'Aurore (1973), Éditors VLB (1976), and Éditions Trois-Pistoles (1995).

In 2008, CBC published an article entitled "Quebec author will burn books to block bilingualism.” The article describes Beaulieu as one of the greatest Québécois writers of the contemporary period and details his ultimatum to the Québécois people: either they "correct what he considers its [the province's] errant linguistic ways" in the next two months, or he will burn the entirety of his works in a symbolic act of defiance against the ever-increasing anglicization of Québec ("Quebec Author Will Burn Books to Block Bilingualism”). Over the decades, Beaulieu has been overtly vocal about his disdain for Québec's assimilation to anglophone culture and his desire for a sovereign nation characterized by its francophone culture. In a comprehensive study of Beaulieu's body of works over the last six decades, Pierre Laurendeau explains that his literary masterpieces are built "sur l'extrême pessimisme de Victor-Lévy Beaulieu dominé par la désespérance de soi-même et du people québécois, l'un et l'autre indissociablement liés par le même destin fragile, mêmement écartelés entre l'impuissance d'agir et le désir de liberté" (x). ${ }^{143}$ These themes are thoroughly explored and dramatized in Beaulieu's $M a$ Corriveau (1976), the first literary work on the legend that has the figure of La Corriveau embody Québécois nationalism.

In 1973, Beaulieu was working as a literature professor at l'École nationale de théâtre du Canada. His colleague, the well-known Québécois actress Michelle Rossignol,

\footnotetext{
143 On Victor-Lévy Beaulieu's extreme pessimism, dominated by despair of himself and the Québécois people, one and the other indissociably linked by the same fragile destiny, similarly torn between the inability to act and the desire for freedom.
} 
was a professor of acting at the same institution and requested Beaulieu to write a play that her graduating students would perform (Cadieux 115). The play was published by Beaulieu's publishing house, VLB Éditeur, in 1976, and it was performed professionally at the Centre du Théatre d'Aujourd'hui in Montreal for the first time that same year from September 16 to October $13 .{ }^{144}$ This performance, which was the most widely reviewed among all Ma Corriveau productions, spurred mixed reactions. Québécois poet and essayist Jean-Paul Daoust with over thirty poetry collections, among other works, claimed the appearance of the two Corriveau figures, the father, and La Justice was "la seule chose intéressante du spectacle. ... Le reste est grossier et tombe en ruines" (81). ${ }^{145}$ In his comments on the greenery décor meant to evoke the Île d'Orléans, he asserts that “on se croirait dans une discothèque fuckée. Tout le spectacle est d'une symbolique nulle. ... et maintenant une autre de nos femmes célèbres devenue gadget. Encore une fois, le Théâtre d'Aujourd'hui est un théâtre d'hier" (Daoust 82). ${ }^{146}$ In contrast, Québécois writer and journalist Jean O'Neil writes in an article in La Presse on September 17, 1976, that "la mise en scène de cette pièce ... est évidemment un tour de force qui vaut des grands coups de chapeau à toute l'équipe" (11). ${ }^{147}$ Even if "à des esprits contemporains, Beaulieu aurait de la misère à conter des peurs," the play still has "un charme certain et

\footnotetext{
${ }^{144}$ Staged by André Pagé, its cast included Diane Ricard (La Corriveau Blanche), Évelyn Regimbald (La Corriveau Noire), Ernest Guimond (Jos Violon), Gilbert Lepage (Tom Caribou), Jacques Rossi (Titange), Yves Labbé (Fefi Labranche), Guy Nadon (Zèbre Roberge), Denis Chouinard (Joseph Corriveau), François Berd (La Justice), and Pierre Lebeau (Le Coq Pommerleau). Others involved in the production were Pierre F. Brault (music), Jean Bélisle (décor), François Barbault (costumes), and ClaudeAndré Roy (lighting) (Daoust 81; "Ma Corriveau - Centre du Théâtre d'Aujourd'hui").

${ }^{145}$ The only interesting thing about the performance.... The rest is crude and falls to ruins.

${ }^{146}$ One would think we were in a fucked-up nightclub. The whole performance is of a lame symbolism. ... and now another one of our famous women has become a gadget. Once again, the Théatre d'Aujourd'hui [theatre of today] is a theatre of yesterday.

${ }^{147}$ The staging of the play .... is evidently a tour de force that merits great applause for the whole team.
} 
désuet qui parle du passé, des origines et qui tempère un peu le choc du futur qu'on éprouve à certains moments devant la télé-couleur" (O’Neil 11). ${ }^{148}$ Despite the negative reviews, an article appearing in Le Devoir on October 21, 1976, notes that the play is a "succès extraordinaire" and that the theatre has extended its performances to October 31 ("Ma Corriveau prolongée"). ${ }^{149}$ Since then, the play has been performed four other times, all in the 1970s. ${ }^{150}$ Emblematic of its time - the time of le nouveau théâtre québécoisMa Corriveau is a work about liberation and political affirmation. ${ }^{151}$

Rather than depicting the figure of La Corriveau as a symbol of various cultures including French-Canadian, Scottish, Acadian, and Indigenous, as seen in previous iterations of the legend, Beaulieu sets it up to represent a Québec that he dreams of seeing, and contrasts it with the existing state of Québec. He dramatizes the internal split within Québec using various female archetypes that incarnate the woman-as-nation trope. It is precisely “dans ce genre de tension, où se jouent, par l'entremise de l'Autre fictif, à la fois la différence et la ressemblance, l'écart et le rapprochement, que se situe l'enjeu

\footnotetext{
${ }^{148}$ Contemporary souls would think Beaulieu had difficulty recounting scary stories. ... a certain charm and antiquity that speaks of the past, of origins, and that subdues a bit the shock of the future which we sometimes experience in front of colour television.

${ }^{149}$ Extraordinary success.

${ }^{150}$ The first student performance staged by Michelle Rossignol at the École nationale and the professional performance staged by André Pagé at the Théatre d'Aujourd'hui were in 1976. The third performance was staged by Jacques Crête and performed by the student theatre troupe Théatre de l'Eskalier at the Centre culturel de Trois-Rivières on June 4, 1978 ("'Ma Corriveau' au Centre culturel" 24). The fourth performance was staged by Lorraine Pintal at L'Atrium in Montreal in September 1978 (Armstrong and Miljours 174) and January 1979 (Brousseau 13). The fifth and last performance was performed by the troupe Le Théâtre de l'Atrium at the Université du Québec à Trois-Rivières on October 27, 1978 ("Le Théâtre de l'Atrium joue 'Ma Corriveau"' 13).

151 "Typified by rebirth at the hands of Man," the nouveau théâtre québécois, at times simply considered the birth of Québécois theatre in general, encompasses plays spanning 1960 and 1976 that are "selfconsciously Québécois in form, theme, and language" (Hurley 60), reflecting and revealing the lived experience of typical Québécois society. Scholars often attribute the origins of this emerging Québécois theatre to Michel Tremblay's Les belles-soeurs (1965). See Michel Bélair's Le nouveau théâtre québécois (1973) and Erin Hurley's "National Reflection: Michel Tremblay's Les belles-soeurs and le nouveau théâtre québécois" (2011).
} 
véritable de l'altérité et la force dynamique et inépuisable de sa représentation dans la littérature" (Paterson, Figures de l'Autre 38). ${ }^{152}$ In this analysis, I draw on Paterson's theories of Québécois postmodernism and alterity to show how reading Beaulieu's $M a$ Corriveau through a postmodern lens generates new understandings of La Corriveau as a figure of otherness signifying the internal split within the Québécois nation. By using literary techniques characteristic of postmodern literature, Beaulieu deconstructs, and then reconstructs, La Corriveau as a split figure that simultaneously embodies a traditional Québec and a new Québec that wants to be liberated from its colonial condition but remains trapped. I argue that while Beaulieu seeks to align the woman-asnation trope with feminism by equating the sexual liberation of the female body to the national liberation of Québec, his approach ultimately perpetuates the trope of the female body as a signifier for the colonial conquest of territory. In this way, Ma Corriveau illustrates how the perpetual objectification of the Corriveau figures cements a dual impossibility: it is impossible to emancipate Québécois women and the Québécois nation simultaneously when the former is employed as a metaphor for the latter.

Scholars such as Hutcheon and Paterson argue that metafiction is a fundamental characteristic of postmodern literature. In the simplest terms, Hutcheon defines metafiction as "fiction about fiction - that is, fiction that includes within itself a commentary on its own narratives and/or linguistic identity" (Narcissistic Narrative 1). As expressed in the title of her monograph, Narcissistic Narrative: The Metafictional Paradox, metafictional texts are narcissistic in that they showcase a certain level of

\footnotetext{
${ }^{152}$ In this type of tension, through the fictive Other wherein difference and resemblance, divergence and convergence, are all played out, that is situated the key issue of alterity, and the dynamic and endless potency of its representation in literature.
} 
"textual-awareness" (Narcissistic Narrative 1). Paterson similarly notes the close relationship between metafiction (autoreprésentation) and postmodernism. She writes, “on ne saurait, en fait, sous-estimer l'importance de l'autoreprésentation dans le roman postmoderne: narcissique, autoréflexif, celui-ci exhibe toujours son propre fonctionnement" (Paterson, Moments postmodernes 25). ${ }^{153}$ Hutcheon and Paterson therefore have similar understandings of metafiction as narcissistic texts aware of their own condition as fiction. In analyzing postmodern Québécois novels, Paterson identifies three primary levels on which metafiction manifests itself: énonciation/narrateur, énoncé/narration, énonciation/narrataire. ${ }^{154}$ Beaulieu's play presents metafictional elements at all three levels, firstly drawing on the énonciation/narrator and énoncé/narration to create a dramatic setting that opposes and exposes "fixed system[s], order, and wholeness" in order to "make room for new models based on things once rejected: contingency, multiplicity, fragmentation, discontinuity" (Hutcheon, The Canadian Postmodern 19). The breakdown of fixed systems and internal dynamics of the legend of La Corriveau is a necessary step toward repurposing the legend for Québec's new nationalist project. The first level, énonciation/narrator, is perhaps the most immediately discernible. Typical of metafiction is the presence of a fictional writer. Oftentimes, the narrator assumes the role of the writer, and this function evokes the presence of the actual writer of the literary work. This form of mimicry draws attention to the literary work's artificiality as a product of fiction (Paterson, Moments postmodernes

\footnotetext{
153 "The importance of self-representation in the postmodern novel should not be underestimated. Narcissistic and self-reflexive, it always reveals its inner workings" (26, translated by David Homel and Charles Phillips).

${ }^{154}$ David Homel and Charles Phillips translate these terms as "énonciation/narrator," "énoncé/narration," and "énonciation/narratee" (27, italics in original).
} 
27). In wanting to recreate a traditional Québécois storytelling setting, Beaulieu chooses a storyteller to be his narrating protagonist (indeed, this character narrates the story of the play to the audience), rather than an auctorial figure. This storyteller is in a constant state of exchange with his implied audience. The audience belongs to the level of énonciation/narratee and plays an integral role in the metafictional spectacle. Just as the writer figure highlights the act of writing, the theatrical audience highlights the viewing of the performance. Paterson argues that "si on situe le lieu de l'interprétation au niveau de l'acte de la lecture, de nouvelles possibilités se présentent: les frontières divisant le texte (perçu comme un système clos) et l'activité de lecture sont abolies et dès lors l'identification, et même la superposition du lecteur au narrataire, devient non seulement possible mais souhaitable" (Moments postmodernes 33-34). ${ }^{155}$ In Ma Corriveau wherein the storyteller replaces the auctorial figure, the listener is equated to the audience member. Jos Violon addresses multiple narratees including the characters in the play who listen to his narration of the legend of La Corriveau, the audience watching the play being performed, as well as the readers of his literary work. The presence of these various narratees abolishes the borders dividing the text/oral story and the act of reading/listening, to use Paterson's words, by continuously breaking the fourth wall.

Through his character Jos Violon, Beaulieu demonstrates the impossibility of finding the "truth" behind Marie-Josephte Corriveau's narrative and the impossibility of constructing an authoritative version of the legend. Ma Corriveau begins with Jos Violon

\footnotetext{
155 "New possibilities appear if we place the site of interpretation in the reading act: both the boundaries separating the text (seen as a closed system) and the reading act are abolished. From then on, identifying and even superposing the reader onto the narratee become not only possible, but desirable" (34, translated by David Homel and Charles Phillips).
} 
addressing the members of the audience, telling them about his love for storytelling and desire to share with them the legend of La Corriveau. He snaps his fingers and makes the other characters—-Tom Caribou, Titange, Fefi Labranche, and Zèbre Roberge—appear and convinces them to participate in a re-enactment of La Corriveau's trial. ${ }^{156}$ Jos Violon is a character whose complexity enables him to function as a metafictional device in a fairly transparent manner. He is a historical character who lived in the nineteenth century and is featured in eight of Louis Fréchette's contes. Indeed, when Louis Fréchette (18391908) was a young boy, he would gather with the other villagers and listen to the stories and legends that were told by the elderly Jos Violon. In an attempt to preserve and share Jos Violon's masterful skills as a raconteur, Fréchette created a fictional Jos Violon, “un conteur d'expérience à qui il délègue la parole ... Fréchette ou le narrateur premier ne fait que reproduire la simulation conventionnelle du conte oral et de l'échange verbal entre un conteur et son public" (Boivin 192) ${ }^{157}$ As Aurélien Boivin argues, "la délégation de la narration est un procédé récurrent dans le conte littéraire (ou fixé à l'écrit) du XIX siècle" (192). ${ }^{158}$ Considering that La Corriveau initially emerged as an oral legend, Jos Violon's presence in Ma Corriveau simultaneously recalls the origins of the legend, reveals the dynamic nature of les contes et légendes, and helps Beaulieu build a richly intertextual play that looks inwardly, thus consolidating Québec's literary culture through references to various periods of Québécois literary history.

\footnotetext{
${ }^{156}$ Although the men participate in the re-enactment, the two Corriveau figures are usually played by two female actors who later appear on stage.

${ }^{157}$ An experienced raconteur that he makes his spokesperson ... Fréchette or the narrator simulates the conventions of the oral conte and the verbal exchange between a raconteur and his or her public.

${ }^{158}$ The delegation of the narration is a recurrent process in the literary conte (or fixed in writing) of the nineteenth century.
} 
Throughout the play, the audience is reminded of the process of creation inherent to history and fiction. As Hutcheon notes, "historiographic metafiction questions the nature and validity of the entire human process of writing - of both history and fiction" (The Canadian Postmodern 22). When the two Corriveau figures recount their story to Tom Caribou, who plays the judge during the re-enactment of Marie-Josette's trial, he replies, “ment'rie ! Ment'rie ! Ment'rie trois fois ! Toute ça, c'est du jabotage digne de Jos Violon, Marie-Josette Corriveau !” (Beaulieu 44). ${ }^{159}$ He attacks Marie-Josette's testimony on two accounts. First, he claims that Marie-Josette is lying. Second, he equates her testimony to Jos Violon's stories. The comparison between lies and storytelling brings to attention the process of narrative construction; it functions on the basis that storytelling has no authoritative value in that it is constantly changing. A story is adapted every time it is being told, and thus one must consider the fabricated nature of narratives surrounding Marie-Josephte Corriveau's court trials, as interpreted and recorded in the historical documents, as well as its later dissemination in oral and written cultures.

In his extensive study on Jos Violon as a character in Fréchette's works, Boivin argues that Jos serves as a raconteur, but he is also a moralist and a pedagogue as he imparts morals to his audience and provides them with life teachings every time he tells a tale. Part of his task as a moralist is to select a character who will quickly become "isolé

\footnotetext{
${ }^{159}$ Lies! Lies! Three times lies! All of this, it’s gibberish worthy of Jos Violon, Marie-Josette Corriveau! To the best of my abilities, my translations of the passages from Ma Corriveau will capture the meaning of the quotations. However, due to the difficult nature of the task, I cannot in my translations fully convey the colloquial, populous, and exaggerated tone of the language register Beaulieu uses. Furthermore, based on the historical figure Marie-Josephte Corriveau, the character in Beaulieu's play is called Marie-Josette Corriveau.
} 
du groupe auquel il appartient, pour mieux faire ressortir sa déviance" (Maurice Lemire qtd. in Boivin 195). ${ }^{160}$ After the other characters refuse the role of the English judge in Jos Violon's story, Tom has no choice but to become the authoritative English judge. As a symbolic cultural other, he is isolated from the group and can thus be reprimanded for his deviance, which in this case, relates to his desire to uphold a monolithic truth and oppose any counternarrative with which the characters provide him. In serving as the English judge in the re-enactment, Tom's words against Marie-Josette are his attempts to establish the "real" Truth. His accusation suggests that if Marie-Josette is lying, then his own narrative must be the truth. In Fréchette's stories, Jos Violon is always presented as the protagonist who uses "un contre-discours efficace ... qui lui mérite la sympathie de ses auditeurs," in contrast to the other character who "est automatiquement [désapprouvé]" (Boivin 197). ${ }^{161}$ This observation therefore suggests that Beaulieu's Jos Violon is not a liar, and that it is Tom who ought to receive no approbation or validation for his desire to uphold a monolithic truth. Jos Violon's presence in the play therefore disrupts any binaries previously attached to Fréchette's original Jos Violon figure and rejects what Hutcheon calls Truth with a capital "T."

Jos Violon's role in elucidating the literary work's self-reflexivity coalesces with the postmodern techniques typical at the second level of metafictional analysis, the énoncé/narration. According to Paterson, one of the ways metafiction is manifested in the diegesis is through the process of repetition. Beaulieu makes use of repetitive strategies such as frame narratives and character doubles. With respect to frame narratives, when

\footnotetext{
${ }^{160}$ Isolated from the group to which he belongs, to better elucidate his or her deviance.

${ }^{161}$ An effective counter-discourse ... that merits him the sympathy of his audience ... is automatically disapproved.
} 
Jos Violon first appears on stage, he creates the first narrative. When he summons his friends with a snap of his fingers, they all appear and begin chatting like old friends who have not seen each other in a while. This setting constitutes the second narrative nested within the original frame. When Jos Violon convinces them all to participate in a reenactment of La Corriveau's trial, they enter the third narrative - that is to say, a secondorder nesting that turns the "second" nested narrative into a frame narrative. The frame narrative, also known as a play within a play in dramaturgical terms, is a "processus de redoublement" and a "manifestation de l'autoreprésentation au niveau de l'énoncé" (Paterson, Moments postmodernes 28). ${ }^{162}$ Gerhard Fischer and Berhnard Greiner similarly claim that "the play within the play would seem to be a particularly apt device for the expression of the playful self-referentiality of the post-modern condition" and that it can function "as a 'romantic' site which encompasses all constituent elements of art (in the sense of borders being suspended or transcended)" (xiii). In using not one, but two frame narratives, Beaulieu expounds the inherent artificiality surrounding the construction of the legend. Through the presence of the storyteller Jos Violon and the play's structure consisting of a double-frame narrative, Beaulieu is able to break down any notion of a fixed narrative surrounding the legend of La Corriveau before reconstructing it into his desired image of a strong Québécois nation.

In seeking to break down fixed narratives surrounding the legend of La Corriveau, Beaulieu also breaks down metanarratives about Québec. There were two main portrayals

\footnotetext{
162 "Doubling process ... evidence of self-representation on the level of the énoncé" (28, translated by David Homel and Charles Phillips, italics in original).
} 
of women as national symbols in men's writing in 1960s Québec. As Katherine A.

Roberts explains,

a complex love/hate relationship with female figures who symbolize the emerging Quebecois nation - either celebrated as the incarnation of the woman/country "pays" in need of liberation and protection, or hated as the "bad Mother," figurative embodiment of retrograde rural and religious values - permeates much of 1960s men's writing from Pierre Maheu's essays in Parti pris to the Hexagone poets and beyond. This is a generation of authors profoundly troubled by the female presence, by a Castrating Mother or Widow who for them symbolizes Quebec's domination within Canadian confederation. (21)

One of the most inventive elements of Beaulieu's play is the fact that there are two Corriveau figures: one embodying the celebrated incarnation of the woman/country in need of liberation and protection, and the other the retrograde rural and religious values of Québec. La Corriveau Blanche, as the symbolism behind her name suggests, is a naïve and innocent character who denies murdering her husband and claims she simply wanted a good life, whereas La Corriveau Noire admits to relishing in her murderous acts, and divulges her sexual impulses and overall frustration due to her late husbands' inability to satisfy her sexually. At the beginning of the trial, La Corriveau Blanche and La Corriveau Noire often speak in unison, but they quickly separate into two distinct voices, with the latter interfering and casting doubt on the former's testimony.

La Corriveau Noire and La Corriveau Blanche differ from each other as "la femme diable, la démone, la jouissive, fa[it] contrepoids à la femme vierge, la mère et 
l'épouse" (Laurendeau 30). ${ }^{163}$ Indeed, this discrepancy does not have significant value until there is a sign of threat. Beaulieu plays with what Paterson calls différence and altérité. The latter notes that difference is a common phenomenon wherein "A" is different from "B." This difference necessarily implies that "B" is also different from "A." Différence becomes altérité once there is a "groupe de référence, habituellement le groupe dominant, [qui] fixe l'inventaire des traits différentiels qui serviront à construire les 'figures de l'Autre'; construction qui produit souvent des systèmes de ségrégation” (Paterson, Figures de l'Autre 25). ${ }^{164}$ Beaulieu capitalizes on the use of an othered figure whose marginal status and alterity allows it to be "libre des pressions uniformisantes d'une société ou d'un groupe" (Paterson, Figures de l'Autre 168). ${ }^{165}$ As we will see below, La Corriveau Blanche is part of the reference group as she embodies various types of female archetypes representing the preservation of the existing state of Québec. Regardless of her literary representation as the "traditional Québécois woman," the "Frigid Woman," or the "Widow" (representations that are sometimes contradictory), she symbolizes an acceptance of Québec's subordination to English Canada. La Corriveau Noire opposes her angelic counterpart, and therefore opposes the reference group. She symbolizes liberation-liberation from the uniformizing pressures of society, sexual liberation, and national liberation - through her revision of the woman-as-nation trope, her denunciation of feminized and colonized Québécois men, and, perhaps surprisingly, her subsequent embodiment of the virile Québécois man.

\footnotetext{
163 The she-devil, the demon, the pleasured, counterbalances the virgin woman, the mother, and the wife.

${ }^{164}$ Reference group, usually the dominant group, [that] establishes an inventory of differential traits that serve to construct the 'figures of Otherness'; a construct that often produces systems of segregation.

${ }^{165}$ Free of the uniformizing pressures of a society or a group.
} 
Submissive and subservient at the expense of her well-being and happiness, La Corriveau Blanche embodies the traditional Québécois woman. This type of woman, who also upholds values of purity and domesticity is often tied to a female figure deemed "traditional" or conservative because she preserves patriarchal structures rather than paves the way for feminist ideals. While such discussions certainly fall in the realm of gender studies, they can also be included in studies of nationhood. Stéphanie Lanthier argues that in Québec, during the first half of the twentieth century, women were attribu[ées] symboliquement les valeurs maîtresses de l'idéologie clériconationaliste, c'est-à-dire qu'elles sont gardiennes de la foi chrétienne, de la langue et des traditions. Ces rôles servent un discours qui vise à garder les femmes cantonnées dans la sphère privée et, du même coup, assurer qu'elles ne peuvent évoluer dans la sphère publique, la sphère politique. $(82)^{166}$

Consequently, they were continuously excluded from having an active role in Québec's quest for national liberation (Lanthier 82). More importantly, they were synonymous with "des traditions religieuses et du passé colonial," and were seen as "un mythe 'tout' puissant, par lequel est symbolisé la faiblesse culturelle du Québec” (Lanthier 112) because they symbolized the values of an old Québec that contrasted and prevented the actualization of a nationally liberated Québec. ${ }^{167}$ In other words, by embodying an

\footnotetext{
${ }^{166}$ Symbolically attributed the key values of clergical-nationalist ideology, that is to say that they are the guardians of Christian faith, language, and traditions. These roles contribute to a discourse that seeks to keep women confined to the private sphere and, at the same time, ensure that they cannot evolve in the public sphere, the political sphere.

${ }^{167}$ Religious traditions and a colonial past ... an 'all-powerful' myth by which is symbolized the cultural weakness of Québec. As an aside to the translation, although Lanthier specifically ascribes the mother figure in Québécois literature to this symbolism (since the mother is the transmitter of culture and tradition), based on her aforementioned examination of the role of women in Québécois society, I contend that this symbolism can extend to female figures that are not necessarily mothers, but who have learned these values from their mothers.
} 
ideological position set in opposition to national liberation, La Corriveau Blanche therefore endorses English Canada's domination over Québec.

With the initial compliance of La Corriveau Noire, La Corriveau Blanche narrates her early years of womanhood. She explains how she fell in love with her first husband, François. Both Corriveau figures agree that "dans l'amour, quand ça va ben, y a rien à dire dessus ça, ça sert à rien de s'chiffonner la comprenure, on prend ça comme ça vient, sans ch'niquer sus l'ouvrage. Pour lorsse, la nuitte est noire et pis c'qui s'fait dans l'noir doit rester dans l'noir!" (Beaulieu 43). ${ }^{168}$ However, as La Corriveau Blanche explains that she is innocent in the deaths of both her husbands, François and Ti-Oui, the judge begins accusing her and claims that her quick elopement with the latter, three months after François's death, is "louche, très très louche!" (Beaulieu 47). ${ }^{169}$ She becomes upset, affirming that 'icitte, dans c'te maudit pays d'chréquins vingueux, y a rien qu'du placotage pis du délationnage!" but also begrudgingly admits that her relationship with Ti-Oui was one that lacked passion and love since he spent all of his time with his horse (Beaulieu 48) ${ }^{170}$ La Corriveau Blanche chooses to preserve a state of peace rather than to confront Ti-Oui in order to have "une belle place dedans l'ciel" when she dies even though she is dissatisfied with her romantic and sexual relationship (Beaulieu 65). ${ }^{171}$

In addition to embodying the traditional Québécois woman, La Corriveau Blanche's lack of sexual experience equates her to the "Frigid Woman." Laurendeau

\footnotetext{
${ }^{168}$ In love, when everything goes well, there isn't anything to say about it, it's not worth rustling one's understanding, we take it as it comes, without complaining about the work. So when night is dark, what's done in the dark stays in the dark!

${ }^{169}$ Suspicious, very, very suspicious!

${ }^{170}$ Here, in this damned country of good for nothing Christians, there's only gossip and abandonment!

${ }^{171}$ A nice place in heaven.
} 
writes in his analysis of Ma Corriveau, "dans une société où régnait la mère au foyer, il n’y avait pas de place pour les plaisirs du corps de la femme. Si elle s'intéressait le moindrement au sexe, elle devenait vite une putain, une dévergondée ... Cette femme corporelle et terrestre devenait une espèce de sorcière" (31). ${ }^{172}$ The pure woman who represses all of her sexual impulses recalls Aquin's allegory of the frigid woman. In "Le corps mystique," Aquin equates a woman's achievement of sexual orgasm with Québec's achievement of national liberation. He argues that while a woman may have sexual impulses, achieving such orgasm may be difficult. Similarly, while Québec may have liberational impulses — with separatism and the FLQ acting as stimuli — it may be difficult to achieve national liberation. Québec's unresponsiveness and metaphoric frigidity to the separatist stimuli therefore equates it to the frigid woman. La Corriveau Blanche thus captures the essence of Aquin's frigid woman; although attracted to François and Ti-Oui, she never had the opportunity to be in a relationship that fulfilled all of her sexual needs.

La Corriveau Blanche also corresponds to a female figure that is deemed even worse than the mother or the frigid woman: the Widow. Pierre Maheu writes that “l’image fondamentale qui nous hante, plus profondément que celle de la Mère, c'est celle de la Veuve; notre idéologie se réduisait à un mot : survivance. De l'archétype de l'araignée dévoratrice aux 'mères', femmes vêtues de deuil, 'épouses du christ', en passant par nos mères martyres, notre imagination était hantée" (27). ${ }^{173}$ All of these

\footnotetext{
${ }^{172}$ In a society in which reigned the housewife, there wasn't room for the pleasures of the female body. If she was in the least interested in sex, she quickly became a whore, a wanton ... This bodily and earthly woman became some sort of witch.

173 The fundamental image that haunts us, more profoundly than the Mother, is the Widow; our ideology was reduced to one word: survivance. From the archetype of the devouring spider to 'mothers,' women dressed in mourning, 'wives of Christ,' as well as our martyr mothers, our imagination was haunted.
} 
figures (the mother, the frigid woman, and the widow) are in some ways pure or nonsexual beings. However, whereas the traditional Québécois woman, who is often ascribed a motherly role, can disseminate her culture and tradition to future generations in order to consolidate Québec's retrograde, colonial condition, the Widow's failure to reproduce (at least, while husbandless), and thus re-produce the old nation, seems rather contradictory since it would eventually lead to Québec's extinction rather than its survivance. Despite these contradictory images, Beaulieu continuously situates La Corriveau Blanche in a position that stands against Québec's national liberation.

If La Corriveau Blanche, as the woman who forgoes "les plaisirs du corps de la femme," is relegated to the role of the frigid woman or the unproductive widow, then La Corriveau Noire does not simply express difference, but reclaims the position of otherness through her rejection of the values of the traditional Québécois woman and the value hierarchy that ascribes a negative connotation to her wantonness. Once the innocent Corriveau Blanche confesses her secret feelings about her sexual relationships with her late husbands, La Corriveau Noire interrupts and reveals a distinct and overt personality. She revises the woman-as-nation trope, a concept that has been "employé pour penser précisément la passivité féminine (objet national) par rapport à l'activité masculine (sujet national) ainsi que le caractère hétérosexiste du nationalisme dans la construction des liens entre corps féminins et territoire national” (Ravary-Pilon 57). ${ }^{174}$ As V. Spike Peterson asserts, "la Femme-nation exprime une féminité spatiale et incarnée : la fécondité de la terre, dont dépendent les gens, doit être protégée contre l'invasion et la

\footnotetext{
${ }^{174}$ Employed to think precisely about feminine passivity (national object) with respect to masculine activity (national subject) as well as the heterosexist character of nationalism in the construction of the ties between female bodies and national territories.
} 
violation, donc en défendant les limites du corps/nation" (Peterson qtd. in Ravary-Pilon 58). ${ }^{175}$ La Corriveau Noire conforms to this trope as her continuous desire for sexual liberation connects her body to the nation's territory and thus the desire to liberate it from its colonial condition. Yet, she is not protected from "l'invasion et la violation." La Corriveau Noire was protected by neither her father nor her husbands. She maintains, “j’sommes pas une p’tite fille ... j’sommes capabe de m'défendre tu seule... Ça fait des années que j'me défendons tu seule" (Beaulieu 54). ${ }^{176}$ The fact that she does not require male protection for her body/nation subverts the woman-as-nation trope. Her self-reliance and self-protection results from her father's cowardice and inability to protect New France, as well as her husbands' infertility and devirilization, all factors that contributed to the men's failure to protect the woman-as-nation, that is to say, La Corriveau Noire.

La Corriveau Noire denounces the men's cowardice and stupidity: "vous faites piquié!... Vous l'premier, M’Sieur l'Juge, vous faites piquié!” (Beaulieu 54). ${ }^{177}$ She pities the judge for believing that her father could possibly murder her husbands. She then turns to her father and tells him that he is also pitiful. She attacks him, exclaiming, 't'as l'air d'une vraie poule mouillante éjarrée là comme une vieille guénille!” (Beaulieu 55). ${ }^{178}$ Even more so, she wonders, “comment c'est faire que t'aurais pu occire mes hommes quand, toute ta vie, t'as fait le peureux, l'poltron, pis l'siffleux?... Quand que les Anglais sont v'nus... [...] Quand qu'les Anglais sont v'nus, pauvre p'tit pére, t'as même pas pus

\footnotetext{
175 The Woman-as-nation expresses a spatial and incarnated femininity: the fertility of the earth, on which people depend, must be protected against invasion and violation, thus by defending the limits of the body/nation.

${ }^{176}$ I'm not a little girl ... I'm capable of defending myself... I've been defending myself for years.

177 You're pitiful! ... You first, Mr. Justice, you're pitiful!

${ }^{178}$ You look like a real wimp, spread out there like an old rag!
} 
lutter de contre... Pis là les v'là partout..." (Beaulieu 55). ${ }^{179}$ In both instances, La Corriveau Noire attacks two paternal and patriarchal figures. Her father is portrayed as a typical Québécois man who tries to protect his daughter from a terrible outcome in court. However, in return, his daughter has no mercy for him. She considers her father, who represents Québécois society, a wimp. Although Beaulieu’s narrative jumps back and forth in time, situating events in 1754 when Marie-Josette married François, and then in 1763 when Ti-Oui was found dead in his barn, La Corriveau's comment about "quand qu'les Anglais sont v'nus" and her father's reaction refers to the immediate and direct outcome of the Battle at the Plains of Abraham: total defeat and the inevitable assimilation of the French Canadians to British culture since the British are now “partout.” After the British officers' conquest of New France, La Corriveau Noire wants to be liberated, and this desire speaks to Beaulieu's desire for a nationally liberated Québécois nation as well.

La Corriveau Noire's perception of her father as a powerless and emasculated man resonates with the popular depiction of colonized peoples as female, effeminate, or emasculated. Analyzing colonialism through a feminist lens, Roberts affirms that "the colonization process can clearly be seen as one of 'devirilization,' emasculation and,' according to the logic of misogyny, "reduction to the status of women (metaphorical femininity). Therefore, the movement towards decolonization involves the desire for full masculinity and the concomitant destruction of one's femininity" (20). Diane Lamoureux

\footnotetext{
${ }^{179}$ How could you have killed my husbands when all your life, you've been a coward, a wimp, a siffleux? ... When the British came... [...] When the British came, poor old dad, you couldn't even fight against them... And now here they are, everywhere... In addition to the translation, I wish to point out that the term siffleux is language specific. The word is characteristic of someone or something that hides (i.e., siffleux is often used in the sense of marmotte - a groundhog-, an animal that hides underground).
} 
creates an equivalence between what is female and "devirilized" or emasculated through her assertion that "when the emphasis is put on oppression, it is either gendered as female or an emasculated male" (199).

The devirilization of the Québécois man has been an ongoing trope over the centuries. Jeffery Vacante traces the state of Québécois manhood from the beginning of the twentieth century, through the Depression and past the Quiet Revolution, arguing that this phenomenon stems back to the Conquest. He writes, "the Conquest put an end to the colony's natural evolution toward statehood, some historians suggested, and instilled in French-speaking Canadians feelings of inferiority that discouraged them from competing with English-speaking Canadians for positions of leadership" (Vacante, National Manhood 5). Along with La Corriveau Noire's perception of her father as a coward, her husbands are portrayed as physically emasculated as they are unable to satisfy her sexually. She describes François as "toujours fatiqué, les oreilles molles pis sans rien d'ins jambes... Y avait pas fini d'souper qu'y sendormait tu suite” (Beaulieu 57). ${ }^{180}$ In claiming he has nothing between his legs and that he always falls asleep after supper, preventing any possibility of sexual intercourse during those evenings, La Corriveau Noire metaphorically castrates him. Her second husband, Ti-Oui, was even worse. She claims that he was always “dedans l'écurie ousqu'y pardait toute son temps à frotter sa maudite guevalle, à y tresser pi à y détresser la queue, dormant même dans l'foin à côté d'elle, restant là toutes les nuittes... toutes les nuittes!” (Beaulieu 63). ${ }^{181}$ Ti-Oui refuses

\footnotetext{
${ }^{180}$ Always tired, with soft ears and nothing in his legs... He wasn't done eating supper that he'd fall asleep right away.

${ }^{181}$ In the stable where he wasted all of his time rubbing his damned horse, braiding and unbraiding her tail, even sleeping in the hay beside her, staying there every night... every night!
} 
to share a bed with his wife, instead spending all of his time with his horse and sleeping on the hay beside the creature.

Ti-Oui's strange behaviour, which explicitly reveals an overidentification with rural Québec and labour as he sleeps with the horse in the barn, may be an allusion to Jonathan Swift's Gulliver's Travels. In Book IV, Gulliver returns home after his voyage to Houyhnhnm Land, a place where Houyhnhnms are intelligent and rational talking horses, and humans, called Yahoos, are enslaved. He is disenchanted with humanity and prefers spending his time with horses rather than his loved ones. Patricia Jones argues that Gulliver's insanity or mental instability at the end of the narrative results from his inability to revert back to a state wherein he may consider humans (Yahoos) superior beings, and horses (Houyhnhnms) inferior subjects (34). When viewed through a colonial lens, Ti-Oui's time in the stables would suggest that, like Gulliver, he is trapped in a state of halted oscillation between superior colonizer (as a descendant of French colonizers) and inferior colonized (as a descendant of those conquered by British colonizers). In other words, as a traditional Québécois, Ti-Oui is like a Yahoo who wishes he could identify with the dominant position of the colonizer represented by the superior Houyhnhnm, and also implicitly, by the British. Ti-Oui therefore embodies the state of the traditional Québécois man as a colonial subject in three ways: first, like Joseph Corriveau, Ti-Oui is the emasculated male, and this emasculation equates him to the female, colonized subject; second, his obsession with the barn and horse associates him with the traditional, rural Québec, thereby likening him to the female Corriveau Blanche who symbolizes traditional Québec; and third, his resemblance to Gulliver demonstrates how he suffers from false consciousness since, neither able to believe that French 
Canadians are the superior colonizers nor embody the superior British position, he accepts the colonizer's claim that he is inferior.

The two Corriveaus' respective desires in relation to the men in their lives highlight La Corriveau Noire's alterity and reclamation of her wantonness. Whereas La Corriveau Noire calls her father a "poule mouillée," La Corriveau Blanche cries over the death of her husband, claiming that when she turned the deceased François around in his bed, he was "p'tit, p'tit, comme un p'tit poulet d'printemps" (Beaulieu 61). ${ }^{182}$ The "p" alliteration and the repetition of the sound "ptit" make François seem small and vulnerable. ${ }^{183}$ Indeed, when the two Corriveau figures speak consecutively, they create a conflation between the father figure and the husband figure. In addition to the "poulet" that connects Joseph Corriveau to François, the image of big, strong, manly hands acts as a motif that blurs the lines between paternal and incestuous love. La Corriveau Blanche recalls and longs for 'la main d'mon pére sus mon ventre, pour que j'm'endorme... la main d'mon pére déf'sant mes tresses, pour que j'm'endorme... la main d'mon pére sus ma joue, pour que j'm'endorme" (Beaulieu 64). ${ }^{184}$ This memory of Joseph Corriveau undoing his daughter's braid and watching her sleep recalls Ti-Oui and the horse he braids and sleeps beside. La Corriveau Blanche aspires to remain a "daddy's girl" until she marries. Before Ti-Oui's death, she still hoped that he 'r'viendrait à meson pis j'le f'rais manger... pis y m'parl'rait d'sa guevalle... pis j'voudrions jusse être bonne avec

\footnotetext{
${ }^{182}$ Small, small, like a small spring chick.

${ }^{183}$ In Québécois linguistic variations, this syllable might even sound like more like "ptsi," bringing the sound closer to a chick's chirp.

${ }^{184}$ My father's hand on my stomach, so that I fall asleep... my father's hand undoing my braids, so that I fall asleep... my father's hand on my cheek, so that I fall asleep.
} 
lui" (Beaulieu 65). ${ }^{185}$ With her husband, she hoped to be a nurturing housewife who would tend to his needs_—what La Corriveau Noire calls being "une esclâve!” (Beaulieu 57). ${ }^{186}$ La Corriveau Noire closes this gap between paternal and incestuous love in the following lines by placing the male hands in a sexual context. She wishes for "des belles grandes mains d'homme!... Des vraies mains d'homme!... Des mains pour me toucher dans mes tétons, pour me toucher dans mon ventre, pour me toucher dans mon minou, pour me toucher dans mes fesses" (Beaulieu 64). ${ }^{187}$ Evident through this comment are tensions that animate the dual presentation of La Corriveau. La Corriveau Noire fantasizes about waiting for her husband, “pour qu'y s'jette dessus moi, pour qu'y morde, pour qu'y m'liche... J'vouions crier, j'voulions hurler, j'voulions êt'e toute en sueurs, toute essoufflée, toute heureuse dans mon corps!” (Beaulieu 65). ${ }^{188}$ This lustful Corriveau does not want to tend to men, but wants men to tend to her. As such, whereas La Corriveau Blanche represents the traditional Québécois woman, the submissive daughter that eventually becomes the submissive wife and the one who preserves the retrograde colonial state of Québec, La Corriveau Noire wants to be selfish, to embrace her female body and sexuality, and to see a nationally liberated Québec.

At the end of the play when La Corriveau Noire receives her death sentence, she chants, “toute le Kébec est éclairé jusque dans ses fond'ments!... L’esclavage est fini, la peur est finie, la répression est finie! ... Moi la Corriveau, j’vas r'virer l'Kébec à

\footnotetext{
${ }^{185}$ Would come home and I would make him supper... and he would talk to me about his horse... and I would just be good to him.

${ }^{186}$ A slave!

${ }^{187}$ Nice big man hands!... Real man hands!... Hands to touch my breasts, to touch my stomach, to touch my pussy, to touch my ass.

${ }^{188}$ That he throws himself at me, that he bites, that he licks me... I want to yell, I want to scream, I want to be sweating, panting, happy in my body!
} 
l'envers!" (Beaulieu 79). ${ }^{189}$ La Corriveau Noire makes bold statements over the course of the play that certainly convey nationalist sentiments and a militant spirit, confirming Slott's claim that Beaulieu “n'essaie pas tant de disculper la Corriveau, mais plutôt de la transformer en modèle de résistance contre le colonialisme socio-linguistique et culturelle" (155). ${ }^{190}$ La Corriveau Noire's aggressive sexuality, which contrasts her with the spineless and sexually inadequate men, allows her to assume the political role of the virile Québécois male while never losing her association with the woman-as-nation trope. The slavery, fear, and repression will only end if La Corriveau succeeds in transvaluing the woman-as-nation trope with feminism, but as we will see shortly, the play sets itself up for failure.

Beaulieu complicates the dynamics between colonized and colonizer by extending the issue beyond the gendered borders of female and male to the cultural borders between French and English. With Tom Caribou acting as the judge in the re-enactment of MarieJosette's trial, Beaulieu conflates self and other, placing the Québécois man in the position of the British figure (as we will see later, there is a similar occurrence in Hébert's La cage wherein the Québécois and British men are conflated into a shared position of blame that echoes Homi Bhabha's concept of mimicry wherein the colonized behaves like the colonizer). While Les anciens Canadiens and The Golden Dog clearly narrate the loss of New France at the hands of the British soldiers (whether it is depicted as tragedy or salvation), Ma Corriveau's juxtaposition of Québécois and British men

\footnotetext{
${ }^{189}$ All of Québec is enlightened to its very foundations! ... The slavery has ended, the fear has ended, the repression has ended! ... I, La Corriveau, will turn Québec upside down!

${ }^{190}$ Does not attempt to exonerate La Corriveau, but rather to transform her into a model of resistance against socio-linguistic and cultural colonialism.
} 
suggests once again that the Québécois men are the ones to blame for the defeat at the Plains of Abraham and ultimate downfall of the colony. This conflation is particularly striking considering the language the judge adopts. When he pronounces the two verdicts, the first ordering Marie-Josette to be lashed and branded on the hand for her crimes, and the second time ordering her execution and hanging in a gibbet, he ends his sentencing with "la Justice anglaise est juste!" (Beaulieu 53, 68). ${ }^{191}$ This polyptoton reveals the judge's absolute power as an Englishman.

The incorporation of the judge's line about English justice ironically highlights the incongruous notion of a just English system, as well as the beginnings of the disputes between the French Canadians and the British concerning the former's rights to retain and practice their language, religion, land tenure system, and law after the Conquest. In providing context to the Corriveau trials that occurred in March and April of 1763, Ferland and Corriveau write that "pendant cette période de transition que constitue le régime militaire, les lois françaises cessent évidemment de prévaloir dans la colonie, remplacées par le code pénal et les procédures britanniques" (83). ${ }^{192}$ In contrast, Pierre-E. Audet argues that during the transitional period between 1760 and 1763, although a military government was in power, "la procédure et la loi suivies étaient françaises. Toute cette organisation judiciaire n'avait de militaire que le nom" (28). ${ }^{193}$ Donald Fyson supports the latter statement and affirms that under the French regime, which "was

\footnotetext{
${ }^{191}$ English justice is just!

${ }^{192}$ During this transitional period that was the military regime, French laws evidently ceased to prevail in the colony, replaced by the penal code and British legal procedures.

193 "In terms of judicial organization, it was military in name only. In everyday life, the French laws and procedures continued to apply" (translation provided by the Ministère de la justice de Québec's webpage called "Historical Note").
} 
maintained during the military regime" (383), the Canadian colony followed judicial procedures similar to the civil code in France, mostly abiding to the Coutume de Paris (the Custom of Paris). The judge, as a Québécois character embodying Englishness, reflects the complexities surrounding the inhabitants' rights to practice law under their own judicial system during this unstable period in history.

Indeed, it is important to keep in mind that Tom Caribou is an actor performing the role of the English judge. He is unmistakably Québécois; when he speaks, he uses contractions, pronunciation, and profanity that are specific to the Québécois variation of the French language: “le pays est rempli d'malfaiteurs de vot'e espèce! ... Faut qu'la loâ et l'ordre règnent, baptême! ... Les Canayens, toutes pareils! Des buveurs, des courailleux d'jupons, des batailleurs... des séparatisses!” (Beaulieu 44). ${ }^{194}$ Scholars such as Gilles Dorion maintain that there is a distinct Québécois quality to Beaulieu's writing, as exemplified in the passage above. Dorion writes, "le vocabulaire, quant à lui, se ressent de la québécitude de l'auteur, qui, sciemment, utilise des termes québécois (ou des déformations phonétiques) à plusieurs reprises, pour désigner les réalités d'ici”' (49). ${ }^{195}$ Similarly, Laurendeau argues that "cette pièce, écrite en joual, redonne à notre parlure d'antan ses lettres de noblesse" and that "notre langue vernaculaire ... est un des fondements historiques de notre identité" (32). ${ }^{196}$ The language that Tom uses is specifically joual and difficult to translate, which draws attention to the fact that Tom

\footnotetext{
194 The country is filled with wrongdoers of your kind! ... Law and order must prevail, baptême! ... Canadiens, all the same! Drinkers, womanizers, fighters... separatists!

195 The vocabulary itself emanates with the québécitude of the author, who consciously employs Québécois terms (or phonetic deformations) in many instances, to designate the realities of this place.

196 This play, written in joual, gives back to our spoken language of old its noble letters ... our vernacular language ... is one of the historical foundations of our identity.
} 
only performs the role of an Englishman. In collapsing the Québécois man and the British one, Beaulieu dramatizes a long-lasting debate about Québec's colonial condition. On the one hand, the presence of the judge and his role in sentencing Marie-Josette to her death, and the implicit sentencing of the French-Canadian habitants to an eternal colonial condition through the presence and role of La Corriveau Blanche, advances the thesis that Québec's inferior state was caused by the British and originated in the Conquest of 1760. On the other hand, Tom's indisputable Québécois roots, his “québécitude,” and language all symbolize "l'autre grande variété explicative [qui] consiste justement à imputer aux Canadiens français eux-mêmes la responsabilité de leur infériorité économique. Cette autocritique proliférait, durant les années 1950 et 1960, chez les intellectuels de diverses tendances idéologiques et politiques" (F. Roy 37). ${ }^{197}$ As such, much like Marie-Josette who is split into two beings-La Corriveau Blanche who perpetuates the inferior condition of women in Québec and the colonial condition of the nation, and La Corriveau Noire who seeks a revolution to change the future of Québécois men and women alikeTom embodies not only the two potential causes of this Québécois condition, but the fundamental paradox of Québec's colonized status: the British who conquered New France, and the French Canadians who succumbed to British power.

By the end of the trial, La Corriveau Noire has admitted her crimes, and the judge sentences her to death by hanging in chains. The latter removes his mask and joins his friends. Once the re-enactment of Marie-Josette's story is over, the narrative returns to the second level of the frame narrative with Jos and his companions. Frightened by the

\footnotetext{
197 The other big explanation [that] precisely consists in imparting onto the French Canadians themselves the responsibility for their economic inferiority. This self-critique proliferated, during the $1950 \mathrm{~s}$ and 1960s, among intellectuals of diverse ideological and political inclinations.
} 
Corriveau legend, they are about to head out to a bar when "Jos Violon fait encore claquer ses doigts. Les personnages lèvent les jambes sur place, repris par la magie. Une musique étrange se fait entendre et une lueur apparât" (Beaulieu 69-70). ${ }^{198}$ Suddenly, Zèbre Roberge comes running and narrates his encounter with La Corriveau. This final section of the play, which reads like a second act, functions as an intertextual reference to the passage involving the figure of La Corriveau in Les anciens Canadiens. Paterson divides the level of énoncé/narration into two categories. The first, as we saw, pertains to the diegesis. The metafictional elements of Ma Corriveau's diegesis were mainly expressed through the double frame narrative and character doubles. The second category within the énoncé/narration refers to what Paterson calls "code," which describes a system of signifiers wherein metafiction can be expressed (Moments postmodernes 31). With respect to the code, Ma Corriveau expresses its metafictionality through an intertextual reference to de Gaspé's novel. As a rewriting of the Corriveau sections of de Gaspé's novel, Zèbre explains to his friends how La Corriveau tries to convince him to help her cross the Saint Lawrence River. This passage is written in a similar and recognizable literary style, aside from the use of Beaulieusien language. Zèbre begins describing his encounter by saying 'toute d'un coup, y m'semble entend'e comme qui dirait une plainte... Mais comme y vente un gros sorouet, j'cre que c'est l'vent qui m'siffle d'ins os du calâbre" (Beaulieu 71). ${ }^{199}$ His account of the story mirrors José Dubé's narrative as the servant details, "quand il [son père] passa près de l'esquelette, il

\footnotetext{
198 Jos Violon snaps his fingers. The characters' legs rise on the spot, enchanted by magic. Strange music is heard, and a light appears.

199 All of a sudden, I thought I heard a sort of a wail... But as a heavy southwest wind was blowing, I thought it was the wind whistling through the bones of the corpse.
} 
lui sembla bin entendre quelque bruit, comme qui dirait une plainte; mais comme il venait un gros sorouè (sud-ouest), il crut que c'était le vent qui sifflait dans les os du calâbre (cadavre)" (de Gaspé 33, italics in original). ${ }^{200}$ This resemblance in the narratives transpires throughout the latter part of Beaulieu's work. For instance, whereas La Corriveau exclaims to François Dubé, “mon cher François ... si tu refuses de m’y mener en chair et en os, je vais t'étrangler; je monterai sur ton âme et je me rendrai au sabbat" and "ce disant, elle le saisit à la gorge et l'étrangla" (de Gaspé 45), La Corriveau proclaims to Zèbre, “eh l'Zèbre mon zami... si tu r'fuses de m'ner sus l'Île d'Orléans en chair pis en os, j'vas t'étriper, j'vas monter sus ton âme, pis j'vas m'rendre de même au sabbat!" (Beaulieu 75-6). ${ }^{201}$ Then, according to Zèbre, “elle a pas dit ça qu'a m'saute à gorge pis qu'a l'assaye de m'étouffer" (Beaulieu 76). ${ }^{202}$ In rewriting de Gaspé's story using numerous postmodern techniques, Beaulieu shows his indebtedness to the first literary text on the legend of La Corriveau, likening his text to Les anciens Canadiens all the while paradoxically dissociating his rebellious Corriveau figure from the witch that supported French- and English-Canadian romantic nationalism.

Such intertextuality raises questions concerning the use of gothic elements in Beaulieu's play. As I explained in Chapter Two, nineteenth-century writers such as de Gaspé and Kirby created frightening narratives, drawing on gothic elements including the

\footnotetext{
200 "As he was passing the skeleton, he thought he heard a noise, a sort of wailing; but, as a heavy southwest wind was blowing, he made up his mind it was only the gale whistling through the bones of the corpse" (39, translated by Charles G.D. Roberts).

201 "My dear Francis ... if your body and bones won't carry me over, I'm going to strangle you. I will straddle your soul and ride over to the festival. ... with these words, she seized him by the throat and strangled him" (53, translated by Charles G.D. Roberts). ... hey there, Zèbre ol' pal... if you refuse to bring me to the Île d'Orléans with your flesh and bones, I'll strangle ya, I'll climb onto your soul, and I'll get to the sabbath that way!

${ }^{202}$ She barely finished talking that she jumped up my throat and tried to choke me.
} 
harassing, gibbeting skeleton and the poisonous-witch-turned-hired-assassin to present La Corriveau as a gothic revenant that symbolized obstruction to Canada's national unity. In other words, the figure of La Corriveau epitomized in these texts the tensions animating a figure of otherness that simultaneously supported and resisted the assimilation of French Canadians and various cultural others into English-Canadian culture. Rather than act as a revenant in Ma Corriveau, Marie-Josette's “splintering of self is a gothic presence that uncannily represents a conceptualization of identity, not as stable unified subjectivity, but as vulnerable to ruptures and divisions. The spectre of the double found throughout gothic literature is, in essence, part of a more general discursive pattern of fluid identity within the gothic" (J. D. Edwards xxiv). Beaulieu therefore offers a new kind of Québécois gothic that is perhaps not as frightening, but equally as threatening as its nineteenth-century iteration; the presence of two Corriveau figures reveals the fluid, yet irreconcilable, identity of a Québécois nation that is torn between conservatism and revolution. Through La Corriveau Noire, the repressed returns in these postmodern gothic moments as the Québécois' refusal to remain repressed/oppressed within the EnglishCanadian nation-state. This robust refusal is evident in Beaulieu's rewriting of the de Gaspé passage. Whereas de Gaspé's witch waits to finish her sentence before strangling François (“ce disant, elle le saisit à la gorge et l'étrangla"), Beaulieu's witch refuses to remain passive. She is restless and hasty, choking Zèbre before finishing her sentence (“elle a pas dit ça qu'a m'saute à gorge pis qu'a l'assaye de m'étouffer”). La Corriveau Noire is highly threatening because she transgresses the boundaries between what is and what is not acceptable; she does not comply with "British authorities" such as Tom 
Caribou, but bewitches everyone in her quest to liberate Québec from its colonial condition.

As Zèbre ends his story, all of the characters hear an enchanting song, "le chant que chantent les Corriveau qui sont dans une petite cage entre ciel et terre. Même que la Corriveau blanche pourrait être recroquevillée dans la cage. La Corriveau noire, elle, pourrait être assise dessus la cage" (Beaulieu 77). ${ }^{203}$ Remodelling de Gaspé's song “c'est notre terre d'Orléans (bis) / Qu'est le pays des beaux enfants" (de Gaspé 37, italics in original), La Corriveau Blanche and La Corriveau Noire sing,

C'est not'terre de Québec

C'est not'terre de Québec

Qu'est l'pays des beaux enfants! (Beaulieu 78) 204

Intertwined in these lyrics is La Corriveau Noire's speech about ending the oppression and turning Québec upside down. La Corriveau Blanche's imprisonment in the cage indicates that she is no longer free to come and go as she pleases; it symbolizes the imprisonment of the retrograde Québec, its traditional values and "faiblesse culturelle" (Lanthier 112). La Corriveau Noire has become the dominant of the two, and with the help of the bewitched men, she initiates a revolution. Substituting the lines "c'est notre

\footnotetext{
${ }^{203}$ The chant that sing the Corriveaus, who are in a little cage between heaven and earth. What is more, La Corriveau Blanche could be curled up in the cage. La Corriveau Noire could be sitting on top of the cage. In addition to the translation, I would like to point out that when the characters first hear the Corriveau's song, they are immediately under her spell, despite Zèbre's warning to block their ears to avoid being bewitched. In this context, La Corriveau compares more to a siren than a witch figure. As we will see in Chapter Four, Glover also presents the Corriveau figure as a seductive siren that enchants men.

${ }^{204}$ This is our land, Orléans (bis) / That is the country of nice children. This passage from Les anciens Canadiens refers to the moment La Corriveau brings François Dubé to the Île d'Orléans. One of the sorcerers on the island sings this song. Charles G.D. Roberts translates these lines as "Here's the spot that suits us well / When it gets too hot in hell" (43). Beaulieu's version translates to: It's our land, Québec / It's our land, Québec / That is the country of nice children!
} 
terre d'Orléans," the land of the sorcerers and other supernatural creatures in Les anciens Canadiens, all of the characters in Beaulieu's play shout "c'est not'terre de Québec" in reclamation of their land. In contrast to the judge's assertion that "la Justice anglaise est juste!" (Beaulieu 53, 68), La Corriveau offers an alternative form of justice against British invasion with "oeil pour oeil!... Dent pour dent!" and implies that all the strength and power that animates her nationalist endeavour come from "la magie [qui] est Kébécoise!" (Beaulieu 80). ${ }^{205}$ La Corriveau Noire's radically subversive speech makes her appear psychotic and deranged. As Paterson observes, ce lien entre l'altérité, l'étrangeté et la folie est évidemment lourd de significations et de conséquences. Ce qu'il met en pleine lumière, c'est évidemment la peur de l'Autre : peur de ce qui dépasse les limites acceptables de l'altérité; peur aussi de se détacher à tout jamais, par le truchement de l'Autre, du groupe de référence, du nous-mêmes qui confère au sujet son identité et son appartenance. (Figures de l'Autre 35-36) 206

If La Corriveau Noire is portrayed as a threatening figure who will bring evil to the nation, it is because there is a fear of change among the Québécois. Put in this context, Paterson's assertion would suggest that La Corriveau Noire is a figure of otherness representing that which is completely alien to both the traditional Québécois man and woman. Beaulieu imagines a new type of gothic that necessitates a terrifyingly radical revolution; there is a fear of the unknown, embodied in La Corriveau Noire, of a new

\footnotetext{
${ }^{205}$ English justice is just! ... an eye for an eye!... A tooth for a tooth! ... the magic [that] is Québécois!

206 This relationship between alterity, strangeness, and folly is evidently strong with significance and consequence. It evidently sheds light on the fear of the Other: fear that it transgresses the acceptable limits of alterity; fear as well of being permanently detached, through the Other, from the referential group, from the 'us' that confers identity and a sense of belonging to the subject.
} 
Québec and a new Québécois figure completely detached from its previous, "comfortably oppressed" iterations.

While La Corriveau has undeniably become a potent symbol for Québec nationalism and feminism, Jos Violon's erasure of the revolution with the snap of his fingers at the end of the narrative shows how the Québécois people may not yet be ready for this change. As the bewitched characters are seduced by La Corriveau Noire's words about a new Québec where “l'orgie, la débauche, toutes les vices apparaissent!... Le Mal, le mal, enfin le Mal!" (Beaulieu 80), Jos reveals the impossibility of a Québec filled with vice and evil when he tells the audience, “c'est ça que j'aurions aimé vous racon'ter mes bonnes gences" $(80){ }^{207}$ His statement reveals his desire for a reformed Québec, one that for the time being, he can only imagine and share as un conte that might never be concretized. Indeed, Jos concludes the play by again bringing attention to the fictitious nature of the various stories embedded within the play, and by explaining what happened to the figure of La Corriveau and her cage. He reasons that after its exhumation, the gibbet disappeared, but that “pour pas effaroucher l'monde, les autorités y l'ont faite disparaitre une aut'fois, par rapport à la sécurité nâtionâle qu'y disaient" (Beaulieu 81). ${ }^{208}$ These final lines enable La Corriveau's transformation from a witch or poisoner that consolidated Canada's English-Canadian romantic nationalist project into a truly threatening figure, not one that can easily be subsumed like the Indigenous other in the nineteenth-century versions of La Corriveau, but one that seeks to subvert Québec's

\footnotetext{
${ }^{207}$ Orgies, debauchery, all vices appear! Evil, evil, finally the Evil! ... that's what I would have liked to tell you, my good folks.

${ }^{208}$ To avoid frightening people, authorities made it disappear again, related to national security, they said.
} 
colonial and feminized state to make it a sovereign and independent nation. Yet, her disappearance after Jos snaps his fingers symbolizes her silence and calls to attention the paradoxes at the heart of Beaulieu's work.

Through La Corriveau Blanche's imprisonment and La Corriveau Noire's triumph at the end of the play, Beaulieu dramatizes the successful sexual and national liberation of Québec, if only for a moment. Arguably, though, neither Corriveau figure is successful in the end and Jos will never see his Québécois dream concretized. Despite Beaulieu's attempts to transvalue the woman-as-nation trope with feminism through La Corriveau Noire, the play implies that the nation's failed liberation is due to the continuous exclusion of women from the liberation movement. While La Corriveau Noire appears as a feminist symbol through her transvaluing of the woman-as-nation trope with feminism, the female voice never truly exists in Ma Corriveau. Jos Violon controls the narrative and gives voice to Marie-Josette deep within the third narrative of the play (in the secondorder nesting that turns the "second" nested narrative into another frame narrative). Indeed, Beaulieu's ideologies as dramatized in his play align closely with those of the Parti pris, a literary and political group active in the 1960s whose written works often presented women as objects rather than subjects. ${ }^{209}$ Lanthier argues that whether it is "à travers les articles de la revue Parti pris ou les romans de Jacques Godbout ou Hubert Aquin ... La signification des symboles, des idées et des mots rattachés au pays, à

\footnotetext{
${ }^{209}$ Founded in 1963, Parti pris was a political and cultural magazine active between 1963 and 1968. Many participants were young activists and intellectuals who believed in the mainstream ideologies of the time: Marxism-Leninism (which contributed to the group's gendered thinking), Sartrean existentialism, and Third World decolonization (Major). As Robert Major notes, in addition to being a magazine, Parti pris was also "an avant-garde revolutionary centre which was active in demonstrations, the training of militants, the Club Parti pris and later the Mouvement de libération populaire" (Major). The publishing house Éditions Parti pris continued to operate after 1968 (Major).
} 
l'aliénation, à la décolonisation, à la révolte et à la libération, reflète une articulation basée sur la libération de « l'» homme au dépens de « la » femme" (80). ${ }^{210}$ Scholars such as Lanthier and Lori Saint-Martin have examined Beaulieu's works including Jos Connaissant (1970) and Un rêve québécois (1972) from this perspective since both novels explore the notion of a nationally liberated Québec by exploiting themes of sexual violence and murder. ${ }^{211}$ When discussing the latter novel, Beaulieu explains that the work was “une interrogation sur ce phénomène d'inconscience collective des Québécois en 1970. ... Quand on ne peut pas décider politiquement de ce que l'on est, quand on se complaît dans une situation d'infériorisation, quand on est terrorisé par plus grand que soi, la réponse directe à ça, c'est qu'on veut terroriser quelqu'un de moins fort que soi” (Beaulieu and Atwood 201). ${ }^{212}$ Through his allegorical use of gender dynamics, Beaulieu therefore reveals a necessity to overpower the inferior, feminized individual.

Although Ma Corriveau does not depict any violence or death (aside from that of the two husbands), Beaulieu likewise instrumentalizes the female figures in this play as symbols for Québec's national liberation, whether it is in support of, or resistance against, the movement. This objectification of La Corriveau Blanche and La Corriveau Noire “rédui[t] la femme à n'être plus qu'un symbole [et] revient à nier qu'elle existe en tant

\footnotetext{
210 Through the articles of the Parti pris or the novels of Jacques Godbout or Hubert Aquin ... The significance of symbols, ideas, and words attached to the nation, to alienation, to decolonization, to revolt, and to liberty reflect an articulation based on the liberation of 'the' man at the expense of 'the' woman.

${ }^{211}$ In Jos Connaissant, Jos seeks to liberate himself by losing his virginity to Marie Rousseau, a waitress who used to be an exotic dancer. His desires are incestuous since he sees Marie as a mother figure and he ends up mutilating her female body. In Un rêve québécois, the protagonist, Joseph-David-Barthélémy Dupuis, rapes and murders his wife, Jeanne-D'Arc.

212 An examination of the phenomenon that was the Québécois' collective unconsciousness in 1970. ... When we cannot decide what we are politically, when we comply to a situation of inferiority, when we are terrorized by something bigger than ourselves, the direct response to that is that we want to terrorize someone weaker than us.
} 
qu'être humain autonome" (Lanthier 117). ${ }^{213}$ Both Corriveau figures still function as national symbols of Québec whose bodies are offered up as boundaries needing to be transgressed. Whereas La Corriveau Blanche, who represents Québec's assimilation to English Canada and can easily be substituted with Joan from Aquin's Trou de mémoire (1968) or Jeanne-D'Arc from Beaulieu's Un rêve québécois, would need to be forcibly transgressed — or aggressed - to illustrate the symbolic death of a traditional, colonial Québec, La Corriveau Noire, who represents a nationally liberated Québec, forcibly wills this sexual transgression, as expressed through her sexual desires. Ironically, while La Corriveau Noire is upfront and honest about her carnal desires, this openness makes her a disagreeable and disturbing character. In part, her forwardness can be seen as debilitating — even paralyzing— the Québécois people. La Corriveau Noire does not really incite anyone to want to participate in her liberation movement and thus guarantees her own failure. Consequently, neither La Corriveau Blanche nor La Corriveau Noire is able to transcend the boundaries between an old and new Québec, between colonial and liberated, or masculine and feminine. As we will see in the following section, Hébert similarly focuses on Québécois nationalism and feminism in La cage, but is more successful at transforming the figure of La Corriveau into what Smart calls the "womansubject," not by transvaluing the woman-as-nation trope with feminism as Beaulieu does, but by rewriting the tradition of "la mère québécoise."214

\footnotetext{
being.

${ }^{213}$ Reduce[s] the woman to a mere symbol [and] comes to deny that she exists as an autonomous human

${ }^{214}$ Smart uses the term "woman-subject" sporadically in Writing in the Father's House: The Emergence of the Feminine in the Quebec Literary Tradition (1991).
} 


\subsection{Transforming (M)Otherhood through New Af/filiations in La cage}

Hébert was born on August 1, 1916, at Sainte-Catherine-de-Fossambault, QC (now called Sainte-Catherine-de-la-Jacques-Cartier). To say that she is a "figure majeure de la littérature québécoise" is an understatement as according to the Centre Anne Hébert at the Unversité de Sherbrooke, she is "l'auteure Québécoise la plus étudiée dans le monde" (Watteyne et al.). She wrote numerous novels, poetry, nouvelles, and plays. Some of her best-known works include Le torrent (1950), Kamouraska (1970), and Les fous de Bassan (1982). After her mother passed away in 1965, she moved to Paris and only returned to Montreal in 1998. She died on January 22, 2000. ${ }^{215}$

In contrast to Beaulieu, whose works are at times "à l'opposé de la quintessence de la femme, c'est-à-dire de sa présence essentielle dans le déploiement de l'humanité" (Laurendeau 21), Hébert, "quelles que soient ses convictions, ses textes poétiques, romanesques ou dramatiques témoignent d'une subjectivité féminine, allant souvent jusqu'à un regard féministe" (Dupré 156). ${ }^{216}$ Hébert's adaptation of the legend of La Corriveau, La cage (1990), “déconstruit le centre et l'unité d'une vision historique traditionnelle pour en valoriser les marges et la multiplicité des points de vue" (Lahaie 94-95). ${ }^{217}$ Hébert translates the folkloric legend of La Corriveau, which is temporally grounded in the time of the British Conquest of 1760, into a relevant, contemporary narrative that engages in the subversion of patriarchal structures and serves as "an

\footnotetext{
${ }^{215}$ See Nathalie Watteyne et al's Anne Hébert : chronologie et bibliographie des livres, parties de livres, articles et autres travaux consacrés à son œuvre (2008).

${ }^{216}$ At the opposite of the quintessence of the woman, that is to say, of her essential presence in the deployment of humanity. ... whatever her convictions, her poetic, fictional, and dramaturgical works express female subjectivity, often even presenting a feminist outlook.

${ }^{217}$ Deconstructs the centre and unity of a traditional view of history in order to value the margins and the multiplicity of points of view.
} 
apologia for women throughout history who have been marginalized and judged scandalous because they were objects of desire, underscoring the boldness and heroism of their independence, and the contradiction and hypocrisy of patriarchal attitudes" (Reid 140). Through Hébert's play, La Corriveau transforms from a figure evoking fear into one overcoming fear.

Such transformation is possible through the rewriting of La Corriveau into a nurturing mother figure, an image that has been reclaimed and reimagined by feminist writers to challenge the patriarchal stereotype of the "Bad Mother." Commenting on the relationship between Ludivine (Hébert's Corriveau figure) and the legend of La Corriveau, McBride explains that the construction of a maternal Corriveau figure goes against previous versions of the witch figure. She asserts, "adoptive motherhood proves extremely detrimental to the vision offered by previous adaptations of La Corriveau as antithetical to kindness or love, as it reinstates and amplifies maternal, nurturing qualities that the traditional myth expunged" (McBride 135). She adds that Ludivine is "the French-Canadian mother par excellence" despite her infertility and is actually transformed into an almost super-maternal figure, as compared to those women whose families are created out of duty and fear. In this way, Anne Hébert not only reconceives La Corriveau's family, but also offers a depiction of motherhood that rejects the "coercive maternity" prevalent in women's theatre at the time that Hébert wrote the play. (McBride 136)

Hébert's mother figure opposes the "Bad Mother" stereotype that signified the "retrograde rural and religious values" of Québec (Roberts 21) and the "Castrating Mother" that prevents her son from fulfilling his quest for emancipation, whether it be at 
the individual or national level. Like Beaulieu's La Corriveau Noire, Ludivine is defiant; the latter stands against patriarchal figures such as Crebessa and Elzéar, transcending various cultural, linguistic, and national borders. However, rather than using her body to transgress borders sexually, Ludivine's body is de-instrumentalized, and her infertility is what enables her to nurture her community at large. Although La cage might appear more feminist than nationalist, as Slott and McBride have argued, Ludivine's virtuous embodiment of motherhood is intrinsically related to nationhood. I argue that Hébert's rewriting of the mother figure through her characterization of Ludivine offers a new version of the woman-as-nation trope that is based on affiliation rather than filiation. In doing so, Hébert offers a new vision of Québec based on a model of nationhood that is liberated by women, and liberated through its conceptualization of affiliative bonds.

Despite what I consider the success of Hébert's non-binary, affiliative thinking, which I will attempt to demonstrate throughout this section of the chapter, it is important to keep in mind that while this feminist model of nationhood serves some feminisms well, it might be less productive for other marginalized women in Québec. Daiva Stasiulis and Radha Jhappan argue that Québécois feminism concerns white, francophone, Québécois women. They write, "the concerns and identities of First Nations women, immigrant and racial minority (francophone, anglophone, and 'allophone'), and Anglo-Canadian women in Québec are relatively marginalized at this level of women's politics” (Stasiulis and Jhappan 125). White, francophone, Québécois women rally around their identity as women who are nationally and linguistically oppressed by English Canada, but struggle to "come to terms with the racial/ethnic exclusions flowing from their involvement as the mothers and shapers of a subordinate white settler society" 
(Stasiulis and Jhappan 126). ${ }^{218}$ Ludivine and Rosalinde's duality does, in fact, reveal complicity among francophone women from different cultures, but continues to promote solidarity among white women. As such, while Hébert's literary work advances feminism through Ludivine's victory at the end, one ought to keep in mind that much remains to be said within, and outside, the realm of the legend of La Corriveau about other feminisms.

La cage is not a literary work that is exclusively available to francophones. It was translated into Portuguese as A gaiola de ferro in 2003 by Nubia Hanciau and published by Editora da FURG in Rio Grande, Brazil. In 2010, Pamela Grant and Gregory J. Reid translated La cage into English, and Sheila Fischman translated L'île de la Demoiselle (also into English), a radio play that aired on France Culture in 1974 and 1977 and subsequently appeared in the journal Écrits du Canada français in 1979 (Watteyne et al.; Hébert 116). Together, these plays were published as Two Plays: The Cage and L'île de La Demoiselle by Playwrights Canada Press in Toronto. In contrast to L'île de la Demoiselle, which won Hébert the TNM (Théâtre Nouveau Monde) first prize for epic theatre in 1994 and comprised a $\$ 5000$ bursary, a public reading on the Théâtre du Nouveau Monde stage in Montreal, an English translation of the work, and a public reading at the anglophone theatre in Montreal called the Centaur Theatre (Watteyne et al.), La cage has received little media attention or public interest. There is a fair amount of scholarship on the subject, but aside from a few performances in Canada by amateur theatre groups (Reid and Grant iii), the play has yet to be performed professionally even though it is clear through "the taut dialogue of her plays and their detailed directions for production on stage or radio show that Hébert created her pieces to be performed"

${ }^{218}$ See Stasiulis and Jhappan's "The Fractious Politics of a Settler Society: Canada" (1995). 
(Forsyth $\mathrm{x}$ ). Concomitantly with le nouveau théâtre québécois that focused on theatrical "rebirth at the hands of Man" (Hurley 60), there was a collective feminist theatre movement in Québec called le théâtre des femmes, also known as le théâtre au féminin, which began in the sixties and gained prominence in the mid-1970s (Desroches; Moss, "Le corp(u)s théâtral des femmes"). Jane Moss explains that feminist playwrights typically avoid writing on idolized figures symbolic of an official history of Québec, especially historical women who "have become symbols of the patriarchal ideals of female self-sacrifice and sexlessness" ("Women, History, and Theater in Quebec" 976). The small number of "plays that recast historical and legendary female figures have not been produced on the stage, either because they were written as radio plays or because of challenges posed by large casts, set changes, and supernatural elements" (Moss, "Women, History, and Theater in Quebec" 976). Moss affirms, for instance, that L'île de la Demoiselle has never been staged in Québec and that La cage is "difficult (and expensive) to stage" because of the supernatural elements including the white and black fairies, the seven deadly sins, and the dual plotline of the Old and New Worlds ("Women, History, and Theater in Quebec" 977).

Hébert's play begins with the birth of two baby girls: Ludivine, who later becomes the Corriveau figure by taking her husband's last name; and the other is Rosalinde, an upper-class English woman and future wife of the judge John Crebessa. The stage directions specify that when the two babies are born, Babette, the narrator and Ludivine's adopted daughter, must "trace[r] un trait de craie blanche au milieu de la scène" and again, "repasse[r] avec sa craie sur le trait tout à l'heure tracé" (Hébert 14- 
15). ${ }^{219}$ She claims it is important for her to "délimite[r] nettement les territoires" and that “tout demeure clair, le nouveau monde à droite, l'ancien monde à gauche” (Hébert 1415). ${ }^{220}$ Ludivine's birth is therefore an act of origination that creates a border with predetermined hierarchies. Hébert's use of a binary is very telling: Rosalinde from the Old World, is placed on a magnificent cushion carried by a nursemaid. Her richly dressed parents are beside her. On the right side, Ludivine is dressed in rags, cradled in her poor parents' arms. Rosalinde and Ludivine are symbolically twins due to their simultaneous births at the beginning of the play, but they are also fundamentally different from each other in terms of class and culture. While Hébert complicates this binary by having both babies be gifted and cursed by the black and white fairies, and eventually showing that they are both equally trapped in a patriarchal world, the beginning of the play sets up the border as a crucial part of the setting and the development of the narrative. And indeed, Ludivine's life presents a series of negotiations; she must carefully balance on the fine line of being cursed or blessed. Whereas the black fairies bestow seven curses on her, echoing the magic number of the seven deadly sins, the seven white fairies attempt to provide Ludivine with blessings. As such, while Ludivine will marry a violent and awful husband, he will often be away from home and she will remain safe from his abuse. She will never be educated, "ignorante des livres et des grimoires," but she will be able to read "les signes dans le ciel et sur la neige, à l’heure où les ombres sont bleues" (Hébert

\footnotetext{
219 "Draws a white chalk line down the middle of the stage ... retrace the chalk line that she had previously drawn" (5, translated by Pamela Grant and Gregory J. Reid).

220 "Clearly mark out their territories ... all must remain clear: the new world is on the right, the old world on the left" (5, translated by Pamela Grant and Gregory J. Reid).
} 
25). ${ }^{221}$ This continuous balancing act is, in part, a comment on the ambivalent nature of borders.

John Crebessa and Ludivine Corriveau embody two opposing types of borders: Crebessa as the divide and Ludivine as the threshold. Drawing on the works of Gloria E. Anzaldúa concerning the notion of frontiers, Paola Zaccaria claims that the frontier is an ambiguous polysemic term: on the one hand, it refers to a great divide, an edge, a wall, a battle field ... on the other hand, it can also be a synonym for bridge, threshold, a tierra de medio, a land of incessant passages ... it can be carried on as an act of aggression, as appropriation, even as cannibalism, but it can also be a space where the encounter of languages and cultures takes place and shape. (Zaccaria 58)

Crebessa, a central figure in La cage who also appears in Hébert's novel Kamouraska, symbolizes British power and authority. In describing Crebessa's move from the Old World to the New, the narrator Babette recounts, "notre histoire n'est plus séparée en deux par une ligne médiane. L'ancien monde bascule au loin dans un glou-glou d'îles englouties, quelque part en Angleterre. Voici le nouveau monde partout sous nos pieds comme un tapis. John Crebessa vient de s'établir dans la seigneurie de Fossambault, non loin de Québec" (Hébert 37). ${ }^{222}$ Babette claims that there is no longer a median line between the Old and New Worlds; rather than having two distinct plot lines, they are

\footnotetext{
221 "Ignorant of books and scribblings ... the signs in the sky and the snow, when the shadows are blue" (12, translated by Pamela Grant and Gregory J. Reid).

222 "Our story is no longer divided in two by a meridian. The old world is swallowed far away in a gurgling of engulfed islands, somewhere in England. Here is the new world, everywhere beneath our feet like a carpet. John Crebessa has just settled in the Seigneury of Fossambault, not far from Quebec City" (18, translated by Pamela Grant and Gregory J. Reid).
} 
joined together on New World soil, with the arrival of the British in the New World representing the tentative erasure of the borders between the British and the French Canadians through new possibilities for assimilation. However, Crebessa's migration to Fossambault actually concretizes the border between these two worlds and evokes what Mary Louise Pratt calls the contact zone wherein "cultures meet, clash, and grapple with each other, often in contexts of highly asymmetrical relations of power" (6-7). Through his arrival in the New World, Crebessa becomes a physical obstacle, embodying half of the binary oppositions at play—Crebessa versus Ludivine, British versus French Canadian, man versus woman, law versus criminality, guilt versus innocence, as well as power versus powerlessness.

Crebessa's bordering gesture is a metaphoric act of aggression as it perpetuates a hierarchy between the British settlers and the French-Canadian habitants. When he hears the villagers praise La Corriveau for her kind heart and helpfulness, he asserts that "cette créature se mêle de ce qui ne la regarde pas. Moi seul, en ce pays, ai le pouvoir d'exaucer ou de débouter les gens" (Hébert 69). ${ }^{223} \mathrm{He}$ considers himself an all-powerful ruler or God, a notion that is constantly repeated throughout the play. He tells his wife when they marry, “j’affirmerai mes droits de maître et d'époux. ... Je proclamerai à nouveau ... mon pouvoir et ma puissance d'homme. Nul n'osera me contredire" (Hébert 36) ${ }^{224} \mathrm{He}$ also tells Ludivine that his "pouvoir est très grand" (Hébert 71) and that he is the voice of

\footnotetext{
223 "That woman is meddling in things that are none of her business. In this country, I alone have the power to grant appeals or reject petitions" (37, translated by Pamela Grant and Gregory J. Reid).

224 "I shall affirm my rights as master and husband. ... I will proclaim anew my power and strength as a man. No one will dare to contradict me" (18, translated by Pamela Grant and Gregory J. Reid).
} 
justice, echoing Tom Caribou's assertion that English justice is just. ${ }^{225}$ In other words, only he wields the power to control the fate of the villagers.

Crebessa's thirst for power begins in his early childhood. The black fairies call him "fils de notre coeur, ange noir prédestiné ... enfant surdoué pour le mal, fourbe, cruel, tourmentant père et mère, torturant bêtes à poil et à plumes" (Hébert 29-30). ${ }^{226}$ Before controlling the inhabitants of the New World, his power derived from his sense of control over Rosalinde. Rosalinde parallels Beaulieu's La Corriveau Blanche in that both are rather unimpressive characters playing minor roles in their respective plays. From the moment of her birth, Rosalinde is given all the opportunities that Ludivine is not; she is educated (but she cannot show it because of the black fairies' curse) and has all the riches she can possibly desire (though her husband will keep them away from her under lock and key) (Hébert 18-19). Like La Corriveau Blanche, she is submissive and subservient at the expense of her happiness even though she does not embody the traditional Québécois woman. Her only role, according to Crebessa, is to provide him with a male heir, and she is fated to do so since one of the black fairies declared that "pour le plaisir d'amour aussi il [ton mari] te privera et tu feras des enfants dans l'économie du bonheur la plus stricte" (Hébert 19). ${ }^{227}$ As such, Rosalinde's and Ludivine's roles intersect since they are both perceived as mere biological, reproductive instruments. Women are destined to be confined to the eponymous "cage" as a result of the systemic patriarchy

\footnotetext{
225 "Power is very great" (38, translated by Pamela Grant and Gregory J. Reid).

226 "Son of our hearts, predestined black angel ... child with such a gift for evil, treacherous and cruel, tormentor of your mother and father, torturer of furred and feathered creatures" (15, translated by Pamela Grant and Gregory J. Reid).

227 "Of the pleasures of love he will also deprive you, and you will conceive children in the most meagre allotment of happiness" (8, translated by Pamela Grant and Gregory J. Reid).
} 
that permeates various societies, from Québec to Britain. Even before Babette appears on stage in the play's prologue, two cages are veiled in the background of the stage: "la scène est nue et sombre. Au fond, à droite et à gauche, on devine les cages, enfouies sous des housses noires. Seul le devant de la scène est éclairé. Dans ce rayon lumineux apparaît Babette" (Hébert 11). ${ }^{228}$ This opening scene reveals that for the birth of every baby girl appears a cage ready to confine her.

Babette foreshadows in her opening monologue the moment of Rosalinde's confinement. When the latter marries Crebessa, she will become trapped in this "cage ordinaire, toute dorée, de celles qu'on offre habituellement aux femmes de qualité, le jour de leur mariage" (Hébert 12). ${ }^{229}$ The description corroborates the idea of marriage as confining women to a life of misery. Indeed, Crebessa is the only one responsible for Rosalinde's imprisonment. After entering the cage with Rosalinde for their nuptial celebrations, Crebessa subsequently exits and leaves Rosalinde locked inside. He shouts to his servants, "allez! Camouflez-moi tout ceci! Dissimulez bien le fer et les barreaux" (Hébert 37). ${ }^{230}$ He wants the cage to resemble "un joli manoir de pierres roses, avec fenêtres et portes fermées et marteau de cuivre sur la porte. Que seule la clef de fer demeure intacte, reconnaissable entre toutes, dans ma main” (Hébert 37). ${ }^{231}$ The pink stones codify this manor, revealing that it is made for a woman. Babette sees "le joli

\footnotetext{
228 "The stage is bare and dark. Upstage, right and left, cages draped in black covers can be made out. Only the front of the stage is lit. BABETTE appears in this circle of light" (3, translated by Pamela Grant and Gregory J. Reid).

229 "A customary cage, all in golden, such as is habitually offered to women of quality on their wedding days" (3, translated by Pamela Grant and Gregory J. Reid).

230 "Come! Hide all of this! Conceal the iron and bars as well" (18, translated by Pamela Grant and Gregory J. Reid).

231 "A pretty manor of pink stone ... with closed windows and doors, and a copper knocker on the door. Let only the iron key, in my hand, remain intact, distinct from all others" (18, translated by Pamela Grant and Gregory J. Reid).
} 
manoir de Rosalinde, là-bas, sur la colline" that "domine le pays" and is "charmant dans la lumière" (Hébert 38). ${ }^{232}$ The possessive suggests that the manor is a sign of Rosalinde's prestige and status, when in fact, it is a symbol of her confinement and Crebessa's dual domination over her and the land.

If, as Blodgett suggests, the permeability of a border is premised on the act of translation, then Crebessa symbolizes non-translation due to his desire to preserve the hierarchies that privilege men of his status. Instead of promoting an exchange, a zone of negotiation or contestation as Ludivine does, Crebessa silences intercultural and interlinguistic translations among the play's characters in order to preserve the hierarchies at play and to remain at the head of his family, the inhabitants of Canada, the law, and religion. He wishes to impose his authority and maintain his power over others. As Maureen O'Meara astutely indicates, Crebessa "personifies the evil that comes from accepting without question established authority that uses its power to either kill or subjugate others" (169). In this sense, he resembles Tom Caribou who attempts to maintain established authority without question by refuting Marie-Josette's and Zèbre's narratives. Crebessa uses his power to subjugate Ludivine. His sexual desire for her suggests a kind of fascination with the cultural other, and metaphorically reveals his desire to violate the borders separating him from Ludivine, as well as those between the English and the French Canadians. When he visits Ludivine, he asks her, "si je viens, la nuit, crier sous tes fenêtres : 'La Corriveau j'ai envie de toi', m'ouvriras-tu ta porte et me

\footnotetext{
232 "Rosalinde's pretty manor, over there, on the hill. ... dominates the countryside ... charming in the light" (19, translated by Pamela Grant and Gregory J. Reid).
} 
prendras-tu dans ton lit, comme un enfant malade?" (Hébert 71). ${ }^{233}$ This sexual desire recalls Zaccaria's idea that closed borders are an invitation to aggression. Echoing Beaulieu's use of the woman-as-nation trope, Hébert's Corriveau figure embodies the woman-as-nation model, but only because of the way Crebessa views her. Crebessa's carnal desire for Ludivine symbolically evokes Britain's metaphoric sexual and territorial conquest of New France as a form of control and dominance. Unable to achieve his sexual fantasy, he seeks to punish Ludivine by bringing her to court on charges of murder when, in fact, her husband's death was accidental. She explains that she was being a dutiful wife by strictly following her husband's orders to shoot anyone who approaches the house while he is away working in the woods. Consequently, upon her husband's unexpected return, Ludivine shoots and kills him. However, as she explains how the accident occurred, Crebessa interrupts her and claims that anything she says is irrelevant.

There is a strong hint that Ludivine is accused of murder and must go to trial, not for killing her husband, but because she refuses to give in to Crebessa's sexual demands. He calls upon the seven deadly sins—all personified characters in the play—-to testify against La Corriveau and prove how she is greedy, prideful, envious, gluttonous, and so on. After calling L'Orgueil, L'Envie, L'Avarice, and La Luxure to the stand, Crebessa exclaims, "Ludivine Corriveau! Je t'ai vue, de mes yeux, en l'absence de ton mari, forniquant avec un misérable barbouilleur de couleurs. Je t'ai vue, de mes yeux vue!"

\footnotetext{
233 "If I come around at night, calling for you under your window, 'La Corriveau, I want you!' will you open your door to me and take me into your bed, like a sick child?" (39, translated by Pamela Grant and Gregory J. Reid).
} 
(Hébert 97). ${ }^{234}$ While the personified sins accuse La Corriveau of misconduct, they actually corroborate Crebessa's hidden desires. According to Gregory J. Reid, “the play suggests that she [Ludivine] was brought to trial, in part, because she had earlier rebuffed Judge Crebessa's sexual advances ... We are made to understand that Ludivine is being put on trial because of her independence, her impervious bravery in rejecting the advances of the Judge" (133). Furthermore, Crebessa's aforementioned self-identification as "un enfant malade" when he beckoned Ludivine for sexual favours (Hébert 71), and especially his desire to be taken care of as a sick child, confirm Annabelle Rea's argument that Crebessa is "a male child ... endowed with keys, the keys to power ... [that] will later enable him to control many things" (28). In describing this character, Rea maintains that he evokes the notion of "cellule familiale" which simultaneously signifies "family unit" and "family cell," that is to say, a family prison (28). Crebessa is at the centre of this "cellule familiale" and, with his keys, is the only person to wield power in the familial prison.

However, there is some ambiguity about Crebessa's role. Arguably, within the family cell, he goes from representing a child to a father - the one who possesses authority and true power. Crebessa selectively chooses who has a voice and who does not, in order to prove his point and show that Ludivine is a threat to patriarchal figures. He silences all the characters who attempt to defend La Corriveau. For example, since La Paresse's testimony does not provide evidence of La Corriveau's guilt, Crebessa declares

\footnotetext{
234 'Ludivine Corriveau! I saw you with my own eyes, when your husband was away, fornicating with a miserable dabbler of paints. I saw you, with my very own eyes!" (54, translated by Pamela Grant and Gregory J. Reid). As a side note to the translation, the Deadly Sins L'Orgueil, L'Envie, L'Avarice, and La Luxure are called Pride, Envy, Greed, and Lust in Grant and Reid's translation.
} 
that “La Paresse n'a pas assez de cœur au ventre pour dire la vérité, elle rechigne devant l'effort, son témoignage ne peut être pris en compte. Nous nous en tiendrons donc aux autres témoignages, qui sont accablants" (Hébert 100). ${ }^{235}$ In doing so, Crebessa depicts Ludivine as a threat to her husband, whom she shoots - she is a murderess who holds no remorse for her husband. Furthermore, through her defiance, she is a threat to the Judge himself, a "father" of the law, and self-proclaimed "father" of the New World and its inhabitants. His call upon the seven deadly sins as the Crown's witnesses against La Corriveau also makes of Crebessa a metaphoric spokesperson for God and thus a religious father who holds in his hands the keys to heaven and hell.

Crebessa makes for an interesting paternal figure since he embodies two different types of paternity. Saint-Martin argues that generally speaking, "en littérature québécoise comme ailleurs, on relève tout d'abord de nombreux pères absents : pères inconnus, pères partis, pères peu attentifs" (18). ${ }^{236}$ She maintains that it is difficult to find the appropriate distance between father and child, resulting in the former being either too far or too close. With his two-year-old son, Crebessa is too far and is therefore an absent father figure. He sends his boy away to England for what he deems a proper education. In other words, Crebessa once again functions as a policer of borders by preventing his child from entering the border of the New World. In contrast, with Ludivine, Crebessa takes on a fatherly role, as father of the law, of religion, and of the land, that is too close. In the specific context of father-daughter relations, it is difficult to determine the adequate

\footnotetext{
235 "Sloth doesn't have enough fortitude to tell the truth. She is unwilling to make an effort and her testimony should not be taken into account. So we will restrict ourselves to the testimony of the other witnesses, which is overwhelming" (56, translated by Pamela Grant and Gregory J. Reid).

${ }^{236}$ In Québécois literature like elsewhere, we depend first and foremost on numerous absent fathers: fathers who are unknown, fathers who have left, fathers who are neglectful.
} 
familial proximity. As Saint-Martin notes, "la bonne distance psychique entre père et enfant semble presque impossible à trouver : entre le père absent—donc trop éloigné—et le père incestueux, donc trop proche, on trouve difficilement un moyen terme" (20). ${ }^{237}$ Crebessa's sexual desires for Ludivine therefore reveal a desire for incestuous proximity, an aggression that once again exemplifies a violation of the borders between self and other. This situation reverses the passages in Ma Corriveau wherein it is the daughter, Marie-Josette, who struggles with paternal/incestuous relationships with her father and husbands. Whereas La Corriveau Noire metamorphoses La Corriveau Blanche's desires for a loving father figure into incestuous, sexual fantasies, such fantasies are all contained within the male figure, here, and the violation of borders will never come to pass.

Opposing the definition of the term "border" as a divide, the definition of border as a bridge or threshold presents promising possibilities, as Blodgett, Zaccaria, and Simon respectively note. Ludivine certainly embodies what Blodgett considers the permeable zone of negotiation and site of discursive contestation. From the moment of her birth, she has embodied a zone of negotiation. She is forced to negotiate throughout her life since the fairies cursed and blessed her. For example, she is cursed to never have children of her own, but she becomes a mother figure to all those in need. Hébert thereby interprets her, or translates her, into a new mother figure that contrasts archetypal representations of the mother figure as "bad" or "castrating." Ludivine is not the archetypal monster-mother figure who stands in the way of her son's ambitions. Neither is she the absent mother, nor the mother figure that is central to the perpetuation of the

\footnotetext{
${ }^{237}$ The proper psychic distance between father and child seems almost impossible to determine: between the absent father - in other words, too distant — and the incestuous father, in other words, too close, it is difficult to find the middle ground.
} 
Québécois people, with her body serving as a reproductive instrument. In fact, when her husband, Elzéar, forces her to perform her conjugal duties, she cannot give him a child. Her "ventre ne produira pas de fruit ni [s] on sein de lait" because of a curse the black fairies place upon her (Hébert 22) ${ }^{238}$ Ludivine even dreams at some point that she surprises her husband with a particular kind of child—a baby with "une tête de mort" (54). ${ }^{239}$ O’Meara affirms that recognizing that Elzéar's power depends on his descendants continuing the race of patriarchal violence, she [Ludivine] acknowledges her refusal to perpetuate this family line. In a dream, she parallels the scene of his wedding gift of violence, using the same preliminaries of "j' arrive" and "[r]egarde ce que je t'apporte, mon mari" (54). Looking into the stroller, he finds a child who "a une tête de mort... [et qui] n’a jamais été vivant, ni conçu par moi, ni mûri dans un ventre maternel, ni expulsé dans les douleurs" ([Hébert] 64). (172-73) $)^{240}$

This dream about a dead child symbolizes Ludivine's defiance against her husband's abuse and a rupture in his genealogical line. Through her defiant dream, Ludivine demonstrates her unconscious desire to close the border, to end her husband's genealogical line and preserve her integrity. She dreams of controlling the border, not to egotistical ends like Crebessa, but in order to help her community; rather than being an oppressive father figure, she wishes to be a protective mother.

\footnotetext{
238 "Womb will produce no fruit, nor will [her] breasts, milk" (10, translated by Pamela Grant and Gregory J. Reid).

${ }^{239}$ Grant and Gregory translate this phrase as "that child that looks like death!" (29). The term "une tête de mort" refers to a skull. In French, it specifically refers to a symbol of a skull typically signifying something that is deathly or deadly.

240 "I am coming .... look what I have brought you, my husband ... looks like death! ... [and who] was never alive, was never conceived by me, never grew in a mother's womb, was never born in the throes of labour" (29, translated by Pamela Grant and Gregory J. Reid).
} 
By rejecting her maternal womb, Ludivine rejects her biological role. Instead, she is extremely caring and nurturing toward those in need — children who are abandoned at birth or handicapped, and the elderly who have nowhere to go. In this sense, "in his absence [Elzéar's], she [Ludivine] also transforms her desertion and her infertility into liberty, and goes about giving birth to a community of the marginalized that will become her family" (O’Meara 173). The members of Ludivine's reconstituted family work together at Ludivine's home as thanks for the woman's open arms and hospitality. Hébert therefore uses the figure of La Corriveau to reconfigure the traditional family structure found in the patriarchal Québécois society. This reconfiguration of the traditional family structure can be interpreted as a microcosm for the nation. Ludivine's approach to motherhood suggests a shift from family-based filiation, a structure premised on blood ties and biological succession, to community-based affiliation, which is premised on individuals bound non-biologically. Synthesizing Edward Said's interpretations of filiation and affiliation, Hussein A. Abdirahman claims that "unlike the 'failed idea' of filiation, which openly insisted on the unilinear, unicentric, dynastic authority of fatherhood (and, by extension, on the purity of a specific culture, the unity of a given tradition, the exclusive validity of monarchical rule, or the transcendent rule of a divine origin), affiliation at least in principle affirms an open, hybrid plurality” (169). Ludivine's family unit functions without the authority of fatherhood. It focuses on the social community, rather than the biological, and is centred around the female mother figure-Ludivine.

Ludivine's motherly role contrasts that of Rosalinde, which consists solely of providing the judge with a son who will subsequently be sent off for a proper British 
upbringing and education. Ludivine's role therefore defies Crebessa's attempt to maintain patriarchal structures of nationhood. Ludivine moves away from the individual to the communal, shown in the multiplicity of voices that speak in unison at the trial to defend Ludivine (what Hussein calls the "open, hybrid plurality"). Initially a victim of the British Conquest, La Corriveau is transformed by Hébert into a figure that emblematizes the collective Québécois identity. Her transformation can be interpreted as a form of translation since the act of translating is "an activity involving manipulation and rewriting, as political engagement ... language is revealed to be as much an instrument of power and action as of communication" (Claramonte 81). It is through language that Ludivine can refute Crebessa's sexual advances, refuse to bear her husband's child, and accept society’s rejections. Her various decisions and actions defy social norms. At Elzéar's and Crebessa's expenses, this transformation of roles gives power to Ludivine. In other words, Ludivine's rejection of traditionally accepted female stereotypes and her recreation of a new motherly role therefore upset the hierarchal dynamics at play by decentralizing Crebessa's paternal authority and replacing it with the maternal figure.

Ludivine's embodiment of altruistic and inclusive motherhood prevents the perpetuation of a retrograde patriarchal Québécois society and further provides a new model of nationhood, one that transcends cultural and gendered borders. McBride contends that while contemporary critics focus on the "English officials responsible for Marie-Josephte's trial, as well as those in charge of 'assimilating' French-Canadians" in twentieth-century literary works about La Corriveau, Hébert's "reconception of La Corriveau's myth actually places equal blame on both Crebessa and Elzéar, depicting both English and Québécois men as violent, manipulative oppressors of women” (139). 
This equal apportionment of blame to both English and Québécois men recalls Beaulieu's Tom Caribou, the Québécois man who fulfilled the role of the English judge in the reenactment of Marie-Josette's trial. Central to this comparison is Hébert's treatment of male and female characters in her play. Whereas Tom Caribou embodied British power and masculinity, contrasting the effeminate and devirilized Québécois men, Hébert refuses to equate masculinity with British culture and colonial power, and femininity with Québécois culture and colonial inferiority. Crebessa and Elzéar are equally powerful and patriarchal toward Ludivine. Presented neither as virile nor particularly feminine, the latter nevertheless triumphs over all male characters regardless of their cultural background or machismo. She is neither submissive nor frigid like La Corriveau Blanche. In fact, she is attracted to, and shows romantic interest in the painter Hyacinthe, who visits her from time to time while her husband is away in the woods. However, she is also devoid of La Corriveau Noire's sexual aggressiveness and chooses to remain faithful to Elzéar. The evening after a serious conversation with Hyacinthe wherein he asks her, “et si je te disais que je t'aime et que tu m'aimes?" (Hébert 84), she simply needs to be “dehors, seule, à l'air libre, en pleine campagne pour écouter [s]on coeur battre” $(85) .{ }^{241}$ Her instinct to contemplate her situation calmly and solitarily reveals self-reliance and independence, though one that is quite different from that of La Corriveau Noire. Although Ludivine remains faithful, she does not shy away from the notion of sex or perceive the body shamefully. When Crebessa accuses her of infidelity, she exclaims, "si vous voulez parler de ce que peuvent faire un homme et une femme ensemble, tout nus,

\footnotetext{
241 "And if I were to tell you that I love you and that you love me? ... outside, alone, in the fresh air, in the country, to listen to the beating of [her] heart" (47-48, translated by Pamela Grant and Gregory J. Reid).
} 
dans un lit, non, rien de semblable ne s'est jamais produit entre le peintre Hyacinthe et moi” (Hébert 102). ${ }^{242}$ Ludivine inhabits a world wherein power and strength are not determined by gender. The complexity Ludivine shows as a character and her exclusion from pre-established female allegories underscore Hébert's interruption of the one-to-one relation of the allegory, that is to say, the tendency of past (and most often male) writers to treat women as mere allegorical symbols.

In the introduction to this chapter, I noted the relevance of translation when contemplating the possibility of transcending borders. Ludivine's transformation into a benevolent mother figure in her community reveals that she is a "translatable figure" in that she becomes "a tool for the powerful and the disempowered" (Cortés and Harding 1), transcends cultural and gendered borders, and opens up the discourse for negotiation and understanding. Although a translatable figure such as Ludivine can seem rather ideal and largely positive, the very nature of the figure's translatability is complex and challenging. Translation "cannot be merely taken ... as a means of access to other cultures; it cannot be considered a reliable reflection. ... They [cultural translations] are part of the process of producing, not innocently reproducing, meaning" (Blodgett, "Is a History of the Literatures of Canada Possible?" 10). As in any case of exchange, translation comes at a price; there is some loss of meaning. With respect to the notion of loss, Blodgett asserts that translation "has a curious way of thematizing loss, which is part of the price of any moment of origin" ("Is a History of the Literatures of Canada Possible?" 10). In Canadian literatures, this loss is often associated with death or sacrifice. Such death or

\footnotetext{
242 "If you are referring to what a man and woman may do when they are naked in bed, no, nothing of that sort ever happened between the painter Hyacinthe and myself" (57, translated by Pamela Grant and Gregory J. Reid).
} 
sacrifice does not signify an absolute end, but rather acts as a rite of passage that produces another transitory moment in a series of negotiations (Blodgett, "Is a History of the Literatures of Canada Possible?" 10). The thematization of loss is manifested in Crebessa's death. After announcing Ludivine's fate in court, that she "sera exposée dans une cage de fer jusqu'à ce qu'un oiseau noir ait ses prunelles au bec," Crebessa is agitated and "porte sa main à sa poitrine" (Hébert 107). ${ }^{243}$ Afterward, when Hyacinthe tries to defend Ludivine, Crebessa is angered to the point of "s'affaisse[r] dans son fauteuil," and then dies suddenly from a mysterious coronary problem (Hébert 110). ${ }^{244}$ His death symbolizes the demise of the Old World and patriarchy. Yet, representative of the thematization of loss, it can also be seen as a gain because it symbolizes the rite of passage for other characters in La cage, allowing them to move forward and triumph at the end of the play.

The cross is a recurring symbol of sacrifice and loss intrinsically connected to rites of passage (Blodgett, "Is a History of the Literatures of Canada Possible?" 11), but the metaphoric cross in Hébert's work is not hung. Numerous adaptations of the legend of La Corriveau recount Marie-Josephte's hanging in a gibbet placed at a crossroads in Lévis. Much like the eponymous protagonist in Laure Conan's Angélique de Montbrun (1882), she "is burdened with becoming one of the frequently recurring signs of French Canada's being possessed by dispossession" (Blodgett, "Is a History of the Literatures of Canada Possible?" 11). Whereas Rosalinde is destined to be imprisoned in her golden cage when she marries at the age of fifteen, in accordance with the legend of $\mathrm{La}$

\footnotetext{
243 "Will be displayed in the iron cage until a black bird has her eyeballs in its beak. ... places his hand on his chest" (60, translated by Pamela Grant and Gregory J. Reid).

244 "Slump[ing] down in his chair" (61, translated by Pamela Grant and Gregory J. Reid).
} 
Corriveau, Ludivine's imprisonment is predestined to occur during her execution. Despite the foreshadowing of Ludivine's sacrifice when Gaston, Elzéar's brother-in-law, evokes the image of a cross as he comments on the fact that Ludivine is "maigrichonne comme un christ sur la croix" (Hébert 48), it is Crebessa's death that replaces that of Ludivine. ${ }^{245}$ Consequently, La Corriveau's gibbet is not suspended; Ludivine is neither metaphorically nor literally sacrificed, nor is she used as her father's scapegoat, as was the case in the historical record (Lacourcière 21; Ferland and Corriveau 121), but symbolically resurrected through Hébert's rewriting of the myth. Ludivine's father even accepts responsibility for his daughter's unhappy marriage. He admits to Crebessa, “vous voulez savoir la vérité, M. le juge? Je vas vous la dire, moé, la vérité. Pus de patates, pus de cochon, pus de force, pus d'espérance. Alors on a marié Ludivine avec Elzéar" (Hébert 104). ${ }^{246}$ Through the father's honesty and Ludivine's survival, Hébert subverts the story of La Corriveau by ironically associating Ludivine's escape from the gibbet to the rite of passage that allows her to transform into a new Corriveau figure. Reid notes that "the crucial irony in Hébert's play is the death of John Crebessa. This reversal is abrupt, unexpected, and contrary to established narratives surrounding the trial of la Corriveau" (135). Against all expectations, Ludivine successfully escapes her predetermined destiny, saves society's ex-centric individuals, and goes on to rescue Rosalinde, her symbolic twin who is still confined within a patriarchal world, at the end of the play. In discussing feminist revisions of Québécois theatre and québécité, Erin Hurley argues that

\footnotetext{
245 "As scrawny as a christ on the cross" (25, translated by Pamela Grant and Gregory J. Reid).

246 "You wanna know the truth, Your Honour? I'll tell ya the truth, straight. No more potatoes, no more pigs, no more strength, no more hope. So we married Ludivine off to Elzéar" (58, translated by Pamela Grant and Gregory J. Reid).
} 
women — in their diversity and concrete reality — take the stage. It is not merely that they speak their own words and manifest their own images instead of someone else's, though this too is important; it is also that the words they speak, the situations they describe, and the roles they enact are not given to be interpreted as representative of something else. (182)

Whereas Rosalinde speaks few words and manifests the image Crebessa has of her, Ludivine enacts the role of adoptive mother she understands as meaningful to her community, protects her adopted children by killing Elzéar, and remains truthful in court despite potentially losing the court trial and consequently her life. In the last scene, the protagonist and other benevolent characters succeed because they work together; the quest for national liberation in Beaulieu's play fails, in part, because La Corriveau Blanche and La Corriveau Noire refuse to cooperate with each other, but here Ludivine departs to free her English counterpart as soon as she can. Unlike Beaulieu's radical, nationalist revolution, Hébert ends her work with a kind of radical optimism that places a feminist, affiliative community at the centre of national reconciliation.

In conclusion, since its appearance in de Gaspé's Les anciens Canadiens, the legend of La Corriveau has undergone a series of negotiations at the hands of French- and English-Canadian writers who have tried to appropriate the legend and integrate it to French-Canadian (and later Québécois) nationalist projects, or even to an anglophone, pan-Canadian project. As seen in Chapter Two, de Gaspé's and Kirby’s respective Corriveau figures were gothic figures of otherness whose deaths symbolize the metaphoric death of the French Canadians, and whose impending assimilation to the British population would represent the homogenization of the other in the construction of 
a pan-Canadian project. Almost one century later, literary works such as Beaulieu's $M a$ Corriveau and Hébert's La cage would refute such projections of La Corriveau's role as a victim of British power and authority. In contrast to La Corriveau Blanche, who accepts her position as a "victim" or dutiful assimilator to British power and authority, La Corriveau Noire rejects this position. Beaulieu instrumentalizes the female body and uses La Corriveau Noire's sexual fantasies to express desires for the Québécois nation to break free from its colonial condition. In many ways, La Corriveau Noire reclaims her position of alterity and wholly symbolizes the rejection of British power, but to modify McBride's article title, she transforms "from vilified to vixen," and consequently cannot transcend the cultural, linguistic, and gendered borders that founded the power dynamics of the legend of La Corriveau. ${ }^{247}$ Rosalinde, as a woman subjected to her British husband's power and authority, is relegated to a similar position as that of La Corriveau Blanche. However, Rosalinde does not function in opposition to Ludivine; indeed, their duality serves to show the similar conditions of women, regardless of their culture, class, and language. Ludivine, like La Corriveau Noire, stands for a nationally liberated Québec. However, unlike Beaulieu's character, she does not attempt to reverse the hierarchy of colonial power, but transcends such hierarchies. She subverts the "bad" or "castrating" mother archetype, transforming the mother figure (via the figure of La Corriveau) into a nurturing being that encourages bonds of affiliation rather than filiation without imposing a specific vision of the Québécois nation. Hébert's Corriveau figure loses her association with the guilty, evil witch, successfully metamorphosing, as

\footnotetext{
${ }^{247}$ McBride's article is titled 'From Vilified to Victorious: Reconceiving La Corriveau in Anne Hébert's La Cage."
} 
McBride claims, from vilified to victorious. Blodgett rightfully asserts that when discussing a subject that is capable of translation, its translatability makes it difficult to arrive at a conclusion concerning its significance since such significance is also transitory and continuously crossing borders. As we will see in Chapter Four, La Corriveau continues to be transitory and transformative as the legend extends beyond Québécois literary borders and is repurposed in the hands of English Canadians such as Glover, Americans such as Lessard, and Franco-Ontarians like Ménard. 


\section{Chapter 4: The Legend of La Corriveau Beyond Québec}

Many literary works reinventing the legend of La Corriveau were being produced in French Québec in the post-1960s period, but the same cannot be said about the anglophone literary sphere. Prior to the publication of Glover's short story "La Corriveau" in 1993, anglophone literature only reproduced existing versions of $\mathrm{La}$ Corriveau. Some of these revivals were an outgrowth of the English-Canadian antimodernist movement that was popular in the 1920s and 1930s. This movement encouraged a return to "the simple life" and led to a revival of folk legends in literature (Belshaw, Canadian History: Post-Confederation). John Douglas Belshaw asserts that antimodernists "romanticized their own histories" (Canadian History: PostConfederation). He writes, "in Nova Scotia, an entire tourist industry was built up around the notion of Nova Scotians as a simpler folk engaged more in the production of handicrafts and folktales than industrial goods, a people whose lives had seemingly escaped the touch of modernity" (Belshaw, Canadian History: Post-Confederation). Whereas some antimodernists looked toward Indigenous peoples to find the simple life, others saw this simplicity in the lifestyle of French Canadians. Katherine Hale's "La Corriveau" in Legends of the St. Lawrence (1926) and Hazel Boswell's "The Island of Orleans" in French Canada: Pictures and Stories (1938) reproduce de Gaspé's version of the legend with slight variations, even as Hale echoes Kirby's Corriveau figure by characterizing La Corriveau as a poisoner. In the introduction to her collection of legends, Hale describes the tradition of French-Canadian songs and how they "have become Canadianized through the generations" (3). One can infer from this comment that Legends of the St. Lawrence similarly hopes to "Canadianize" French-Canadian folklore 
so that they may "still [be] enjoyed and still cherished" within English Canada (Hale 3).

Dirk Gringhuis's “The Witch's Cage" in Were-Wolves and Will-O-The-Wisps:

French Tales of Mackinac Retold (1959) and Joan B. Thornton McLeod's "La Corriveau \& the Blond" (1975) are translated excerpts of de Gaspé's Les anciens Canadiens and modified excerpts of Kirby's The Golden Dog respectively. Arguably, Gringhuis's collection of French stories and songs is an attempt to bolster American culture and substantiate the history of the Mackinac State Historic Parks, Michigan, to attract tourists. After a brief description relating to the history of French families in Mackinac, the backcover text of Gringhuis's collection reads: "these traditional tales, which originated in eastern Canada or even France, were often given a local setting to make them more humorous or frightening. ... In order to preserve this rich French heritage which has made such an impact on the Straits of Mackinac we are here presenting some typical tales and songs translated from the French" (Gringhuis). In a desire to preserve French heritage, it is logical that Gringhuis would draw on de Gaspé's interpretation of La Corriveau rather than reinvent the legend himself. McLeod transforms the sections from The Golden Dog involving La Corriveau into verse. This Anglo-Québécois text was published by a short-lived publishing operation called Bonsecours Editions. Meanwhile, Mary Alice Downie's "La Corriveau" in The Witch of the North: Folk Tales of French Canada (1975), published by Oberon (a small publishing press in Ottawa, ON), duplicates the legend of La Corriveau using excerpts from Les anciens Canadiens. Altogether, it is evident that these anglophone writers do not radically alter the legend of La Corriveau as it was represented in the nineteenth century. While Québécois writers were creating a politicized image of La Corriveau reflecting new feminist and nationalist 
trends, these anglophone writers were antiquarianizing La Corriveau, attempting to

preserve a longstanding figure from French-Canadian folklore in an idiom that was quite far removed from the figure's function within Québec.

The aforementioned anglophone texts were devoid of explicit nationalist biases. Indeed, at the time of Downie's publication, French-Canadian material was largely absent from English-Canadian anthologies and "Canadian" anthologies altogether. Robert Lecker argues that "in this way, Canadian literature anthologies gradually erase Quebec and construct a representative of Canada that is purely English" (260). Moreover, "the desire to isolate English-Canadian literature is also an act of territorial aggression that is terminological in force" (Lecker 263). At the same time, the blooming interest in "ethnic" writing suggestively correlates with a decreased emphasis on French-Canadian folklore such as the legend of La Corriveau. ${ }^{248}$ While there was a general turn away from FrenchCanadian folklore outside of Québec with respect to nation-building appropriation especially, writers at times returned to the legend of La Corriveau when they had a personal interest in the subject.

This chapter focuses on three non-Québécois writers and their respective explorations of the legend: English-Canadian writer and Governor-General Award

\footnotetext{
${ }^{248}$ Looking at the historical context of ethnic studies in Canadian literature, Blodgett's Configuration: Essays on the Canadian Literatures (1982) foregrounded comparative literature with emphasis on immigrant and ethnic minority writing. His "attention to the subject of ethnicity and to non-anglophone and non-francophone writing was a new perspective in Canadian literature at the time, and broadened its scope" (Verduyn 125). Scholars such as Joseph Pivato recognized Blodgett's work as setting the stage for a new critical field of study in Canadian literature. Another seminal text is Gary Caldwell's Les études éthniques au Québec : bilan et perspectives (1983). In Québec, terms for ethnic writing have come up, such as écriture pluriethnique, immigrante, minoritaire, mineure, transculturelle, métisse, migrante, écriture néoquébécoise, and écriture nomade (Verduyn 129). As Christl Verduyn notes, "of these different phrases, écriture migrante - evoking issues of exile and othering while circumventing categorisation by ethnic origin - has had the most staying power in Quebec. Its translation - 'migrant writing' - has not had similar success in English Canada, where the concept of diasporic writing emerged to usage in the new millennium" (129-30).
} 
winner, Douglas Glover; Gene Lessard, American retiree who previously worked in forest entomology and took up writing as a hobby; and Franco-Ontarian writer and poet, David Ménard. Glover's interest in the legend of La Corriveau possibly comes from his more general interest in English- and French-Canadian relations and historical narratives. Lessard's interest in the legend of La Corriveau derives from his claimed genealogical connection to Marie-Josephte Corriveau. Finally, in an interview for Bible urbaine, Ménard explains that he first encountered the legend of La Corriveau as a teenager. He watched the television film Ma Corrivaux (1995) featuring Anne Dorval on RadioCanada and since then, has been fascinated by the legend. Of course, I acknowledge that these three authors come from significantly different backgrounds. My decision to group these three authors together in this chapter is not intended to obscure their differing cultural histories and contexts of production, but rather to show how regardless of their divergent circumstances, they all denationalize La Corriveau.

Whereas Chapter Two demonstrated how the figure of La Corriveau was a threatening, gothicized other and Chapter Three demonstrated how it was translated into an other imbued with Québécois nationalist and feminist symbolism, Chapter Four examines La Corriveau as a non-threatening other in texts that dissipate or complicate the figure's nationalist functions. Its focus is on how these three non-Québécois writers' contrasting techniques of inscribing La Corriveau into non-Québécois spaces and contexts result in a denationalizing of the figure. The adaptations of the legend of $\mathrm{La}$ Corriveau by Glover, Lessard, and Ménard, I suggest, all exploit the figure's ambivalent semiotic field—not as an exercise in national myth-making (as seen with de Gaspé, Kirby, Beaulieu, and Hébert)—but as a means of exploring their own ambivalences 
toward nation, history, and religion respectively. To address these themes, this chapter draws on a variety of theoretical frameworks. Similar to the previous chapter, the section on Glover focuses on representations of nationhood and feminism, as well as their entwinement in the nation-as-woman trope. Lessard's section draws on a different set of theories related to life writing as a genre and mode of fiction. Finally, Ménard's section is informed by the history and conventions of Franco-Ontarian poetry and the francophone conte, as well as Ivone Gebara's studies on the intersection between theology and feminism.

Glover's rhetorically complex short story "La Corriveau” (1993) reveals the challenges related to transposing folklore into a different context, especially as it reverses the folkloric legend, presenting the figure of La Corriveau as an English-Canadian woman subduing a francophone Québécois man. ${ }^{249}$ In other words, Glover's allegorical use of the legend tacitly reproduces English Canada's domination over Québec despite his attempt to use La Corriveau as a satirical figure to critique English Canada in his short story. In contrast, Lessard's self-published novel An Object of Conviction: A Compelling Story of a Conquered People, Social Injustice and Family Tragedy (2016) moves away considerably from nationalist projects. This novel can be seen as a work of speculative life writing wherein Lessard attempts to understand his genealogy and reinvents his family's past. Finally, Ménard's francophone poetry collection Poupée de rouille (2018) thematically removes the sociopolitical context surrounding the legend of La Corriveau,

\footnotetext{
${ }^{249}$ Glover's “La Corriveau” was first published in the literary magazine Descant in 1993. Subsequently, the short story was republished in the short story collections 16 Categories of Desire (2000) and Bad News of the Heart (2003). The short story was translated into French by Daniel Poliquin and published by L'instant même in a collection of short stories called Meurtres à Québec (1993). It was also translated into French by Micheline Lanctôt in Seize sortes de désir, published by Boréal in 2004.
} 
instead offering an interpretation of the legend that reflects his own spirituality and focuses on a love story wherein a woman sacrifices herself to save her insane husband. Ménard's denationalization of the legend of La Corriveau envisages the contemporary trend toward post-nationalist sensibilities. These more recent adaptations of the legend of La Corriveau are often unwittingly reactionary in the way that they disrupt or ignore Québécois counternarratives that present the figure of La Corriveau as serving Québec's nationalist project by rebelling against Quebec's colonial condition (as seen in Beaulieu's play) or by establishing a new positivistic Québécois society (as seen in Hébert's play).

\subsection{Satire and Subversion in "La Corriveau"}

Glover's flagrantly revisionist short story opens with an anglophone Torontonian woman visiting Québec City for a weekend to enjoy the annual Winter Carnival. She wakes up beside a dead Québécois man resembling Mick Jagger, with a headache and no recollection of the previous night. Before examining the story's complex play with gender, folklore, and national identity, it is important to note that by setting "La Corriveau” during the Québec Winter Carnival, Glover highlights a pre-existing conjunction between the legend and the festival that hints at La Corriveau's ambiguous history as a national symbol within Québec. The Québec Winter Carnival has been celebrated intermittently since 1894 and became an annual tradition as of 1955, when the “première édition du Carnaval de Québec contemporain” was presented (Provencher 117). ${ }^{250}$ This inaugural edition marks the "création de l'effigie," and the "Bonhomme Carnaval fait son apparition, entouré de reines; celle qui vendra le plus de billets sera

\footnotetext{
${ }^{250}$ First edition of the contemporary Québec Carnival.
} 
proclamée reine du Carnaval" (Provencher 117). ${ }^{251}$ In 1955, under the theme of "Canadian legends," the organizing committee of the Québec Winter Carnival submitted the idea of an ice sculpture in the shape of La Corriveau's cage that would be built in front of the city hall in Québec City. Met with vehement reactions from the general population due to the macabre nature of La Corriveau's legend, the idea was quickly dropped (Ferland and Corriveau 253). In 1971, there was a renewed interest in Québec's folkloric Corriveau figure, but the idea was once again rejected (Ferland and Corriveau 264). The theme in 1971 was "Le Bonhomme rêve en couleur," which potentially alludes to the fact that this was to be the first televised edition of the Carnival. According to Jean Provencher, "en direct du Grand Théâtre, qui ouvre ses portes, on télédiffuse pour la première fois l'élection et le couronnement de la reine" (118). ${ }^{252}$ Glover's choice of the winter carnival setting therefore brings together Québécois folklore that is well-known in Québec City and its surrounding regions, and a popular tourist attraction that promotes Québécois culture and functions as "une locomotive de la vie hivernale québécoise" (“À propos du Carnaval"). ${ }^{253}$ This choice also calls to attention the ambiguous reception of the legend of La Corriveau and foregrounds the instability that makes this figure appear more available to appropriation and reversal.

As the use of Québécois setting and folklore suggests, "La Corriveau" is one of Glover's many works that thematizes "the Canadian landscape — and indeed what it is to be Canadian" (Stone 13), touching "specifically on the relationship between English-

\footnotetext{
${ }^{251}$ Creation of the mascot. ... Bonhomme Carnaval makes his first appearance, surrounded by queens; the woman who sells the most tickets will be proclaimed the Queen of the Carnival.

${ }^{252}$ Live from the inauguration of the Grand Théatre, the election and coronation of the Carnaval queen are televised for the first time.

${ }^{253}$ A locomotive of Québécois winter life.
} 
speaking and French-speaking Canada" (Marchand 130). Indeed, as a Canadian expatriate living in the United States since the early 1990s, Glover frequently explores Canadian identity in his fiction. "La Corriveau," in particular, emerges out of an era of instability between English Canada and Québec. Looking at the preceding decade, one can see how the years leading up to the short story's publication were shaken by several pivotal moments in English-French relations: the 1980 Québec Referendum, the Meech Lake Accord in 1987, and the Charlottetown Agreement in 1992. The female protagonist, who is also the story's narrator, mentions how she fears "the constitutional implications" of her actions (Glover, "La Corriveau" 12), but overall, it is unreasonable to associate the action and symbolism of "La Corriveau" with a single event. The story's transformation of La Corriveau into an English-Canadian woman and the changes it initiates to La Corriveau's sociopolitical functions by moving the figure from a Québécois to an English-Canadian cultural context point to Glover's interest in developing a broader satire of English Canada's national myths about Québec. Analyzing the various layers of complexity in Glover's short story, I argue that Glover creates an intricate narrative that examines, satirizes, and complicates the discourse of English-Canadian and Québécois tensions, even as it subtly reaffirms this discourse's gendered presuppositions. In the analysis that follows, I focus first on the story's satire of English Canada's various strategies for ignoring, assimilating, and managing Québec's place within the national metanarrative of a unified Canada. Subsequently, I show how such a project is compromised by the semantic structure of Glover's satire - a structure that depends for its critique on the very gendered metaphors it seems, through its reversals, to overturn. If, like Glover's protagonist, English Canadians are trapped in an amnesic and 
myopic state, blind to the complexity of the cultural and political issues faced by the Québécois people because they are more familiar with stereotypical representations of the Québécois as they appear in English-Canadian historical narratives and records, then the short story's most interventionist gesture is to invite readers to rethink the national narrative of English Canada. This is a topic that Glover explores explicitly in his collection of essays Notes Home from a Prodigal Son (1999), where he describes at length his perception of English-Canadian and Québécois relations and suggests that the former has skewed opinions of the latter. For instance, in discussing Aquin and his works, Glover explains how "labelling French-Canadian thinkers like Aquin as mere separatists is a favourite gambit of Anglo-Canadians who want to pigeonhole and dismiss ideas that might prove more difficult to address than periodic Gallic discontent (much like a male chauvinist dealing with pre-menstrual syndrome)" ("Difficulty and Revolution" 57). ${ }^{254}$ In the same essay, he claims that "in the world-game of ideological catch-up, Quebec now stands one step behind what we might call the cutting edge of thought ..., English-Canada, two steps" (Glover, "Difficulty and Revolution" 58). These observations make clear Glover's own stance on the issue: that English Canadians are quick to dismiss the Québécois despite the legitimacy of the latter's ideas and social values.

Glover's interest in these issues of historical and cultural misrecognition derive in part from his desire for national renewal that would "create authenticity" to avoid the

\footnotetext{
${ }^{254}$ Although Notes Home from a Prodigal Son was published in 1999, the dates of publication for Glover's respective essays are listed beside the titles in the collection. "Difficulty and Revolution" was first published in 1991. "The Sparks That Fly Off When Two Skins Touch" and "The Familiar Dead" were published in 1994 and 1995 respectively.
} 
constant feeling of being inauthentic. In an interview, he explains that one sure way to make yourself feel inauthentic is to tell yourself that everything you have done in the past, every memory you have, your whole history, is wrong. Thus in my work, I try to reflate the romance of the noble savage, which at its base is an image of the human capacity to fall in love, to allow oneself to be recreated by the Other. (Glover, "The Sparks That Fly" 145)

In other words, for Glover, "truth is always other (or the Other)" ("The Familiar Dead" 166). This truth, as well as Glover's longing to be "recreated by the Other" is embodied in his Corriveau character, the English-speaking Torontonian protagonist of his short story. Through "La Corriveau," Glover suggests that Canada fails as a nation insofar as English Canada has been unable to put itself in the shoes of the marginalized Québécois. His vision of national renewal therefore involves English Canadians inhabiting the position of the Québécois other in similar ways to how his protagonist inhabits La Corriveau's position in order to form critical understandings of the other.

Because the relationship between Québec and English Canada has for so long been characterized by metaphors of marriage and divorce, Glover's critique of EnglishCanadian myopia begins by rewriting the gendered hierarchies and meanings that underpin that discourse. His protagonist thus subverts the fixed image of La Corriveau that dominated Québécois representations of the figure between 1763 and 1990: female, francophone, and French-Canadian, set in opposition to an other that is male, anglophone, and English. Although Glover's protagonist is unnamed and therefore never called La Corriveau, the title of the short story and the unfolding of narrative events clearly establish the protagonist as a significantly adapted iteration of the legendary murderess. 
In Glover's revisionist national allegory, the female Corriveau figure symbolizes English Canada whereas the victim symbolizes Québec. When the protagonist contemplates the dead man next to her at the beginning of the narrative, she assumes that "he must be French" and that she, "being English-speaking and from Toronto[,] ... can see the headlines: ANGLO TOURIST SLAYS INNOCENT QUÉBECOIS FAMILY MAN IN FATAL SEX ORGY" (Glover, "La Corriveau" 13). One major effect of this parodic transformation of the Corriveau figure from a Québécoise to an English-Canadian woman is a transfer of La Corriveau's nineteenth-century gothic association with murder and evil to English Canada. Whereas the theatre of nationalist Québec had transvalued La Corriveau's gothic otherness into a symbol for anti-colonial resistance, Glover simply assigns La Corriveau's earlier witch-like figuration to the nationalist version's oppressors.

The satirical implications of this reversal and moral transfer are reinforced and elaborated by the overlapping ways in which Glover links his English-Canadian Corriveau — in spite of her female sex — to the masculine gender position that traditionally characterizes English power in the traditional marriage metaphors between English Canada and its Québécois "bride" that the story mocks. It does so in two interlocking ways: first through its masculinization of the protagonist's gender performance, and second through its presentation of her dominating attitudes and behaviour, each of which works in concert to condemn her (and thus also English Canada's) actions and attitudes in the eyes of the reader. When the protagonist describes her womanly body, detailing that her breasts are "tiny" and that "androgynous is one word for [her] chest" (Glover, "La Corriveau" 12), for instance, she queers conventional images of femininity. She also 
characterizes her ankles as "unfeminine tree trunks" (Glover, "La Corriveau" 13). These descriptions suggest that the protagonist does not manifest the physical beauty standards associated with the Québec/English Canada marriage metaphor's heteronormative, Western femininity. The protagonist knows that she is not conventionally beautiful as she continuously complains about her unattractive body.

With respect to non-physical characteristics, the protagonist also breaks away from long-established stereotypical conventions of femininity: she is neither nurturing nor loving, as evidenced by her flat, unsympathetic reaction to Robert's death; she is free in her sexuality, as epitomized in her one-night stand with Robert and her casual "twelveyear affair with an already-attached CBC radio producer" (Glover, "La Corriveau" 15); and she does not identify with wifely or motherly duties since she remains an unmarried and childless woman. Taken as a whole, the protagonist's gender performance and physical attributes differentiate her from the marriage metaphor's accommodating "feminine" position.

This flouting of conventional femininity even seems to imply a second-order gender reversal - that is, a reversion back to the very "masculine" position of the EnglishCanadian husband in the marriage metaphor that the story, at the most obvious level, inverts. In other words, the "unfeminine" protagonist behaves as though she is the domineering English-Canadian husband present in the popular national allegories of Québec-Canada relations. For instance, she seeks to enact a dominating, violent masculinity through her relationships with Robert and the police detective named Gilbert. Such desire is based on the logics of Western discourses of heterosexuality and romantic love, which dictate that the views of the "dominant" heterosexual male are privileged 
over those of the "subordinate" female (Monckton Smith 1). While the protagonist is not in a romantic relationship with either character in the strict sense of the term, she nevertheless assumes the function of the dominant heterosexual male when she pursues a one-night stand with Robert, and another potentially illicit romance with Gilbert. She dominates the narrative since the dead Robert cannot speak for himself, and she constantly steers Gilbert's conversations back to her own interests. More importantly, the protagonist could be said to assert her dominance and perform masculinity by killing Robert. It is certainly noteworthy that she stabs Robert with her Swiss Army knife, for the knife can be seen as a phallic symbol that penetrates the victim's body, and it is closer to the conventional "[male] use of force" and "weapons" than the stereotypical female use of "poison, drugs, or suffocation" (Vronsky 43) — methods that various oral adaptations of the legend describe La Corriveau as using. The protagonist's criminal act thereby strikingly suggests English Canada's desires to exert some sort of heteronormative masculine control over Québec in an only partially gender-swapped reversal of the conventional metaphor of a marriage between nations.

In making English Canada an androgynous female, one that continuously rejects feminine traits in favour of masculine ones, Glover parodies the contradictions particular to Canada's internal and international identity: its desire to appear strong, masculine, and dominant, especially toward Québec, while simultaneously reckoning with its status as "the defenceless maiden to the American hulk" and other national superpowers (Probyn 80). Canada's supposed position as feminine and as dominated translates to its inability to establish full dominance over Québec. In this sense, Canada is constrained to a "dominated-dominant" position as it is "ni totalement [dominé], ni totalement 
[dominant]" (Boltanski 244). ${ }^{255}$ The protagonist humorously depicts this confusion between being dominated and dominant, much like Beaulieu's Ti-Oui who emulates Lemuel Gulliver's dominated and dominant position. She conflates her allegorical English-Canadian self with the Québécois minority when she exclaims, "we are people of extremes, a nation within a nation" (Glover, "La Corriveau" 15). Her assertion likens English Canadians to the Québécois, who sometimes see themselves as being a nation within a nation, and who are at times symbolically relegated to a dominated position too. Just as La Corriveau is "the Siren of Québec" that "call[s] the men of the city to their deaths" (Glover, "La Corriveau" 17), embodied in the protagonist "who travels around preying on French-Canadian calèche drivers named Robert" (19), Canada metaphorically preys on Québec to give itself the appearance of power.

Robert's gender is also strategically perverted by Glover in a complex way. On the one hand, although he serves as an allegory for Québec, he is obviously inconsistent with the image of the Québécois wife. The protagonist repeats the terms "man" and "handsome" six times in the first two pages, drawing attention to Robert's gender. She also likens Robert to Mick Jagger, "the man of [her] dreams" (Glover, "La Corriveau" 11), multiple times throughout the narrative. Yet, this emphasis on Robert's manhood ironically highlights his emasculation. Pondering men like Robert, the protagonist muses that "often they may have seemed dead. You know—limp, moribund" (Glover, "La Corriveau" 11). The juxtaposition of the words "dead," "limp," and "moribund" conflates notions of vitality and virility. Just as a penis can be limp and moribund - in other words, lifeless-Robert's corpse is lifeless and limp, emasculated by the very fact of his death,

255 "Neither wholly dominated nor wholly dominant" (134, translated by Graham Burchell). 
and signifies his obvious inability to take any sort of action. His emasculation acquires added significance in the context of his allegorical function and Québec's self-perceived colonization during the sixties. As discussed in Chapter Three, colonized subjects were portrayed as conventionally feminine in order to underscore their inferiority. Roberts argues that "the colonization process can clearly be seen as one of 'devirilization,' emasculation and reduction to the status of women (metaphorical femininity). Therefore, the movement towards decolonization involves the desire for full masculinity and the concomitant destruction of one's femininity" (Roberts 20). Diane Lamoureux similarly claims that "when the emphasis is put on oppression, it is either gendered as female or an emasculated male" (199). As such, although Robert does not epitomize the image of the Québécois wife, his emasculation nevertheless situates him in a position of marginalization, subordination, and weakness vis-à-vis Canada. Robert lacks what Vacante calls the "manly power" necessary to escape his codified position as an emasculated man, especially since "the fullest expression of strong manhood would only come after the attainment of complete independence for the province of Québec" ("Quebec Manhood" 32). His emasculation suggests that regardless of the gendered image used to portray Québec (the wife or the emasculated man), the province remains in a subordinate position with respect to Canada. Thus, Glover scathingly satirizes the way Canada maintains its dominance by displacing its femininity onto Québec, a displacement that is evoked in the combination of Robert's emasculation and the protagonist's androgyny as she metaphorically transfers her femininity onto Robert.

In addition to satirizing the gendered power dynamics at play in nationalist metanarratives about Canada and Québec, Glover employs his Anglo version of La 
Corriveau to satirize English Canadians' myopia regarding Québécois issues. This aspect of the satire proceeds by reinventing Québécois nationalist evocations of La Corriveau's imprisonment as a metaphor for English-Canadian ideological constraint. The protagonist's reflections on memory and language issues, for instance, reveal important similarities to those of her Québécois counterparts: from the mid-1970s onward, there was "une volonté grandissante de ... faire sortir [La Corriveau] de sa cage" (Ferland and Corriveau 264) and explore the "dimensions émancipatrices et libératrices" (257) of this character in Québécois literature. ${ }^{256}$ Glover's protagonist follows in, but transforms the significance of, this tradition. Throughout the short story, the protagonist has recurring headaches, which she describes as "a virtual blazing light of pain, as though [her] skull were caught in the bars of a cage" (Glover, "La Corriveau" 20). These headaches can be read as a form of mental confinement, a symbol of English Canada's imprisoning myopia in regard to the major issues of the Québécois minority. Glover wishes to release La Corriveau and English Canadians from their myopic cages and explore the emancipatory and liberatory possibilities that would ensue from this endeavour.

Given Glover's original formula for realizing this scenario in "The Sparks That Fly"-re-creation through the other—releasing English Canadians from cultural myopia might be expected to take the form of a sincere identification with "La Corriveau." In the satirical mode of his short story, however, such identification is always only partial or compromised—its self-mockery not so much revelatory as unwitting. After claiming that she is part of "a nation within a nation, without language or identity" (Glover, "La

\footnotetext{
${ }^{256}$ A growing desire to release [La Corriveau] from her cage. ... emancipatory and liberatory dimensions.
} 
Corriveau" 15), the protagonist reproduces the main tenets of Québécois nationalist discourse in her own self-accountancy when talking to Gilbert. She "tell[s] him of [her] memory lapses (a common Anglo-Canadian complaint), [her] language problems, [her] blackouts and [her] inability to find a publisher for [her] poetry" (Glover, "La Corriveau" 19). Such parodic appropriations are a far cry from Glover's utopian vision of "recreation through the other"; indeed, the protagonist's longing to inhabit and become the other due to her sense of alienation from the Canadian nation places her in a state of reverse mimicry. In a postcolonial context, mimicry refers to the process whereby a colonial subject mimics aspects of the colonizer such as the latter's language or culture, with the unspoken proviso that the colonial subject can only become "almost the same, but not quite" (Bhabha 86, italics in original). According to Bhabha, this ambivalence disrupts the relationship between the colonized and the colonizer, undermining the authority of the latter. Considering Québec's self-perception as a colonized nation, mimicry would entail a Québécois imitating an English Canadian; as an English Canadian desiring to mimic the colonized other, however, Glover's protagonist performs reverse mimicry and as a result, ironizes and subverts English Canada's own colonial authority over Québec, "mock[ing] and undermin[ing] the ongoing pretensions of colonialism and empire" (Huddart 39). The protagonist's satirical role, in other words, transforms mimicry into self-mockery, and thereby mocks and undermines English Canada's myopia during her reflections on Québécois issues.

This dynamic is further foregrounded through the theme of cultural amnesia and forgetting, whereby the protagonist's memory lapses and blackouts take on a special meaning within the context of English-Canadian nation-making that further undermines 
her ostensible identification with the Québécois other. The protagonist translates the Québécois motto je me souviens as "I remember myself" (Glover, "La Corriveau” 14) and maintains, "I myself remember nothing" (17). Her numerous references to the words on the Québécois licence plate evince the intrinsic relationship that exists between memory and Québécois identity. Jocelyn Létourneau describes this relationship as follows: "il est, semble-t-il, un impossible oubli dans la mémoire collective des Québécois, et c'est celui d'avoir été les victimes de l'autre. Ne pas admettre et assumer ce fait ... c'est provoquer consciemment, dans le corps du sujet collectif, cette terrible maladie ... soit l'amnésie aliénante et négatrice de soi, c'est-à-dire le refus de se reconnaître et de se le dire tel que l'on fut, tel que l'on est" (20-21). ${ }^{257}$ Létourneau's statement plainly evokes Québec's nationalist sentiment, especially since the expression je me souviens "a été amenée ou exploitée dans les débats publics au Québec par un grand nombre d'intervenants soucieux de rappeler aux amnésiques présumés leur 'devoir de mémoire"" as a means of resisting the erasure of Québécois history and culture (30). ${ }^{258}$ The motto readily "répond aux défaites (plaines d'Abraham de 1759) et échecs (rébellions des patriotes de 1837)" and "ainsi, en tant que devise de ralliement identitaire pour la communauté francophone et catholique, elle prend en fait un sens revanchard et nostalgique" (Moser 296). ${ }^{259}$ The Québécois expression raises questions about whose

\footnotetext{
257 "It seems there is one thing that is impossible for Quebecers to forget, and that is their having been the victims of the other. Not to acknowledge and deal with this fact ... is to knowingly provoke in the body of the collective subject that terrible disease ... an alienating, self-negating amnesia, a refusal to recognize oneself and speak oneself as one was, as one is" (8-9, translated by Phyllis Aronoff and Howard Scott).

258 "Is often exploited in public debate in Quebec by those anxious to remind supposed amnesiacs of their 'duty of memory"' (18, translated by Phyllis Aronoff and Howard Scott).

${ }^{259}$ Corresponds to the defeats (the Plains of Abraham in 1759) and failures (The Rebellion of 1837) ... thus, as an identity-rallying motto for the francophone and Catholic community, it takes on a spiteful and nostalgic tone.
} 
culture one is remembering, dovetailing with “one of [Glover's] major themes- the instability of memory, with the attendant possibility that faulty memory arises from past events too painful to recall" (Marchand 132). ${ }^{260}$

In contrast, the opposite of memory - amnesia - may serve as a mechanism "that obscures the often violent creation of nation-states" (Goldman, Rewriting Apocalypse 26). Renan makes a similar claim when he states, "l'oubli, et je dirai même l'erreur historique, sont un facteur essentiel de la formation d'une nation" (7). ${ }^{261}$ The protagonist's memory lapses, blackouts, and overall amnesiac state satirically expose just such a process of forgetting: the desire to erase the past and the injustices English Canada committed against other peoples. If she and the rest of English Canada are so willing to forget the violent creation of nation-states of which Goldman speaks, then 'l'amnésie libératrice consiste moins à taire, à négliger, à répudier ou à effacer ce qui fut qu'à désactiver le mal (ou les germes de nocivités) de manière à amnistier l'ayant-été, à se dégager de ses fureurs indélébiles et à libérer l'avenir de ce qui pourrait l'empêcher d'éclore sous la forme d'un 'renouveau"' (Létourneau 28). ${ }^{262}$ Tellingly, the protagonist's liberating amnesia allows her to forget Robert's murder and thereby explore Québec City as she pleases for the remainder of her trip. As Philip Marchand points out, in contrast to

\footnotetext{
${ }^{260}$ Smaro Kamboureli complicates the general interpretation of je me souviens by highlighting the ambiguity of the subject "je." The subject "could be every citizen of Québec: francophone, anglophone, or allophone; Québec-born or diasporic subjects; perhaps even First Nations people in Québec” (Kamboureli, "The Diaspora Writes Back" 27). She nuances her claim with the word "perhaps," arguing that the "sovereignty politics in this Canadian province" would not enthusiastically include immigrants or Indigenous peoples in the collectivity of Québécois citizens (Kamboureli, "The Diaspora Writes Back" 2728). Kamboureli thus points out the necessity of considering whose history is being remembered.

261 "Forgetting, I would even go so far as to say historical error, is a crucial factor in the creation of a nation" (11, translated by Martin Thom).

262 The liberating amnesia consists less in ignoring, repudiating, or erasing what has been than in deactivating the bad (or the seeds of harm) so as to grant amnesty to what has been, liberate oneself from one's enduring furies, and free the future from what could prevent it from blossoming in a 'renewal", (16, translated by Phyllis Aronoff and Howard Scott).
} 
the Québécois licence plate, "the motto on the licence plate of Ontario, Yours to Discover, is truly postmodernist, implying that English Canada can be constructed any number of ways, precisely because it has no identity to remember.... In the context of the English-French allegory, if you will, it means that English Canada cannot be troubled to remember much of its own past" (132). These words echo Glover's own assertion that "Anglo Canadians go around with the haunting idea that they have forgotten who they are," whereas "French Canadians are obsessed with the idea of not forgetting who they are" ("The Sparks That Fly" 143). In contrast to the Québécois people who need to remember in their quest for sovereignty, English Canadians need to forget and have, to a certain extent, the "luxury" of forgetting because Canada is already a nation-state.

Glover depicts the protagonist's memory lapse during her tour of Québec City as a form of willful suppression in which "movement seems imperative to ward off the flood of memories which just might possibly prove unpleasant if not actually inculpatory" (Glover, "La Corriveau" 16). She admits: "my constant reference to loss of memory in the foregoing is clearly a case of reaction formation; we all try to put our worst crimes in the best light possible" (Glover, "La Corriveau" 21), an indication that she knowingly conceals the crime she committed for the sake of her reputation. Her liberating amnesia therefore conceals her guilty past. The protagonist uses her amnesic state as an excuse to avoid being arrested for murder — a figuration of English Canada's national amnesia. The protagonist's preference for movement over static reflection on her murderous actions allegorically signifies that "English Canada has not yet been able to go through the process of recognizing the oppression of the Québécois — and other francophones—and undertak[e] a resolute effort to make amends" (Conway 8). John Frederick Conway 
argues that while English Canada has acknowledged and made amends for the oppression of Indigenous peoples and the internment of Japanese-Canadians during World War II-a highly debatable claim - it needs to undergo a similar process with French Canadians for the sake of Canada's survival (8-9). Interestingly, Conway's Debts to Pay: English Canada and Québec from the Conquest to the Referendum (1992) and Glover's "La Corriveau" neatly complement each other. At the end of "La Corriveau," the protagonist confesses to all of her crimes and the sins she committed in her life, including killing Robert. She announces in the last lines of the narrative, "this time I'll get off, I say. You'll see. I do not think he hears me" (Glover, "La Corriveau" 22). The fact that Gilbert, the Québécois, does not hear her suggests that her confession is insufficient. Gilbert's deafness captures Conway's dubiousness about English Canada's attempts at making amends to Québec; as Conway maintains (at least up until the publication of his monograph), "the Québécois nation does not believe we have yet paid our debts. Nor do many of us" (222).

The protagonist's culturally and nationally symbolic amnesia is tellingly accompanied by her "language problems." Recalling and opposing the Québécois Corriveau figures who could not understand the events of the trials as they occurred in English, Glover's protagonist cannot fully enjoy her trip because she does not understand French. When she buys newspapers, she notes that they are "in French—unreadable" (Glover, "La Corriveau" 15). Although this comment appears benign and even natural coming from a tourist, the protagonist's inability to read French speaks to a larger English-Canadian sensibility_or insensibility_regarding the importance of the French language and its relationship to Québécois memory, nationalism, and identity. The 
French language is intrinsically linked to the French-Canadian past. It has been a critical part of the Québécois identity and upheld as something to preserve during the rise of Québécois nationalism. Emerging out of the Quiet Revolution was “a new Québécois identity—centred on territory and language rather than on religion and ethnicity" (Mills 19). The first time the term "language" appears in "La Corriveau," it is placed in conjunction with identity, "a nation within a nation, without language or identity," underlining the symbiotic relationship between these elements. Dale Thomson corroborates Mills's assertion when he writes, "by the early 1970s, the French language had clearly replaced the Catholic religion as the primary symbol for Quebec society" and was a means of "strengthen[ing] the francophone community's identity" (75). Language erects a barrier between the English-Canadian and Québécois nations, but can also be a means of building identity.

Paralleling her opposition to the Québécois citizen whose duty is to remember his or her cultural past, the protagonist is also structurally opposed within the story to the Québécois writer since she is a poet unable to use language to confront her own history. Michel Biron et al. assert that from the 1960s onward, “l'écrivain [québécois] n'entend plus s'occuper seulement de littérature. Il assume désormais une fonction politique” (363). ${ }^{263}$ The Québécois writer "s'empare de la langue non pas à la façon virtuose, mais plutôt au nom d'une liberté d'expression qu'il ne sait d'ailleurs trop comment assumer. L'écrivain se joue de la langue pour plonger dans sa propre histoire, son passé, sa mémoire, et pour habiter pleinement les lieux qu'il fréquente désormais" (Biron et al.

\footnotetext{
${ }^{263}$ A [Québécois] writer is not only responsible for literature. Henceforth, he or she takes on a political role.
} 
364). ${ }^{264}$ However, even as language provided some freedom of expression, it was also a "symptôme et cicatrice" for members of the political and cultural magazine founded in 1963 called Parti pris, and other writers who understood Québec to be in an oppressed and colonized state (Gauvin 321, italics in original). ${ }^{265}$ Writers for Parti pris “décriv[ai]ent leur propre étrangeté dans la langue" and their sense of alienation resulting from language (Gauvin 321-22). ${ }^{266}$ Gaston Miron, one of the writers for Parti pris, discusses this very alienation in his poetry collection L'homme rapaillé (1970). In “Monologues de l'aliénation délirante," the speaker feels “dépoétisé dans ma langue et mon appartenance / déphasé et déconcentré dans ma coïncidence” in the midst of the anglophone Sainte-Catherine Street in Montreal (Miron 27-28). ${ }^{267}$ The poet struggles in a state of self-alienation as a result of his language; he is dispossessed, transfixed because he does not know where he stands in relation to those who do not speak the same language - that is to say, a Québécois French. The French language, a distinctive feature of Québec, thereby relegates the Québécois to a position of otherness with respect to the rest of Canada since "la langue est étroitement associée au sentiment d'aliénation à la fois individuelle et collective" (Biron et al. 363), and with respect to France and the normative standards that l'Académie française imposes on the French language. ${ }^{268}$ While language alienates Miron's poet from himself, it is also through language that he can reclaim and embrace his identity and culture. In "Recours didactique," the poet uses language to

\footnotetext{
264 The writer seizes language not in a virtuosic way, but rather in the name of a freedom of expression that he or she does not quite know how to exercise. The writer transcends language to dive into his or her own history, past, and memory, as well as to inhabit fully the places to which he or she now has access.

${ }^{265}$ Symptom and scar.

${ }^{266}$ Described their strangeness toward their language.

${ }^{267}$ De-poeticized in my language and my belonging / Out of step and unfocused in my coincidence.

${ }^{268}$ Language is narrowly associated with feelings of individual and collective alienation.
} 
involve himself in the political sphere. He claims that while he was a poet with a face like any other, he now recognizes Québec's state of inferiority and must use his role as a poet to enter the public sphere. He decries that all poets must use their poetry, written in the French language, as a political tool to change Québec's condition. Miron's poetry thus inherently engages with Québécois nationalism and identity in a way that Glover's protagonist cannot grasp due to her English-Canadian perspective.

La Corriveau's only veritable contact with the French language is through written expression, as she insinuates that Robert spoke English with a French accent (Glover, "La Corriveau" 12) and mentions that Gilbert interrogates her in English (19). Her inability to read French symbolizes her inability to discern the strong connection between the French language and Québécois identity. More importantly, the protagonist is unable to achieve a sense of wholeness with her own language or motherland, something that Glover satirically signals by having her outrageously appropriate the Québécois poet's language struggle for English Canada. The themes of writing, poetry, and language interweave in the narrative via the protagonist's unsuccessful attempt at being a poet, one who has "given everything for [her] art" (Glover, "La Corriveau" 15) but has a "dismal poetry career" (15) and cannot "find a publisher for [her] poetry" (19). The story implies that her failure as a poet directly stems from her amnesia; she cannot use language to dive into "sa propre histoire, son passé, sa mémoire,” to use Biron et al.'s words. Unlike Québécois writers and their "poetic” Québécois province (Glover, "La Corriveau” 18), the protagonist cannot channel her individual or collective history creatively in order to forge a sense of identity and belonging. Daniel Francis explains that "because we lack a common religion, language or ethnicity, because we are spread out so sparsely across 
such a huge piece of real estate, Canadians depend on this habit of 'consensual hallucination' more than any other people" (10). He asserts that accordingly, history becomes key to Canada's unity: "this is one function of history, to provide a rationale for the civic ideology. History explains where our institutions and values came from. Out of this shared experience of the past is supposed to emerge a 'national identity' which unites all Canadians and makes us unique" (Francis 10-11). The protagonist's memory lapses and blackouts prevent her from drawing on a longstanding English-Canadian history to write truly meaningful poetry from which could emerge a self-critical and potentially transformed "authentic" (to use Glover's term) national identity, or at the very least an understanding of her own identity. Her amnesia manifests itself as a "full-blown dissociative split, a form of fugue-state psychosis" (Stone 21) that reflects the impossibility of a unified, monolithic Canada since it, too, is "split." The protagonist's amnesia and "dismal poetry career" consequently cause her to feel alienated from Canada, which she compares to Mars and calls her "home and alien land" (Glover, "La Corriveau" 16).

The protagonist's imaginative engagements with the early history of New France hint at the possibility of genuine revelation and transformation, but ultimately are as damning as her attempts at poetry. After purchasing newspapers (a form of historical record) that she cannot read due to the language, she falls into a fantasy wherein she recreates imaginary dialogues between Samuel de Champlain and his wife Hélène Boullé. Whereas Samuel de Champlain is an iconic name and history books detail his achievements, the protagonist is more interested in the lesser-known Hélène Boullé. Explaining how Hélène came to the New World and returned to France shortly thereafter 
because she was unhappy, and how she joined a convent after her husband died, the protagonist thinks to herself, "this is a sad little story which reminds me of my own. Like Hélène Boullé, I have had a difficult time adjusting to life in Canada, though, unlike her, I have nowhere else to go" (Glover, "La Corriveau" 14). The unnamed protagonist is able to empathize with Hélène because of their shared marginalized position as women, and this empathy reveals a longing to connect more genuinely with the position of the other. Even though the protagonist is English-Canadian, she admits that, like the Québécois (or simply the French in Hélène's case), she feels alienated from her home (Glover, "La Corriveau" 14,16$)$.

Indeed, by recounting the narrative of Québec City's founder, the "father of New France" (Legaré 1), and Hélène, the protagonist hopes to assert the notion that "history is a male lie" (Glover, "La Corriveau" 16), and thus allegorically approaches Glover's own critical position on English-Canadian cultural myopia and its mystification of national history. Yet, even though she provides a feminist perspective on Hélène Boullé's biography, the protagonist inevitably and ironically provides a "history of the victors" when, as an English Canadian, she recounts the foundational history of French Canada. Conway notes that "English Canadians, searching for positive, upbeat themes and justifications, prefer versions of history that ignore or diminish the oppression of the Québécois. Undeniably negative events ... are overlooked or attributed either to the actions of defective individuals who happened to hold power at the time or to the temper of the times" (288). More importantly, he argues that "as victor, English Canada wrote the official history, selected the national symbols and controlled myths, rituals and rites of official national self-celebration" (Conway 288). Glover's culturally disjunctive 
anglophone Corriveau figure exemplifies this control of myth, using Québécois history and folklore to create her own private, fictional history of Québec. Her mediation of the brochure information echoes English Canada's attempt at creating a longstanding history for itself using French-Canadian stories. She manipulates symbolic figures such as Samuel de Champlain and alters pivotal points in French-Canadian history. Similar to Kirby and Le Moine, the protagonist is an English-Canadian writer who uses FrenchCanadian history and folklore as sources of inspiration while ironically revealing the subjectivity of her historical account. By the end of "La Corriveau," the protagonist's accounts of French-Canadian folklore and Hélène Boullé's story are forgotten, soon to be replaced with newspapers headlining the protagonist as a murderess, as well as Gilbert's official and authoritative account of the murder. Her account of history becomes meaningless as she is unable to write her own history.

In connecting the protagonist directly to the legend of La Corriveau, and indirectly to some of the first writers that gave prominence to the legend, Glover establishing a cyclical return to the first monstrous representations of the folkloric woman and embeds the protagonist's narrative in the literary tradition of female monster figures. Glover's androgenized, English-Canadian Corriveau figure bridges two manifestations of monstrosity. The first manifestation of monstrosity relates to Jonathan Kertzer's concept of the Canadian nation as monster. Kertzer argues that Canada's pursuit of national identity becomes a way of excluding ethnic, feminist, and Indigenous writers who do not share in the vision of national identity from which they are othered. Although he examines the tradition of literary history and the formation of English Canada's literary canon, his concept of nation-as-monster can be interpreted more broadly: the obsession 
with a national identity is a dream shared by the dominant white English-Canadian culture, but a monstrous obsession that is imposed on marginalized and minority groups. Moreover, inherent to this nation-building project is a patriarchal dimension. Kertzer writes that "the monstrous nation is redefined as patriarchy" and the "male-dominated society ... 'the engulfing monster"” (125). In "La Corriveau," the protagonist embodies the national, patriarchal monster that proves fatal to Robert, the symbol of a marginalized and minoritized Québec. She is no longer a falsely accused Québécoise, but a guilty, murdering, and aggressing English Canadian. Through her role, the protagonist therefore sheds light on how marginalized and minority groups may rightfully perceive Canada as monstrous. She feigns innocence when in reality, she is a monster that closely resembles her nineteenth-century counterparts.

Accordingly, Glover's rewriting of the Corriveau figure reveals a second manifestation of monstrosity: the protagonist's embodiment of the female monster figure akin to the earlier legendary depictions of La Corriveau. Glover's protagonist grotesquely appropriates the feminism and heroism relating to Québec's late-twentieth-century versions of La Corriveau and thereby travesties the legendary figure's fundamental sociopolitical functions. The protagonist has no need to resist patriarchy; Robert and Gilbert strikingly depart from the usual male characters presented in the Corriveau narratives, namely the domestically abusive and alcoholic husbands, the arrogant and cowardly father, as well as the powerful English judge. In fact, the protagonist sees Robert as a pathetic inconvenience. She muses over his death, which she originally believes may have been caused by a heart attack (a result of their love-making) or from an allergic reaction to shellfish before noticing the Swiss Army knife handle protruding 
from his ribs (Glover, "La Corriveau" 13). Speaking of his death, she says, "I am extremely irritated with Robert for inflicting his personal problems on me like this, first thing in the morning before my shower and a cup of coffee" (Glover, "La Corriveau" 13). Robert's death does not even deserve her sympathy or compassion, especially because it ruins her vacation plans. Similarly, Gilbert is a nuisance who "irritatingly ... keeps trying to steer the conversation back to Robert" (Glover, "La Corriveau" 19) and his words are "reductive and unpoetical" (18). The protagonist does not believe these men are worth any consideration, nor does she see them as oppressive or dangerous. On the contrary, the protagonist $i s$ the dangerous aggressor. Furthermore, she even expresses a form of misplaced and self-serving feminism as a result of her silence and oppression. The protagonist exploits an image of victimhood, presenting herself as naïve, confused, emotional, and innocent, as a ruse to lure unsuspecting and dutiful men such as Gilbert into her deathtrap. Ángeles de la Concha explains that "many latter-day [post-1980s] feminists have expressed a concern on the risks of vulnerability becoming associated with helplessness and victimhood, thereby fostering stereotyping, increasing powerlessness, and paternalistic and coercive forms of intervention" (84). By acting as a teary victim who "break[s] down and weep[s]" (Glover, "La Corriveau" 19), the protagonist perpetuates the problematic association of victimhood with feminism. However, this adverse perpetuation is deliberate and beneficial for the protagonist; she wants Gilbert's sympathy and paternalistic intervention, to use de la Concha's words, so that she may seduce and (if her history with Robert is to repeat itself) kill him.

Along with her rejection of traditional feminism, which contrasts with Québécois writers' portrayal of La Corriveau as a feminist symbol, the protagonist also transforms 
her anti-colonial symbolism to become a counter-symbol for English-Canadian heritage. She "realize[s] suddenly that [her] infatuation with Mick Jagger is merely an extension of English Canada's pernicious Anglophilia—substitute the Queen for Mick and [she is] like anyone else from Saskatoon or Victoria" (Glover, "La Corriveau" 20). ${ }^{269}$ The protagonist's comparison of Mick Jagger to the Queen is therefore suggestive of a strong sense of Anglophilia. Jagger is, of course, the lead singer of The Rolling Stones, an English rock band that was part of the "British Invasion." Complementing the movement's conspicuous label as a "British Invasion," the protagonist's impulse to call Robert and Gilbert by the name of Mick suggests a desire or tendency to invade Québec and assimilate metaphorically these Québécois men to English-Canadian culture and, by extension, its British ancestry. Glover's Corriveau figure thereby contrasts with the Québécois nationalist Corriveau in that she cannot, nor does she want to, ward off the British conquerors.

For all its satiric force, however, Glover's conversion of the figure of La Corriveau into an English Canadian remains troublingly incongruous insofar as it still culturally appropriates French-Canadian folklore; his Corriveau figure loses a specific history of resistance when transposed to an English-Canadian context and is re-assigned to the allegorical, albeit satirical, role of a self-justifying Canada. Just as Glover appropriates the figure of La Corriveau for satire, so too does he recreate the gender hierarchy of the marriage metaphor even as he tries to critique it. His gender binary reversal correlates with Elaine Pigeon's concern about the instability of gender and

\footnotetext{
${ }^{269}$ In discussing Jagger, Neil Nehring similarly associates the singer with the Queen, stating that "given such a lengthy career, the group's [Rolling Stones's] history inevitably includes highly contradictory phases, with singer Mick Jagger having mutated from revolutionary into royalty” (221).
} 
heterosexuality. Drawing on Probyn, Pigeon argues that "the shifting power relations between various nations or 'imagined communities' that give rise to the figuring of gendered positions illustrate how heterosexual binary categories are not stable, since the dominant masculine position can collapse into the feminine, while the feminine can assume a masculine position of dominance" (36). Accordingly, she suggests that these gendered positions confirm a heterosexist bias that privileges the heterosexual male in national discourses (Pigeon 36). The protagonist's androgyny and Robert's emasculation effectively blur the boundaries of gendered, heteronormative images of nationhood, but notwithstanding the instability and collapse of such, Glover's allegories of domination and submission still epitomize the privileging of the heteronormative male and thus continue to participate in the narrative of English Canada's dominance over Québec.

Much like his protagonist, then, and perhaps just as unintentionally, Glover participates in controlling representations of Québécois myths. "La Corriveau" is an ambitious literary critique of cultural appropriation accomplished through the very appropriation of a key Québécois legend for an English-Canadian context. The complexity of the story's satire allows Glover to challenge cultural representations of nationhood and the problems they engender, while simultaneously invigorating and perpetuating such problems. He primarily employs La Corriveau as a mirror reflecting English Canada's attitudes and misconceptions with regard to Québec, but in doing so, he divests La Corriveau of her former symbolic status within Québec's nationalist project. Just like Marie-Josephte Corriveau, Glover's protagonist is afflicted by the linguistic and cultural tensions dividing the francophone province and the Canadian nation. Her sense of alienation, failure as a poet, and rootedness in English-Canadian culture reflect English 
Canada's futile yet ongoing effort to appropriate French-Canadian and Québécois folklore and authenticate their own history and culture, to claim Québécois ghosts—and witches - and have them brandish the maple leaf flag. And yet, Glover successfully presents the figure of La Corriveau as a proud brandisher of the Canadian flag. His adaptation of the legend subverts national allegories and sets the stage for a forthcoming twenty-first century Corriveau that will acquire new sociopolitical functions as it is further disarticulated from its Québécois nationalist and feminist associations.

\subsection{Reconstructing the Corriveau Genealogy in An Object of Conviction}

Appearing twenty-three years after Glover's “La Corriveau," Lessard's An Object of Conviction (2016) is thus far the only anglophone written adaptation of the legend of La Corriveau in the twenty-first century. Set many years after Marie-Joseph has died and at a time when her daughter Angelique is a grown woman, the novel begins with Father Thomas Blondeau, who comes to pay his respects at the funeral of Angelique's grandfather, Joseph Corriveau. ${ }^{270}$ The unveiling of La Corriveau's story occurs through Angelique and Father Thomas's recollection of events. Father Thomas recounts the story of Joseph's and Marie-Joseph's incarceration to Angelique, and together, they piece these memories into a narrative that explains Louis Dodier's murder, Joseph's desire to protect his daughter, and Marie-Joseph's sentencing to death in a gibbet. This plot structure, as we will see in Chapter Six, echoes that of the film Nouvelle-France (2004) wherein Curé Blondeau, on his deathbed, recounts the events to La Corriveau's daughter France.

\footnotetext{
${ }^{270}$ In Lessard's novel, the name Marie-Joseph is spelled without the 'te' at the end.
} 
As this brief synopsis suggests, Lessard, like Glover, is interested in history. Whereas Glover uses the legend of La Corriveau to allegorize national politics and debates, Lessard is drawn to the figure out of an interest in his own provenance. Born in 1943, Lessard is an American with a BSc in Forestry and an MSc in Forest Entomology. After working various jobs, mainly in forestry, he retired in 2000 and has published two works via Createspace Independent Publishing Platform, Amazon's self-publishing service: Grandfather's Tale: The Story of Human Evolution and Dispersal (2012) and An Object of Conviction: A Compelling Story of a Conquered People, Social Injustice, and Family Tragedy (2016) (“Gene Lessard”). His reasons for writing and publishing these two works come from a desire to understand his origins. The Grandfather's Tale emerged out of Lessard's curiosity about human history:

my $10^{\text {th }}$ great grand father [sic] was a Native American and born in what is now Ontario, Canada in about 1595. He was a scout and interpreter for Samuel Champlain [sic]. His daughter was the $1^{\text {st }}$ Native American to marry a Frenchman in Canada. I wanted to know where his ancestors came from and how they ended up in Canada. ("Ask the Author: Gene Lessard")

Similarly, in discussing his most recent work, An Object of Conviction, he explains how he sought to write "stories about [his] ancestors in French Canada. [He] ha[s] a great grand mother [sic] that was hanged and gibeted [sic] in Quebec called La Correveau [sic]" ("Ask the Author: Gene Lessard"). In his acknowledgements, he mentions that he even visited Québec City to learn more about the legend of La Corriveau, conducted archival research, and interviewed descendants of Marie-Josephte Corriveau. Although An Object of Conviction is classified as a novel, it can be more accurately interpreted as a 
work of fictionalized life writing — one that reprises the genealogical approach of JosephEugène Corriveau (discussed in Chapter Three), who was tired of having a tainted patronym and began conducting archival research on Marie-Josephte Corriveau in the 1940s in hope of clearing his family name of murder.

As a genre, life writing inevitably works the boundary between fact and fiction. Is a work of life writing purely non-fiction? Or is all life writing, to some extent, fictionalized because writing one's experiences is a mediated and interpretative act? How does one take into account the accuracy of remembering? ${ }^{271}$ This ambiguity led many theoreticians and historians in the 1970 s to consider autobiography, biography, biofiction, biografiction, autobiografiction, and other related subgenres under the umbrella term of life fiction (Leader 1). Zachary Leader argues that "the blurring of distinctions may help to account for life-writing's growing acceptance as a field of academic study, reflecting a wider distrust of fixed forms, simple or single truths or meanings, narrative transparency, objectivity, 'literature' as opposed to writing" (1-2). The distrust of fixed forms and of single truths of which he speaks evokes a postmodern impulse, so it is not surprising that "auto/biografiction can be understood as a strand of what Linda Hutcheon defines as 'historiographic metafiction"” (Saunders 21). Max Saunders, for instance, sees in fictional life writing Hutcheon's description of historiographic metafiction as “intensely self-reflexive and yet paradoxically also lay[ing] claim to historical events and

\footnotetext{
${ }^{271}$ Michael Lackey recapitulates such debates in "Locating and Defining the Bio in Biofiction" (2016), citing works such as Carl Bode's “The Buxom Biographies" (1955) and Paul Murray Kendall's Art of Biography (1967). Marlene Kadar also discusses these debates in her introduction to Essays on Life Writing: From Genre to Critical Practice (1992). In addition to Kadar's edited collection of essays, see Zachary Leader's On Life-Writing (2015) and Paul John Eakin's Writing Life Writing: Narrative, History, Autobiography (2020) for further readings on contemporary approaches to life writing.
} 
personages" (Hutcheon, A Poetics of Postmodernism 5). ${ }^{272}$ Much like Glover's short story, then, Lessard's work opens onto the dilemmas of postmodern aesthetics, albeit unintentionally, and in a less self-consciously problematized way. Indeed, the tone of his work and his account of its production are marked by a very un-postmodern sincerity. His process does not involve self-reflexivity in Hutcheon's sense of "art that is selfconsciously art (or artifice)" (The Canadian Postmodern 1), but rather an inventive grappling with family narratives in ways that imaginatively negotiate the terms by which an infamous murderess like La Corriveau might be rewritten as a heroic ancestor.

Given Lessard's ancestral identification with La Corriveau, his novel, like the research of Joseph-Eugène Corriveau, becomes a means of engaging and narrating family history. Family narratives, a term sometimes used interchangeably with genealogy, family history, and biography (Langellier and Peterson 57), can contribute to shaping an individual's identity. Jody Koenig Kellas argues that "storytelling not only helps us make sense of family experiences, but also performs, creates, and shapes family relationships as well as individual and cultural identities" ("Framing Family: An Introduction" 3). She further asserts that "family stories affect and reflect family culture by communicating who a family is - its norms, its values, its goals, its identity" (Koenig Kellas, "Family Ties" 366, italics in original). Although Koenig Kellas examines family narratives through daily conversations among family members, her logic arguably extends to other types of family narratives such as Lessard's fictional biography; An Object of Conviction is a space wherein Lessard can creatively imagine and write about family relations, and

\footnotetext{
${ }^{272}$ See Saunders's Self Impression: Life-Writing, Autobiografiction, \& the Forms of Modern Literature (2010).
} 
potentially ascribe to his version of La Corriveau the family values he deems important. Lessard appears to have a strong affinity with grandfather figures and one can see in his two works an attempt to perform, create, and shape his individual and familial identities around such figures. As the title suggests, Grandfather's Tale recounts the history of human evolution from the perspective and voice of a grandfather figure. Likewise, $A n$ Object of Conviction is channelled through the voice and life of the grandfather figure of the novel, Joseph Corriveau. Joseph is ready to die to save Marie-Joseph, and eventually takes the vital secret pertaining to Dodier's murder to his grave in order to protect his granddaughter Angelique. Lessard's work is thus an expression of an extremely personal project, one of family legacy that allows the author to write his family's story, learn about, and engage metaphorically in a conversation with his Québécois ancestor. Although he attempts to portray Marie-Joseph and the French Canadians as heroic and strong-willed, his presentation of La Corriveau is marked by ambivalence, and the work labours to redeem La Corriveau from her associations with sexual appetite and murder. In the process, his family history almost fully disarticulates La Corriveau from her earlier sociopolitical functions as a nationalist and feminist symbol for Québec.

One of the most fundamental signs of the novel's ambivalence about La Corriveau is its paradoxical method of framing her history. The novel is a multilayered narrative, one that is based on Marie-Joseph's story, but that does not capture her perspective. In fact, the main plot concerns Joseph and the person he tries to protect by condemning himself to death before his court sentence is reversed. Perhaps reflecting Lessard's own gendered authorial position, the novel is structured as a frame narrative that accentuates male voices: Angelique listening to Father Thomas's past constitutes the 
frame narrative, and Father Thomas's memories of his conversation with the imprisoned Joseph Corriveau constitute the narrative nested within. Marie-Joseph's perspective is only provided through indirect speech, twice removed: Joseph shares an account of his daughter's actions and words with Father Thomas, who recalls this information thirty-two years later. Joseph's and Father Thomas's voices dominate the narrative and obscure Marie-Joseph's voice. La Corriveau's "female" legend is thus rewritten as a male historical narrative as it centres on the life and times of Joseph Corriveau. Using multiple frames, Lessard evokes the legend of La Corriveau while keeping a historical and gendered distance.

Lessard's particular affinity with Joseph transforms the legend from a story about a female murderess and familial dishonour into one of male sacrifice, love, and familial protection. Joseph and his daughter both perceive family as a core value, but have different approaches to applying this value during the arduous wartime that is mideighteenth-century New France. Whereas Joseph is ready to sacrifice his life to protect his family in the murder case of Louis Dodier, Marie-Joseph offers sexual favours to a British soldier to protect the family farm, a critical moment in the novel that will be discussed further below. Like Beaulieu's Corriveau Noire and Glover's protagonist, Lessard's character is unafraid to express her flirtatious nature and sexual desires, and ascribes more generally to the wanton woman archetype. Of interest is Joseph's ambivalent reaction to his daughter's wantonness, which seems to crystalize an auctorialfamilial dilemma: Joseph considers his self-sacrifice a heroic act of pure love, but that of Marie-Joseph one of “whorishness.” Insofar as Joseph is a mirror for Lessard, Joseph's aversion to his daughter's promiscuity hints at the author's own ambivalence toward such 
a disreputable woman. Lessard's attempts to manage this unruly figure are evident, for instance, when he equivocates in his epilogue that Marie-Joseph "may have been a bit of a loose woman and may have taken to drinking. Again, implied at the trial but not proven fact. She was certainly a headstrong woman" (Lessard 182). As the narrative progresses, Joseph works through this ambivalence by making a concerted effort to transvalue MarieJoseph's promiscuity into an accepted form of familial protection since the story he chooses to recount to Father Thomas - a story that is passed down to the following generations - necessarily reflects his family culture, "its norms, its values, its goals, [and] its identity" (Koenig Kellas, "Family Ties" 366, italics in original).

In discussing the fate of the Corriveau family if he is to be hanged, Joseph stresses that his wife Francoise will need to remarry in order to get through the harvest. ${ }^{273}$ However, he hopes that Marie-Joseph "will not marry again. She has a reputation! Too many men in her life! Too many husbands dead!" (Lessard 29). Joseph's last wishes for his wife and daughter expose his judgment toward the latter. Whereas Francoise's survival hinges on her ability to remarry, Marie-Joseph's promiscuous and potentially criminal reputation takes precedence over her survival. Joseph's words suggest that if Marie-Joseph were to remain a widow, she could potentially rectify the villagers' assumptions about her. Marie-Joseph's unfavourable reputation certainly does not justify the domestic abuse she experiences, but her loved ones understand it as contributing to the predicaments in which she finds herself. Angelique admits, "Maman seemed to attract trouble. ... she was very beautiful and, of course, she knew it. Everywhere she went men would stop and admire her. ... Even at my young age, I could see how easy it was for her

273 The name "Françoise" is spelled without the cedilla in the novel. 
to be flirtatious and how easy it was for Dodier to react in anger. And, I pleaded with her not to flirt with every man that tipped his hat to her" (Lessard 92). Marie-Joseph's wantonness and impulsive marriage to Dodier put her in dangerous positions, dangers that extend to her family members as Joseph is condemned to death and Angelique also suffers physical abuse deriving from Dodier's anger toward Marie-Joseph.

Like Beaulieu and Glover, but with less conviction, Lessard attempts to portray his Corriveau figure as rejecting the negative connotation of wantonness. During the battle at the Plains of Abraham, the men leave to fight, whereas the women and children are left unattended in the village and must fend for themselves. The British soldiers commit arson, burning the houses in their path. When they arrive at Marie-Joseph's home, one of them hits Marie-Joseph's mother when she tries to resist the destruction. In turn, Marie-Joseph offers herself sexually to the commander of the troops in exchange for his commitment to stop the burning of the houses. She asks the major if he would "like to enjoy [her] pleasures" and after receiving a positive response, orders him to "tell [his] men to put out the fires they've started and to move on. They are not to burn [her] farm" (Lessard 85). Joseph eventually learns about his daughter's actions and accuses her of being a whore. In her "heroic moment," Marie-Joseph's sexual bargain evokes the woman-as-nation trope, for in this context her sexual willingness dramatizes the submission of French Canadians at the hands of British soldiers. However, Lessard's Marie-Joseph is only superficially submissive. In this regard, she most closely resembles Beaulieu's La Corriveau Noire; through their actions and convictions, both female characters instrumentalize their bodies in order to save their people insofar as sex leads to the prevention of farm burnings or national liberation. Whereas Joseph's immediate 
reflex is to think his "daughter is a whore" (Lessard 85), both Francoise and MarieJoseph consider the latter's sacrifice an act of bravery. Francoise defends her daughter's actions. She refutes her husband's rash claims, asserting, "No, Joseph! She is not a whore. She did what she had to do to save our farm. If I were a pretty young woman like her, I would have done the same thing. You men can use guns to fight the enemy as you did at Quebec. We have only our charms to fight them and we use them wisely. It is nothing and I'm quite sure she has no regrets" (Lessard 85-86). Francoise's affirmation that she would have done the same as Marie-Joseph shows solidarity among the female members of the family. In contrast to Joseph who needs time to process and understand his daughter's promiscuity, Francoise is compassionate and intuitively empathizes with her; she understands her daughter's self-sacrifice. After his initial shock, Joseph realizes that his reaction was unreasonable and that calling Marie-Joseph a whore "was the wrong thing to say" (Lessard 85). The shaming of Marie-Joseph's actions is subsequently repudiated and their meaning recuperated through their association with Joseph's familial values. Marie-Joseph, in contrast to La Corriveau Noire, does not specifically desire sexual pleasures, but uses sex as a calculated strategy of defence against the British soldiers. As such, she does not attempt to reclaim wantonness as a form of feminism, but reclaims her actions as the only viable way of saving her family and farm-actions that are feminist in essence since she does not expect a man to protect her. If Marie-Joseph was perceived as a "loose woman," to use Lessard's words, then it was a consequence of Marie-Joseph's desire to protect her family.

Complementing the reframing of Marie-Joseph's reputation for "wantonness" as heroic sacrifice in the name of family, is Angelique's confession to Father Thomas by 
which Lessard revises his family history and fully exonerates Marie-Joseph from all crimes. At the end of the narrative, Angelique confesses to killing Dodier. She explains that in the barn one morning, Dodier was so angry, he was about to kill Marie-Joseph. Angelique grabbed a dung fork and ran directly toward him. She admits, "I buried the dung fork deep into his face, again, and again, and again! I don't remember stopping. As I ran out of the stable, I ran directly into the arms of my Grand-Pere, Joseph" (Lessard 180). In the end, then, Marie-Joseph closely resembles her father Joseph since, by accepting the court's judgment, she sacrifices her life to save her daughter from criminal prosecution. Lessard's self-martyring version of Marie-Joseph is thus nothing like the figure that is notoriously synonymous with witchcraft and malevolence; her absolution decisively rejects that history of antagonistic representations. Even Angelique is exonerated since she is a child who acted to save her mother. Years later, she righteously confesses her crimes to the priest, who absolves her and allows her to find peace in death.

Whereas de Gaspé's and Kirby’s respective Corriveau figures are revenants that symbolically challenge the assimilation of French Canadians into the nation-building project of Canada, haunting and upsetting the image of a harmonious and unified Canadian nation-state, the lack of a revenant figure at the end of An Object of Conviction reflects both Lessard's relative indifference to national questions within Canada (as an American author) and the fundamentally redemptive, integrative nature of his fictionalized family history's revisionism. At a national level, the absence of ghosts implies that the French Canadians have successfully been subsumed into the harmonious and unified Canadian nation-state. This is certainly the implication of the novel's elegiac portrayal of the French Canadians as a noble but conquered people that cannot resist 
British rule. At a more personal level, the absence of the revenant tradition is a function of the way Lessard's narrative, in effect, exorcises La Corriveau's ghost in the very process of remaking the family skeleton into an acceptable forebear and assimilating her to a purified family history. Nevertheless, even if Marie-Joseph does not reappear postmortem as a haunting presence that signifies French-Canadian resistance, her slow death - in this version, La Corriveau is not hanged, but intended to die of starvation and exposure in her gibbet—functions as a sign of her lingering presence in family memory. Although she is not a revenant figure that haunts passers-by like she does in Les anciens Canadiens and The Golden Dog, her extended death can be read as a different kind of haunting: no longer of passers-by in the narrative, but of her close ones such as Angelique and Father Thomas. Her lingering presence in the memory of her family and loved ones can be read as a metaphor for her lingering presence in Lessard's mind as well. Lessard provides a decisive resolution to the mysteries of Dodier's murder and Marie-Joseph's guilt or innocence, but La Corriveau lives on in the form of livinghaunting, remaining "alive" through her descendants.

Analyzing this work alongside Glover's "La Corriveau" further substantiates how the transposition of Québécois folklore into a different context presents several challenges. While Glover attempts to critique English-French relations by placing La Corriveau within an English-Canadian context, Lessard pursues a personal project that relates to writing a fictionalized version of his family history. Despite these radically differing objectives, they encounter similar difficulties that reveal the complexities of repurposing the legend of La Corriveau to non-Québécois contexts. In his short story, Glover subverts gender hierarchies and inadvertently perpetuates the representation of a 
gender hierarchy that favours the image of the heterosexual male, an image that concurrently favours the colonizer, who in this case, is the English Canadian of British descent. Lessard does not subvert gender hierarchies but rather focalizes on Joseph, the grandfather figure of the novel, thereby reinforcing them. A feminist critique of Lessard's focus on a male figure to recount the legend of a female figure (La Corriveau) would indicate that Lessard undermines Marie-Joseph's voice and agency. Lessard neither foregrounds Marie-Joseph as a strong female figure resembling de Gaspé's and Kirby's Corriveau figure (as monstrous females), nor does he present her as similar to those of Beaulieu and Hébert (as feminist figures). Even Marie-Joseph's “heroic” moment ironically perpetuates female objectification through the woman-as-nation trope. Redeemed preeminently through self-sacrifice, Marie-Joseph is celebrated only insofar as she remains a passive character in her own narrative.

Just as the anti-feminist elements of La Corriveau's depiction in An Object of Conviction depart from the feminism of Québécois nationalist interpretations of the legend - and in spite of the narrative's privileging of family history over national history - there are also ways in which the novel's depiction of French-Canadian resistance to the British soldiers undercuts La Corriveau's association with Québécois nationalism. This is especially evident in the way Lessard's attempt to represent French Canadians as a resilient nation is undermined by his emphasis on their oppressed status with respect to the British soldiers. When meeting with Father Thomas in the prison cell, the hot-headed Joseph claims, "they [the English] won the battle, Father. But not the war. They will never conquer us! We will never submit to them! We are French! We are Catholic! We are Quebecois! None of that will ever change!” (Lessard 37). 
Notwithstanding the anachronistic statement that they are Québécois, Joseph’s militant spirit reveals that despite the British Conquest of New France, the French Canadians will resist domination. While Joseph's words appear hopeful, his tone indicates hope for a future that the reader knows has already been quashed. His incarceration and approaching execution symbolize his inability to act on his words and resist the British invasion. Furthermore, Father Thomas who, as the town priest, has a more comprehensive understanding of his community's behaviours and concerns, explains that the French Canadians' spirits have already been "dampened by the frequent British patrols. They serve as a reminder that we are a conquered people" (Lessard 26-27). Whereas Joseph needs to remain hopeful—for himself, for his family, and for his people—Father Thomas is cognizant of the effects of the British Conquest on his villagers and their daily lives. In his desire to showcase the injustices of the way in which the British military rule the French-Canadian population, especially through their treatment of Marie-Joseph, Francoise, and Joseph, Lessard incidentally reinforces an English-Canadian metanarrative of nation in which French Canadians appear ultimately as a conquered people who have been integrated into the Canadian state.

Given the novel's parallel depiction of Marie-Joseph as a self-sacrificing and passive hero like her father, as well as the novel's departure from the revenant tradition that presents La Corriveau as a haunting presence who returns to deal with history's unfinished business, the novel's inability to sustain its depiction of New France as unconquerable once again illustrates the disarticulation of Lessard's familial Corriveau from the feminist-nationalist concerns that have animated the figure's representation since the 1960s. Despite this disarticulation, the novel still foregrounds an interplay 
between Marie-Joseph's story and the "national" story of New France that reproduces the interconnection between femininity and imperialism seen in Beaulieu's, Hébert's, and Glover's respective literary works. On his deathbed, Father Thomas whispers "in a very soft, almost feminine, voice" (Lessard 180). Understandably, Father Thomas is old and lacks energetic vigour in his last moments, but the adjective "feminine" binds the FrenchCanadian population to a colonized position of inferiority. The last words Father Thomas utters to Angelique, “mon ange gardien” (Lessard 181), crystallizes the parallel between Marie-Joseph and the French Canadians since the affectionate nickname was one that La Corriveau often used with her daughter and the last words she also uttered to her daughter before her death (177). The novel's ending demonstrates how, without ever removing the figure of La Corriveau from its Québécois environment, Lessard nevertheless decontextualizes it through the unintentional subversion of its major sociopolitical functions as a nationalist and feminist symbol for Québec.

\section{3 "Dessine-moi dans des habits de sorcière divine": Divinity, Love, and Self- Sacrifice in Poupée de rouille}

Following the Quiet Revolution and in response to Québec's independence movements, Franco-Ontarian writers in the 1970s were similarly interested in promoting and affirming their francophone identity. The emergence of Franco-Ontarian literature was therefore simultaneously coupled with the emergence of what François Paré calls a 
“poétique de l'identité" (“La poésie franco-ontarienne” 122). ${ }^{274}$ Jane Moss argues that Franco-Ontarians sought to “créer un espace pour l'affirmation de l'âme d'un peuple, de mettre en place un lieu de conscientisation collective qui soit aussi un 'lieu social', un point de rencontre dans le langage" ("Le théâtre francophone en Ontario" 71). ${ }^{275}$ Poetry in particular played a significant role in the history of francophone Ontario; indeed, Johanne Melançon and Paré see the efforts of Franco-Ontarian poets in the 1970s as bringing about the social institutionalization of Franco-Ontarian literature. Centring on identity politics, this institutionalization allowed Franco-Ontarians to appear on the public scene and gain a more prominent voice (Melançon qtd. in Tardif; Paré qtd. in Dickson 184). Although the Franco-Ontario literary canon is characterized by a focus on issues of cultural nationalism, some poets (mostly female, Paré notes) preferred to tackle "les textualités plus fluctuantes de l'intime" such as "l'amour, le corps, la solitude, la mort, l'absence et la liberté sexuelle” (Paré, “La poésie franco-ontarienne” 132). ${ }^{276}$ Ménard's work certainly belongs to this second tradition of Franco-Ontarian poetry, especially as “depuis le milieu des années 1990, l’identité franco-ontarienne, liée à la langue française et à la culture canadienne-française, n'est plus un thème d'actualité” (Melançon 186). ${ }^{277}$ Poupée de rouille is the only adaptation of the legend of La Corriveau

\footnotetext{
${ }^{274}$ A poetics of identity. As a side note, in Introduction à la littérature franco-ontarienne, Lucie Hotte and Johanne Melançon divide literature produced in Franco-Ontario into three main categories and periods, namely colonial literature (1610-1866), French-Canadian literature (1867-1969), and Franco-Ontarian literature (1970 to today).

${ }^{275}$ Create a space for the affirmation of the soul of a people, to put in place a space for collective awareness that is also a 'social space,' a meeting point within language.

276 The more fluctuating textualities of the intimate ... love, body, solitude, death, absence, and sexual freedom.

${ }^{277}$ Since the mid 1990s, Franco-Ontarian identity, tied to the French language and French-Canadian culture, is no longer a timely theme.
} 
in poetry form written in the French language (the only other poem being McLeod's " $\mathrm{La}$ Corriveau \& the Blond" (1975) written in English).

Ménard argues that poetry, “c'est notre mode d'expression privilégié, parce qu'il permet des libertés que d'autres genres ne permettent pas" (Ménard qtd. in Tardif). ${ }^{278}$ Indeed, Poupée de rouille does not follow a "traditional" poetic form but what Ménard understands to be a hybrid of poetry and other literary forms. Ménard describes this collection as a conte poétique, that is to say, "ça se lit comme une histoire, il y a un début, un milieu et une fin, mais il y a énormément de poésie aussi. Il y a autant de prose que de vers; c'est très hybride, comme le reste de mon œuvre" (Côté Dupuis, italics in original) ${ }^{279}$ Ménard presents his poetry on the legend of La Corriveau as "une histoire d'amour tragique, percutante et torride" using the five-part narrative structure of a conte that encompasses la situation initiale, l'élément déclencheur, les péripéties, le dénouement, and la situation finale. ${ }^{280}$ His five sections, "La genèse des barreaux," "La soif et les écumes," "La Voix," "Cage de mère," and "Funérailles d'encagée," correspond to each element of the narrative structure, though he also includes a prologue and an epilogue. Whereas the poetic form allows him to delve into the subjects "de l'intime," the conte form evokes oral tradition. The term conte, Lord argues, was used arbitrarily in the nineteenth century since it was often conflated with the literary genre called nouvelle. Despite this confusion, he affirms that one of the distinguishing characteristics of the conte is that it is historically tied to oral tradition and possesses "une forme simple"

\footnotetext{
${ }^{278}$ It's our privileged mode of expression because it allows for liberties that other genres do not.

${ }^{279}$ It reads like a story; it has a beginning, middle, and end, but there is a lot of poetry too. There is as much prose as there is verse; it's very hybrid, like the rest of my work.

${ }^{280}$ A tragic love story, forceful and torrid.
} 
(Lord, "La fragmentation infinie" 54). ${ }^{281}$ Ménard similarly asserts that "sur tous les autres genres littéraires ... le conte possède un avantage exceptionnel : celui de tremper ... ses racines dans les eaux originelles d'un système littéraire oral” (Demers and Gauvin 158). ${ }^{282}$ Poupée de rouille brings this adaptation of La Corriveau closer to the oral roots of Franco-Ontario, a “[communauté] de l'oralité" (Paré, "La poésie franco-ontarienne" 121) whose literature thematizes orality, “omniprésente depuis le début des années 1970 , à la fois comme stratégie textuelle et comme mode de diffusion de la littérature dans une société appauvrie sur le plan institutionnel" (Paré, "Esthétique du Slam" 95). ${ }^{283}$ The conte form also evokes the roots of Québécois culture when orality defined the rural, agrarian society of Lower Canada, as well as the oral transmission of the legend of La Corriveau at its origins. As such, Poupée de rouille is not completely denationalized; while it does not engage in a thematics of national politics, it does evoke nationalism through its formal approach to orality, which recalls Franco-Ontarian and Québécois cultural roots.

Nevertheless, offering an account of La Corriveau's life and relationship with her husband Louis-Étienne "Louis" Dodier, Poupée de rouille strays thematically from nationalist and feminist debates to provide an adaptation of the legend distinctively focused on introspection; the poems dwell on La Corriveau's thoughts, emotions, and love for her husband. In this way, Ménard's version of the legend is more concerned with spirituality than politics. Unlike many adaptations of La Corriveau, especially the nineteenth-century ones wherein the figure of La Corriveau is associated with Satan,

\footnotetext{
${ }^{281}$ A simple form.

${ }^{282}$ More than all other literary genres ... the conte possesses an exceptional advantage: that of dipping $\ldots$ its roots in the source waters of an oral literary system.

${ }^{283}$ Omnipresent since the beginning of the 1970s, at once as a textual strategy and as a mode of disseminating literature in a society that is impoverished at the institutional level.
} 
devils, and witches, Ménard transforms Marie-Josephte into a woman of passion and purity. Positioning her alongside God, Ménard thereby radically challenges past iterations of La Corriveau as malevolent. His literary project resembles that of Lessard in that they both endeavour to delve into the past and adapt the legend of La Corriveau into some sort of personal narrative; Ménard explains that after seeing CBC's La Corrivaux, “j'ai voulu, moi aussi, raconter son histoire, à ma façon. ... Je me suis intéressé à elle parce que j'ai une propension à aimer les antagonistes, les vilains ou les laissés-pour-compte de l'histoire, vouloir à [sic] les chérir, à leur redonner leurs lettres de noblesse et à les rendre plus humains, plus aimables" (É. Dumais, italics in original). ${ }^{284} \mathrm{He}$ is drawn to the prospect of redeeming historical antagonists, not for political reasons, but because he feels ethically driven to humanize these characters. Whereas the personal dimension of Lessard's narrative lies in his attempt to fictionalize his own genealogy, for Ménard, it is his empathy for characters such as La Corriveau that makes his poetry collection a personal project. In both adaptations, the authors present La Corriveau as a loving and self-sacrificing person. As Ménard asserts in the interview for Bible urbaine:

plusieurs artistes comme Anne Hébert, le groupe Mes Aïeux et Victor Levy [sic] Beaulieu, ont revisité et réinventé son histoire. Pour ma part, j'ai voulu dresser le portrait d'une Corriveau aimante, amoureuse et complètement passionnée. C'est une femme cherchant l'absolu de l'amour. Malgré son crime, je dépeins la Corriveau comme une femme humaine, bienveillante. Mon livre offre une autre

\footnotetext{
${ }^{284} \mathrm{I}$, too, wanted to tell her story, in my own way. ... I took interest in her because I have a propensity to love antagonists, the villains and the rejects of history, to want to cherish them, to restore their former glory, and to make them more human, more lovable.
} 
explication concernant ce qui aurait pu lui arriver, une histoire d'amour tragique, percutante et torride. (É. Dumais) $)^{285}$

In his version, then, Marie-Josephte falls madly in love with Louis, a man who is insane and who possesses an inner demon called "La Voix" that he attempts to silence by abusing Marie-Josephte. The latter supports him and allows him to beat her because she believes this is the only way to alleviate "La Voix." She eventually kills him to rid him of his demons and has no remorse for her actions. She accepts her execution with pleasure since it will lead to her eternal union with Louis in the afterlife.

In an article for Le Droit, Ménard explains how he values religion and believes it is important to resituate La Corriveau within a religious framework that was intrinsic to eighteenth-century Lower Canada: "La religion fait partie de moi. La Bible demeure à mes yeux un bijou de littérature et d'histoire. ... j'ai été servant de messe pendant deux années et le discours religieux m'a vraiment marqué. ... vu l'importance de l'Église à l'époque de La Corriveau, je n'avais pas le choix de continuer à diffuser le champ sémantique religieux" (Bergeras). ${ }^{286}$ Glover, Lessard, and Ménard are all compelled by La Corriveau's liminality, albeit in very different ways. In Glover and Lessard's works, recognition of La Corriveau's semantic ambiguity leads to authorial ambivalence: Glover wishes to employ his Corriveau protagonist in a satire of English Canada but she

\footnotetext{
${ }^{285}$ Many artists like Anne Hébert, the band Mes Aïeux, and Victor-Lévy Beaulieu have revisited and reinvented her story. As for me, I wanted to draw the portrait of a loving Corriveau, head over heels in love and completely passionate. She is a woman searching for absolute love. Despite her crime, I paint La Corriveau as a humane woman, benevolent. My book offers another explanation concerning what could have happened to her, a tragic love story, forceful and torrid.

${ }^{286}$ Religion is a part of me. The Bible remains a jewel of literature and of history in my eyes. ... I was an altar boy for two years and the religious discourse made a strong impression on me ... considering the importance of the Church in the era of La Corriveau, I did not have a choice but to continue diffusing the religious semantic field.
} 
ultimately undermines the project of reversing Québec-Canada power and gender hierarchies; Lessard wants to transform Marie-Joseph into a brave, self-sacrificing woman, even as he portrays her as being dishonorably promiscuous. In Ménard's case, the ambivalence in his work emerges from his move away from instrumentalizing allegories in favour of a more personal and religious emphasis. It is thus in this way that his Corriveau figure appears at once as virtuous and murderous, her murder of Dodier embodying a morally transcendent act of providence. Ménard's Dodier is likewise portrayed as an ordinary man possessed by evil, fully deserving of divine forgiveness and of an afterlife in heaven. Poupée de rouille therefore foregrounds ambivalence as a central feature of Ménard's understanding of what it means to be human.

Writers have depicted Marie-Josephte's husbands in contrasting ways, but what they all have in common is that their relationships with Marie-Josephte are destructive. Beaulieu's Ti-Oui favoured his horse over his wife, which led to La Corriveau's sexual dissatisfaction and his eventual death. Hébert's Elzéar forced his conjugal rights onto Ludivine, leading her to resent him even as she remained loyal to him. In Ménard's version, Louis has enraptured the speaker, but is licentious even after their marriage. After losing her unfulfilling first husband, "un semblant d'époux, un demi-homme, / un cœur essoufflé” (Ménard 47), Marie-Josephte falls passionately in love with Louis: toi, mon Louis-Étienne au corps brûlant, à peau d'âtre et goût de rouge, je t'aimais comme un matelot voguant sur un voilier incendié. $(65)^{287}$

\footnotetext{
${ }^{287}$ A wannabe husband, half of a man, / a breathless heart. ... you, my Louis Dodier with a body that burns, with skin of hearth / and a taste of red, I loved you like a sailor navigating / on a smouldering sailboat.
} 
The juxtaposition of fire and water imagery symbolized by Louis's burning body and Marie-Josephte's sail shows the chaotic nature of their relationship in which opposites attract. However, whereas Louis is fire and thrives on expansion, Marie-Josephte's boat continues to burn until there is nothing left and she drowns. This fire and water imagery reoccurs throughout the poetry collection and foreshadows Marie-Josephte's ultimate destruction. In her various encounters with "l'homme / engagé pour aider un pauvre homme sans fils" (Ménard 52), Marie-Josephte eventually becomes pregnant, her "enfant conçu dans l'illégitimité sur le sol de l'étable" (60), and decides to marry Louis out of duty. ${ }^{288}$ However, after their wedding celebrations, they return to their chamber and nus, nous étions à dévorer, savoureux, munificents Isabelle est sortie de l'ombre comme un oiseau de proie nous avons sursauté comme deux pécheurs tombés à la renverse dans les eaux troubles Isabelle s'est arrêtée un moment pour nous crucifier du regard, s'est dénudée devant nous sans pudeur et tu as eu un geste que je n'ai pas encore compris tu l'as invitée à se joindre à nous et le ciel s'est embrasé. (Ménard 70)289

\footnotetext{
${ }^{288}$ The man / hired to help a poor man without a son. ... child conceived in the illegitimacy of the stable grounds.

${ }^{289}$ Naked, we were to devour, savoury, munificent / Isabelle came out of the shadows like a bird of prey / we jumped like two sinners overthrown in troubled waters / Isabelle halted a moment to crucify us with her / stare, stripped in front of us without shame / and you gestured in a way I still do not understand / you invited her to join us / and the sky was set ablaze.
} 
In contrast to the previous passage wherein the speaker and Louis symbolized opposing elements of nature, here they embody a certain complicity before the arrival of Isabelle, the speaker's cousin, who is attracted to Louis and jealous of Marie-Josephte. The speaker offers a simile wherein the couple is compared to a pair of sinners who are both overthrown in troubled waters. ${ }^{290}$ It is only when Isabelle appears as a bird of prey and strips in front of them that "le ciel s'est embrasé," lighting up like fire, thus fuelling Louis's sinful desires.

Louis's perverse behaviour and confusing sentiments toward Marie-Josephte and Isabelle are characterized by his ambiguous symbolism as both fire and water, and ascribed by the speaker to the influence of "La Voix." Appearing sporadically through his life, this voice is a demonic presence that possesses Louis, and Marie-Josephte considers it the justification for Louis's actions. She believes its emergence is what leads to moments of infidelity and violence. It is not only a voice Louis hears in his head, but a source of pain and insanity. The speaker establishes a metaphor between the pain Louis suffers and his inner demon:

la douleur c'est le démon, et de ton vivant, c'était plus souvent le tien que le mien

j'ignore encore quand il s'est éveillé en toi

il lui a fallu une porte d'entrée, à ton cher diable de souffrance, un passage timide, une façon sournoise et

\footnotetext{
${ }^{290}$ Ménard's use of the word "pécheurs" (sinners) is a pun; it sounds like pêcheurs (fishers), which would also work in this context because the term would suggest that Marie-Josephte and Louis are like two fishers overthrown in troubled waters.
} 
délicate de te pénétrer. (Ménard 38) ${ }^{291}$

This pain is compared to "le démon" and the "diable de souffrance," two servants of Satan. If "La Voix" is an evil presence that possesses Louis, then the only way to rid him of it is through exorcism. Francis Young claims that "exorcism defines the 'other', that which is opposed to God's church" (5). Louis, who needs to be exorcized, can consequently be considered as opposing God's church as well.

"La Voix" that takes possession of Louis conforms to a perception of evil that absolves men from any responsibility when they behave improperly, as is Louis's case when he abuses Marie-Josephte and is unfaithful to her. In her examination of gender and religion, specifically of the Church as a male-dominated institution that shapes the way women experience religion, salvation, and evil, Ivone Gebara explains that men and women perceive the concept of evil differently. She writes, "le mal masculin a toujours été vu comme 'quelque chose' qui arrive, qui surprend l'être humain, l'entoure, l'attire" (Gebara 23). ${ }^{292}$ This perception corresponds to Louis's relationship with evil. Indeed, Louis's evil is a "thing" (quelque chose) that takes hold of him. This exteriorization of "La Voix"—-not as an evil that was hidden in his soul, but as one that spontaneously appears in his life - exculpates him of his violence toward Marie-Josephte; he is not

\footnotetext{
${ }^{291}$ Pain is the demon, and during your lifetime, it was more / often yours than mine / I am still ignorant of when it awoke in you / it needed an entrance, your dear devil / of suffering, a timid passage, an insidious and delicate way / to penetrate you.

292 "Evil, as far as men are concerned, has always been viewed as some 'thing' that happens, that takes hold of human beings, surrounds them, attracts them" (4, translated by Ann Patrick Ware).
} 
directly responsible for assaulting her, but rather, this is an adverse effect of the demons controlling his body. ${ }^{293}$

The amalgamation of "La Voix," the conte literary form, and the theme of religion generates a series of problems involving the justification and normalization of domestic violence and emotional abuse. Lord explains that "le discours [du conte] ne problématise pas l'étrange ou la croyance au surnaturel, mais impose sa présence dans l'univers de la représentation, sans résistance rationnelle de la part des acteurs mis en discours ... l'étrange fait partie de l'ordre des choses. Il peut déranger un peu, mais on ne remet pas en doute la réalité de son existence" ("La fragmentation infinie" 54). ${ }^{294}$ This normalization of strangeness, Lord argues, likens the conte literary genre to myths and legends. What this means for Poupée de rouille, which explicitly plants its roots in the legend of La Corriveau, is that while readers might reasonably believe Louis or MarieJosephte is insane (Marie-Josephte's father even warns her that Louis is crazy (Ménard 66)), Louis's demonic possession and Marie-Josephte's acceptance of this possession are rational, mundane phenomena within Ménard's diegesis. As such, the use of the conte form, although meant to empower Marie-Josephte by offering a space for her voice and perspective, problematically normalizes domestic violence. Rather than question why

\footnotetext{
${ }^{293}$ Interestingly, Gebara explains that for women, "le mal est dans leur être" ["Evil is in their very being" (4, translated by Ann Patrick Ware)] (23). In other words, women are inherently corrupt and incarnate evil. This interpretation of evil corresponds both to Marie-Josephte as a historical figure and to La Corriveau as she appears in the various literary works discussed thus far. For further reading on the subject of gender and evil, see Gebara's Le mal au féminin : réflexions théologiques à partir du féminisme (1999) or the English translation by Ann Patrick Ware, Out of the Depths: Women's Experience of Evil and Salvation (2002).

${ }^{294}$ The discourse [of the conte] does not problematize the strange or supernatural belief, but imposes its presence in the universe of representation, without rational resistance from the actors in the discourse. ... strangeness is part of the order of things. It can disrupt a bit, but one does not question the reality of its existence.
} 
Marie-Josephte's experiences of domestic violence and emotional abuse are ongoing phenomena, the supernatural "La Voix" is merely naturalized and thus escapes critical scrutiny. This representation of "La Voix" as a normalized occurrence within the narrative parallels critiques of religion as an institution that perpetuates and obscures such violence, justifying it as God's will.

Like Louis's flames which, when in contact with Marie-Josephte, can only burn and destroy her, this pain, while residing in Louis, extends beyond him and has direct, detrimental effects on Marie-Josephte. This perpetuation of pain and violence reverses Lessard's narrative wherein it is Marie-Joseph's wantonness that causes trouble for those close to her. Playing with the "D" alliteration, Ménard's speaker notes that " $D$ [est] pour douleur" (Ménard 36) and accordingly to "démon" and "diable" as well, and that instead of branding her with an "M" for murder, "on aurait dû m'apposer la lettre D, pour damnable ou / dégueulasse, comme la femme qu'ils croient que je suis" (34). ${ }^{295}$ She is “dangereuse," "dégradante," “dévastatrice," “destructrice," "déchirée," and "déshonorée" (Ménard 34). ${ }^{296}$ The branding of a criminal "was an afflictive sanction, because it was applied to the offender's body, and also a dignitary sanction, because by stigmatizing the convict it exposed him [or her] to social ostracism" (Langbein 193). In the history and legend of Marie-Josephte Corriveau, her branding has most often signalled how the villagers and British military perceived her (a murderer), rather than what she most likely was (innocent). Marie-Josephte explicitly claims that villagers believe her to be "damnable" and "disgusting," emphasizing how her branding and ostracism are based on

\footnotetext{
${ }^{295} \mathrm{D}$ [is] for pain ... they should have branded me with the letter D, for damnable or / disgusting, like the woman they believed I was.

${ }^{296}$ Dangerous, degraded, devastating, destructive, torn, and dishonoured.
} 
false perceptions. These perceptions transform into self-perception as the alliteration spirals into self-degradation and despair. The speaker now sees herself through the eyes of the villagers and characterizes herself using pessimistic adjectives such as "destructive" and "dishonoured." The only way for Marie-Josephte to stop this destruction is by ridding Louis of "La Voix."

Through Dodier's association with Satanic powers and, correspondingly, MarieJosephte's opposition to evil, the latter can no longer function as an evil revenant representing the "return of the repressed," regardless of what that repressed may be. In his analysis of Les anciens Canadiens, Jacques Cardinal explains how La Corriveau acts as a revenant figure, a phantom that needs to be exorcised: "il semble que le récit—à travers la figure même de la Corriveau — soit aussi une façon d'exorciser un fantôme qui, dans ce contexte, évoque la défaite des plaines d'Abraham" as a precursory step toward the construction of a conquest that is meant to be seen as "un événement glorieux et honorable" (27-28). ${ }^{297}$ In other words, La Corriveau symbolizes the defeat at the Plains of Abraham and the failure of the French Canadians in the Seven Year War in de Gaspé's narrative. In order for the English to recuperate this event as a glorious and honourable moment in the history of the nation, the spectre of French-Canadian defeat- $-\mathrm{La}$ Corriveau — must be exorcized from the narrative. This phenomenon was also observable in Kirby's The Golden Dog as La Corriveau's death coincided with the glory of French Canadians battling in the name of the British Crown in the subsequent American Revolutionary War (1775-1783). In contrast, La Corriveau is not associated with such

\footnotetext{
${ }^{297}$ It seems that the narrative - through the very figure of La Corriveau-is also a way of exorcizing a phantom that, in this context, evokes the Defeat at the Plains of Abraham. ... a glorious and honourable event.
} 
historical events and violence in Ménard's poetry, nor is she exorcized. Instead, she is placed within the context of religious good and evil as the one performing the exorcism. As an exorcist, she "speaks with the authority of God to cast out demons" (Young 5). When Louis begs Marie-Josephte "d'assassiner la folie en [lui] en [lui] inscri-/vant le mot Dieu sur le front" (Ménard 94)—Dieu being another "D" word—, she pierces in him quatre trous au visage un pour l'œil du Ciel un autre pour [s]es hurlements un troisième pour [leurs] rivières de lumière et un dernier pour [leurs] îlots d'innocence et [leurs] feux roses. $(97)^{298}$

Although Marie-Josephte is guilty of killing Louis in this version, the murder is an act of kindness rather than one of vengeance or folly as it was in Kirby's and Glover's works. Each puncture mark possesses a positive connotation, whether it relates to mercy (the first and second releasing Louis's soul to heaven and stopping his cries of pain) or love (the third and fourth symbolically commemorating his relationship with Marie-Josephte), and spell together the word Dieu. Marie-Josephte's ritualistic behaviour evokes religious ecstasy. According to June McDaniel, "some Catholic understandings of ecstasy interpret it as a sort of trance state, with the ecstatic incapable of voluntary movement. ... The person has a radiant expression, but cannot see or hear anything, and cannot be returned to his or her normal senses except by a superior. The body falls into ecstasy through the intensity of love of God" (32). Marie-Josephte appears almost unconscious of her actions,

\footnotetext{
${ }^{298}$ To assassinate the folly in [him] by inscribing / the word God on [his] forehead ... four holes in his face / one for the eye of Heaven / another for [his] cries / a third for [their] streams of light / and a last for [their] islands of innocence and rosy fires.
} 
intent on freeing Louis from his pain, as well as on uniting herself and Louis with God. Although she is the one performing the exorcism, through the lens of religious ecstasy, Marie-Josephte can simultaneously be interpreted as the one who is in a state of possession-divine rather than diabolic (McDaniel 25).

Marie-Josephte, in her devotion to both Louis and God, resembles Mary Magdalene, the iconic female figure in religion that has also been conflated with Mary the mother of Jesus, Mary of Bethany, and other Marys from the New Testament. In part, this conflation has led to Mary Magdalene's contradictory representations over the centuries. One such representation relates to Mary Magdalene being Jesus's closest disciple who stayed with him during his crucifixion and to whom Jesus first appears after his resurrection. Marie-Josephte resembles this version of Mary in that she remains loyal to Louis until the very end. Through the exorcism, she metaphorically crucifies him and strongly hopes he will reappear before her in the afterlife. Conversely, Mary Magdalene is at times a reformed prostitute forgiven by God. This representation also corresponds to Ménard's Corriveau figure. Although not a prostitute, Marie-Josephte has been sexualized in other adaptations including Beaulieu's Ma Corriveau, Glover's “La Corriveau," and Lessard's An Object of Conviction. Ménard's adaptation recuperates this image of the reformed prostitute by presenting Marie-Josephte as a woman who engages in premarital sexual relations with Louis and has a child out of wedlock. Her hasty marriage then absolves her of her sinful past and she can thereafter live as a reformed, devout Roman Catholic until her death.

In her devotion to love, self-sacrifice, and virtue, Marie-Josephte no longer represents an evil revenant or the Defeat at the Plains of Abraham, but she remains a 
haunting presence that symbolizes her and Louis's love at the end of the poetry collection. She dreams of their enduring love in the afterlife:

nous nous évanouirons entre les sortilèges maladroits nous hanterons notre vieille maison ensemble jusqu'à ce que ceux qui nous la voleront déguerpissent avec leur grabat

nous condamnerons le vent et nous sifflerons pour lui dans les fenêtres. (Ménard $132)^{299}$

The anaphora "nous" coupled with the future tense evokes Marie-Josephte and Louis's undying presence that will continue to linger even after the poetry collection ends. The words "sortilèges" and "hanterons," as well as the couple's metaphoric metamorphosis into a wind that will whistle in the windows, uncannily echo the representation of $\mathrm{La}$ Corriveau as a malevolent witch, but transform this representation into one disarticulated from malevolence and imbued with love. Marie-Josephte becomes Louis's saviour and redeems him through the exorcism. However, her sacrifices throughout the relationship, and even after Louis's death, go unnoticed. Marie-Josephte's countless, unseen sacrifices parallel Mary Magdalene's unjust transformation from a faithful follower of Jesus to a sexual deviant over the years. With respect to self-sacrifice, Gebara argues that sur la même lancée de l'occultation du mal féminin se situe l'occultation et la non-valorisation du sacrifice féminin. Nous savions que le mal vécu par les hommes, particulièrement la souffrance qu'ils subissent, peut être rédemptrice,

\footnotetext{
${ }^{299} \mathrm{We}$ will faint between the inept spells / we will haunt our old home together until / those who steal it from us flee with their / bed / we will condemn the wind and whistle for it in the windows.
} 
tandis que le mal des femmes, et ici je veux parler du mal comme souffrance, comme renoncement à soi en faveur de l'autre, ne sert presque à rien. Il suffit de se rappeler que, dans le christianisme, la dimension du sacrifice qui sauve est fondamentalement masculine. Le sacrifice masculin est le seul qui a du prix. $(27)^{300}$

This interpretation of male sacrifice in contrast to female sacrifice appropriately applies to Marie-Josephte's situation. Marie-Josephte never blames Louis for his sufferings. His death releases him from his demons, metaphorically restoring him to a peaceful state. In Marie-Josephte's case, however, she silently suffers at the hands of both Charles Bouchard and Louis Dodier. She hesitantly watches and "consents" to Louis performing sexual acts with Isabelle. Finally, her most significant self-sacrifice is to kill Louis, and at the same time, separate herself physically from her loved one. These sacrifices are redeemed, however, by Marie-Josephte's last words, wherein she hopes that through death, she may live with the "freed" Louis eternally. Whereas some figures like Ludivine in Hébert's play wish to escape their husbands' wrath, Ménard's speaker wishes to return to Louis now that his soul has been purged of "La Voix." Existing outside of time and nation, Marie-Josephte and Louis's immaterial, spiritual presences are the ultimate symbols of the denationalization of the legend of La Corriveau.

In many ways, Ménard's introspective version of La Corriveau's legend privileges spirituality. Whereas previous writers such as Beaulieu and Hébert were

\footnotetext{
300 "Just as the evil women endure is hidden, so too their sacrifices are ignored and regarded as worthless. We know that the hard things men endure, especially their sufferings, can be redemptive, but the evil women endure (suffering, self-sacrifice in favor of another) too often counts for nothing. We need only to remember that in Christianity the aspect of sacrifice that is salvific is basically male. Male sacrifice is the only kind that redeems and restores life" (7, translated by Ann Patrick Ware).
} 
interested in the collective and had the Corriveau embody the collective Québécois nation, writers such as Ménard and Lessard decollectivize the figure of La Corriveau in order to see her as an individual or as an ideal whose reference concerns the soul's selfrelation. Such simultaneous divestments of the legend from its embodiment of the collective Québécois nation, nationalism, and feminism amplify Glover's already significant modifications to its cultural meanings. Turning to material culture in Chapter Five, we will see how the legend continues to be transformed and even commodified so that it may enter the global marketplace. 


\section{Chapter 5: Commodifying the Legend of La Corriveau}

La Corriveau's gibbet was returned to Québécois soil on the $250^{\text {th }}$ anniversary of the death of Marie-Josephte Corriveau in 2013 after an extended period of residence in the United States. Stolen and brought to the Barnum Museum in New York in 1851, the gibbet was most likely displayed in the Boston Museum since "P.T. Barnum connaissait personnellement Moses Kimball, le propriétaire du Musée de Boston” and they had "l'habitude de se prêter mutuellement des objets de leurs collections pour les exposer dans les musées respectifs" (Ferland and Corriveau 176). ${ }^{301}$ Kimball's inheritor, the collector David P. Kimball, later gave it to the Essex Institute in Salem, Massachusetts, in 1899, where it was displayed and ultimately moved to the museum's inventory (Ferland and Corriveau 179). Although this information was known to those working in American museums, it was less accessible to Québécois researchers. In fact, "pendant longtemps, les Québécois ont cru que le gibet avait été détruit dans un incendie [le feu au Musée de Barnum en 1899] : c'est l'information qui était véhiculée depuis la dernière mention de cet artefact dans les années 1930" (Ferland and Corriveau 330). ${ }^{302}$ Lacourcière attempted to locate the gibbet in 1970, but his attempts were fruitless. It was only in 2011 that new information was released, leading historian Joseph Gagné to contact the Peabody Essex

\footnotetext{
${ }^{301}$ P.T. Barnum personally knew Moses Kimball, the owner of the Boston Museum ... the habit of mutually lending objects of their collections to be exposed in their respective museums.

${ }^{302}$ For a long time, the Québécois believed the gibbet had been destroyed in an incident [the fire at the Boston Museum in 1899]: that was the information conveyed in the last mention of the artefact in the 1930s.
} 
Museum and inquire about the gibbet (Ferland and Corriveau 333). ${ }^{303}$ At the same time, the Société d'histoire régionale de Lévis initiated similar inquiries and after receiving a positive response concerning the gibbet's location, two of its members went to Salem to confirm this discovery (Ferland and Corriveau 334). In 2013, the Peabody Essex Museum loaned the artefact to the Musée de la civilisation in Québec City for two years - the time it would take to verify the authenticity of the gibbet (Ferland and Corriveau 345). After yet another set of positive results, the gibbet was officially repatriated and became a permanent part of the Québécois museum in 2014 (Ferland and Corriveau 369).

The gibbet is not the only object relating to the legend of La Corriveau to (re)appear in the twenty-first century. The legend has resurfaced in other non-literary forms such as performances. For instance, La Corriveau was featured alongside other Québécois folkloric legends like la chasse-galerie and le Bonhomme Sept-Heures in a show called Légendes fantastiques in Drummondville every summer from 1998 to 2007 (Ferland and Corriveau 299). During the 2013 celebrations of New France, under the theme of "Les héroïnes de la Nouvelle-France," there was an electronic music concert on August 8 called "La Corriveau : 1'électromusicale" that resulted in "une étonnante fusion entre le thème historique et la musique électronique" (Ferland and Corriveau 304). ${ }^{304}$

\footnotetext{
${ }^{303}$ On April 28, 2011, researcher Vicky Lapointe informed her readers through her website that the New York Public Library digitized several hundred thousand works, some of which related to the history of Québec. One of these digitized works was a photograph of La Corriveau's gibbet with information suggesting that the object was currently at the Essex Institute. The object was mislabelled as coming from "St. Vadier" instead of "St. Vallier" (Ferland and Corriveau 332). Furthermore, according to the official Peabody Essex Museum website, due to "their physical proximity, closely connected boards and overlapping collections, the possibility of consolidating the Essex [Institute] and the Peabody [Museum of Salem] had been discussed over the years" ("About PEM: Museum History"). The merger was concretized in 1992 and the institution was renamed the Peabody Essex Museum.

304 The heroines of New France ... La Corriveau: The Electromusical ... a stunning fusion of the historic theme and electronic music. Aside from the translation, I wish to point out that the fêtes de la NouvelleFrance is an annual celebration held every August in Québec City since 1997 to celebrate New France.
} 
Analyses of these various performances of the legend would have certainly been relevant to this thesis, but my lack of access to such material prevented me from including them. Nonetheless, in addition to the emergence of this type of non-literary material, the legend of La Corriveau has also resurfaced in more obviously commercial forms such as collectible postage stamps and even beer that are the focus of this chapter.

Such commodifications of folklore have often been read as a form of cultural betrayal, backsliding, or "selling out." As Martha Sims and Martine Stephens claim, for instance, the emphasis on making money "devalues the expressive and communicative qualities of folklore texts, turning them into meaningless objects” (85). Richard M. Dorson coined the term "fakelore" in 1950 to describe a process that anticipates such judgments, defining it as "the presentation of spurious and synthetic writings under the claim that they are genuine folklore. These productions are not collected in the field but are rewritten from earlier literary and journalistic sources in an endless chain of regurgitation" (60). In other words, he argues that writers, critics, and folklorists alike cater to the mass market by indulging in the creation of popular, unrepresentative stereotypes of myths and legends that are "quaint, cute, whimsical, syrupy, and childlike" (Dorson 60). ${ }^{305}$ Another term related to the commercialization of folklore that similarly posits an authentic folkloric culture that is betrayed by commerce is "folklure." Priscilla Denby coined the term in 1970 to describe how advertisements in mass media portray folklore in such a manner to lure individuals into buying items of folklore, especially

\footnotetext{
${ }^{305}$ Dorson's article, written shortly after Max Horkheimer and Theodor W. Adorno's essay “The Culture Industry: Enlightenment as Mass Deception" (1947), reflects a similar elitist fear of an increasingly engulfing mass culture. However, what Dorson sees as "an endless chain of regurgitation" can also be seen as an endless chain of reinvention.
} 
decorative items such as a replica of King Arthur's sword or a spinning wheel (Denby 118). In both Dorson's and Denby's definitions, the commodification of folklore is embedded in a narrative of cultural decline; the transformation of a myth or legend into a fixed, commercially exchangeable form and its entrance into the marketplace for consumption, in their view, mean an end to its function as a bearer of significant cultural meaning and value. Unlike the narratively complex and historically engaged treatments of the legend in the novels, plays, fictional life writing, and poetry that I have already considered, the recent, more flagrantly commercial forms in which La Corriveau can be seen to circulate — in products like beer, but also in more subtle and pedagogical forms of commercial enterprise like stamps and museums - might seem to bear out such fears.

As I argue, however, even though the emergence of material cultural products like collectible stamps and beer hints at the gradual commodification of the legend as "folklure," they also instantiate new versions of La Corriveau that continue to mediate the image of Québec and its relation to Canada both within and outside of the province. Regina Bendix captures precisely this convergence of commodification and cultural politics when she notes that "folklore has always been a powerful agent in nationalistic attempts at cultural legitimation," even as "the globalization of the Western market economy has led to the further commodification of folklore, that is, the preparation of seemingly unique cultural goods or performances for mass consumption" (276). Without mentioning the word "folklore," Michael Billig speaks of the relationship between commodification and cultural politics in a more general sense when he says that "heritage is a booming industry, successfully marketing the national past as a leisure commodity" (103). In the following pages, we will see how Crown corporations, museums, and local 
businesses nuance the tension between the commodification of folklore (such as that of the legend of La Corriveau through its various object forms) and folklore's traditional role in the politics of cultural identity — how they employ stereotypes of the legend of La Corriveau and how they take into consideration or ignore the histories that produced them. Focusing on the commodification of the legend from Québec's Second Referendum in 1995 onward through contemporary cultural and material production of La Corriveau's folklore in Québec and Canada, this chapter examines La Corriveau's appearance in Canada Post's "Haunted Canada" postage stamps, La Corriveau's gibbet and the narrative produced around it by the Musée de la civilisation in Québec City, and the two Corriveau beers produced by the microbrewery Le Bilboquet located in SaintHyacinthe, QC. I argue that while these highly varied objects—collectible stamps, a museum display, and craft beer-commercialize the legend in different ways, sometimes undermining its cultural significance through commodification and stereotype, their presentation and marketing of new versions of La Corriveau to consumers also highlight important continuities between commodified forms of the legend and earlier forms of cultural politics that, as we have seen, employed the legend to mediate issues of national identity between Québec and Canada. Canada Post is a Canadian Crown corporation and accordingly a bilingual operation, but its Haunted Canada stamp collection remains beholden to the national metanarrative of the dominant English-Canadian culture. The representation of La Corriveau within this collectible stamp series consequently replays the early history of La Corriveau's relation to English Canada and her role within those national narratives as a consolidator of English-Canadian romantic nationalism. The exhibition featuring Marie-Josephte's iron gibbet at the Musée de la civilisation in 
Québec City is a more complex case study because it operates in the province of Québec but largely caters to non-Québécois, anglophone tourists. Developed by Québécois curators, the exhibition engages in a process of self-commodification and selfexoticization that is not unusual in the cultural tourism industry. This process involves the construction of a marketable identity for economic purposes, which, in the case of the museum exhibition, signifies a self-representation of Québec as a gothic space of otherness for anglophone visitors that again recalls early iterations of La Corriveau. Finally, the beers produced by the microbrewery Le Bilboquet are commercialized products that offer the most potential for subtle, subversive counter-discourses. Such a claim might seem surprising, given that the beer series' commercial status appears at first glance uncomplicated by the sort of implicit or explicit public pedagogy found in the offerings of a Crown corporation or the Musée de la civilisation. Nonetheless, operating from within Québec, these products exploit neolocalism — the "deliberate seeking out of regional lore and local attachment by residents" (Shortridge 10)_-and appeal to local, national, and international consumers in ways that suggestively reimagine the history of La Corriveau's role as a gothic figure of Québécois nationalism, offering a portrayal of La Corriveau whose cultural meanings differ for beer drinkers according to their degree of familiarity with the legend.

\subsection{Haunted Canada Stamps: Returning to Old Canadian Landscapes and Debates}

Drawing on Naomi Klein's work on branding and alter-globalization, Ryan Edwardson asserts that national identity is "consumed into existence. Commodities can 
embody and popularize social identities and lifestyles—-such as Nike and 'Just do it' or the Body Shop and environmentalism—-which are in turn confirmed through the consumption of those products" (185). More importantly, "through the consumption of commodities proposing certain myths, symbols, and values, national identities can be popularized and validated" (Edwardson 185). An object as small as a postage stamp can participate in such hegemonic processes by serving as a bearer of meaning for nationmaking projects. David Frank rightfully claims that "postage stamps have usually presented a selective reading of the public identity" in which "some narratives are privileged and others are neglected" (179). He concurs with social historians' interpretation of stamps as "a source of 'government messages' about a country" and affirms that it is crucial to evaluate the type of knowledge they aim to produce (Frank 180). Although Sheila Brennan speaks specifically of the United States, she makes a similar argument. She states that in addition to their function in postal operations, stamps are "objects deeply embedded in culture, with complicated stories to tell" and that they "stand as symbols for nations as distinct political and ideological entities" (Brennan 2-3). The symbolism of stamps gains added significance when they are commodified and marketed precisely for their national, political, and ideological dimensions. Brennan notes that just as "advertisements sold consumer goods by referencing the American past and invoking national symbols to associate purchasing a product with patriotism and good citizenship ... the Post Office Department printed and sold its own products that invoked national symbols and referenced the American past" (4). As commodities imbued with the symbols of national and cultural identities, stamps become, through their consumption, tools of public history and public pedagogies of state-making. 
In 2015, Canada Post featured La Corriveau on a "Haunted Canada" stamp as part of "a three-year series that brings regionally renowned ghost stories to a broader Canadian audience" ("Haunted Canada"). Canada Post published a press release announcing the first issue of five stamps on June 13, 2014. ${ }^{306}$ The stamp "Marie-Josephte Corriveau" was part of the second issue that was announced on September 14, 2015. This series also included the "Brakeman" from Vancouver, BC; the "Caribou Hotel" in Carcross, YT; the "Red River" in Winnipeg, MB; and the "Halifax Citadel" in Halifax, NS. The third and last issue of Haunted Canada was announced one year later, on September 8, 2016. ${ }^{307}$ All of these limited-edition stamps, which are no longer available for purchase, were designed by Lionel Gadoury and Kammy Ahuja, and illustrated by Sam Weber. ${ }^{308}$ Some of the designs are now sold as postcards in Canada Post offices and online.

\footnotetext{
306 This issue includes "Ghost Bride" from AB; "Count of Frontenac" from QC; "Phantom Ships" from NS and PEI; "Haunted" from ON; and "Ghost Train" from SK.

${ }^{307}$ The last issue features the "Bell Island Hag" from NL; the "Dungavon Whooper" from NB; the "Lady in White" from QC; the "Phantom Bell Ringers" from PEI; and the "Winter Garden Theatre" in ON.

${ }^{308}$ Gadoury graduated from the Ontario College of Art. After working various jobs, he currently works at Context Creative, a business he co-founded. Context Creative works with institutions such as Ontario Ministry of the Environment, Toronto Hydro, Hydro One Networks, and Canada Post (Gadoury; "Meet the Team"). Under Gadoury's leadership, Context Creative has won over 50 awards from the Canadian Marketing Awards, ADCC Directions, RGD Design at Work, the CPRS ACE Awards and the GDC Graphex awards. Kammy Ahuja studied graphic design at George Brown College in Toronto, ON. She has won numerous awards and was the associate creative director at Context Creative from 2014-2017 (Ahuja). Born in Alaska and raised in Deep River, ON, illustrator Sam Weber studied graphic design and illustration at the Alberta College of Art \& Design. He then completed a master's at the School of Visual Arts in New York. He currently resides in Brooklyn and illustrates for New York Times, Rolling Stone, Time, DC/Vertigo Comics and Random House, among other newspapers and publications (Bedrossian; Creative Bloq Staff).
} 


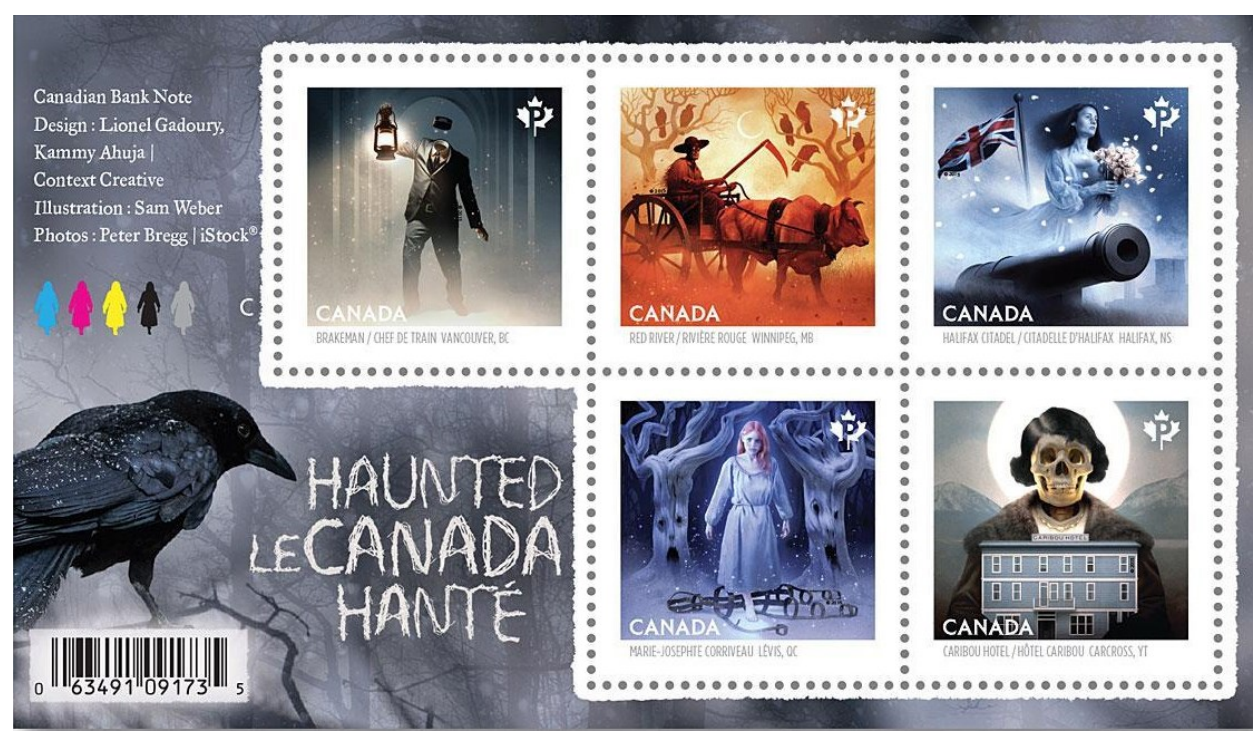

Illustration 1 Haunted Canada Postage Stamps, Second Collection

Like all of the stamp series produced as collectibles by Canada Post, the Haunted Canada stamps are commodities that can be bought by Canadians or marketed as part of an international tourist experience wherein tourists may purchase and collect these small objects commemorating their visit to Canada. One of the primary objectives of Canada Post's collectible stamps is to connect its Canadian consumers with the nation's past by producing stamps whose images reference popularly recognizable figures, places, events, and hegemonic narratives of Canadian history and national formation. These collectible stamps are "curated by a panel of specialists to highlight the nation's history" and as Canada Post suggests, anyone can "own a piece of Canadian history with our stamps," a comment that explicitly encourages the consumption of public history ("Collectible Stamps and Coins"). Beyond connecting Canadian consumers to Canadian history, Canada Post wishes to ensure that their stamps "instill pride in their country in the minds and hearts of all Canadians" and "are of interest and have popular appeal to broad segments of the Canadian population" (Library and Archive Canada). Indeed, each stamp is "designed to reflect Canada's distinct history and people" ("Collectible Stamps and 
Coins"). The Stamp Advisory Committee, whose role it is to select stamps and themes for stamp collections like Haunted Canada, requires that the stamps be primarily related to Canada and of national interest and significance; evoke Canadian history, traditions, accomplishments of natural heritage; illustrate the social, cultural, political or economic life of Canada; commemorate the birth, the work or an event in the life of deceased persons recognized as having made outstanding contributions to Canada; [and] foster a spirit of national and international goodwill and understanding. (Library and Archive Canada) These objectives leave little question about the mandate of Canada Post and its Stamp Advisory Committee to draw on Canada's various histories and cultures to appeal to "all Canadians." An assessment of Canada Post's achievement of these aims is obviously beyond the scope of the current project. With respect to the Haunted Canada stamp collection in particular, however, it is striking that it references only the history and culture of Canada's two founding nations, tacitly thematizing a metanarrative of nation in which the ghosts of English- and French-Canadian settlers from various regions are gathered into a unified national series or "story." The stamp series and its various regional ghosts function here as a homology for Canada, but one wonders which version of Canada? And what version of La Corriveau does the stamp make visible? As I argue in more detail below, the fact that La Corriveau appears triumphant and free on the stamp on which she is featured recalls, in some ways, Beaulieu's and Hébert's respective versions of the figure as a hopeful nationalist symbol for Québécois society. Yet, the stamp also seems depoliticized by its context as a "regional" instance; it is given equal value to all other Haunted Canada stamps (just as Pierre Elliott Trudeau's multicultural 
policy placed Québec on equal ground with other cultures within Canada). The version of La Corriveau that circulates in the Haunted Canada stamp series thus ultimately appears to be a domestication of the nationalist Corriveau figure whose new role is simply to signify the legend's French-Canadian historicity as a part of Canada's accepted national metanarrative.

The stamp of La Corriveau's significantly reduced political symbolism and cultural significance to Québec derive in the first instance from the inherent attempt in the Haunted Canada collection to showcase a history and geography that represents "all" of Canada. The theme of Canada's "spooky stories" fulfills Canada Post's and the Stamp Advisory Committee's objectives as the Haunted Canada stamps and postcards become a way of highlighting diverse Canadian landmarks such as the Montmorency Falls in Québec City, QC, or the Caribou Hotel in Carcross, YT. Furthermore, a number of these spaces recall pivotal moments in Canadian history. For example, the "Red River" stamp, which portrays a grim reaper driving an ox cart, is meant to represent the narrative about a "night sentry at Fort Garry who saw a Métis couple driving an ox cart disappear into thin air when he called for them to halt" ("Haunted Canada"). At the same time, however, it also strongly evokes the Red River Resistance, the uprising involving Louis Riel and the Métis. Likewise, the Corriveau stamp can be read as a symbol for the fall of New France. Joel A. Sutherland, one of the authors of Scholastic's Haunted Canada book series, which is affiliated with the eponymous stamp series, affirms that the stamps "are an incredible showcase of Canadian history and Canadian geography_all good ghost stories inherently deal with the past and the stories cover coast to coast" ("Haunted Canada"). Canada Post relies on a "folkloric" populist discourse for selling stamps that 
will appeal to "all Canadians." Thus, it universalizes the legend of La Corriveau, typified in the media's various publications, advertisements, and news releases related to such commodified products. And yet, it is precisely Canada Post's decontextualization and commodification of La Corriveau that reconfigures the Québécois legend so that it may work in the service of a culturally dominant English-Canadian patriotism.

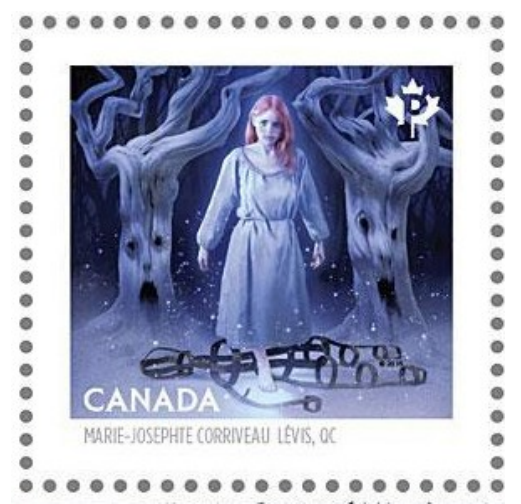

\section{Illustration 2 Stamp Depicting La Corriveau}

Although the stamp version of the figure of La Corriveau evokes the iconography of the Québec nationalist theatre productions, it ironically decontextualizes the legend by removing from it the complexities of its political and cultural background. An article published on the Canada Post website describes the stamp of Marie-Josephte Corriveau as follows: "in Lévis, Quebec, the tortured soul of Marie-Josephte Corriveau still roams the roads and forests. After being arrested, tried and executed on charges of killing her husband, the reputed 'murderess of New France' was placed in an iron cage and her dead body left hanging in a tree" ("Haunted Canada"). "Tortured" is a particularly interesting word choice as it presents here a double meaning; it serves as a metaphor to suggest that Marie-Josephte is a restless spirit and erroneously implies that she was tortured to death in the gibbet. Coupled with words like "killing," "murderess," and "dead body," the text certainly underscores the gothic dimension of the legend. This description of the stamp 
omits details about French- and English-Canadian politics, sticking instead to the facts relating to La Corriveau's gruesome execution and the gothic dimension of the folklore that made it an enticing oral narrative to tell around the campfire. The stamp itself shows a red-haired woman walking between two trees portrayed as having haunting faces. Marie-Josephte steps atop the iron gibbet. Her red hair evokes her witch-like representation as "it is a widespread folk belief that witches have red hair, perhaps because red hair is unusual" (Guiley 286). Despite her association to witchcraft, she is valorized as a young and attractive woman. Indeed, while echoing the gothic witch found in nineteenth-century texts, she is certainly not a threatening, monstrous female, and arguably lacks a "fear factor." Coupled with her beauty, her white skin and dress evoke purity, and recall previous versions of the figure such as Beaulieu's La Corriveau Blanche, Hébert's Ludivine, and Ménard's Marie-Josephte, but without any of their political implications. Although the positioning of La Corriveau above rather than in the gibbet evokes triumph, liberation, and even revenge, her femininity - a trait traditionally associated with subservience (Pigeon 37)—confines these meanings to a local domestic dispute and transforms her into a domesticated figure rather than a national Québécois allegory. La Corriveau thus rises from her cage to travel the world, not as a Québécois stamp, but as a Canadian one.

The reduction of La Corriveau's political history is not surprising. As objects that are "produced to make money from tourists," stamps purposely "imprint specific images of sites on the memory of persons keeping the trinket that also simplify complex realities of history" (Brennan 5). In addition to being artistic and aesthetically pleasing, they must metaphorically be digestible for tourists and therefore pare down the sociohistorical 
contexts relating to the various regions, landmarks, and notable figures in Canada. Furthermore, stamps are such small objects that they necessarily reduce the amount of historical, geographical, and political information that can be conveyed. The stamp of La Corriveau cannot productively provide purchasers with a nuanced picture of the Québécois political landscape. This reduction is also apparent in the fourteen other stamps of the series. Nevertheless, the image and description of the stamp of $\mathrm{La}$ Corriveau manifestly do capture the gothic nature of the legend and do domesticate the figure's militant spirit. The stamp and its advertisement by Canada Post thus articulate narratives that allow the legend of La Corriveau to continue to circulate and be reinvented as a mediator of Québec's role within metanarratives of nation.

While they are meant for "all Canadians," the Haunted Canada stamps do not reflect Canada's pluralist composition in any way; they demonstrate a reversion to English-French dualism and consolidate the history of Canada's English and French founding nations. Canada Post's antiquarian endeavour to collect and feature Canadian legends in this particular stamp series thus dovetails with settler colonial versions of Canada's historical metanarrative since the legends only recall the history of white (and mostly English) Canadians. While Gadoury, one of the stamp designers, claims that these are "our nation's most richly nuanced tales" ("Haunted Canada Posted on Sept. 08, 2016"), they only represent a fraction of the Canadian population. Haunted Canada's attempt to collect and share a variety of stories that represent the nation only gestures weakly at diversity, while consolidating white settler hegemony. In such a way, the stamps are "a political tool that caters to the national majority (or majorities - as in the Canadian case) through ethnicization, racialization, and incorporation of others into a 
fixed structure of material and symbolic ethnosocial stratification" (Winter 45). Through the absence of their representation in Haunted Canada stamps, internal others have been fully incorporated into the fixed structures of which Elke Winter speaks.

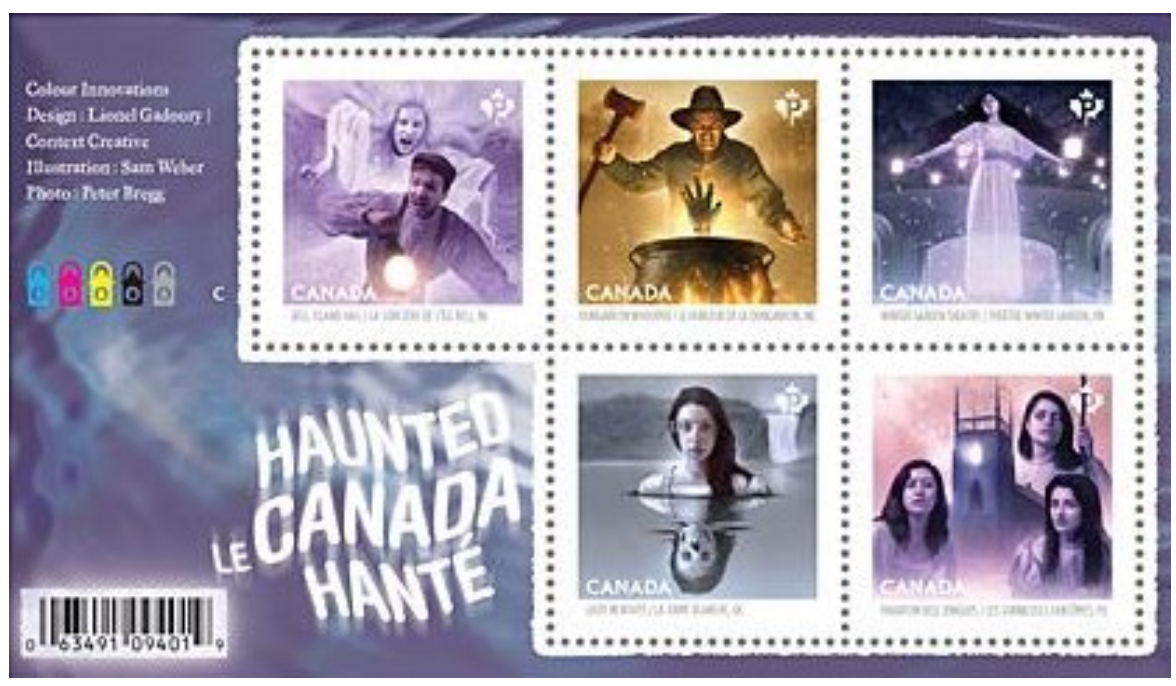

Illustration 3 Haunted Canada Postage Stamps, Third Collection

In more finer-grained ways, the Stamp Advisory Committee's selection of gothic tales is telling in terms of how the "gothic discourse is used to mediate forgotten histories and, in some instances, initiate forms of cultural mourning (signalling a loss of cultural memory/history resulting from colonialism or migration or, alternatively, because of a perceived illegitimacy in one's tenancy of the land)" (Turcotte and Sugars xi). The almost total lack of Indigenous presence in the stamps over the course of the gradual three-year release of the Haunted Canada collection naïvely reproduces one of the strategies of settler gothic, which is to deny the presence of Indigenous ghosts while asserting the presence of settler ghosts such as La Corriveau. The Corriveau stamp substantiates settler ghosts' claim to perennial existence on the land as it partakes in a larger discourse of Indigenous dispossession wherein both English- and French-Canadian settler ghosts are indigenized through the absence of Indigenous representation (Sugars, Canadian Gothic 
143). A striking case of this Indigenous absence pertains to the aforementioned "Red River" stamp. Canada Post describes how a "night sentry at Fort Garry ... saw a Métis couple driving an ox cart disappear into thin air" ("Haunted Canada"). While the description suggests that the stamp depicts two Métis ghosts, the actual image glaringly omits the Métis couple in favour of the solitary figure of a ghostly night sentry, whose skeletal remains drive the ox cart, having seemingly displaced the Métis couple. The "Red River" stamp thus translates the disappearance of the Métis couple in the ghost story into a version of the "vanishing Indian" trope. Concomitantly, like the ghostly image of La Corriveau rising from her gibbet, the transformation of the night sentry into a ghost evokes the idea of settlers' longstanding presence on the land, confirming an indigenizing wish-fulfillment wherein English and French Canadians become indigenous to the land. Indeed, the first issue of Haunted Canada released stamps featuring British soldiers at Fort George, Niagara-on-the-Lake, ON, and the French Governor Louis de Buade in front of the Fairmont Le Château Frontenac in Québec City, symbols of the powerful French and British authorities who settled on the land. This indigenizing discourse is intrinsic to English Canada's nation-making metanarrative. In the same issue, one of the stamps features a train meant to be the St. Louis Ghost Train, and "the spectre of a long dead Canadian National Railway (CNR) conductor who literally lost his head in the 1920 s to a passing train" ("Haunted Canada Issued: June 13, 2014”). While an entertaining, spooky ghost story, the symbolism of the image recalls the significance of trains in Canada's nation-building process. The Canadian Pacific Railway represented the iconic dream of connecting Canada's coasts, but a "related later version of sovereignty and nation building was forged under the first Mackenzie King government including the 
reorganization of the Canadian National Railways" (Doern et al. 31). Canada's nationbuilding project and national dreams are thus premised on Indigenous erasure.

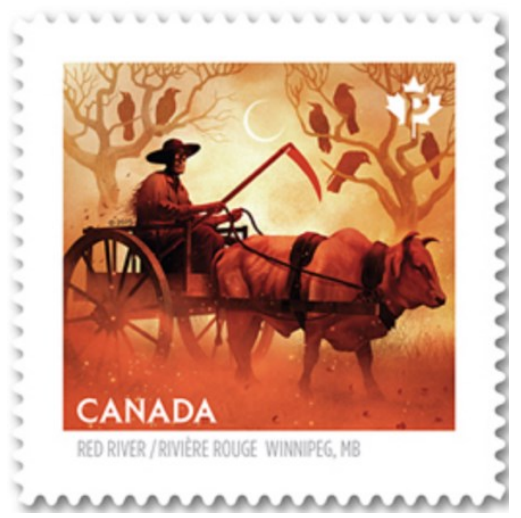

Illustration 4 Stamp of the Métis Ghosts at Red River

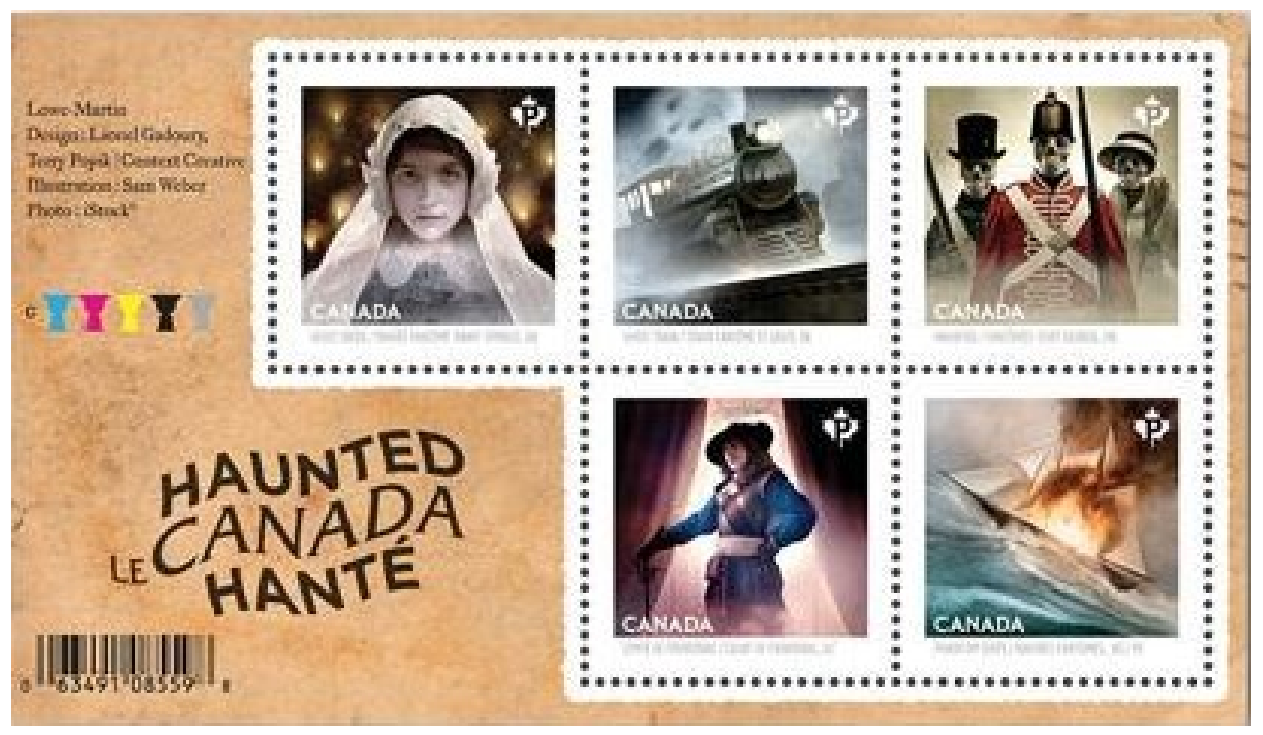

Illustration 5 Haunted Canada Postage Stamp, First Collection

The Haunted Canada stamp series offers a new iteration of La Corriveau that

draws on old versions of the figure and significantly revises them. As a witch, she recalls de Gaspé's Corriveau figure. However, her charming appearance makes the figure devoid of malice and hostility. The figure's rebellious nature—epitomized in her "rebellious" hair colour and stance over her imprisoning gibbet—evoke the iconography of Beaulieu's and Hébert's figures, but this rebellion is softened by the stamp's symbolic depiction of 
serenity (La Corriveau's foot is gently positioned in front of her, and there is a light snowfall). In this context, her nationalist function is to serve as a domesticated placeholder for a feminine Québec. Whereas La Corriveau Noire and Ludivine challenged the trope of Québec as a bride to Canada, the Haunted Canada version of La Corriveau can be seen as re-presenting her as a bride figure; she is feminine, beautiful, and dressed in a simple off-white gown. Finally, her pale skin also makes her ghostly, suggestive of her role as an indigenizing settler ghost, as implied by the larger patterns of indigenization and nation-building in the Haunted Canada stamp series.

\subsection{The Return of La Corriveau's Gibbet to Québec City}

Like stamps, museums have a commercial dimension but also play a pedagogical role in nation-making and in the dissemination of national identity. Whereas Canada Post's La Corriveau stamp participates in an ostensibly universal but actually EnglishCanadian settler metanarrative of Canadian history and nationhood, the presence of $\mathrm{La}$ Corriveau's gibbet at the Musée de la civilisation in Québec City functions differently. As a public institution in Québec mounting an exhibition on Québécois history, the museum's role is to mediate the depiction of Québec for a variety of visitors. Although museum studies in the last decades have made it clear that museums are "institution[s] of recognition and identity par excellence" (Macdonald 4) that negotiate "the complex relations between narrative, space and identity" (MacLeod et al. 1), the Musée de la civilisation's specific approach to the representation of Québécois identity reflects its simultaneous solicitation of provincial, national, and international visitors. When the Musée de la civilisation first opened its doors in 1988, Québécois nationalism was well- 
established. Some individuals thus sought to create a museum that would celebrate popular arts and traditions or "un musée de l'homme d'ici" (Côté 114-15). ${ }^{309}$ This goal is enshrined in the Musée's first core objective, "to make known the history and the various cultural elements of our civilization, particularly the social and material aspects of the cultures of the occupants of the territory of Québec and the cultures that have contributed to the enrichment of those cultures" (Légis Québec). Nonetheless, those directly involved in the process of the museum's creation promoted the notion of universal citizenship and “ont préféré se concentrer sur une dimension sociale beaucoup plus large, prétextant qu'un citoyen du Québec est aussi un citoyen des Amériques et un citoyen du monde. Ils ont bien sûr souligné l'enracinement de la société, mais aussi son ouverture au monde" (Côté 114-15). ${ }^{310}$

This desire to view the "citoyen du Québec" as a world citizen and the museum's correlative interest in courting national and international visitors sometimes led to stereotypical evocations of Québec's past, as is the case, I argue, with the museum's framing of La Corriveau's gibbet. In what follows, I analyze the exhibition "Sortir de sa réserve : 400 objets d'émotion," which puts on display La Corriveau's gibbet. I argue that the section of the exhibition that displays the gibbet reinvents Québec as a gothic space for museum-goers. Like the Haunted Canada stamps, the museum exhibition attenuates La Corriveau's complex political and cultural history. And yet, whereas the stamp collection's reinvention of La Corriveau revealed its imbrication in a Canadian

\footnotetext{
${ }^{309}$ A museum of man from here.

${ }^{310}$ Preferred to focus on a much larger social dimension, claiming that a citizen of Québec is also a citizen of the Americas and a citizen of the world. They, of course, underscored the roots of the society, but openness to the world as well.
} 
metanarrative of national harmony, the Musée de la civilisation's sensationalistic recontextualization of the gibbet within a fetishistic display of objects of crime transforms the artifact into a self-exoticizing stereotype that recalls and emphasizes a gothicized Québec.

The year 2013 marked the $250^{\text {th }}$ anniversary of Marie-Josephte Corriveau's death and the return of La Corriveau's iron cage to Québec City. The cage is part of the Musée de la civilisation's national collection, and was on display as part of the exhibition "Sortir de sa réserve : 400 objets d'émotion" from February 2018 to September 2019 in celebration of the museum's thirtieth anniversary. ${ }^{311}$ In a press release, the museum's executive director, Stéphan La Roche, communicated that the goal of the exhibition was to share "the memory of our [Québécois] society," as well as to generate "emotions" and "intergenerational dialogue" ("Communiqué de presse : Sortir de sa réserve"). At the entrance of the exhibition was a panel titled "The objects that got the museum started." The timeline indicating the enlarging of the museum's collection focused not only on the reception or purchase of numerous items, but also provided an explicit commentary on Québécois identity and nationalism. For instance, underneath the first date, "1920s," the description reads: "Quebec was seeped in nationalism that prized an idealized past and glorified the French heritage. In the first quarter of the $20^{\text {th }}$ century, objects were primarily collected for their illustration of this identity" ("Sortir de sa réserve"). The section "1960s" reads, "the Quiet Revolution was a favourable backdrop to affirm Québécois identity. Cultural heritage was indeed very popular, and the idea took shape to create a social museum with a local focus" ("Sortir de sa réserve"). The rest of the

\footnotetext{
${ }^{311}$ The exhibition's English title is "Secrets Uncovered: 400 Objects, a World of Emotions."
} 
timeline similarly emphasizes Québécois identity and culture, therefore suggesting that the objects in the exhibition reflect Québécois society.

The exhibition delves extensively into Québécois history, celebrating it through nine main themes: "s'enraciner," "habiter," "apprendre," "jouer," "se transporter," "s'élever," "s'exprimer," "paraitre," and "se perdre." 312 Some of these themes clearly touch on nationalism and identity. For example, the first theme — which can be interpreted as promoting a settler colonial, indigenizing discourse that problematically omits mentioning Québec's colonization of Indigenous lands—is described as follows: "putting down roots means choosing somewhere to call home. It's about connecting with and belonging to the place where you live and letting it shape your identity. About finding somewhere you can thrive. Humans have a profound need to feel at home- to be part of a community with a shared identity and shared values" ("Sortir de sa réserve"). The description continues, but in reading this panel and navigating through the exhibition, visitors may feel an affinity to the objects as they remember items of their past, learn about a past and culture that is not theirs or that they have not experienced directly, or some combination of the above. As indicated by the second theme, they are invited to "inhabit" the other in a very similar way to Glover's English-Canadian protagonist who attempts to inhabit the Québécois other.

La Corriveau's gibbet is located near the end of the exhibition in the section entitled "losing yourself." Directly in front of the cabinet in which the gibbet is displayed is a spotlight illuminating a placard with the words "se perdre." Whereas themes

\footnotetext{
312 The museum panels translate the themes as "putting down roots," "inhabiting," "learning," "playing," "traveling," "touching the divine," "expressing yourself," "appearing," and "losing yourself."
} 
including "learning" and "playing" may generate "positive" responses from visitors since they are constructive verbs that describe, for instance, the healthy growth and development of children, the theme "se perdre" has a negative connotation of loss. In this case, it may connote a lack of knowledge about one's identity. The description reads, crossing lines, provoking, going off the beaten trail, bending the rules, breaking taboos, and thinking outside the box are all defining aspects of human behavior. On the outer edges, there's a thin line between what's socially acceptable and what isn't. Getting lost in the vagaries of a world that exploits, abuses, and intimidates can lead to extremes — to a point of no return. ("Sortir de sa réserve") The semantic field of the description reinforces the negative connotation surrounding "se perdre," as one can infer from the words "beaten," "taboo," "exploits," "abuses," and "intimidates." The notion of crossing lines of social acceptability also evokes transgression. It is no wonder, then, that this spotlight would be placed directly in front of the gibbet. This placement locates Marie-Josephte Corriveau at the heart of transgressions_-between British and French, English and French spheres, man and woman, and many other binaries. The museum narrative one can derive from this signpost is that visitors are entering a “dark," perhaps even shameful part of Québécois history. This segment of the exhibition is not the "norm" of Québécois culture, but rather the exception; like the Haunted Canada stamp of La Corriveau, the "se perdre" section is, in some ways, a return to Québec as a gothic space.

The display encompassing the gibbet of La Corriveau weaves an intricate narrative relating to noteworthy crimes and mysteries in Québécois history. On the left of the gibbet, there is an anatomical model, rifle cartridges from nine different calibres, and 
the death mask of La belle inconnue. The lack of interpretive text about the first two objects draws the visitors' attention to the mask, specifically because there is more to read and learn about it. The identification plaque informs visitors that:

in 1936, a shipwreck not far from the Port of Montreal caused several victims, including a young woman. There were no clues about her identity except that, on her arm, she had an intriguing tattoo, which few women had in 1930. Dr. Rosario Fontaine from the Laboratoire de sciences judiciaires et de médecine légale moulded this mask to help identify the woman. The tattoo and the mask were preserved, but in vain. The young woman would forever remain an enigma, a "beautiful stranger." (“Sortir de sa réserve”)

Placed in conjunction with the gibbet, the mask raises questions about transgressive women, from women such as La belle inconnue who had tattoos, to La Corriveau who was considered promiscuous. The mystery surrounding the identity of La belle inconnue also evokes the mystery surrounding the true identity of Dodier's murderer. 


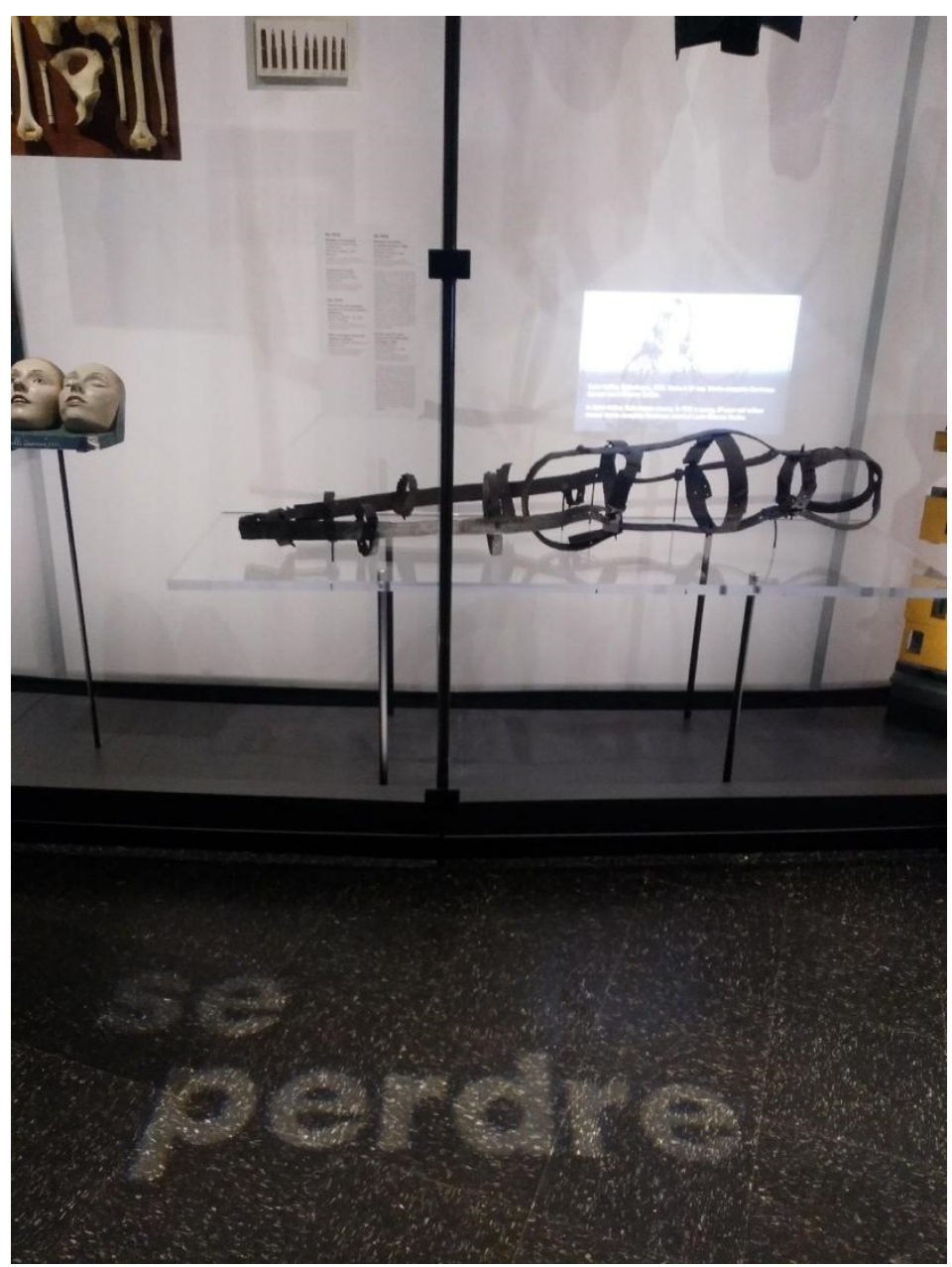

Illustration 6 The Iron Gibbet with a View of the Bottom and Left Sides 


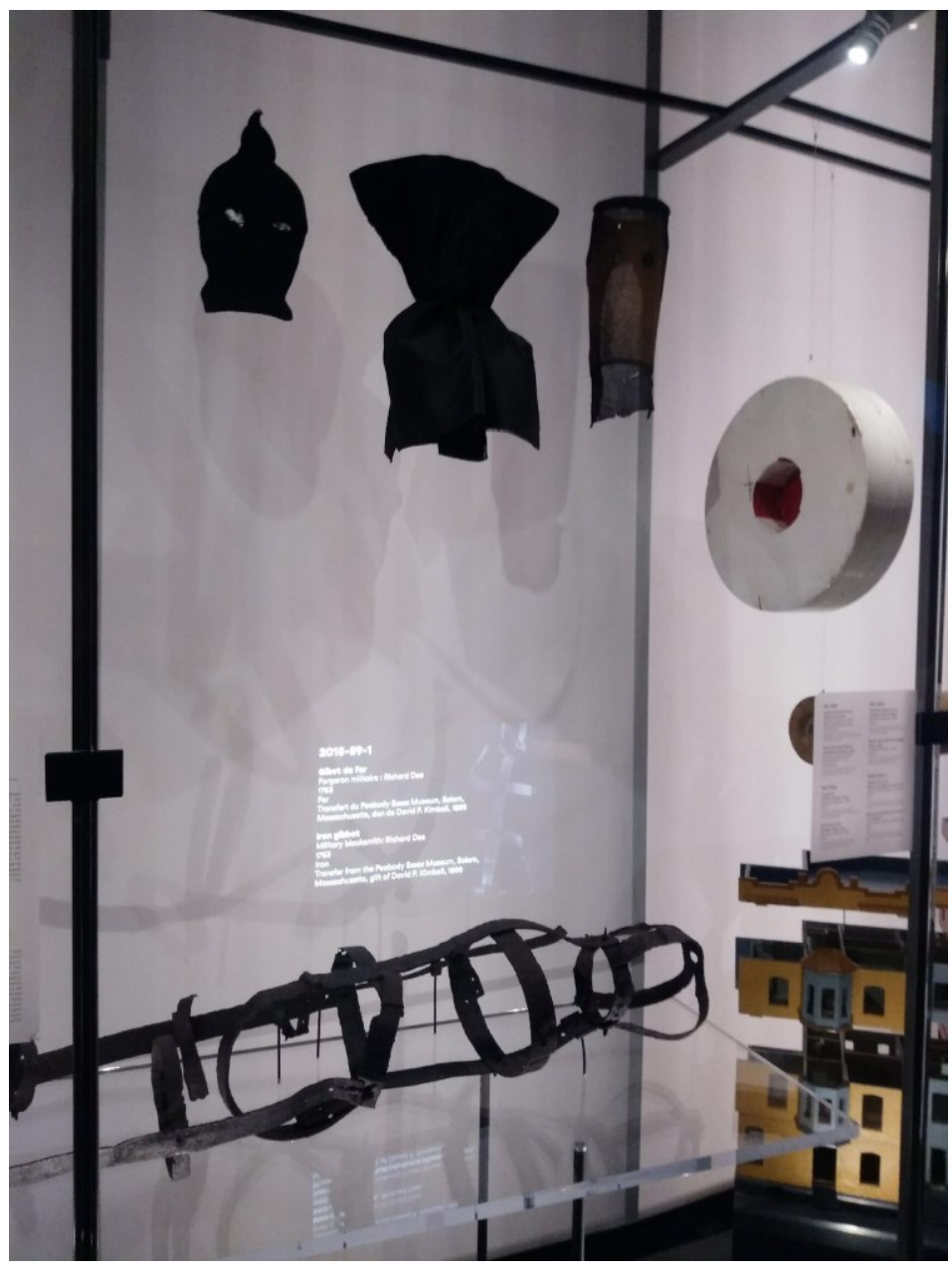

Illustration 7 The Iron Gibbet with a View of the Top and Right Sides

Above the gibbet are displayed a hood from the Place Versailles holdup case, a hood from the Zéphyr Viau case, and a mask from the Hochelaga Bank case. In contrast to the first identification plaque with little descriptive information, the identification plaque for these three artefacts contains no information whatsoever aside from the objects' respective identification numbers, sources of provenance, dates of origin, and dates of arrival in the museum's collection. To an unknowledgeable visitor, the balaclavas hanging above the gibbet might evoke execution since, as it is noted in the informative video playing behind the gibbet, La Corriveau was executed for her crime. 
On the right side of the gibbet are items that seem unrelated to the legend of La Corriveau but that advance the theme of murder. The items include a ballistics model, an anatomical model, and an architectural model, all from the Delorme Affair. The Delorme Affair refers to the murder of Raoul Delorme, whose body was found on January 7, 1922, in a snowy field in Snowdon, Montreal. This case began with the death of Raoul's father. Upon his death, the latter bequeathed the majority of his belongings to Raoul, some to Raoul's two half-sisters, and barely anything to Raoul's older half-brother Adélard. Subsequently, Raoul was killed with six shots to the neck and head. Adélard was the main suspect in Raoul's death as investigators believed he was jealous of the latter's inheritance. This incident attracted much public attention because it was unimaginable at the time that as a Catholic priest, Adélard could commit fratricide. After a series of trials against Adélard that included new technological methods including ballistics analysis and handwriting analysis, Adélard was declared innocent. One article in La Presse published on February 15, 1922, asserted that "jamais, dans les annales criminelles du Canada, un meurtre n'avait encore suscité un intérêt aussi général et considérable” (“L’affaire Delorme"). ${ }^{313}$ The ballistics models, anatomical model, and architectural model were used during the trials.

As visitors arrive from the left and move through the exhibition toward the exit near their right, they are thus exposed to various items that amplify the most sensationalistic, lurid, and gothic aspects of La Corriveau's history. The presentation of a mysterious woman (La belle inconnue) foreshadows the narrative of La Corriveau

\footnotetext{
${ }^{313}$ Never, in the criminal annals of Canada, has a murder ever generated such general and considerable interest.
} 
featuring a mysterious killer. Moving toward the right, directly behind the spotlight, the gibbet becomes the focal point of the "se perdre" section. It is accompanied by a video presentation that provides information on Marie-Josephte's life with Louis-Étienne Dodier and her troubles, as well as the soundtrack "La Corrida de la Corriveau" by the popular Québécois band Mes Aïeux, a song that recounts the murder of La Corriveau's numerous husbands. The items on the right detailing a series of trials relating to murder (The Delorme Affair) recall Marie-Josephte's own series of trials for homicide. Finally, hanging in the balance above the gibbet is an image of Marie-Josephte's impending execution. At the centre, the Zéphyr Viau balaclava also relates to a case of poisoning that subtly evokes La Corriveau's representation as a poisoner.

This combination of objects highly sensationalizes the legend of La Corriveau. Indeed, the fact that this display is at the end of the exhibition suggests that it is meant to generate a high-impact response. The theme of murder is certainly prevalent here, but more importantly, it is presented as a spectacle with sadistic and sexual undertones for the pleasure of visual consumption. Historically, the gibbet was hanged and accordingly, it was portrayed vertically in various visual artwork. The museum's choice to display a prone gibbet underneath the masks is thus intriguing, but not new as it recalls the horizontal position of the gibbet in the Haunted Canada stamp released a few years prior. Although the prone gibbet is most likely displayed as such because of the condition of the artefact, this object placement generates a narrative that, in conjunction with the mask of La belle inconnue, evokes the figure of La Corriveau's sexually transgressive nature. More specifically, this part of the exhibition creates a subtle parallel between the gothic mode, sexual transgression, and sadomasochistic fantasy. Indeed, there is an uncanny 
resemblance between what seems to be executioner masks hanging directly above the gibbet and gimp masks. The latter, also known as bondage hoods, are an article of clothing worn during bondage, discipline (or domination), sadism, and masochism (BDSM) sexual role-play. More generally, there are some overall similarities between the executioner costume and the gimp costume, "a tout ensemble of black leather, buckles, zips, and lacing, entirely encasing the body" that "is the most efficacious in signifying this sexual transgression, horror, and risk-attachment" (Needham 151, italics in original). This triad—sexual transgression, horror, and risk-attachment—are all evident in the erotic subtext of the display. As we have seen, the gothic figure of La Corriveau has come to symbolize sexual transgression since many villagers, and later, readers of the various literary works on the legend of La Corriveau, believed La Corriveau to be a promiscuous woman. The museum exhibition plays on this depiction by transposing the gibbet and the legend into this fetishistic setting. In fact, executioners and gimps have sometimes been conflated in popular culture (Needham 152). As such, whether the masks evoke the hoods of executioners or gimps, the gibbet's prone state establishes a relationship of dominance and submission, wherein the former assumes the position of power with a mask that "functions to conceal identity and enable the fantasy role of domination" (Needham 155) over the helpless Corriveau figure, whose gibbet, in the context of BDSM, corresponds to a form of bondage that restrains her and prevents her from escaping. Finally, the mask of the mysterious woman on the left, and even the bones above the mask display, equally evoke a sadistic tearing apart of bodily limbs which may even be misinterpreted by some museum-goers as belonging to Marie-Josephte Corriveau. In contrast to Canada Post's English-Canadian interpretation of La Corriveau 
as a seductive witch roaming free, the Québécois museum, through its portrayal of $\mathrm{La}$ Corriveau as subordinate to her executioners, emphasizes her role as a victim, even as it sadomasochistically sensationalizes her transgressive and gothic dimensions. ${ }^{314}$

It has long been established that, through the act of curating, exhibitions generate narratives that guide visitors through the museum space and influence the ways in which they perceive exhibitions and displayed objects. In analyzing museum narratives, Rhiannon Mason argues that a textual approach "involves reading the object of analysis like a text for its narrative structures and strategies" (26). Such reading incorporates the analysis of space, object placement, relationship between objects, lighting, labelling and other physical text, and sound (Mason 26). The techniques through which museums educate the public by disseminating knowledge have changed considerably over the years, becoming looser and less directive. John H. Falk et al. argue that in the past, "museum exhibition developers and programmers often limit[ed] their thinking about learning to knowledge-based outcomes" (331). ${ }^{315}$ Increasingly, however, museum curation has shifted toward a "free-choice learning" approach wherein curators hope to stimulate interest among visitors and encourage them to pursue further research after their museum visit, rather than telling them what they ought to learn and bombarding them with an excessive amount of information and facts. As Falk et al. explain, museums are

\footnotetext{
314 This portrayal of La Corriveau as a submissive "victim" in BDSM role-play reflects popular misperceptions of the BDSM community. As Carol Truscott notes, "consensual sadomasochism has nothing to do with violence. Consensual sadomasochism is about safely enacting sexual fantasies with a consenting partner. Violence is the epitome of nonconsensuality, an act perpetrated by a predator on a victim" (30).

${ }^{315}$ Falk et al. do not provide a specific timeline. When discussing "recent" studies in cognitive and neurosciences, the source they cite dates back to 1994. As such, it would seem that the limited thinking about learning to knowledge-based outcomes refers to a time prior to 1994. Falk et al.'s chapter was published in A Companion to Museum Studies by Blackwell Pub. in 2006.
} 
"in the business of supporting individuals in their quest for knowledge and understanding — not the knowledge and understanding we might deem that an individual needs, but rather the knowledge and understanding that an individual decides that they need" (336).

The Musée de la civilisation's cultural mission brochure highlights the institution's enthusiasm for exactly this curatorial model of free-choice learning, noting that "Musées de la civilisation doesn't provide all the answers. It doesn't lay down fixed paths: it is instead a place where the individual, society, and the entire human species meet. It tackles the world's complexity with all its uncertainty and doubt" (Cultural Mission 8), and again that "they [the institutions] don't have all the answers-they're part of the process" (Cultural Mission 11) ${ }^{316}$ While the concept of free-choice learning empowers the museum visitor, its advantages are double-edged. Its reduction of narrative direction and its embrace of the role of knowledge resource provider for the self-directed learning of museum-goers opens the possibility of an interpretive free play that may revitalize old stereotypes relating to Québécois culture. Akin to a consumer's shopping experience, the museum's free-choice learning approach incites visitors to lean in for a closer view of an object of interest and read the information plaque when they so desire. All of these objects invite visitors to pursue their own research to learn more about Québec's history, even as they allow for a play of projection and fantasy.

\footnotetext{
316 "Musées" is plural since it refers to a museum complex that includes Musée de la place Royale, Musée de l'Amérique francophone, Maison historique Chevalier, Centre national de conservation et d'études sur les collections, and Musée de la civilisation (Cultural Mission 3). My references to the Musée de la civilisation have only been about the institution listed last in the enumeration, not the museum complex.
} 
Overall, the "se perdre" section of the museum exhibition featuring La Corriveau's gibbet supports the play of fantasy and stereotype over the invitation to learn through its portrayal of Québec as a gothic, fetishized space. As I noted in Chapter Two, English Canadians were fascinated with French Canada and imagined it as a gothic space of otherness. In this instance, however, the Musée de la civilisation is a Québécois institution. Consequently, it does not seem likely that its curators possess a perception of Québécois as gothic others, nor does the museum have any obvious motive for portraying its own history as a shameful past that must be forgotten. Nonetheless, "se perdre" displays various objects pertaining to crime, demonstrates a fascination with taboo subjects, and courts sensationalism by providing very little information about these objects. Out of the ten objects I enumerated - that is to say, the gibbet and its surrounding objects - only two are supplemented with some form of brief description. Such minimal interpretive guidance to such sensationalistic material undoubtedly reflects a considered institutional commitment to "free-choice learning" as a principle of curation, but the museum's status as a commercial institution surely plays a role in choices around curation and display. Set in the heart of Old Québec, the museum is at the centre of the city's touristic area; should it wish to attract tourists, it must be an entertaining place that caters to Québécois residents and tourists alike, and like many sites of cultural tourism, it seems to have at least selectively embraced the principle that it must concede to a certain degree of self-commodification if it wishes to be economically profitable. Alexis Celeste Bunten broadly defines self-commodification as "a set of beliefs and practices in which an individual chooses to construct a marketable identity product while striving to avoid alienating him- or herself" (381). Although her case study concerns "Native tour guide[s] 
... for Sitka Tribe of Alaska's subsidiary business, Tribal Tours" (Bunten 381), she notes that this process of self-commodification can be applied to "any group of subaltern people who choose to display themselves for pay to members of a dominant society" (382). Without using the term self-exoticization, Erik Cohen describes a similar phenomenon he calls "staged authenticity." Drawing on Daniel J. Boorstin, Cohen writes, "as cultural products lose their meaning for the locals, and as the need to present the tourist with ever more spectacular, exotic and titillating attractions grows ..., contrived cultural products are increasingly 'staged' for tourists and decorated so as to look authentic" (372). Its obvious difference from Sitka tour guides and "subaltern peoples" notwithstanding, the museum, too, is part of a tourism sector that, in addition to educating its visitors, promises to provide a form of cultural entertainment. Because the Musée de la civilisation needs to market itself predominantly to anglophone tourists, some degree of self-commodification seems necessary if it wishes to make a profit and compete with the other tourist attractions in Old Québec.

As Milena Ivanovic puts it, host communities "offer their cultures as consumable cultural products in order to gain economic benefits from tourists' consumption. They tend to commodify culture and adapt it to suit tourists' needs" (136). La Corriveau's gibbet is offered as such a consumable cultural product to visitors and tourists; it provides them with an exciting murder mystery that is buried in Québec's dark past. To facilitate its consumption, it is simultaneously packaged "according to consumers' desires" and "so as neither to offend nor overload the visitor with overwhelming amounts of information" (Bunten 386). The legend is also self-commodified to a certain extent by minimizing English-French conflicts at the heart of the court trials and more generally, at the heart of 
the legend — a strategy that seems calculated to avoid antagonizing the numerous anglophone tourists that visit Québec City. The only mentions of politics in the exhibition of the gibbet are that Marie-Josephte's "remains were exposed in a metal cage, a gibbet, according to English custom" and that "the Murray Administration seemingly wanted to make an example of her and instill fear in the inhabitants of Côte-du-Sud region, who resisted the British conquerors" ("Sortir de sa réserve"). These pieces of information point to the transition period in which the British military took control of New France but omit a thorough and immersive presentation of historical contexts from the French and British perspectives. Ironically, this process of self-commodification and minimalization of political tension precisely depends on and exploits the political malleability of the legend. Yet, it is safe to say that overall, the curation of the exhibition favours sensationalism over historical depth. The gibbet thus becomes an item that provides entertainment with its sensationalism, spotlight, and popular musical soundtrack, akin to the haunted ghost tours that superficially draw on history to create frightening evenings of entertainment for tourists.

Under these conditions, self-commodification is intrinsically connected to selfexoticization. In her study on Tribal Tours, Bunten asserts that "identifying themselves as the Other, tour guides demonstrate difference between themselves and their paying guests. Through self-exoticization as the Other, difference itself becomes a commodity that tourists can consume and potentially embody as part of their personhood" (387). "Sortir de sa réserve : 400 objets d'émotion," and especially the "se perdre" section, presents itself as an entertaining cultural other that anglophone tourists can metaphorically consume and embody (at a distance) for the duration of their visit. 
Considering the free-choice learning approach the museum embraces, it is telling that the museum would portray La Corriveau as a subdued victim. If the goal is to encourage selfdirected learning, an anglophone tourist uninterested in learning will remember $\mathrm{La}$ Corriveau as a dangerous woman who was killed by the authorities (a narrative that unsurprisingly glorifies law and order), whereas museum-goers interested in learning may discover, in conducting their own research, a subversive narrative in which British authorities falsely accused and executed La Corriveau. While their contexts of production are dissimilar, the stamp and the museum exhibition both largely strip the legend of its cultural function as a Québécois nationalist symbol; the Haunted Canada stamp offers an image of La Corriveau symbolizing a domesticated, indigenizing witch devoid of the cultural and political dimensions ascribed to the figure in the second wave of literary production pertaining to La Corriveau, and the museum offers an image of La Corriveau as a gothic, transgressive, and fetishistic fantasy that is also devoid of such cultural and political dimensions. In both cases, adapted and repurposed for commercial reasons, the legend is given the new cultural function of disseminating Québécois folklore to a wider audience through the very sensationalism that made La Corriveau interesting to nineteenth-century writers before their novels gave the figure heavily politicized symbolism.

\subsection{Brewing the Legend of La Corriveau at Le Bilboquet Microbrewery}

Similar to the analyses of museums and stamps, a close study of beers reveals how these items carefully engage in cultural politics. In spite of their self-evident commodification of culture, the beers celebrating the legend of La Corriveau- " $\mathrm{La}$ 
Corriveau" and "La Corriveau Impériale"—have the most potential for offering a subtle, subversive counter-discourse to the representation of Québécois culture within and outside Québec because of their wide distribution and sly reinvention of La Corriveau's gothic and nationalist associations. The legend of La Corriveau inspired the microbrewery Le Bilboquet in Saint-Hyacinthe, QC, to release two "folkluric" beers named after the legendary murderess. The first is an English oatmeal stout called "La Corriveau" and the second is an imperial stout called "La Corriveau Impériale." ${ }^{317}$ In what follows, I argue that in the case of beers- the most commercial of all the items this chapter explores - the tension between preserving and commodifying Québécois culture is at its most intense. I begin with an assessment of the two Québécois beers in terms of their cultural commodification, drawing on Julie M-A LeBlanc's findings on Unibroue's use of Québécois legends as a marketing strategy. Then, I analyze how Le Bilboquet employs neolocalism by exploiting Québécois regional lore, even as it keeps in mind diverse target consumers. "La Corriveau" and "La Corriveau Impériale" tap into a selfexoticized gothic narrative to appeal to Canadian and international consumers. At the same time, however, as items of Québécois cultural production, the beers encourage the local consumption of these products and offer a subtle nationalist narrative to those familiar with the legend. In other words, Le Bilboquet's use of La Corriveau's lore to market these two beers inside and outside Québec draws on the legend's malleability to present La Corriveau as a sensational gothic story for Canadian and international consumers, all the while subtly revisiting the cultural and feminist politics that were at

\footnotetext{
317 The production of "La Corriveau" and "La Corriveau Impériale" began in 1999 and 2013 respectively (Ferland and Corriveau 325-26).
} 
play in the post-1960 nationalist Québécois discourses for a more cognizant, and likely Québécois, audience.

Whether or not they are beer aficionados, many Québécois are familiar with the brewing company Unibroue, which produces beers that promote Québécois gothic folklore. The label of "La Maudite," for instance, features the flying canoe from the legend of la chasse-galerie, and "Ephémère," a limited-edition beer that changes flavours regularly (from "Ephémère bleuet" to "Ephémère canneberge," and so on) and reflects the ephemeral nature of the will-o'-the-wisps that figure on its labels. In her study of Unibroue and Québécois culture, LeBlanc explains that in the brewing industry, using cultural codes to convey messages to target markets is pervasive_- beer labelling and advertisements are carefully crafted to ensure brand loyalty. While large-scale brewers focus on global markets to sell their products, microbrewers and craft-brewers master the art of appealing to smaller, local, and regional markets by using specific shared cultural traits and recognizable elements of culture and folklore to sell "terroir" products. (47) In other words, Unibroue exploits Québécois folk narratives and heroes, marketing them successfully to gain a loyal and local customer base (LeBlanc 47). Unibroue employs gothic folk narratives and heroes in particular, suggesting a reinvention of Québécois gothic into a popular discourse of heroism and cultural pride for Québécois beer enthusiasts, especially as such discourse reflects Québécois identity. LeBlanc asserts that "folklore branding is not only integral to the way in which Unibroue markets its beers but also vital in how people choose to be represented through a product, how they identify and engage with it" (54). While LeBlanc specifically examines Unibroue and Québec, the 
idea of exploiting regional folk narratives and heroes more prominently exemplifies neolocalism.

Neolocalism refers to "a conscious effort on the part of people to pursue 'local' things" and "serves to connect these people to a particular place" (Mathews and Patton 277). It is an ideal marketing strategy for microbreweries. Adam J. Mathews and Matthew T. Patton explain that microbreweries' small size, limited production, and reduced geographic extent of distribution naturally lend itself to an attachment to specific place and connection with the local community. Local flavor is imparted not only in the beer itself, but also in the brewery and beer names, on the bottles and boxes as graphics/images, historic photographs, in company logos ... and even through large-scale ultralocal maps. (277)

As typically small, locally owned businesses, microbreweries seek to distinguish themselves through the production of "boldly flavored beers coupled with a defiantly independent spirit" (Oliver, "Craft Brewing" 271). Indeed, the rise of microbreweries coincides with the commodification of folklore and the emergence of folklore-themed beers such as those of Unibroue. Mathews and Patton specify that the rise in microbreweries was a result of "an increasing beer consumer desire to seek 'local' experiences" and that microbrewers have knowingly exploited the notion of "'specific' place marketing" to affirm their attachment to locality (277). Similarly, Joe Wiebe argues that "by linking beer with the local food scene—-something wineries thought to do a long 
time ago — craft brewers started to connect with vast new markets" (4). ${ }^{318}$ Le Bilboquet produces a wide range of products, from honey scotch ales to eisbocks and IPAs. La Corriveau is the only beer produced by Le Bilboquet that was evidently inspired by a Québécois folk legend, which consequently makes it the microbrewery’s staple of Québécois neolocalism. Other noteworthy beers of theirs that are not locally focused but that draw on Canadian and Indigenous cultures include the Billy Bishop Double IPA (featuring Billy Bishop in front of a plane) and the Peau d'ours American IPA (featuring two Indigenous people wearing headdress and carrying canoe paddles and blankets).

Although neolocal beers are certainly attractive to locals who recognize the images or stories on the beer labels, they are also attractive to international consumers. LeBlanc argues that "by targeting regional lore as part of a marketing strategy, Unibroue piqued international interest while promoting folklore in Québec" (54). Mathews and Patton elaborate on the international interest in regional lore, claiming that for non-local consumers, there is "an intrigue factor associated with local names and idioms that le[a]d outsiders to inquire and learn from locals about these instances" (278). This intrigue factor resembles free-choice learning in that both aim to stimulate the curiosity of a consumer who might then feel compelled to conduct a quick online search after drinking a beer or seeing a museum exhibition. In contrast to the limited accessibility of visitor

\footnotetext{
${ }^{318}$ Québec in particular "is home to some of the most creative and talented brewers in the country" and "there are breweries quite literally from one end of the province to the other, producing a far wider array of styles than breweries elsewhere in Canada" (Rubin 213). Josh Rubin argues that Québec has an astounding beer scene because "Quebecers have a greater openness to exploring good food and beverage than other Canadians, partly thanks to the French cultural influence in that province" (213). Moreover, in Québec, beers are easily available in numerous grocery stores, corner stores, and branches of the Société des alcools du Québec - better known as the SAQ stores. Since breweries can sell small batches to grocery stores and corner stores rather than only supplying SAQ stores with massive batches, they have the possibility of experimenting and creating new products with minimal financial risk (Rubin 213).
} 
museum statistics, tracking international interest in beer is much easier with websites that publish consumer reviews. For instance, ratebeer.com shows people drinking and reviewing "La Corriveau" and "La Corriveau Impériale" world-wide. In addition to places within Canada and outside Québec such as the Great Toronto Area, Fort McMurray, Edmonton, Halifax, and Vancouver, there are consumers in Spain, France, Germany, Poland, Latvia, Netherlands, Denmark, Belgium, United States, Turkey, Greece, Finland, Sweden, Italy, Czech Republic, Japan, Venezuela, and Ukraine ("Le Bilboquet La Corriveau"; "Le Bilboquet La Corriveau Impériale (Bourbon)”). While Canadians could buy Haunted Canada stamps and send them around the world, the beers make the legend more accessible to non-Canadians, who can directly purchase and consume the beers from their respective countries.

Interestingly, in the grocery stores I have visited, the "La Corriveau" English oatmeal stout does not provide any detail or description on the bottle label. ${ }^{319}$ However, in accordance with images found on beer-rating websites and search engines more generally, Le Bilboquet produces two different bottle labels, placing the title "La Corriveau" at different places and using either a fully black or black and red background. Both labels depict the same image of La Corriveau but only one provides an English and French description of the legend and the beer. As such, information regarding the legend of La Corriveau is widely disseminated as national and international consumers learn about the legend through the label of the English oatmeal stout, which briefly describes the figure as a legendary murderess who was hanged from the gallows (the label of the

\footnotetext{
${ }^{319}$ I have yet to find "La Corriveau Impériale." This special edition beer only appears around November or December.
} 
imperial stout does not offer this information). Considering the neolocal approach Le Bilboquet employs, it is surprising that the labels do not mention La Corriveau as being a Québécois legend. Nevertheless, the microbrewery's name and address give consumers a sense of the legend's provenance.

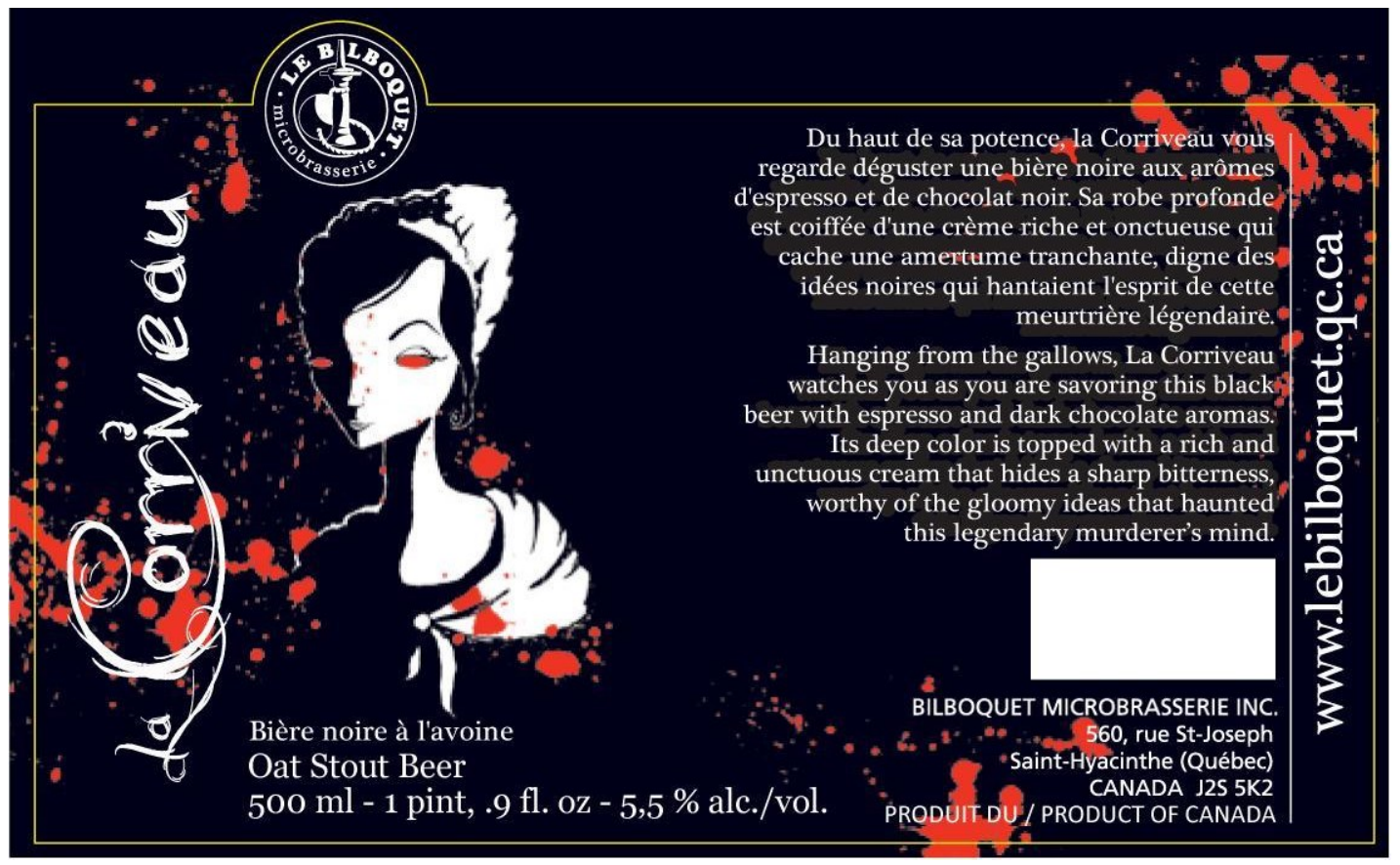

Illustration 8 “La Corriveau” Beer Label with Description 


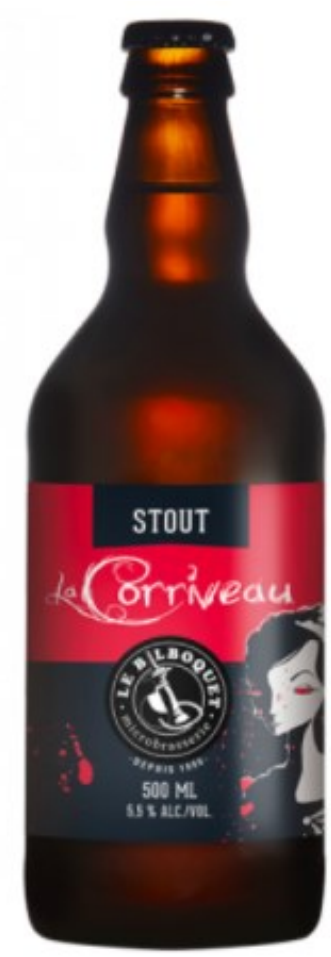

\section{Illustration 9 “La Corriveau” Beer Label without Description}

A label's main function as a marketing device is to attract the eye of a potential consumer. If one of the main goals in commodifying the figure of La Corriveau is financial profit, then logic dictates that she ought to be presented as an attractive woman. Such is the case with the Haunted Canada stamp wherein she is depicted as a beautiful, red-haired witch, and with the museum exhibition wherein La Corriveau is imagined by means of the iron gibbet, which is presented as part of a perverse BDSM fantasy. These iterations of La Corriveau, recalling Hébert's Ludivine and Lessard's Marie-Joseph, present her as a temptress figure. In the case of "La Corriveau" and "La Corriveau Impériale," the figure's attractive features encourage consumers to let themselves be tempted to drink the Corriveau beers. The sexualization of women in the beer industry is common. Beer marketing reaffirms beer consumption and participation in beer culture as a male-dominated sphere (Tyma 19). Adam W. Tyma explains that in beer marketing, 
"women are more often than not cast as nonbeer drinkers and, instead, objectified as sex objects" (19). The examples on which Tyma draws are overwhelming:

beers with names like Flying Dog's "Raging Bitch" and "Pearl Necklace," and Clown Shoes" "Tramp Stamp" focus on stereotyping and sexualizing women. Names and labels such as Pig Minds" "PD" (or "panty drop") ale series, which features a brew kettle between the legs of a woman in a mini-skirt, cast women as the object of male sexual desire at the expense of their own agency. (19)

The artwork on the beer label designs emphasizes the figure of La Corriveau's conventionally feminine sexual desirability. In black and white with a splash of red colour on the English oatmeal stout bottle, the three-quarter view of La Corriveau's bust is drawn in simple lines. There is little detail, as half of the image is hidden in the shadows. The other half shows La Corriveau dressed in a female peasant's clothing. The gothic, stylized drawings - minimalist, visual representations that detail the important elements of an image — emphasize La Corriveau's red eyes, bonnet, and shawl, the latter being articles of clothing more commonly worn by women. "La Corriveau Impériale" is even more detailed and feminine as the label describes the woman as having a "noble reputation," which signals how the figure also transgresses class distinctions by wearing a fancy feathered hat, pearl jewelry, and waves a paper fan. As we saw in Chapters Three and Four, Beaulieu's and Glover's literary representations of the figure of La Corriveau challenged her association with cis-gendered femininity (an allegory for Québec's colonial status). The Corriveau beers depart from this tradition by highlighting the figure's conventionally feminine physical appearance. Le Bilboquet's omission of the gibbet in the beers' artwork (in contrast to the significance of the gibbet in the Haunted 
Canada stamp and the museum exhibition) further highlights the figure's sexual desirability while downplaying her association to horror and murder.

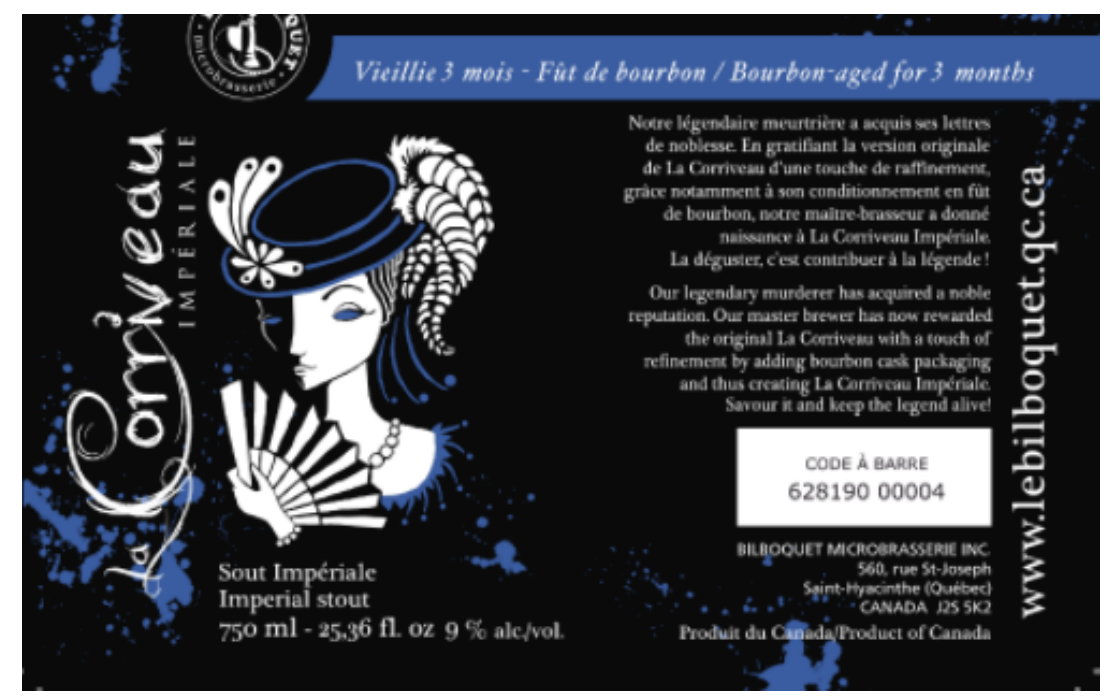

\section{Illustration 10 "La Corriveau Impériale” Beer Label}

In addition to the image, the descriptive text offers a conflation between beer consumption and sexual consummation. "La Corriveau" is described as follows: "sa robe profonde est coiffée d'une crème riche et onctueuse" ("La Corriveau"). 320 "Sa robe," usually in the sense of beer collar but translated as "deep colour" here, can be read as referring to both the beer and La Corriveau because of the undefined referent for the possessive determiner "sa" (her). This ambiguity in the French text suggests that the beer and its dark colour (evocative of La Corriveau's gothic history) are an imaginative proxy for La Corriveau herself as a sexual object. In this way, the text possesses an implicit sexual connotation and promotes a heteronormative act of consumption/consummation.

Complementing their portrayal of La Corriveau as an attractive woman, the two beers' types and styles distinctly target a masculine consumer base. There are strong

\footnotetext{
320 "Its deep colour is topped with a rich and unctuous cream" (translation provided on the beer label, italics in original).
} 
associations between alcoholic beverages and gender—specifically the performance of gender roles. In her examination of cultural stereotypes related to alcohol and alcohol consumption, Helana Darwin concludes that masculinity legitimizes "real" beer. She recapitulates Dan Conley's observations that children enjoy sweet flavours and might have an aversion to sour or bitter flavours. The latter are acquired tastes that children might enjoy as they mature over the years. There is consequently a problematic assumption, Darwin argues, that "the taste profile that is deemed legitimate is that which the palate must conquer in a masculinized quest of man versus nature. Flavors that are easy to appreciate, such as fruit, become constructed as culturally inferior while those that require cultivation and practice, such as IPA, become constructed as superior" (226). Basing themselves on Darwin's studies, Nathaniel G. Chapman et al. specify that "masculinity is associated with dark and/or domestic beers as well as whisky and bourbon while femininity is associated with more artisanal, fruity (and sugary) drinks such as sour and fruit beers, mixed cocktails, and wine" (300). Furthermore, "real beer" or "masculine beer is perceived to be more robust in flavor, darker in color, 'stronger' (i.e., has a higher $\mathrm{ABV}$ [alcohol by volume] than domestic beer), more aggressive, and, therefore, superior to lighter styles of beer" (Chapman et al. 304).

The Corriveau beers — oatmeal stout and imperial stout—unquestionably fall into the category of "masculine" beers. The description behind the English oatmeal stout beer reads, "pendue du haut de sa potence, la Corriveau vous regarde déguster une bière noire aux arômes d'expresso et de chocolat noir. Sa robe profonde est coiffée d'une crème riche et onctueuse qui cache une amertume tranchante digne des idées noires qui 
hantaient l'esprit de cette légendaire meurtrière" ("La Corriveau," italics mine). ${ }^{321}$ The description of the beer correlates with Darwin's and Chapman et al.'s findings in relation to "masculine" beer: the beer is of a dark colour and tastes bitter with its flavours of espresso and dark chocolate. On the other hand, "La Corriveau Impériale" provides little description regarding its colour and taste, only noting that "notre légendaire meurtrière a acquis ses lettres de noblesse. En gratifiant la version originale de La Corriveau d'une touche de raffinement, grâce notamment à son conditionnement en fût de bourbon, notre maître-brasseur a donné naissance à La Corriveau Impériale. La déguster, c'est contribuer à la légende!" ("La Corriveau Impériale"). ${ }^{322}$ This description is not exactly telling, but the beer's nine percent ABV falls well within Chapman et al.'s general description of "masculine" beers. ${ }^{323}$ Garrett Oliver asserts that "when used to describe beer, the word 'imperial' is now becoming widely used to mean 'stronger than usual"” ("Imperial" 47879). What is more, American craft brewers "started to append the word 'imperial' to any beer that mimicked an existing style, but boosted the alcohol level and often the hop bitterness as well" (Oliver, "Imperial" 479). "La Corriveau Impériale" is therefore a "masculine" alcoholic beverage based on its alcoholic strength, dark colour, and heightened bitter flavours. Coupled with a feminized and sexualized portrayal of La Corriveau, these stouts, as a "masculine" type of beer (according to the cultural

\footnotetext{
321 "Hanging from the gallows, La Corriveau watches you as you are savouring this black beer with espresso and dark chocolate aromas. Its deep colour is topped with a rich and unctuous cream that hides $a$ sharp bitterness worthy of the gloomy ideas that haunted this legendary murderer's mind" (translation provided on the beer label, italics mine).

322 "Our legendary murderer has acquired a noble reputation. Our master brewer has now rewarded the original La Corriveau with a touch of refinement by adding bourbon cask packaging and thus creating $\mathrm{La}$ Corriveau Impériale. Savour it and keep the legend alive!" (translation provided on the beer label).

${ }^{323}$ As a point of reference, both Molson Canadian and Labatt Blue have an ABV of 5\%. The "La Corriveau" English oatmeal stout has an ABV of 5.5\%.
} 
stereotype), indicate an attempt to target a masculine audience. The two beers attract consumers with a promise of strong and bitter flavours, and a promise that La Corriveau will return their gaze from her gallows while they consume her "robe profonde."

Le Bilboquet avoids bombarding its Canadian and international consumers with a highly politicized narrative, instead letting them enjoy an oversimplified and flirtatious gothic folk narrative of Québécois origin. However, the microbrewery succeeds at producing a multivalent narrative for various consumer groups since the same beers and labels can be read as reinventing Québécois gothic into an implicit nationalist marketing campaign for local consumers. I have explained how the two beers target consumers outside of Québec, but the larger issue at hand is how these commodities have been received inside of Québec and by those familiar with the legend of La Corriveau. Indeed, just as the Musée de la civilisation and the Haunted Canada postage stamps contributed to disseminating the legend of La Corriveau to a much larger audience, including nonQuébécois individuals, Unibroue and Le Bilboquet transmit folk culture inside and outside the province. However, given the target audience and social contexts of "hip," youthful beer consumption, Le Bilboquet is able to valorize provocation and bravado, and thus celebrate a sinister murderess, in ways that "official" institutions of cultural production like a conservative Crown corporation and a museum seem less disposed to do.

Peter van Lent argues that the use of folk images of the "typical Québecker" such as the logger, strongman, and folk hero Jos Montferrand was part of a project to reaffirm Québécois nationalism (339). He writes, “a popularization of the Quebec folk image does to some degree provide the province with an identity, the one thing that all Canadians 
seem to need most" (van Lent 339). These folk images, along with strong feelings of Québécois nationalism that directly correlated with self-perceptions of Québec's colonial condition, were used "to reengage and capture the emotional identity of a people," and this is "exactly what local producers of goods have done over the past few decades to sell their 'home-grown' and 'home-brewed' products" (LeBlanc 56). Furthermore, "the way folk groups respond to ideological branding, that is, branding appealing to a specific market, is representative of what constitutes their identity within that specific group and what bonds them together" (LeBlanc 57). If, as LeBlanc suggests, certain folk narratives and heroes are employed as a means of representing and transmitting a group's identity, and serve to consolidate a sense of belonging to such group (56), then Le Bilboquet did not market the figure of La Corriveau strictly for its association with crime and murder (as it is with the gibbet and the stamp), but for its symbolic function with respect to Québécois nationalism (also ironically like the stamp). The beers can thus be read as offering two distinct cultural messages. The first is that by tapping into a self-exoticizing process of neolocalism, Le Bilboquet employs a marketing strategy that commodifies Québécois culture, heightening its "intrigue factor” to appeal to Canadian and international consumers (an intrigue factor that recalls English Canada's original fascination with Québec as a gothic space). The second is that for Québécois beer drinkers, the beers' ideological branding may subversively consolidate a Québécois identity consisting of a resistant Québécois nationalism, recalling La Corriveau's nationalist and feminist re-imagining in Québécois literature in the second half of the twentieth century. 
As indicated on the "La Corriveau" label description, the figure's visibility at the top of the gallows and her gaze, directed at the stout drinkers, places her in a position of power in this symbolic hierarchy. The consumption of "La Corriveau" and "La Corriveau Impériale" is equated to beer drinkers consum(mat)ing this female, Québécois symbol of the nation. Through the purchase and consumption of the beers, they celebrate the murderess. In this manner, the beer versions of the legend of La Corriveau seem closely related to the sinister victory of the Corriveau witch on the postage stamp, but rather than serving an English-Canadian metanarrative of nationhood, she is closely re-aligned with her Québécois nationalist and feminist counterparts. Indeed, whereas the gibbet symbolically places La Corriveau in a position of submission with respect to the dominant executioner in the museum exhibition, here, the roles are reversed; $\mathrm{La}$ Corriveau is no longer a victim of British conquest, but the one conquering nations, one beer at a time.

Le Bilboquet's commodification of the legend offers locals an acceptable form of Québec's gothic othering. As we saw in Chapter Four, normative gender scripts typically treat violence and murder as the domain of men, while women are associated with care and nurture. Consequently, a violent woman is perceived as transgressing both criminal law and gender boundaries (Boyle 95). Lizzie Seal traces a brief history of criminology wherein scholars affirm that women who commit crimes are more likely to possess a masculine physical appearance. A prime example is Glover's androgenous protagonist who has a flat chest and tree trunks for ankles. However, Karen Boyle's argument contradicts that of Seal. Boyle asserts that "a woman who kills, or acts violently, is always visible as a woman — she is a damsel or angel of death, a black widow, a femme 
fatale, a female serial killer. These labels thus draw attention both to the criminal act and the gender transgression" (95, italics in original). As evidenced on both beer labels, La Corriveau is visibly a woman, and in highlighting her attractive physical appearance, Le Bilboquet markets her transgressive nature and depiction as a femme fatale. Consequently, the microbrewery subverts the process of Québec's self-exoticization by recuperating La Corriveau as a rebellious anti-heroine. Whereas the Musée de la civilisation is an institution of knowledge and consequently takes great care in its presentation of historical information and in avoiding any potential scandal pertaining to cultural and identity politics, Le Bilboquet can thoroughly dive into the legend and exploit any and all of its facets to maximize visibility and profit. The beers offer a means for Québec to play out its national identity reaffirmation project at home while downplaying it in the international arena. In creating a multivalent narrative that caters to various consumer groups, Le Bilboquet's "La Corriveau" and "La Corriveau Impériale" can appeal just as much to anti-colonial Québécois nationalists as they can to Canadian and international beer consumers interested in consuming exotic, gothicized alcoholic beverages. In the process, Le Bilboquet demonstrates how La Corriveau continues to function as highly flexible mediator of Québécois identity, even in the unlikeliest of places. 


\section{Chapter 6: Re-Indigenizing La Corriveau in Contemporary Québécois}

\section{Discourse}

This chapter continues in the vein of Chapters Three, Four, and Five wherein I interpreted the ambivalences surrounding the portrayals of the legend and figure of La Corriveau. Here, I examine two recent deployments of La Corriveau as complementary instances of the way “Québec's discourse betrays a form of strategic ambivalence toward settler colonialism” (Burelle 13). As Julie Burelle argues, “Québec's settler population have effectively recast themselves as natives to the land they occupy, using terms like Québécois de souche or Québécois pure-laine to differentiate the francophones with real or supposed ties to Nouvelle-France from newcomers" (13). Beaudin's film NouvelleFrance (2004) and Chartrand's trilogy of historical fantasy novels Le crépuscule des arcanes (2013-2016) both deploy the figure of La Corriveau in ways that supplement the Québécois settler-nationalist discourse of pure-laine identity (the myth of being "native" to the soil) with more conventional indigenizing tropes of settler belonging ("going native"). In both of these works — though with different degrees of self-reflexivity—La Corriveau is used as a figure that mediates settler indigenization within Québec in ways that register but also appropriate Indigenous resurgence, ensuring that the legend continues to be haunted in problematic ways by its history of associations with Indigenous peoples.

Reversing the disarticulation of La Corriveau from indigeneity during the period of Québécois nationalism that we traced in Chapter Three, recent reimaginings of La Corriveau as seen in Beaudin's and Chartrand's respective works reinvent, engage with, and in many ways perpetuate the discourse of identity in which La Corriveau is made to 
function as a nationalist Québécois figure whose image is strategically entangled with, and gains authority from, representations of Indigenous peoples. Current rearticulations of La Corriveau with Indigenous presence in Québec, I argue, register shifts in the visibility of Indigenous resistance to Québec as a settler colonial power-shifts that complicate and even challenge the more direct assertions of pure-laine nationalism that had been typical of La Corriveau's characterization in the nationalist theatre in the post1960s era. For instance, tensions between Indigenous peoples and settler Québécois society were widely publicized during the Mohawk Resistance at Kanesatake in 1990, a defining moment in the relationship between Québécois and Indigenous peoples at the end of the twentieth century that "further alienat[ed] the native community from Quebec society" (Dickinson and Young 374). ${ }^{324}$ This conflict between the Mohawk Resistance and the Sûreté du Québec (SQ), the Royal Canadian Mounted Police (RCMP), and the Canadian army demonstrated that while Québec “should have been uniquely positioned to empathize with the Mohawks given their self-fashioned and predominant narrative as a 'colonized' minority in Canada whose cultural and linguistic survival is threatened by the anglophone majority," it actually felt "profoundly threatened by Mohawk dissent and struggl[ed] to maintain its narrative as a colonized minority in the face of a Mohawk discourse that clearly aligned the French Québécois de souche with the perpetrators rather

\footnotetext{
324 The Mohawk Resistance at Kanesatake, also known as the Kanesatake Resistance and the Oka Crisis of 1990, was a land-claim dispute between the Mohawk and Oka that turned into a seventy-eight-day standoff between the Mohawk on the one hand, and the Sûreté du Québec (SQ), the Royal Canadian Mounted Police (RCMP), and the Canadian army on the other. While the Mohawk protest was triggered by the town's desire to expand a golf course and develop housing on a sacred Mohawk burial ground, this land dispute dates back to the eighteenth century when Philippe de Rigaud, Marquis de Vaudreuil, the governorgeneral of New France, granted Mohawk land to the Society of Priests of Saint-Sulpice with the promise that the land would benefit the Indigenous peoples. Since then, the Mohawk sought their land rights among British officials, the French seminary, and the Canadian government, in vain.
} 
than the victims of settler colonialism" (Burelle 8-9). After the failure of the Mohawk Resistance at Kanesatake, Québec "adopted a discourse that both downplays its colonial past, recasting it as almost benevolent, and brandishes the province's status as a colonized minority to advance Québec's national project” (Burelle 11).

In earlier periods, such a strategy had proceeded by aligning Québec with Indigenous peoples while simultaneously disavowing any role in the colonial violence to which Indigenous peoples were subjected. As we saw in Chapter Two, one of the features of de Gaspé's French-Canadian romantic nationalist project was a downplaying of French Canadians' settler colonial past; his work's association of French Canadians with Indigenous peoples and Scots was calculated to show that they are all colonized victims of the British military. At the same time, the novel's representation of the relationship between French Canadians and Indigenous peoples obscured the former's role in colonization and the dispossession of Indigenous lands. Kirby's The Golden Dog, while promoting an English-Canadian romantic nationalist project, similarly obscured the French Canadians' settler colonial past by asserting the similar deaths and "vanishing" of both French Canadians and Indigenous peoples.

In contrast to these nineteenth-century texts, Beaudin's film and Chartrand's trilogy directly engage with the discourse of Québec's settler colonial past, but they do so in ways that nonetheless reprise and reinvent the nineteenth-century evasions and mystifications of de Gaspé's and Kirby's depictions of indigenized French Canadians. Nouvelle-France organizes encounters between the figure of La Corriveau and the Innu community precisely to downplay Québec's colonial past. Presenting La Corriveau as a kind-hearted person who cannot do harm to the Innu, the film uncritically dramatizes $\mathrm{La}$ 
Corriveau's indigenization process and Québec's appropriation of the colonized status of Indigenous peoples. Chartrand's historical fantasy trilogy approaches this discourse of indigenization in more overtly critical ways, highlighting Québec's colonial past, while presenting a more explicit and nuanced perspective on the dispossession of Indigenous peoples and lands. Ultimately, however, Chartrand's protagonist "goes native" in order to become fully indigenized to the land. The death of La Corriveau in this trilogy signifies the real challenges this figure poses to revisionist treatments that would incorporate Indigenous resurgence, for the latter works directly against the Québécois discourse of colonized identity.

\subsection{Battling for Québécois Settler Nationalism in Nouvelle-France}

Titled Battle of the Brave in English, Beaudin's contemporary film NouvelleFrance (released in Québec in 2004 and elsewhere in 2005) constitutes a revival of La Corriveau's depiction as a gothic figure of otherness that is tied to the "vanishing Indian" trope- a discursive practice that had been interrupted by the disarticulation of these figures during the period when La Corriveau was first made to function as a figure of Québécois nationalism. The film initially began as a project about the legend of La Corriveau (Alioff 34). Gilles Carle, who directed Maria Chapdelaine (1982), and Richard Goudreau were developing a film on the legendary murderer but "the project fizzled ... when Goudreau began nudging the material in a different direction" (Alioff 34). Subsequently, "the story of La Corriveau became, in a script by Pierre Billon (co-author of the 2003 mega-hit Seraphin), a movie with few hints of the Gothic menace Carle had in mind" (Alioff 34). Far from being gothic, the end result of Nouvelle-France is a 
melodramatic historical romance in which La Corriveau herself is transformed into "Marie-Loup," a character who at once alludes to La Corriveau's history and nationalist function, while simultaneously serving as a bridge to identification with a legitimizing discourse of indigenized belonging. As my analysis of Marie-Loup's mediating nationalist role will show, the film offers a Québécois version of the English-Canadian indigenization narrative while simultaneously mythologizing the Québécois as a people colonized by English Canada. ${ }^{325}$ La Corriveau's identification with the Innu community in the film epitomizes a managerial discourse of indigenization wherein the Québécois simultaneously continue to deny their role as settler colonizers in the dispossession of Indigenous peoples and lands, and appropriate the position of the colonized. In what follows, I first contextualize this claim by providing a brief overview of the film's production and reception. Then, I look at the protagonist Marie-Loup and show how her characterization responds to and revises previous iterations of the figure of La Corriveau. Finally, I turn to Marie-Loup's identification with the Innu community and demonstrate how such an identification serves the film's ideological project of celebrating and consolidating Québécois settler nationalism for Québécois, Canadian, and international audiences.

As of 2004, Nouvelle-France was the most expensive Québécois film ever made, with a production cost of thirty million dollars. ${ }^{326}$ It was directed by Québécois director

\footnotetext{
325 Although Nouvelle-France is set in 1759 (and 1779), the filmmakers are informed by the present-day sociopolitical landscape. They make reference to "Québec" and the "Québécois" people in the "Making Of" documentary (a bonus feature on the Nouvelle-France DVD) and appear to weave together these identities into their filmic project. When discussing the film, the characters, and the plot, I use terms such as "French Canadian" and "New France." However, in making claims about the film and the filmmakers' ideologies, I use terms such as "Québec" and "Québécois."

${ }^{326}$ As a point of reference, the budget for Québécois films typically ranges between two to five million dollars and American films work with budgets between sixty and one hundred million dollars (Kelly).
} 
and screenwriter Jean Beaudin, whose best-known works include the film J.A. Martin, photographe (1977) and the television series Les filles de Caleb (1990-1991). Québécois actors Noémie Godin-Vigneau and David La Haye star in Nouvelle-France, but the cast noteworthily includes international celebrities such as Gérard Depardieu, Irène Jacob, Tim Roth, Colm Meany, and Jason Isaacs. Some critics compare this endeavour to a Québécois version of Titanic (1997) due to Céline Dion's involvement in the film (Kelly). Dion, a "vocal chameleon" whose "public image is equally pliable, a perfect screen upon which any national fantasy might be projected" (Hurley 142), sings the film's theme song, "Ma Nouvelle-France," which airs during the film's closing credits. The song was also featured in Céline Dion's album On ne change pas (2005). Beaudin directed the music video, which incorporates parts of the film and clips of Dion singing in a studio. $^{327}$

Nouvelle-France was marketed to international audiences and distributed in Canada, France, the United Kingdom, the United States, Spain, Germany, and Japan, among other countries (Bracken). Supporting the film's international ambitions was its large international cast as well as the expensive decision to create a multiple-language version film (MLV), meaning that several scenes were shot twice, once in French and once in English, with the same actors learning two scripts. Within this trans-linguistic international context, the filmmakers strove to impart the story of a battle the brave

\footnotetext{
${ }^{327}$ Luc Plamondon wrote the lyrics, and Patrick Doyle composed the music for "Ma Nouvelle-France" and the rest of the film soundtrack. In the "Making Of" bonus feature on the Nouvelle-France DVD, Plamondon states that he always imagined Dion singing the film's theme song. See Hurley's "National Affection: Céline Dion" (2014) for an examination of Dion's role as a dual symbol of québécité and other nationalities. Hurley also analyzes Dion through the woman-as-nation metaphor, a metaphor that was discussed in relation to La Corriveau in Chapters Three and Four.
} 
Québécois people fought against the British invaders, dramatizing a national fantasy that seeks to reaffirm Québécois nationalism on the international stage and to assert Québec's distinction from both France and Britain; unlike these two other nations, the film implies, Québec is rooted in and identical with "cette terre-là ... [avec] les amérindiens" (Nouvelle-France). ${ }^{328}$

Employing the British Conquest of 1760 as its historical backdrop, this filmic adaptation of the legend of La Corriveau centres on the budding romance between Marie “Marie-Loup” Carignan (played by Noémie Godin-Vigneau) and François Le Gardeur (played by David La Haye). Yet, the interplay between love and history here does not act as a metaphor for national alliance as it does in de Gaspé's, Kirby’s, and Glover's respective literary works. As the Battle of the Brave DVD box states, the film straightforwardly wants to showcase an "epic tale of great passion and sacrifice in a time of war" (Battle of the Brave). Marie-Loup and François are star-crossed lovers; in trying to save the colony of New France, and unknown to Marie-Loup, François goes to Switzerland and France to negotiate with powerful high-ranking individuals to gain their support in the war. Marie-Loup believes he abandoned her and marries Xavier Maillard (played by Sébastien Huberdeau), François's best friend. Still in love with François, however, she refuses to perform her conjugal duties and Maillard becomes frustrated, begins to drink heavily, and physically abuses her. One day, a villager discovers Maillard dead in his barn. A trial ensues, and Marie-Loup is declared guilty and sentenced to death by hanging in chains.

${ }^{328}$ That land. ... [with] the Indigenous peoples. 
Closely resembling the historical account of Marie-Josephte Corriveau's life as described by Lacourcière, this plot is nested within a frame narrative. The film actually begins with Marie-Loup's daughter France (played by Isabel Richer) at the deathbed of Curé Thomas Blondeau (played by Gérard Depardieu). ${ }^{329}$ In order to gain peace of mind before his death, Blondeau wants to know whether or not Marie-Loup killed her husband. Together, he and France reminisce about the life of Marie-Loup. Then, the final scene of the film returns to Curé Blondeau's deathbed, and through the voice of the older France, the audience learns that Maillard was about to rape France in the stable and that the latter killed him with an axe in self-defence. In the film's version of the legend of La Corriveau, Marie-Loup claims to have killed Maillard; she wishes to hide her daughter's actions to protect her. The film's structure is similar to that of Lessard's An Object of Conviction, which was published over a decade later, and one cannot help but wonder if Lessard had seen and was inspired by the film (there is no mention of this film in the acknowledgements section or epilogue of his work).

In trying to recreate the historical events of eighteenth-century New France, the filmmakers imagine a Corriveau figure that resembles her earlier, nineteenth-century literary counterparts. Specifically, the film is comparable to The Golden Dog because it draws on the corruption of the Ancien Régime and on the downfall of New France at the hands of Intendant Bigot. Marie-Loup is never called "La Corriveau" but is clearly modelled on Marie-Josephte Corriveau, as the filmmakers' account of the script's development and as the numerous similarities between their stories affirm; like La

\footnotetext{
${ }^{329}$ Isabel Richer plays the adult version of France. The young version is played by Juliette Gosselin, and she appears for the majority of the film.
} 
Corriveau, Marie-Loup is convicted of killing her second husband, goes on trial, and is sentenced to hanging in chains. The instability of naming practices among cultural producers who take up the legend of La Corriveau is itself part of the figure's history, and Marie-Loup's embodiment of La Corriveau might best be described as a present-day version of Kirby's version of La Corriveau, Dame Dodier. Like the villagers in The Golden Dog, those in Nouvelle-France believe the Corriveau figure to be a witch. Inquiring about a strange rumour she heard, France tells Marie-Loup, "il y a des gens en ville qui disent que t'es une sorcière" (Nouvelle-France). ${ }^{330}$ Marie-Loup's role as the town's medicine woman contributes to consolidating such rumours. Like Dame Dodier, Marie-Loup dabbles in medicine and "witchcraft." She prepares health remedies and claims she is able to make love potions and anti-aging products, which she sells for a high price to antagonists such as Angélique (played by Irène Jacob). Her preparations are based on her knowledge of various medicinal herbs and their uses, but her jokes, such as telling Angélique that she makes "love potions," exacerbate her reputation as a witch.

Furthermore, throughout the film, there are three religious women cloaked in black who appear to have a strong aversion to Marie-Loup, glaring at her whenever she walks past them. During Marie-Loup's trial toward the end of the film, one of the witnesses who is jealous of Marie-Loup for marrying Maillard (she plays a similar role to that of the historical Isabelle Sylvain) pretends to be strangled by a spell she imagines Marie-Loup to have cast upon her. The villagers in Kirby's and Beaudin's respective works also believe that La Corriveau interacts with the devil. In The Golden Dog, some villagers claim that Dame Dodier "talks with the Devil" (Kirby 370). In the film, France

330 "People in town say you're a witch" (translation provided by the film Battle of The Brave). 
cries and confesses to her mother that the villagers 'disent que tu m'as eue en couchant avec le diable" (Nouvelle-France). ${ }^{331}$ These similarities to Dame Dodier reconnect Marie-Loup to an old iteration of the Corriveau figure that previously established her as a malevolent witch.

Yet, even though Marie-Loup is portrayed as a gothicized other, the film reverses the meaning of this association. Just as her "love potions" are revealed to be nothing more than health wisdom, the three black-cloaked religious women who shun her (praying, crossing themselves, and kissing their rosaries) are themselves made to look like witches. Such ironic scenes reinforce the film's commitment to constructing MarieLoup as a misunderstood heroine-in this case, by showing that the characters who most closely resemble witches are the very ones who other Marie-Loup as a witch. This critique of the construction of Marie-Loup as a gothic other exemplifies how Marie-Loup is made to retain but modify not only the nineteenth-century images of La Corriveau as a witch, but also the mid- to late-twentieth-century feminist and nationalist refashionings of these images into political allegories, as examined in Chapter Three. As one of the filmmakers claims, "pour moi, c'était évident que Noémie [Godin-Vigneau] c'était la terre. Et en quelque part, Marie-Loup c'est le Québec, c'est cette terre-là" (NouvelleFrance, italics mine). ${ }^{332}$ This metaphor serves as a mythologizing narrative wherein Marie-Loup, as an allegory for Québec, rightfully belongs on the land; she is the land. In other words, rather than consolidate English-Canadian romantic nationalism as she did in her role as a gothicized figure of otherness in Chapter Two, Marie-Loup upholds

\footnotetext{
331 "They say you slept with the devil to have me" (translation provided by the film Battle of The Brave).

${ }^{332}$ For me, it was obvious that Noémie [Godin-Vigneau] was the earth. In some ways, Marie-Loup is Québec; she's that land (italics mine).
} 
Québécois nationalism in ways that recall but strategically modify Beaulieu's and Hébert's Corriveau figures. Instead of challenging Québec's colonial condition and subordination to English Canada, as Beaulieu's and Hébert's Corriveau figures had done, the filmmakers employ the legend of La Corriveau in a project that, in recounting "la genèse de notre société" (David La Haye qtd. in M. Dumais), seeks to legitimize Québécois settler nationalism. ${ }^{333}$ Within the film's national allegory, as I argue below, Marie-Loup's death plays a special role, providing a symbolic resolution to the contradictions and ambivalences of Québécois settler nationalism. On the one hand, Marie-Loup's death at the end of the film represents, as it did in Kirby's novel, the death of New France and the end of a dream of French sovereignty in North America.

Reimagined by the filmmakers into a Québécois nationalist symbol in the tradition of Beaulieu's and Hébert's interventions, Marie-Loup's death thus appears as a tragedy, even as it mythologizes a Québécois nationalist ideal. On the other hand, Marie-Loup's death is complicated by her identification with the film's Innu community, which paradoxically links her death to the success of Québec's settler indigenization project. In other words, Nouvelle-France orchestrates an equivalence between Marie-Loup and the Innu community in order to consolidate the Québécois settler indigenization narrative.

Like her nineteenth-century counterparts, then, Marie-Loup is a composite figure that embodies more than French-Canadian culture. Although officially French-Canadian, the film systematically identifies Marie-Loup with Indigenous peoples and cultures, virtually transforming her into a version of the Indigenous other of the settler colonial state. When François is injured, for instance, Marie-Loup is shown caring for him by

${ }^{333}$ The genesis of our society. 
placing a cool, damp washcloth on his forehead. In a defining moment of substitution, the close-up on Marie-Loup's face immediately disappears, only to be replaced with that of the Innu who is actually treating François's wounds. This match cut transition that equates her with the Innu is at once continuous with, but also more pronounced than, Kirby's nineteenth-century presentation of Dame Dodier "crouching" and "gliding" like a spectral Indigenous woman. The "Making Of” bonus material on the Nouvelle-France DVD (not available on the Battle of the Brave DVD) reinforces this connection with a match cut scene transitioning from a close-up of Marie-Loup's face to Innu children running in the forest. Tellingly, one of the filmmakers' claim that "Marie-Loup c'est le Québec, c'est cette terre-là" is succeeded by the following words: "alors, quand on la regarde, c'est évident qu'on retrouve toutes ces couleurs-là dans la nature. C'est la même chose pour les amérindiens" (Nouvelle-France). ${ }^{334}$ This comparison between Marie-Loup and Indigenous peoples is also explicitly brought up in the film. When talking to France, a young Innu named Acoona (portrayed by Bianca Gervais) confirms Marie-Loup’s symbolically freighted acceptance into the Innu community: "la vieille Matawa dit que ta mère a la peau d'un visage pâle et le cœur d'un Innu!" (Nouvelle-France). ${ }^{335}$

Coupled with Marie-Loup's identification with the Innu is the sympathy she expresses toward them. At the outset, the film distinguishes Marie-Loup from other

\footnotetext{
${ }^{334}$ Marie-Loup is Québec; she's that land. ... so, when we look at her, it's obvious that we see in her all of the colours of nature. It's the same thing with Indigenous peoples.

335 “Old Matawa says your mother has the skin of a paleface, and the heart of an Innu!" (translation provided by the film Battle of the Brave). As a side note, Bianca Gervais is a non-Indigenous actress portraying an Indigenous character. In 2020, her new role as Rosalie "Rosa" in Escouade 99, Patrick Huard's Québécois adaptation of Brooklyn Nine-Nine, generated controversy. Melissa Fumero, who plays the Latina Amy Santiago in the original American television series, criticized the producers of Escouade 99 for casting two white actresses-Mylène Mackay and Gervais - to play her character and that of the Latina Rosa Diaz respectively.
} 
villagers through her treatment of Indigenous individuals; she wants to protect and care for the Innu community. In one of the first scenes, Acoona runs through the town in hope of escaping a French soldier who wants to rape her. Marie-Loup blocks the soldier's way and slaps him on the face. Subsequently, she applies ointment to Acoona's foot, which she hurt stepping on broken shards of glass during the pursuit. During this time, MarieLoup converses with an elder Innu woman and asserts that she views Acoona as her own daughter. When the Innu exclaims, “ce n'est pas ta fille," Marie-Loup responds, "qui a dit ça? Elle l'est autant que France" (Nouvelle-France). ${ }^{336}$ Marie-Loup's desire to protect Acoona echoes her desire to protect France and shows how she treats both her adopted and biological daughters equally. This scene is fundamental in establishing Marie-Loup's relationship with the Innu community. The audience learns that Marie-Loup and her biological daughter France both speak Innu-aimun fluently as they can hold lengthy conversations with the Innu on a variety of subjects. Indeed, François, too, is presented as a benevolent protagonist with a similar affinity for the Innu. He used to be a trapper and lived with them before returning to town after the death of his father. He has many Innu friends and can also speak Innu-aimun, which explains why he is immediately attracted to Marie-Loup when he witnesses her protecting Acoona. Ultimately, though, it is MarieLoup's association with the Indigenous community—specifically her identification with and sympathy toward the Innu — that legitimizes her indigenization, and by extension, legitimizes the indigenization of the Québécois nation.

\footnotetext{
336 “Acoona's not your daughter. ... who says? She's no less my daughter than France" (translation provided by the film Battle of The Brave).
} 
Given the film's indigenizing subtext in which Marie-Loup and François are kindhearted (and tellingly paternalistic) settlers who respect, defend, and even identify with the Innu, any danger or calamity threatening the Innu community must come from the film's antagonists, namely the corrupt French soldiers, racist villagers, English soldiers, and "noble" intellectuals in Europe. For example, the French soldiers who work for Intendant Bigot (who, like the Bigot character in The Golden Dog, symbolizes the corrupt Ancien Régime) are only interested in baptizing or raping the Innu. In fact, when MarieLoup pulls the French soldier off Acoona, she shames him in his desire to baptize Acoona with his "saint chrême" (chrism), a religious pun that simultaneously evokes ejaculation (it sounds like "sainte crème") and the oily mixture a priest rubs on one's forehead during baptism. Marie-Loup's father (portrayed by Pierre Lebeau) refuses to break bread and sup with Acoona, whom he considers a "sauvage" without a soul because she is not baptized. Finally, when François goes to Geneva to request military assistance in the upcoming battle in New France, Voltaire tells him to visit other intellectuals and share his fascinating and entertaining stories about the "noble savages." This plot, which organizes the dramatis personae into a melodramatic opposition between "good" and "evil," is a strategically standard ideological gesture that encourages the viewers to align their views with those of the protagonists, transforming the antagonists into scapegoats with respect to the dispossession of Indigenous lands. This "purifying” strategy removes from MarieLoup, François, and their French-Canadian allies any blame for or responsibility in settler colonization and thus facilitates the Québécois settlers' indigenization process.

Unlike Dame Dodier, who murders the métisse Caroline in The Golden Dog, Marie-Loup is not shown to be complicit in the murder of Indigenous peoples. It is 
essential to her allegorical function as an innocent embodiment of settler Québec that her hands be clean so as to absolve the entire francophone nation from its role as colonizer, even as it appropriates the position of Indigenous peoples as victims of colonization. Thus, toward the middle of the film, British soldiers attack the town. They shoot cannonballs, one of which breaks a building structure that crumbles and traps Acoona, killing her in the process. As the film's Indigenous character with the most screen time, Acoona represents the Innu community and her death enacts the "vanishing Indian" trope. Her death symbolically allows French-Canadian settlers to become indigenized since the British cannonball is made culpable for Indigenous "vanishing." Marie-Loup's own death by execution is yet more symbolically complex. The ending of NouvelleFrance reveals Marie-Loup unhesitatingly accepting her fate; after explicitly claiming that she murdered Maillard and saying her final farewell to François, she is placed in her gibbet and hanged as the horse runs away, removing the stepping stool from beneath her feet. Marie-Loup's violent and tragic death asserts an equivalence between herself and Acoona that appropriates the colonized status of the Indigenous peoples. Like Acoona, she is an innocent victim of the British soldiers. At the same time, however, Marie-Loup paradoxically becomes a contradictory figure of Québécois settler colonial ambivalence. On the one hand, her ongoing identification with the Innu and her contrast with the film's corrupt and rapacious antagonists have made her into a purified symbol of settler Québec. On the other hand, her execution could also be read against the grain of the film's official narrative as specularizing symbolic punishment for Québec's national disavowal of colonial guilt, making her into another scapegoat figure. It is as though, in ways the film surely does not intend, Marie-Loup's symbolic "purity" cannot hold and slips away 
beneath her to reveal the historical violence of settlement it tries to forget. Consequently, the film's final image of Marie-Loup — La Corriveau—is that of a contradictory ideological figure who is able to purify the nation by purging it of this shameful past in two ways simultaneously: embodying both indigenized national myth and scapegoat at the same time.

Ultimately, the ending of Nouvelle-France resembles that of The Golden Dog wherein both the Indigenous peoples and French Canadians must perish to make way for the indigenization of the British soldiers. However, Beaudin's objective was not to praise the image of British soldiers in hope of consolidating the notion of a harmonious, unified Canadian nation-state. Brendan Kelly's interview with Beaudin reveals that the film director simply wanted to illustrate through Nouvelle-France a story "about the loss of Nouvelle-France and [how] it was the French that let us go ... The British were just doing their job. They attacked here just like they attacked elsewhere and took control of the territory. The French did absolutely nothing" (Beaudin qtd. in Kelly). The narrative elaborates on "the loss of what we were. We were conquered" (Beaudin qtd. in Kelly). As such, Beaudin's film does not oppose French Canadians to Indigenous peoples, or directly blame the British military for the fate of New France. Instead, the deaths of Acoona and Marie-Loup at the hands of the British soldiers fulfill the filmmakers' national fantasy: Nouvelle-France employs the figure of La Corriveau to indigenize Québécois settlement and to appropriate the colonized position of the now "vanished" Indigenous peoples so that Québec may justify its own mythology of being colonized by English Canada while France stood by and did nothing. 


\subsection{Going Native and Subverting a Genealogical Fantasy in Le crépuscule des arcanes}

Chartrand's historical fantasy novel L'ensorceleuse de Pointe-Lévy (2013) is the first installment of the trilogy Le crépuscule des arcanes and won the prix Aurore-Boréal, an annual prize given to the best Québécois works of science fiction or fantasy literature. The second and third installments, entitled La voyante des Trois-Rivières and Le sorcier de l'île d'Orléans, were published in 2015 and 2016 respectively. The trilogy is an exploration of Québécois history and culture set in an alternative version of North America in which characters use magic and in which a diverse cast of human, nonhuman, and supernatural figures are drawn principally from Indigenous and Québécois mythologies. The legend of La Corriveau is featured alongside other cultural legends such as the Wendigo, the Flying Canoe, the jacks mistigris (will-o'-the-wisps), and Indigenous Creation stories. Set in Lower Canada in 1849 and crafted as a multi-volume bildungsroman, the trilogy follows the French-Canadian protagonist Faustin Lamare's journey of self-discovery as he gradually masters magic, navigates the trilogy's story world, learns the secrets of his birth, and saves the world from destruction. A significant component of his adventure is his maturation as a hero, which is contingent upon leaving behind his juvenile self-indigenizing discourse and acknowledging his responsibility as a settler for the dispossession of Indigenous lands.

In the following pages, I interpret this bildungsroman as a progressive but flawed attempt to integrate the Québécois nationalist legend of La Corriveau into contemporary 
narratives of Indigenous resurgence through the genre of historical fantasy. ${ }^{337}$ At its most innovative, Chartrand's trilogy seeks to critique the settler discourse of a pure-laine genealogy as a claim to French-Canadian "indigeneity." It suggests that La Corriveau's persistent rebirth — she is literally resurrected multiple times in the trilogy — is a nationalist mystification that needs to be abandoned on the grounds that the pure-laine discourse of belonging with which she is associated does not adequately recognize the colonized position of Indigenous peoples within Québec. Accordingly, Chartrand's adaptation of the legend can be read as an implicit response to and, at least partially a rejection of, the Québécois nationalist symbolism that Beaulieu and Hébert ascribe to the figure, on the grounds that as a legitimizing symbol of origin, it is not as inclusive as it aims to be.

Similarly, the trilogy productively complicates Lessard's use of the Corriveau figure in An Object of Conviction, a work that outlines a fictionalized family history rooted in identification with Québécois history while neglecting the complexities of settler colonialism and Indigenous dispossession. Taking up the more overt discourses of settler indigenization and settler nationalism discussed in this chapter, Chartrand's trilogy makes an illuminating contrast to Nouvelle-France in its development of a critique of the indigenization narrative the film plays out naïvely and unreflectively. In the first installment, Chartrand casts Faustin as a naïve protagonist who symbolizes the indigenization of pure-laine French Canadians, using La Corriveau as a foundation to this

\footnotetext{
${ }^{337}$ Like Nouvelle-France, Chartrand's trilogy Le crépuscule des arcanes offers a complex historical interplay. In this section, I use the terms "Québec" and "Québécois" when referring to the present time and discussing Chartrand's attempts to address settler indigenization and Indigenous resurgence. When discussing characters or passages of the trilogy, I use the terms proper to the historical time period such as "New France," "Lower Canada," and "French Canadians."
} 
indigenizing discourse. Although he learns about Indigenous peoples' struggles against colonization from his Mi'kmaq friend Shaor'i, he employs a self-justifying discourse to disavow this dispossession. Unlike the film, which provides only a minor role to Acoona, Shaor'i has a more significant role as a mentor figure for Faustin as she persistently tries to educate him about colonization. While her words fall on deaf ears in the first novel, her knowledge and position are, by the end of the trilogy, integrated into Faustin's maturation and integral to his staving off of an imminent apocalypse, the threat of which organizes the trilogy's action. Faustin's growing sensitivity toward Indigenous peoples is clearly pedagogical and is meant to dramatize, in the allegorical register of fantasy, a transformation of settler colonizer consciousness that questions the celebratory spirit of settler nationalism.

Chartrand's trilogy is not, however, without flaws: although it succeeds in disentangling La Corriveau from her pure-laine indigenizing function and in showing Faustin's political maturation, there remains in this trilogy lingering tropes of settler indigenization. Its main shortcoming lies in casting a white French-Canadian settler as the ultimate saviour of the Indigenous peoples who succeeds in his quest to forestall an apocalypse (one wherein dark magic practitioners would take over the world) by symbolically renouncing his settler genealogy. As such, even though the narrative allegorically enacts a form of anti-colonial pedagogy in its education of the archetypal French-Canadian settler-hero, the narrative remains problematically limited by the tendency of the fantasy genre to celebrate messianic figures.

In L'ensorceleuse de Pointe-Lévy, Faustin is accompanied by François, Shaor'i, and the strongman Baptiste Lachapelle. Their quest consists of saving Rose Latulippe, 
who is kidnapped by a group of villains on the eve of Mardi Gras. Rose Latulippe (sometimes spelled Latulipe) is the main character in a Québécois folkloric tale known as la légende du Diable à la danse and la légende du beau danseur. Popularized by de Gaspé fils's Le chercheur de trésor : ou, L'influence d'un livre (1837), it is about a woman named Rose who, on the eve of Mardi Gras, dances with a stranger until midnight. This stranger turns out to be the Devil, who takes her to hell. In Chartrand's adaptation, Rose is a direct descendant of La Corriveau, the ensorceleuse de Pointe-Lévy, and will become the vessel used in La Corriveau's resurrection. Faustin and his friends must stop this resurrection as it would catalyze the restoration of an order of dark magic users and a battle between good and evil. This longstanding battle of "good" versus "dark" magic constitutes the overarching plot that spans the trilogy. On the one side, there are the théurgistes, French-Canadian settlers who practice good magic, and the arcanistes-médianistes, Indigenous peoples practicing “ancestral” magic —a balanced magic that is neither good nor bad. ${ }^{338}$ Among the arcanistes-médianistes, "certains étaient mohawk, d'autres wendat, d'autres encore attikamekw ou mi'gmak" but they “[ne] se [soucient pas] des différences de tribus" (Chartrand, L'ensorceleuse 91). While the arcaniste-médianistes are supposed to be neutral in this battle, they are allied with the théurgistes to some extent; shortly after the transition from the French to the British regime, these two groups agreed to a "traité de neutralité" (Chartrand, L'ensorceleuse

\footnotetext{
${ }^{338}$ In teaching Faustin about arcane magic, his uncle tells him that the surviving arcanistes chose to exile themselves in the New World. The English arcanistes settled in Salem but "n'avaient pas duré longtemps" [did not last long] whereas the French arcanistes settled at the Île d'Orléans and "étaient encore assez efficaces au début du siècle" [were still quite efficient at the beginning of the century] (Chartrand, L'ensorceleuse 94). The ones that are still alive are thus those of French descent. It is implied in the story that it is only after the Patriots' War that the group of arcanistes is split into théurgistes and goétistes.
} 
89). ${ }^{339}$ Within Faustin's group, his friend François Gauthier is a powerful théurgiste and Shaor'i is a Mi'kmaq warrior and arcaniste-médianiste who can transform into a snowy owl. On the other side of this battle are the goétistes, French Canadians who allied themselves with the British during the "Troubles de ' 38 et ' 39 " (Chartrand, L'ensorceleuse 213) and who practice dark magic. ${ }^{340}$ Since then, the order of goétistes has expanded to include British members.

Although La Corriveau only appears sporadically in the trilogy, she plays a key role in establishing Faustin's "authentic" French-Canadian identity and in foregrounding pure-laine identity as the central problem of the series. Shortly after her resurrection by an evil society of goétistes called l'Ordre du Stigma Diaboli, Marie-Josephte encounters Faustin, who is unaware that they share a familial bond. Saddened, she transfers her memories to Faustin in the hope that he will remember her. After she touches Faustin's temple, he sees flashbacks of the woman's childhood. He learns that in her first lifetime, Marie-Josephte encountered a French-Canadian necromancer named L’Étranger (also known as Le Bel Étranger), the leader of the Stigma Diaboli. He rapes her to secure his biological lineage. Through these series of flashbacks, Faustin discovers that he is their son.

Faustin's connection with Marie-Josephte evokes the discourse of authenticity and belonging that would legitimize his status as a pure-laine French Canadian. To use Burelle's words, the novel uses this genealogical connection to recast Faustin as a native to the land. Before meeting La Corriveau and seeing her memories, Faustin had been

\footnotetext{
339 Treaty of neutrality.

340 The "Troubles de '38 and '39" and this section of the novel clearly allude to the Patriots' War of 1837-1838. Chartrand erroneously gives 1838 and 1839 as the dates of the historical event.
} 
merely an orphan, adopted by the parish priest. Constituting his non-biological family were his “uncle," Curé Lamare; François, a young vicar and brother figure to Faustin; and the priest's servant, Madeleine, who Faustin sees as a mother figure. However, Faustin's newfound ancestry makes him a native son of the soil. Indeed, the first mention of La Corriveau in the novel actually details the figure's genealogical line. As La Corriveau's son, born in 1759, Faustin has been living on the land for eighty-nine years already prior to the beginning of the novel. Paradoxically, since Faustin inhabits a magically maintained sixteen-year-old body and grew up with Rose Latulippe-La Corriveau's great grand-daughter (born in 1829) - he is also symbolically a fourth-generation FrenchCanadian inhabitant of Lower Canada. Faustin's newfound connection to his father further substantiates this identity. When Faustin first hears about L'Étranger, he learns that "il avait un beau parler français, bien tourné, pas comme ceux de France mais peutêtre comme ... les instruits de Québec" (Chartrand, L'ensorceleuse 49). ${ }^{341}$ This comment subtly foregrounds a distinction between France and Québec, confirming L'Étranger's belonging to the latter group. Indeed, Faustin and his companions later find a portrait of L'Étranger that was painted by an inhabitant of New France in either 1670 or 1671 , suggesting that the necromancer was one of the first settlers of New France. By foregrounding the protagonist as the descendant of two Québécois folkloric figures (La Corriveau and L'Étranger, the Devil who prefigures in Rose Latulippe's legend), the trilogy thus begins in the realm of nationalist settler fantasy wherein Faustin can seemingly identify unproblematically as a pure-laine French Canadian. Moreover, as the

\footnotetext{
${ }^{341}$ He had a smooth French speech, articulate, not like those from France, but maybe like ... the scholars of Québec.
} 
son of an immortal, Faustin is born with a birth defect that makes him age at a

significantly slower rate than typical humans. This defect allows him to live for hundreds of years, making his indigenization all the more permanent as the Indigenous peoples of the region will inevitably die before him.

Like Marie-Loup's indigenization in Nouvelle-France, but in a more initially contemptuous register, Faustin's indigenizing discourse is premised on two components. The first, as we have seen, is the legitimization of Faustin's nativity to the land, established through his genealogical relationship with La Corriveau. The second is through Faustin's initial derision for Indigenous peoples (at least for those who are represented as "monkey"-like elves in the displacing idiom of fantasy) and his corresponding disavowal of the dispossession of Indigenous peoples in his own settler discourse, which advances the "vanishing Indian" trope. What makes Chartrand's revisiting of these tropes of settler colonial nationalism noteworthy, however, is the novels' commitment to problematizing them. Such an intervention is made especially evident by the trilogy's ambivalent characterization of La Corriveau herself. Although she functions in one sense as a conventional legitimizing figure within Faustin's indigenizing narrative, she is also tellingly presented as Faustin's antagonist and the obstacle to harmony within Lower Canada: within the plot of the first novel, Faustin must prevent her resurrection, or a chaotic battle between théurgistes and goétistes will ensue. $^{342}$ In L'ensorceleuse de Pointe-Lévy, Marie-Josephte's resurrection by the Stigma

\footnotetext{
${ }^{342}$ It is unclear how La Corriveau's resurrection would trigger this battle, but François suggests that La Corriveau is a powerful goétiste. Faustin understands that "Gamache souhaite fonder un nouvel Ordre avec cet Étranger immortal et cette sorcière Corriveau" (Chartrand, L'ensorceleuse 224). However, La Corriveau's concrete role in this context remains a mystery as François merely points out, "et si la Corriveau est rappelée à la vie..." (Chartrand, L'ensorceleuse 225), never ending this thought.
} 
Diaboli, who restores her to life using Rose Latulippe's corpse, is hardly an image of nationalistic celebration. The extreme ambivalence with which the novels characterize La Corriveau — as both legitimizing ancestor and a practitioner of "evil magic," a magical threat to the protagonist - make visible the (at least partly) critical nature of Chartrand's imaginative project.

Complementing Chartrand's ambivalent depiction of La Corriveau's legitimizing function is the trilogy's ideological re-education of the protagonist at the hands of his Mi'kmaq friend, Shaor'i, the main Indigenous voice in the fantasy series. The Mi'kmaq community chooses Shaor'i to fulfill the role of Executioner (Chartrand, L'ensorceleuse 93) and consequently, Faustin's team relies heavily on her for protection because she is a skilled assassin. However, her main ideological function in the trilogy is to act as Faustin's mentor. In several passages, Shaor'i imparts knowledge about Indigenous peoples to Faustin. For example, while navigating a secret river in a canoe, the group come across the mah oumet, also known as lutins (elves). Shaor'i teaches Faustin about this people that resembles small albino monkeys. When the group first sees the monkeylike creatures, Faustin is amazed that one of them fabricates a knife. Shaor'i does not see what is surprising about this act. Faustin replies, "bin, j'sais pas, ce sont des singes, non? Du moins ils en ont l'air" (Chartrand, L'ensorceleuse 165). ${ }^{343}$ Here, Chartrand clearly establishes through this passage a parallel between Indigenous peoples and the mah oumet. Faustin's comment—calling the people "monkeys"- dehumanizes the mah oumet and exposes his own unvoiced racism with respect to Indigenous peoples. Shaor'i sharply corrects Faustin and says, "ce sont de [sic] gens ... Ils forment un peuple. Nous sommes

\footnotetext{
${ }^{343}$ Well, I don't know, they're monkeys, no? At least they look like it.
} 
des invités, ici. Pourquoi les Blancs ont-ils tant de mal à comprendre ce genre de concept?" (Chartrand, L'ensorceleuse 165, italics in original). ${ }^{344}$ Unlike Faustin who is quick to dismiss this people as animals, Shaor'i views them as equals and understands their struggles against the white settlers who invaded their territory and decimated their population. She humanizes this "Indigenous" population by explaining to her companions the mah oumet's social structure, economic practices, and religion, and warns them about the dangers of bringing foreign items to their community since "ils en deviendront dépendants, comme nous avant eux" (Chartrand, L'ensorceleuse 170). ${ }^{345}$

In discussing the dispossession of lands belonging to the mah oumet, Shaor'i even sheds a tear when recounting to her companions the decline of the mah oumet population because of the lack of pine trees in their ideal mating environment. Faustin naïvely exclaims, “mais les pins repousseront! Ils grandiront!” and Shaor'i angrily retorts, “ah oui? ... Et dans combien de temps? Cent ans? Deux cents? Et tu crois que les mah oumet tiendront jusque-là?” (Chartrand, L'ensorceleuse 175). ${ }^{346}$ These conversations demonstrate Shaor'i's attempts to educate the others about the land's Indigenous populations; they also establish Faustin as a naïve protagonist who lacks an understanding of settlers' destructive actions. This passage is immediately followed by another wherein the group comes across komkwejwika'sikl, pan-Indigenous hieroglyphs that were traditionally used by all Indigenous peoples as a form of communication, but that are now lost, “dénaturés” because "des prêtres chrétiens en ont changé la

\footnotetext{
344 They are people ... They form a people. We are guests, here. Why do Whites have so much trouble understanding this kind of concept?

345 They will become dependent on them, like us before them.

${ }^{346}$ But the pine trees will grow again! They'll get bigger! ... oh yeah? ... And how long will that take? One hundred years? Two hundred? And you think the mah oumet will survive until then?
} 
signification, puis ç'a été la fin" (Chartrand, L'ensorceleuse 179). ${ }^{347}$ The sequence of these explanations further substantiates the parallel between the Indigenous peoples and the mah oumet, two peoples who lost a significant part of their cultures and traditions because of the colonizers and settlers. Solidifying the relationship between the mah oumet and Indigenous peoples is a ritual that bonds the two together. This ritual no longer occurs, but it was nevertheless "un honneur rarissime" in the past (Chartrand, L'ensorceleuse 365). ${ }^{348}$ As Shaor'i explains, “le lien qui unissait l'humain et le mah oumet était très puissant, peut-être davantage encore que celui qui unit des jumeaux" (Chartrand, L'ensorceleuse 365). ${ }^{349}$ As an Indigenous person who suffered similar experiences as the mah oumet, Shaor'i is in a position to sympathize with these people and to share their experiences with her peers in hope of raising settler colonial awareness about the violence and ongoing effects of colonization.

In the first book of the trilogy, after mulling over all that he has learned from Shaor'i concerning Indigenous peoples, Faustin responds with a rhetoric of denial. He thinks, and even admits to Shaor'i, that this devastation occurred many centuries in the past. He defends himself, asserting, “ce n’est pas moi qui ai répandu des maladies parmi ton peuple il y a deux cents ans. Pas plus que je n'ai tué quiconque de ta race. Je n'ai jamais tué personne. Ce n'est pas moi non plus qui ai décidé de vous chasser de vos terres ou de vous convertir de force au christianisme" (Chartrand, L'ensorceleuse 181). ${ }^{350}$

\footnotetext{
${ }^{347}$ Denaturalized ... Christian priests changed their signification, and that was the end of it.

${ }^{348}$ A rare honour.

${ }^{349}$ The bond between the human and the mah oumet was very powerful, perhaps even more so than the bond between twins.

${ }^{350} \mathrm{I}$ 'm not the one who spread diseases to your people two hundred years ago. I didn't kill anyone of your race, either. I've never killed anyone. I wasn't the one who decided to chase you people off your lands or convert you to Christianity by force, either.
} 
Shaor'i remains unmoved by Faustin's defensiveness, as if she has heard this speech numerous times, and Faustin cannot convince his Mi'kmaq mentor that anything will change in the future.

Faustin's evasion of political responsibility and refusal to grow beyond his prejudices in this passage are accentuated by the fact that, in his relationship with La Corriveau, he reveals himself to be fully capable of empathy, even across vast historical distances. Faustin wholeheartedly accepts the memories given to him by his resurrected mother whose consciousness now dwells in a receptacle corpse animated by dark magic and believes without question that he is Marie-Josephte's son. When Marie-Josephte transfers her memories to him, he even claims to become Marie-Josephte, seeing, smelling, and experiencing her childhood. The first time he relives Marie-Josephte's memories, he wonders, "Elle? Il était elle. Faustin n'existait plus. ... C'était désormais son passé" (Chartrand, L'ensorceleuse 323) ${ }^{351}$ When he understands these visions better, he explains that "il n'avait pas seulement vu l'enfance de Marie-Josephte mais aussi ressenti les émotions comme si elles avaient été les siennes. Plus encore. Il avait été Marie-Josephte au cours de ce rêve étrange" (Chartrand, L'ensorceleuse 333). ${ }^{352}$ Although he is confused at first, he does not hesitate to take this whole fantastic experience of transhistorical identification at face value. Through shared memories, in other words, Faustin symbolically becomes La Corriveau's double; like the split La Corriveau Blanche and La Corriveau Noire, as well as Ludivine and Rosalinde, here, Marie-Josephte creates a second self in Faustin.

\footnotetext{
${ }^{351}$ Her? He was her. Faustin no longer existed. ... This was henceforth his past.

${ }^{352}$ He didn't only see Marie-Josephte's childhood, but also felt the emotions as if they were his own. Even more so. He was Marie-Josephte during that strange dream.
} 
In contrast to the empathy and acceptance Faustin shows toward his mother, he is unwilling to understand Shaor'i's feelings of resentment toward settlers. When Faustin confronts Shaor'i during their journey because he wants them to have an amicable relationship, he says, “je n’aime pas être détesté. Ni par toi ni par personne. ... Je ne mérite pas ta haine" (Chartrand, L'ensorceleuse 182). ${ }^{353}$ Faustin's desire to avoid exposure to Shaor'i's anger (even her "hatred") strongly evokes the spectre of settler guilt and reveals his desire to imagine a colonial past wherein the relationship between settlers and Indigenous peoples is amiable, and wherein the French Canadians' role as colonizers is obscured. He vehemently denies his role as a settler in the colonization of Indigenous peoples, even after seeing the results first-hand-from the lack of pine trees to the lost knowledge of Indigenous magic and hieroglyphs. Faustin's refusal to acknowledge his role as a settler in Lower Canada thus exposes his early willingness to advance his own status within the region as a pure-laine who rightfully belongs on the land. In other words, his initial denial and self-justifying discourse around settler colonial history in Lower Canada are dramatized by the novel as elements of an expressly juvenile adherence to the reassuring fantasies of pure-laine indigenization.

Despite Faustin's failure to integrate Shaor'i's teachings in the first novel, Faustin's view of and relationship with Indigenous peoples increasingly evolve throughout the trilogy. The second novel is set two months after Faustin's first adventure, which ended in La Corriveau's self-sacrifice to banish L'Étranger and save Faustin. In La voyante des Trois-Rivières, the Stigma Diaboli resurrects La Corriveau once more. They hope to control her so that she may in turn free L'Étranger from his banishment. Faustin

\footnotetext{
${ }^{353}$ I don't like to be hated. Neither by you nor anyone. ... I don't deserve your hatred.
} 
and his companions regroup in order to track down this unknown child who serves as La Corriveau's new vessel and to foil the Stigma Diaboli's plans to bring back L'Étranger. As we have seen, Faustin's settler indigenizing discourse is based on his genealogical relationship with La Corriveau and on his complementary disavowal of Indigenous dispossession. Since this novel serves as a transition between the first and third installments of the trilogy, it is telling how it begins to dramatize a divergence between the two main components of Faustin's indigenization. Whereas Faustin's claim to the land continues to be formally legitimized through new iterations of La Corriveau, Faustin's perception of settler colonial legitimacy and his sometimes brittle relationship with Shaor'i both begin to change.

The first of these changes is that Faustin's acceptance of the pure-laine discourse of settler colonial belonging is complicated in the second novel by its pronounced gothic deformation, which is marked by the motifs of illegitimacy and incest. Previously, the figure of La Corriveau was employed as a means of legitimating Faustin's claim to the land, but in La voyante des Trois-Rivières, she is reborn in the body of Rose's illegitimate child. While the child's identity remains a secret for most of the novel, Faustin discovers at the very end that she is in fact his own daughter. Readers learn through a series of flashbacks that before the events of the first novel, Faustin and his great-niece Rose had sexual intercourse. ${ }^{354}$ Rose became pregnant and gave their child away. That child, Anne, was then kidnapped by L'Étranger's henchmen and she consequently became the second

\footnotetext{
354 The timeline for this event is unclear. In a discussion between Faustin, François, and Rose's mother, the latter claims that Rose was pregnant "l'année dernière" [last year] —in 1848, the same year as the events of the first novel (Chartrand, La voyante 44). However, other passages describe the child as a fouryear-old (Chartrand, La voyante 5, 34).
} 
vessel for La Corriveau when Rose, La Corriveau's first vessel, died. La Corriveau's persistent rebirth into the bodies of her female descendants - in short, her refusal to diecan be seen as a ghostly gothic trope that is "invoked as a way not only to affirm cultural legitimacy and longevity, but also to establish settler ancestors whose role, as Gothic spectres, would be a sustaining one" (Sugars, Canadian Gothic 110). This complex and perverse genealogical interplay casts a lurid critical light on Faustin's indigenization. La Corriveau's rebirth suggests a persistent narrative of settler indigenization because she refuses to "vanish" from the land. Moreover, her biological relationships with both Rose and Anne also signal the perpetuation of the Corriveau genealogy—a perpetuation secured by Faustin himself in his supernatural longevity and his role in conceiving Anne-and confirms that it will remain on the land for generations. The sheer gothic excess of this dramatization once again renders La Corriveau's legitimating function more sinister than "pure." As such, Chartrand's version of the figure is re-associated with her witch-like nineteenth-century literary counterparts and is actually rendered even more malevolent.

While La Corriveau's rebirth in the second novel continues, at least formally, to affirm Faustin's indigenization, he has no control over his genealogy. What Faustin does have control over, however, are his feelings about Indigenous dispossession. Indeed, as Faustin moves forward in his coming-of-age (literally, since the repercussions of a magical spell cause his body to mature from that of a sixteen-year-old boy to "un corps d'homme" (Chartrand, La voyante 192)), he carefully works through his views on colonization. ${ }^{355}$ He begins to question his role as a settler who has been denying the

${ }^{355}$ A man's body. 
reality of Indigenous peoples and their colonial struggles. At the beginning of La voyante des Trois-Rivières, for instance, Faustin recalls his meeting with the mah oumet and still feels uncomfortable. He has yet to ask serious questions about his people's role in the history of settler colonialism and continues to find the prospect of the mah oumet as a living people strange. However, as his group's new journey unfolds, he develops a more genuine friendship with Shaor'i. She teaches him how to fight, and in this process, they must connect spiritually and dance together, with Faustin intuitively matching every one of Shaor'i's steps. Numerous are the times afterward that Faustin would correct anyone calling her a "Sauvagesse" or "Indienne," affirming that she is Mi'kmaq and that she has a name. Later, when Faustin is separated from his group, he meets an otter-like creature called maymaygwashi. Immediately, he understands it to be an Indigenous individual like the mah oumet. He realizes that "cette bête n'était pas un animal. Tout comme les mah oumet, elle était... quelqu'un" (Chartrand, La voyante 314 ) and treats it with the respect he typically gives to human beings. ${ }^{356} \mathrm{He}$ and his friends also travel with a new mah oumet companion they nicknamed Ti-Jean and Faustin no longer shows signs of apprehension. Faustin's newfound appreciation and respect for these individuals and communities subtly dismantle the self-justifying discourse that legitimized his indigenization. Coupled with the consolidation of Faustin's connection to the land, his growing awareness of Indigenous dispossession begins to make possible a more thoroughgoing interrogation of his role as a settler.

Despite these impulses to complicate and even subvert the legitimizing and indigenizing narratives of settler colonialism in Lower Canada, the last installment, Le

356 This creature wasn't an animal. Like the mah oumet, it was ... someone. 
sorcier de l'île d'Orléans, reveals the paradoxical treatment of Indigenous peoples that has plagued the trilogy as a whole. In trying to make Faustin a protagonist that is truly sympathetic to Indigenous peoples, Chartrand inadvertently reproduces many of the indigenization narratives that he wishes to subvert. On the one hand, the heightened engagement with Indigenous cultures and histories succeeds in showing Faustin's political growth. Indeed, there are many instances in the last novel wherein Shaor'i tells Faustin stories about "les Cinq Nations," the mah oumet, the maymaygwashi, the history of the Mi'kmaq, as well Indigenous myths. Rather than interrupt defensively as he did in the first novel, Faustin listens carefully and now takes her words at face value. No longer questioning why this should concern him, Faustin acknowledges that Shaor'i's stories, which are vital to understanding the upcoming apocalyptic event, pre-date white settlement on the lands. He realizes that "ce que les Blancs connaissaient des Indiens remontait à l'arrivée de Cartier, de Champlain et de Maisonneuve. Les histoires évoquées par Shaor'i provenaient de beaucoup plus loin dans le temps" (Chartrand, Le sorcier 32). ${ }^{357}$ Furthermore, he develops a psychic connection with Shaor'i. Previously, Faustin could only hear Shaor'i's voice in his mind. In the last installment, this connection becomes bidirectional, and he can communicate with her to locate her presence or warn her of any imminent danger. Indeed, after the Indigenous Nadjaw (the Executioner before Shaor'i) casts a spell on Faustin, he must truly learn how to live like Shaor'i and other Indigenous shapeshifters. Nadjaw bestows upon Faustin the animal form of a fox. With Shaor'i's help, Faustin learns how to hone this power- to think, smell, and see like a fox.

\footnotetext{
${ }^{357}$ What the Whites knew about Indians dated back to the arrival of Cartier, of de Champlain, and of Maisonneuve. The stories Shaor'i evoked originated from much further back in time.
} 
Over time, this becomes a useful skill as he can transmogrify at will. This newfound ability unquestionably strengthens Faustin's bond with Shaor'i and signifies a more general merging of settler consciousness with Indigenous presence, epistemologies, and concerns.

As the protagonist, Faustin is the character who evolves the most, but his growth is matched by a shift in the overall narrative attitude toward Indigenous peoples and history as well. Reflecting Faustin's political growth, other characters are also increasingly respectful of Indigenous peoples. Readers learn the backstory of Nadjaw and her French-Canadian husband Louis-Olivier Gamache. These antagonists suddenly become sympathetic characters when Shaor'i explains that Nadjaw “n'acceptait pas de voir les siens adopter le mode de vie des Blancs jusqu'à oublier qui ils étaient. Puis, un jour, elle a rencontré ce sorcier roux [Gamache] qui craignait pour la disparition de sa langue, de sa culture et de sa magie face à l'envahisseur anglais" (Chartrand, Le sorcier 40). ${ }^{358}$ The mah oumet Ti-Jean, who lost his people as a result of the arcane magic war and of the deforestation that prevented them from mating, and Baptiste, who lost his eyesight in a battle against the Stigma Diaboli, enter a significantly symbolic symbiotic relationship; Ti-Jean is no longer alone and Baptiste can see through the eyes of the mah oumet. Through these unfolding events, Chartrand dramatizes his protagonist's evolution; he engages in more complex and sympathetic treatments of Indigenous peoples in his fiction via the growth of his protagonist and the optimistic generalization of the latter's transformed point of view.

\footnotetext{
${ }^{358}$ Didn't accept to see her people adopt the lifestyle of the Whites to the point of forgetting who they were. Then, one day, she met that red-haired sorcerer [Gamache] who feared the disappearance of his language, his culture, and his magic in the face of the English invader.
} 
Thus, unlike Nouvelle-France, the trilogy attempts seriously to problematize settler colonial indigenization, but in so doing, Chartrand routinely reverts to Indigenous stereotypes and indigenizing tropes. As a strong-headed woman and mentor, Shaor'i constantly challenges settlers' misperceptions of Indigenous peoples, but on multiple occasions she is represented as an "Indian maiden," "Indian warrior," and "ecological Indian" figure. Faustin, too, is problematically presented as "going native," as the foregoing account of his development of a psychic connection with Shaor'i and his receipt of "Indigenous" shape-shifting powers from Nadjaw all suggestively indicate. Like Marie-Loup, Faustin implicitly becomes an honorary Indigenous person as he learns the ancient spiritual battle dance with Shaor'i, and is even bestowed an animal form that is typically seen in the Indigenous arcanistes-médianistes. One of the most problematic moments of indigenization is when Faustin gathers soldiers to create an army to defeat L'Étranger. He discovers that Ti-Jean was not the last of the mah oumet and suddenly sees before him "des centaines. Des centaines de singes albinos couvraient le sol de la grande clairière" (Chartrand, Le sorcier 363). ${ }^{359}$ Their survival seems at first to be a rejection of the "vanishing Indian" motif that symbolizes ongoing Indigenous resistance. However, this passage is significantly undercut by Shaor'i's speech about Faustin's role in their survival. With his newfound teachings about the mah oumet, Faustin begs them not to participate in the war. He wants them to return home so that they may survive and repopulate over time. Yet, in a surprising turn of events, Shaor'i professes with great emotion that Faustin is their saviour. She tells him, "ils croient en toi," and admits that he

${ }^{359}$ Hundreds. Hundreds of albino monkeys covered the ground of the large clearing. 
gives "un sens à leur disparition" (Chartrand, Le sorcier 365). ${ }^{360}$ She continues by saying, “tu n'es qu'un pauvre imbécile! ... Tu ne vois pas que, sans toi, il ne leur reste plus qu'à attendre passivement l'extinction de leur espèce, au fur et à mesure que les grands pins seront abattus, sachant qu'il est déjà trop tard pour eux, que même en migrant ils ne seront plus jamais assez nombreux?" (Chartrand, Le sorcier 366). ${ }^{361}$ These words problematically make of Faustin the white saviour who must single-handedly prevent the death of the otherwise "vanishing" Indigenous peoples.

While Chartrand thus clumsily subverts Faustin's anti-colonial education in favor of a paternalistic narrative that makes Faustin a white savior and consequently undermines his maturation, the trilogy does succeed in critically undermining the other indigenizing narrative associated with La Corriveau. Despite the relative brevity of her appearances in each novel, her role is central to the trilogy's symbolic economy overall. Toward the end of Faustin's journey in the last installment, he once again encounters La Corriveau and realizes that during the last resurrection in Anne's body, La Corriveau lost her personality and the memories of her first lifetime. Now that La Corriveau is simply an evil being to whom Faustin no longer has any emotional attachment, Faustin is able to kill her in his quest to prevent the apocalypse. Indeed, the trilogy culminates in the severing of all of Faustin's family ties. His adoptive uncle Curé Lamare and his surrogate mother Madeleine die in the arcane magic war. In addition to killing La Corriveau (who is simultaneously his mother and his daughter), Faustin kills François (his adopted

\footnotetext{
360 They believe in you ... meaning to their disappearance.

361 You're nothing but a poor imbecile! ... Don't you see that without you, they have nothing left but to wait passively for the extinction of their species, gradually as the great pines are cut down, knowing that it's already too late for them, that even if they migrate they aren't sufficient in number?
} 
brother whose spirit was taken over by a goétiste) and his father L'Étranger.

Consequently, he has no blood family left. Moreover, in his final encounter with L'Étranger, Faustin performs a counter-curse that removes his own longevity. The backlash of the spell makes him age from his newly acquired "corps d'homme" into an old, weak man. He feels "ses forces l'abandonner. À quatre pattes sur le sol, il v[o]it ses bras et ses mains vieillir, leur peau se parcheminer et se couvrir de taches brunes" (Chartrand, Le sorcier 413). ${ }^{362}$ The loss of longevity and rapid aging suggests that Faustin will soon die. This spell disrupts Faustin's role as a long-standing pure-laine settler, in part, as it ends La Corriveau's biological heritage and any possibility of her being reborn.

In the end, La Corriveau's death symbolizes the disappearance of the settler "ghost" who "provide[s] historical antiquity" and "help[s] place settler descendants as secure 'inheritors' of the land" (Sugars, Canadian Gothic 109). This ultimate death also suggests the impossibility of reconciling the legend of La Corriveau with progressive narratives of Indigenous resurgence, even when such narratives appear in their more conventional, reactionary forms as the romantic settler wish to indigenize by "going native" or by assuming the role of white savior, as they do here. Indeed, in a paradoxical turn of events, Faustin no longer needs La Corriveau to indigenize him. Like Marie-Loup, Chartrand's Corriveau figure is a contradictory figure of Québécois settler colonial ambivalence. On the one hand, the beginning of the trilogy offers Marie-Josephte as a "purified" figure who sacrifices herself and offers L'Étranger as a scapegoat for the vices

\footnotetext{
${ }^{362}$ His strength abandoning him. On all fours on the ground, he sees his arms and hands age, the skin wrinkling and being covered with brown spots.
} 
and failures on the part of the French-Canadian population. On the other hand, the ending of the trilogy recuperates La Corriveau as that very scapegoat by imbuing her with gothic excess, presenting her as a grotesquely evil and incestuous figure who must die. While Marie-Loup's symbolic "purity" cannot hold and unravels to reveal French-Canadian colonial violence in Nouvelle-France, Faustin's new role as the messianic saviour of Indigenous peoples bypasses the need to preserve such "purity." In other words, now that Faustin is the acknowledged saviour of various Indigenous peoples such as the mah oumet, the maymaygwashi, and even Shaor'i, the third novel suggests that FrenchCanadian indigenization may be obtained by a route that avoids the gothic seductions of folk culture. Since he is accepted by all Indigenous peoples in the story, he no longer needs to retain his pure-laine status in order to establish a "legitimate" claim to the land. As such, Chartrand's trilogy reinvents settler colonial indigenization in Québec by abolishing La Corriveau; Faustin’s “maturation” rejects the legitimizing pure-laine discourse in favour of a recognition of Indigenous dispossession that paradoxically grants him a claim to the land, a claim that is legitimized not by identification with pure-laine French Canadians, but by identification with Indigenous peoples themselves. 


\section{Conclusion}

Chartrand's historical fantasy trilogy imagines La Corriveau being reborn generation after generation through a magical practice of resurrection. This image epitomizes the legend of La Corriveau, as the figure has been reborn numerous times over the centuries, every time embodying a new type of nationalism or some other ideal. My dissertation has argued that over the course of its many rebirths the figure of $\mathrm{La}$ Corriveau expresses and mediates conflicts between English and French Canada in both literary traditions. In studying the legend from a historiographic perspective, I have critically examined the intersecting and opposing political representations of $\mathrm{La}$ Corriveau over time to reveal how they promote national metanarratives and countermetanarratives in Québec and English Canada, as well as project Québec onto the world stage. As I have demonstrated, the legend has been a highly flexible and polyvalent signifier within bicultural debates and continues to reflect Québec and English Canada's evolving relationship, with each other as well as with Indigenous peoples and minority groups in Canada. In addition, I have shown that while the legend has mainly been resurrected by Québécois and English-Canadian authors in a desire to recuperate the figure for distinct national metanarratives in Québécois and English-Canadian literatures, it has also been explored by American and Franco-Ontarian writers, cultural institutions, and even microbreweries that employ La Corriveau for non-national purposes such as family narratives, creative writing projects on spirituality, and marketing.

As a dramatic instantiation of the tensions between the English officers and French-Canadian habitants and a defining moment in Québécois history—the Conquest of 1760 - the legend has been employed from the moment of its inception in the literary 
sphere as a national symbol. Marie-Josephte's first imaginative "resurrection" following her execution and the public display of her corpse in an iron gibbet in 1763 assumes a gothic form that would have a lasting impact on the figure's discursive legacy. Devoting two chapters of his novel Les anciens Canadiens to elaborating a story about a malevolent witch named La Corriveau who torments a man and demands that he bring her to the Île d'Orléans for a hellish celebration with the Devil and other fiendish creatures, de Gaspé establishes how La Corriveau could contribute to French-Canadian romantic nationalism when preserved as a legend of French Canada. This strategy remains in evidence today as the ongoing production of material on the legend of $\mathrm{La}$ Corriveau within Québec attests. As a gothic revenant, moreover, La Corriveau symbolizes, in de Gaspé's work, the French Canadians' refusal to forget the violence and devastation they experienced during the British defeat of New France. De Gaspé's portrayal of La Corriveau as a figure that identifies not only with French Canadians, but also with Scots and Indigenous peoples further suggests (problematically, of course) that they all occupy the same colonized position with respect to the British military. Meanwhile, as I argued, de Gaspé's social position in the French-Canadian aristocracy led his novel to implicitly, and most likely unwittingly, promote English-Canadian romantic nationalism by presenting La Corriveau as a tacitly assimilationist figure that wants to unite with hellish fiends representing British officers. Fourteen years after de Gaspé's novel, La Corriveau was born again, repurposed for a strictly English-Canadian nationalist project at Kirby's hands. In this version, La Corriveau retains some of the characteristics attributed to her by de Gaspé; she is still a witch-like figure identified with French Canadians and Indigenous peoples. However, The Golden Dog adds to this image 
the characterization of La Corriveau as a poisoner, as well as her identification with Acadians. In light of Kirby's loyalist sentiments and desire to see a harmonious and unified Canada, his narrative dramatizes in highly symbolic terms the destruction both of Indigenous peoples (as La Corriveau brutally stabs the métisse Caroline) and French Canadians (via La Corriveau's own execution) to "create," ironically, a terra nullius that the British officers could claim for themselves. Indisputably, de Gaspé's and Kirby's texts are the literary pillars of the legend and provided future cultural producers with a gothic basis for the imagining of La Corriveau in other nationalist contexts; while their projects were of the romantic nationalist variety, La Corriveau would come to epitomize not only the Québécois nationalism of the Quiet Revolution but the settler nationalism of a later period as well.

Following the development of a new Québécois identity and Québécois literature in the 1960s, La Corriveau was reborn as a Québécois symbol of nationalism and feminism that defied Québec's subordinate position within English Canada. In other words, the figure continued to function as a national allegory for Québec, but writers from the latter half of the twentieth century turned their attention more pointedly to nationalism's intersections with gender and feminism. Capturing Beaulieu's own nationalist sentiments, Ma Corriveau rejects Québec's self-perception as being colonized by English Canada. It presents not one, but two Corriveau figures, one serving as an allegory for a rural and retrograde Québec, and the other symbolizing a Québec that is nationally and sexually liberated. Whereas Beaulieu seeks to transvalue the woman-asnation trope (wherein La Corriveau represents both Québécois womanhood and nationhood) by embracing female sexuality, his use of women as objects representing 
national conquest, colonization, and nationalism undermines such efforts and consequently precipitates the collapse of his national dream. His contribution to the legend - the dual presentation of La Corriveau and the exploration of La Corriveau's potential with regard to feminist politics - is taken up seventeen years later by Hébert, whose play also tackles the discourses of nationalism and feminism. Approaching these discourses from a distinctly different angle, La cage shows how despite their opposing cultural, linguistic, and social positionings, Ludivine Corriveau and her symbolic twin Rosalinde Crebessa experience similar types of oppression by their husbands, who assume authoritative, patriarchal roles. No longer concerned with French-Canadian or English-Canadian solidarity, Ludivine defies patriarchy in her rallying of the community's rejections, creating a microcosmic version of Québécois society grounded in community-based affiliation rather than biologically based filiation. Hébert significantly revises previously malevolent versions of La Corriveau to present Ludivine as a nurturing mother figure who willingly co-operates with her peers to save Rosalinde and other marginalized individuals. This inclusive maternal Corriveau figure, however, is never fully taken up again in later iterations. Beaudin's Marie-Loup, for instance, promotes community-based affiliation through her identification with the Innu, but this is done paradoxically in ideological support of the biologically based filiation of the Québécois pure-laine society. Likewise, Chartrand's Marie-Josephte appears as a nurturing mother (at least in the first novel), but this portrayal only serves to legitimize Faustin's biological relations to pure-laine settlers.

A few years after Ludivine, La Corriveau is again reborn as an English-speaking Torontonian unaware of the Québécois people's linguistic and cultural struggles. The 
Ontarian author Glover employs the legend of La Corriveau to satirize English Canadians' myopia with regard to the Québécois. Through his short story “La Corriveau," he attempts to subvert the conventional symbolism attributed to the figureLa Corriveau as a French Canadian or Québécoise confronted by some sort of male, British authority figure — to disrupt heteronormative allegories of nationhood that characterize the relationship between Québec and English Canada. While portraying his unnamed protagonist's gender performance as swerving from cis-gendered femininity (a trait that defines the metaphor of Québec-as-wife as weak and subservient), however, Glover finds himself caught in a contradiction, for this also presents La Corriveau as a "masculinized" woman. Within the national allegory of English Canada that she embodies, Glover's La Corriveau continues to perpetuate the gender stereotypes inherent in the Québec-Canada relationship. She re-establishes English-Canadian dominance over Québec through the murder of Robert and employs a self-serving feminism. This seemingly subversive version of La Corriveau therefore unwittingly contradicts the liberationist project of the post-1960s Québécois iterations by reinforcing the QuébecCanada relations from which Beaulieu's and Hébert's figures try to break free.

Lessard's and Ménard's twenty-first-century works shift away from the entanglement of national allegory with gender and feminism, presenting La Corriveau as an emblem of more personal projects about family and faith. Lessard metaphorically gives birth to his ancestor in a work of life writing. Whether or not his claim of being a biological descendent of La Corriveau is true, An Object of Conviction is a fictional account of family history that takes as its project the reconciling of universal family values of self-sacrifice and love with the sinister story of La Corriveau. As I showed, 
however, this project remains entangled in the same national gender stereotypes that confound Glover's literary experiment. In presenting the narrative from the grandfather Joseph's perspective, Lessard, like Glover, inadvertently preserves the gender dynamics of male oppression over La Corriveau. Furthermore, although Joseph eventually comes to accept his daughter's questionable self-sacrifice as an act of love for her family and home, her actions concretize La Corriveau's association with the woman-as-nation trope in ways that echo Beaulieu's La Corriveau Noire and that anticipate the French Canadians' downfall as they, too, are codified as "feminine" and consequently, colonized.

In contrast to Glover's and Lessard's representation of English-French tensions in their respective works, Ménard's conte poétique titled Poupée de rouille centres instead on Marie-Josephte's romantic relationship with Dodier. In line with his own religious beliefs, Ménard resituates La Corriveau in a Roman Catholic context. His adaptation of the legend recuperates the figure in many ways. He subverts La Corriveau's portrayal as a malevolent witch or poisoner by imagining a benevolent, self-sacrificial, and loving wife, one who is much like Hébert's nurturing mother figure, Ludivine, but without the political backdrop of Québécois nationalism. Moreover, rather than be the exorcised, Marie-Josephte is the exorcist - the one who rids people of demons; accordingly, she recalls the purity that is ascribed to Beaudin's Marie-Loup, who absolves the French Canadians from their settler colonial condition, and ironically Chartrand's MarieJosephte, whose final death symbolically signifies the end of a pure (pure-laine), FrenchCanadian ancestral line. 
Whereas Lessard and Menard show how the consolidation of La Corriveau as a nationalist or feminist figure of the post-1960s period could be repurposed as the material for more intimate modes of reflection around family identity and spiritual belief outside of Québec, La Corriveau has also been resurrected in new, commodified material forms that continue to complicate her role as a mediator between Québec and Canada, as well as the world now. The legend's commodification and entrance into the global marketplace, I have argued, lead to a partial loss of La Corriveau's cultural, political, and historical background (as we already began to see with Glover, Lessard, and Ménard) and a concomitant return to old stereotypes in versions of the figure that target a larger audience. Canada Post's Haunted Canada stamp of La Corriveau recuperates gothic traits that initially characterized the figure, namely her association to witchcraft, and even her nationalist spirit. However, La Corriveau becomes on this stamp a domesticated image of French Canada as it is placed alongside, and given equal value to, various Canadian gothic legends. In this sense, the stamp brings Kirby's use of the figure one step further; rather than offering La Corriveau's death as a clear pathway for English-Canadian harmony (as Kirby had done), the stamp and its relation to the stamp series show how La Corriveau can be integrated into the English-Canadian metanarrative of nationhood. The return of La Corriveau's gibbet to Québec City, where it is displayed at the Musée de la civilisation, is an even more "overt" form of the legend's resurrection that brings with it the sinister revival of Québec as a gothic space of otherness. The museum emphasizes the sensational, gothic dimension of the gibbet to offer its tourists a self-exoticizing narrative. Emphasizing the notion of transgression, curators subtly (and most likely inadvertently) stage La Corriveau via her gibbet as a sort of victim that recalls the figure's earlier 
representation as a victim of British colonization in nineteenth-century texts, rather than its late-twentieth-century depiction as a rebellious nationalist in the theatrical productions. In contrast, Le Bilboquet uses neolocalism to market the beers " $\mathrm{La}$ Corriveau" and "La Corriveau Impériale." Its self-exoticization, performed through the exploitation of La Corriveau's gothic stereotypes, attracts Canadian and international consumers. At the same time, for locals, these beers can be seen as perpetuating La Corriveau's function as a Québécois nationalist symbol whose persistence in this instance derives from her successful commercialization. As these various material forms show, $\mathrm{La}$ Corriveau's relation to discourses of Québécois nationalism since the Quiet Revolution persists. Whether it be through the minimal retention of some "nationalistic" appearance as is the case with the stamp, or through its commercial success in self-exoticizing narratives such as the museum display of the gibbet and the marketing practices of local brewers, the figure's national meanings remain subject to savvy and subtle reimaginings.

La Corriveau's more recent rebirths mine yet another element of its nineteenthcentury presentation: the figure's initial gothic portrayal and identification with indigeneity. Whereas her first appearances coincided with a pivotal moment in the nation's reconfiguration at the hands of British invaders, her appearances in the twentyfirst century have been complicated by ongoing settler colonialism and Québec's struggles with settler colonial ambivalence in the face of the heightened visibility of Indigenous resurgence. Intended for international viewing, Beaudin's film NouvelleFrance instrumentalizes La Corriveau to promote Québec's settler colonial project. Marie-Loup's bonds of friendship with the Innu community set her up to be a protagonist with whom the audience can empathize, consequently facilitating the transformation of 
the unruly French soldiers of the Ancien Régime and the British invaders into scapegoats of the violent creation of the Canadian nation-state. Through her identification with the Innu, Marie-Loup “purifies” French Canadians (and contemporary Québécois viewers) of their colonial past, even as she appropriates the colonized position of Indigenous peoples, especially through the film's intertwining of her death with that of her adopted Innu daughter Acoona. Indeed, through La Corriveau's death, the film's attempts at ideological purification collapse insofar as La Corriveau ironically becomes legible as another scapegoat figure who accepts the punishment for colonial violence in the name of all French Canadians.

When La Corriveau is once again reborn into Chartrand's historical fantasy setting of the nineteenth century, the figure serves as the indigenizing tool for the Québécois protagonist Faustin. The figure's resurrections and extended genealogical line recall the ways in which de Gaspé uses La Corriveau's haunting presence as a means of substantiating the longevity of French Canadians' own presence on the land. While La Corriveau embodies a benevolent mother in the first installment of the trilogy, she ultimately becomes a grotesquely perverse, incestuous, and purely “evil” being that makes de Gaspé's witch seem harmless in comparison. As an aberration to the natural order, her rebirths cannot hold and her role as a symbolic placeholder for FrenchCanadian pure-laine identity gives way_or paves the way_to an even more problematic means of settler indigenization, evidenced in the revelation that Faustin's destiny is to protect all Indigenous populations as the white settler saviour. Unlike the highly politicized nationalism that typified the decades of the Quiet Revolution, these contemporary Québécois works show a new attachment to concealed settler nationalism; 
Québec becomes indistinct from any other nation that possesses a settler nationalist project as it seeks to project itself into the international arena. Thus, La Corriveau's most recent resurrections enable the figure to profit from its perceived identification with Indigenous peoples, who remain colonized and dispossessed on the home front.

La Corriveau's discursive history in Québec and English Canada reveals a figure that is at once highly charged and highly malleable. As a transgressive woman and murderess whose outsider status has been recuperated as a multivalent symbol of marginalization, La Corriveau has inspired cultural producers to portray her as identifying with and standing in for cultural outsiders such as Scots, Indigenous peoples, and Acadians. At the same time, the politically charged circumstances of MarieJosephte's trials link her to the history of Québec's conquest by English Canada, which sometimes binds her marginality to victimization; as a "victim" of unjust trials, she emblematizes Québec as a victim of the British Conquest. These types of identifications with cultural outsiders and victims are double-edged, for they predispose La Corriveau to come into conflict with other marginalized people such as racialized women and Indigenous peoples. Cultural producers have attempted to address these conflicts in two main ways, either by removing the figure's association with these identities or by attempting to work through these contradictions. As wider cultural attitudes about marginality and otherness have changed politically over the decades, so too have the pressures changed on the legend's embodiment of marginality. In rejecting, embracing, and transforming her marginality over the last two hundred and fifty-eight years, La Corriveau has mirrored an increasing awareness that Québec (and English Canada) is more diverse than its national metanarrative would suggest. As this national 
metanarrative continues to unravel, so will La Corriveau be reborn and give birth to new metaphors that try to make sense out of the Québécois nation and the complex knot of nations and identities to which the cultural history of La Corriveau has been attached. 


\section{Bibliography}

\section{Primary Sources}

Battle of the Brave. Directed by Jean Beaudin, performances by Noémin Godin-Vigneau, David La Haye, Irène Jacob, Jason Isaacs, Tim Roth, and Gérard Depardieu, Melenny Productions, 2004.

Beaulieu, Victor-Lévy. Ma Corriveau suivi de La sorcellerie en finale sexuée. VLB, 1976.

Chartrand, Sébastien. La voyante des Trois-Rivières. Alire, 2015.

---. L'ensorceleuse de Pointe-Lévy. Alire, 2013.

---. Le sorcier de l'île d'Orléans. Alire, 2016.

de Gaspé, Philippe Aubert (père). Les anciens Canadiens. Fides, 1961.

---. The Canadians of Old, translated by Charles G.D. Roberts, Appleton, 1890.

Glover, Douglas. 16 Categories of Desire. Goose Lane, 2000.

"Haunted Canada." Canada Post, 14 Jul. 2015, www.canadapost.ca/web/en/blogs/collecting/details.page?article=2015/09/14/haunte d_canada\&cattype $=$ collecting\&cat=stamps. Accessed 1 Nov. 2020.

"Haunted Canada Issued: June 13, 2014." Canada Post, 13 Jun. 2014, www.canadapost.ca/web/en/blogs/collecting/details.page?article=2014/06/13/haunte d_canada\&cattype $=$ collecting\&cat=stamps. Accessed 1 Nov. 2020.

“Haunted Canada Posted on Sept. 08, 2016.” Canada Post, 8 Sep. 2016, www.canadapost.ca/web/en/blogs/collecting/details.page?article=2016/09/08/haunte d_canada\&cattype $=$ collecting \&cat $=$ stamps. Accessed 23 May 2020.

Hébert, Anne. La cage suivi de L'île de la Demoiselle. Boréal, 1990. 
---. Two Plays: The Cage and L'Île de La Demoiselle, translated by Pamela Grant et al., Playwrights Canada P, 2010.

Kirby, William. Le Chien d'Or: The Golden Dog: A Legend of Quebec, edited by Mary Jane Edwards, McGill-Queen’s UP, 2012.

Le Bilboquet. "La Corriveau.” Saint-Hyacinthe, Québec.

Le Bilboquet. "La Corriveau Impériale.” Saint-Hyacinthe, Québec.

Lessard, Gene. An Object of Conviction: A Compelling Story of a Conquered People, Social Injustice and Family Tragedy. CreateSpace Independent Publishing Platform, 2016.

Ménard, David. Poupée de rouille. Interligne, 2018.

Nouvelle-France. Directed by Jean Beaudin, performances by Noémin Godin-Vigneau, David La Haye, Irène Jacob, Jason Isaacs, Tim Roth, and Gérard Depardieu, Melenny Productions, 2004.

“Sortir de sa réserve : 400 objets d'émotion.” Feb. 2018 - Sep. 2019, Musée de la Civilisation, Québec City, QC.

\section{$\underline{\text { Secondary Sources }}$}

“About PEM: Museum History.” Peabody Essex Museum, www.pem.org/aboutpem/museum-history. Accessed 11 May 2020.

Abu-Laban, Yasmeen, editor. Gendering the Nation-State Canadian and Comparative Perspectives. UBC P, 2008.

Ahuja, Kammy. "Kammy Ahuja Resume.” Behance, www.behance.net/Kammy_Singh/resume. Accessed 13 Aug. 2020. 
"Alexander Brott." Orchestre symphonique de Montréal, www.osm.ca/en/alexanderbrott. Accessed 16 Jun. 2019.

Alioff, Maurie. “Nouvelle-France.” Take 1, vol. 13, no. 49, 2005, p. 34.

Angers, F. Réal. Les révélations du crime : ou, Cambray et ses complices. RééditionQuébec, 1969.

“À propos du Carnaval.” Carnaval de Québec, carnaval.qc.ca/fr/le-carnaval/a-proposcarnaval. Accessed 16 Apr. 2020.

Aquin, Hubert. Blocs erratiques. Typo, 1998.

---. Trou de mémoire. Cercle du livre de France, 1968.

Armstrong, Lise, and Diane Miljours. "Décoller du réalisme : entrevue avec Lorraine Pintal." Jeu, vol. 25, no. 4, 1982, pp. 173-85.

Ashcroft, Bill, et al. "Othering." Post-Colonial Studies: The Key Concepts, 3rd ed., Routledge, 2013, pp. 188-90.

"Ask the Author: Gene Lessard." Goodreads, www.goodreads.com/author/6611663.Gene_Lessard/questions?fbclid=IwAR07OD YJaWqyLN4a4LGIS9mB6VaM51w_tcwLjuSsKNmfAfVyW26o533yrHI. Accessed 16 Apr. 2020.

Audet, Pierre-E. Les officiers de justice : des origines de la colonie jusqu'à nos jours. Wilson \& Lafleur, 1986.

Aykroyd, Peter H. The Anniversary Compulsion: Canada's Centennial Celebration, A Model Mega-Anniversary. Dundurn P, 1992.

Bannerji, Himani. "On the Dark Side of the Nation." The Dark Side of the Nation: Essays on Multiculturalism, Nationalism and Gender, Canadian Scholars' P, 2000, pp. 87- 
124.

Beaton, Meaghan Elizabeth. The Centennial Cure: Commemoration, Identity, and Cultural Capital in Nova Scotia during Canada's 1967 Centennial Celebrations. Toronto UP, 2017.

Beaulieu, Victor-Lévy. Jos Connaissant, VLB, 1978.

---, creator. L'héritage. Radio-Canada, 1987.

---, creator. Montréal P.Q., Radio-Canada, 1992.

---, creator. Race du monde. Radio-Canada, 1978.

---. Un rêve québécois, Éditions du Jour, 1972.

Beaulieu, Victor-Lévy, and Margaret Atwood. Deux sollicitudes. Éditions Trois-Pistoles, 1996.

Bedrossian, Rebecca. "Sam Weber." Communication Arts, www.commarts.com/features/sam-weber. Accessed 13 Aug. 2020.

Behiels, Michael D. "Francophone-Anglophone Relations." The Canadian Encyclopedia, Historica Canada, 2019.

Bélair, Michel. Le nouveau théâtre québécois. Leméac, 1973.

Belshaw, John Douglas. Canadian History: Post-Confederation. BCcampus, 2016.

---. Canadian History: Pre-Confederation. BCcampus, 2015.

Bendix, Regina. "Fakelore.” Folklore: An Encyclopedia of Beliefs, Customs, Tales, Music, and Art, Volume 1, edited by Thomas A. Green, ABC-CLIO, 1997, pp. 27577.

Bentley, D. M. R. The Confederation Group of Canadian Poets, 1880-1897. Toronto UP, 2004. 
Berger, Carl. The Sense of Power: Studies in the Ideas of Canadian Imperialism, 18671914. 2nd ed., Toronto UP, 2013.

Bergeras, Yves. “Les ailes de la Corriveau.” Le Droit, 5 Oct. 2018.

Bergeron, Bertrand, and Jean-Pierre Pichette. “Annexe I - Biographie de Marie-Josephte Corriveau." La Corriveau : la formation d'une légende, edited by Bertrand Bergeron and Jean-Pierre Pichette, Laval UP, 2017, pp. 137-40.

Bhabha, Homi K. The Location of Culture. Routledge, 1994.

Billig, Michael. Banal Nationalism, SAGE, 1995.

Biron, Michel, et al. Histoire de la littérature québécoise. Boréal, 2007.

Blodgett, E.D. “Canadian Literature Is Comparative Literature.” College English, vol. 50, no. 8,1988, pp. $904-11$.

---. Configuration: Essays in the Canadian Literatures. ECW P, 1982.

---. "Is a History of the Literatures of Canada Possible?" Essays on Canadian Writing, no. 50, 1993, pp. 1-11.

Bode, Carl. "The Buxom Biographies.” College English, vol. 16, no. 5, 1955, pp. 265-69. Boivin, Aurélien. “Jos Violon, un vrai conteur populaire au XIX ${ }^{\mathrm{e}}$ siècle.” Francophonies d'Amérique, vol. 5, 1995, pp. 189-207.

Boltanski, Luc. Distant Suffering Morality, Media, and Politics, translated by Graham Burchell. Cambridge UP, 1999.

---. La souffrance à distance : morale humanitaire, médias et politique. Éditions Métailié, 1993.

Boswell, Hazel. French Canada: Pictures and Stories. Viking, 1938.

Boudreau, Diane. Histoire de la littérature amérindienne au Québec : oralité et écriture. 
L'Hexagone, 1993.

Boyle, Karen. Media and Violence: Gendering the Debates. SAGE, 2005.

Bracken, Laura. “International Sales Could Save Nouvelle France.” Playback: Canada's Broadcast and Production Journal, 2005, p. 2.

Brady, Elizabeth. “A Bibliographical Essay on William Kirby’s The Golden Dog, 18771977." Papers of the Bibliographical Society of Canada, vol. 15, no. 1, 1976, pp. 24-48.

Brantlinger, Patrick. Rule of Darkness: British Literature and Imperialism, 1830-1914. Cornell UP, 1988.

Brennan, Sheila. Stamping American Memory: Collectors, Citizens, and the Post. Michigan UP, 2018.

Broadhead, Alex. The Language of Robert Burns: Style, Ideology, and Identity. Bucknell UP, 2014.

Brousseau, Jean-Paul. “Ma Corriveau, folie et sorcellerie.” La Presse, 18 Jan. 1979, p. 13.

Brown, George W. "Canadian Nationalism: An Historical Approach.” International Affairs (Royal Institute of International Affairs 1944-), vol. 30, no. 2, 1954, pp. 16674.

Brown, Ron. Rails Over the Mountains: Exploring the Railway Heritage of Canada's Western Mountains. Dundurn P, 2016.

Brun, Josette. Vie et mort du couple en Nouvelle-France: Québec et Louisbourg au XVIII siècle. McGill-Queen's UP, 2006.

Brunet, Michel. "Les Canadiens après la conquête : les débuts de la résistance passive." 
Revue d'histoire de l'Amérique française, vol. 12, no. 2, 1958, pp. 170-207.

Bunten, Alexis Celeste. "Sharing Culture or Selling Out? Developing the Commodified Persona in the Heritage Industry." American Ethnologist, vol. 35, no. 3, 2008, pp. $380-95$.

Burelle, Julie. Encounters on Contested Lands: Indigenous Performances of Sovereignty and Nationhood in Québec. Northwestern UP, 2018.

Burns, Robert. “Tam O’Shanter.” Tam O'Shanter, Project Gutenberg.

Cabajsky, Andrea. "Eighteenth- \& Nineteenth-Century French-Canadian Literature.” The Oxford Handbook of Canadian Literature, edited by Cynthia Sugars, 2016, pp. 24259.

---. "Introduction." The Manor House de De Villerai: A Tale of Canada under the French Dominion by Roseanna Mullins Leprohon, edited by Andrea Cabajsky, Broadview P, 2014, pp. 9-32.

Cadieux, Alexandre. "Le conte québécois : quelques voyagements." Jeu, vol. 131, no. 2, 2009, pp. 113-21.

"Cage of la Corriveau on display in Lévis." CBC News, 5 Oct. 2013, www.cbc.ca/news/canada/montreal/cage-of-la-corriveau-on-display-in1\%C3\%A9vis-1.1913940. Accessed 30 Nov. 2020.

Caldwell, Gary. Les études éthniques au Québec : bilan et perspectives. Institut québécois de recherche sur la culture, 1983.

Cardinal, Jacques. La paix des braves : une lecture politique des anciens Canadiens de Philippe Aubert de Gaspé. XYZ éditeur, 2005.

Carter, Adam. "National Literature, Canadian Criticism, and National Character." The 
Oxford Handbook of Canadian Literature, edited by Cynthia Sugars, Oxford UP, 2016, pp. 41-63.

Castonguay, Jacques. “Aubert de Gaspé, Pierre-Ignace.” Dictionnaire biographique du Canada, Laval UP/Toronto UP, www.biographi.ca/fr/bio/aubert_de_gaspe_pierre_ignace_6F.html. Accessed 5 Sep. 2019

---. Philippe Aubert de Gaspé : seigneur et homme de lettres. Septentrion, 1991.

Céline Dion. "Ma Nouvelle-France." On ne change pas, Columbia Records, 2005.

Chapman, Nathaniel G., et al. "Bottling Gender: Accomplishing Gender Through Craft Beer Consumption." Food, Culture \& Society, vol. 21, no. 3, 2018, pp. 296-313.

Chapman, Rosemary. What Is Québécois Literature?: Reflections on the Literary History of Francophone Writing in Canada. Liverpool UP, 2013.

Choi, Chungmoo. "Nationalism and Construction of Gender in Korea." Dangerous Women: Gender and Korean Nationalism, edited by Elaine H. Kim and Chungmoo Choi, Routledge, 1998, pp. 9-32.

Claramonte, Carmen África Vidal. "Power." The Routledge Handbook of Translation and Culture, edited by Sue-Ann Harding and Ovidi Carbonell Cortés, Routledge, 2018, pp. 79-98.

Coates, Colin MacMillan, and Cecilia Louise Morgan. Heroines and History: Representations of Madeleine de Verchères and Laura Secord. Toronto UP, 2002.

Cohen, Erik. "Authenticity and Commoditization in Tourism." Annals of Tourism Research, vol. 15, no. 3, 1988, pp. 371-86.

Coleman, Daniel. White Civility: The Literary Project of English Canada. Toronto UP, 
2006.

“Collectible Stamps and Coins." Canada Post, www.canadapost.ca/cpc/en/personal/stamps-collectibles.page. Accessed 14 Oct. 2020.

“Communiqué de presse : sortir de sa réserve: 400 objets d'émotion.” Musée de la civilisation, www.mcq.org/en/communiquepresse?id=712722\#: :text=Premi\%C3\%A8re\%20manifestation $\% 20 \mathrm{c} \% \mathrm{C} 3 \% \mathrm{~A} 91 \% \mathrm{C}$ 3\%A9brant $\% 20$ son $\% 2030$, les $\% 20$ objets $\% 20 \mathrm{de} \% 20$ ses $\% 20$ collections!. Accessed 28 Apr. 2019.

Conan, Laure. Angéline de Montbrun. Boréal, 2012.

Conway, John Frederick. Debts to Pay: English Canada and Quebec from the Conquest to the Referendum. J. Lorimer, 1992.

Cornellier, Bruno. La “chose indienne” : cinéma et politiques de la représentation autochtone dans la colonie de peuplement libérale. Concordia U, 2011, spectrum.library.concordia.ca/36031/1/Cornellier_PhD_S2012-2.pdf.

Corriveau, Hugues, et al. Meurtres à Québec. L’instant même, 1993.

Cortés, Ovidi Carbonell, and Sue-Ann Harding. “Introduction: Translation and Culture.” The Routledge Handbook of Translation and Culture, edited by Sue-Ann Harding and Ovidi Carbonell Cortés, Routledge, 2018, pp. 1-14.

Côté, Michel. "Les musées de société : le point de bascule." Hermès, vol. 61, no. 3, 2011, pp. 113-18. 
Côté Dupuis, Alice. “'Poupée de rouille' de David Ménard : imaginer la vérité.” Regroupement des éditeurs franco-canadiens, 10 Oct. 2018, refc.ca/73-poupeede-rouille-de-david-menard. Accessed 1 Oct. 2020.

Couture-Grondin, Élise. “Analyse antiraciste du rapport au territoire, à l'autre et à l'écriture dans Aimititau! Parlons-Nous!" Voix plurielles, vol. 13, no. 2, 2016, pp. $127-49$.

Crawford, Isabella Valancy. Winona; or, The Foster-Sisters, edited by Leonard Roy Early and Michael A. Peterman. Broadview P, 2007.

Crawford, Thomas. Burns: A Study of Poems and Songs. Canongate Academic, 1994.

Creative Bloq Staff. "Sam Weber." Creative Bloq: Art and Design Inspiration, 8 Sep. 2008, www.creativebloq.com/computer-arts/sam-weber-9089253. Accessed 24 Jul. 2020.

Cultural Mission: Musées de la civilisation. Ministère de la Culture et des Communications, 2013.

Dagenais, Maxime. “'La mort du conseil spécial est la meilleure action que ce corps ait faite durant sa vie $[\ldots]$ ': The French-Canadian Press and the Special Council of Lower Canada, 1838-1841.” Quebec Studies, vol. 62, Dec. 2016, pp. 25-46.

Daoust, Jean-Paul. “Ma Corriveau.” Jeu, vol. 4, 1977, pp. 81-82.

Darwin, Helana. "You Are What You Drink: Gender Stereotypes and Craft Beer Preferences within the Craft Beer Scene of New York City." Untapped, edited by Nathaniel G. Chapman et al., West Virginia UP, 2017, pp. 222-35.

de Gaspé, Philippe Aubert (fils). Le chercheur de trésors : ou, L'influence d'un livre. Réédition-Québec, 1968. 
de la Concha, Ángeles. "Erasing Female Victimhood: The Debate over Trauma and Truth." Victimhood and Vulnerability in 21st Century Fiction, edited by Jean-Michel Ganteau and Susana Onega, Taylor \& Francis, 2017, pp. 71-89.

Demers, Jeanne, and Lise Gauvin. “Autour de la notion de conte écrit.” Études françaises, vol. 12, no. 1-2, 1976, pp. 157-77.

Denby, Priscilla. "Folklore in The Mass Media." Folklore Forum, vol. 4, 1971, pp. 11325.

Deschamps, Nicole. “Les 'anciens Canadiens' de 1860.” Études françaises, vol. 1, no. 3, 1965, p. 3.

Desroches, Nadine. "Le théâtre des femmes." Le théâtre québécois, 1975-1995, edited by Dominique Lafon, Fides, 2001, pp. 111-32.

Dickinson, John Alexander, and Brian J. Young. A Short History of Quebec. 4th ed., McGill-Queen's UP, 2008.

Dickinson, Peter. Here Is Queer: Nationalism, Sexualities, and the Literatures of Canada. Toronto UP, 1999.

Dickson, Robert. "La 'révolution culturelle' en Nouvel-Ontario et le Québec.” Produire la culture, produire l'identité?, edited by Andrée Fortin, Laval UP, 2000, pp. 183202.

"Document Called Copy of the Proceedings of a General Court Martial Held at Quebec the 15th Day of April 1763, By Virtue of a Warrant from His Excellency Governor Murray, Dated the 14th Day of the Same Month." War Office Judge Advocate General Dept. Courts Martial Proceedings (W.O. 71), vol. 49, pp. 213-14.

Doern, G. Bruce, et al. Canadian Multimodal Transport Policy and Governance. McGill- 
Queen's UP, 2019.

Dorion, Gilles. "Victor-Lévy Beaulieu : le pouvoir des mots." Québec français, no. 45, 1982, pp. 47-49.

Dorson, Richard M. “Fakelore.” Zeitschrift Für Volkskunde, vol. 65, 1969, pp. 56-64.

Downie, Mary A. The Witch of the North: Folk Tales of French Canada. Oberon P, 1975.

Ducharme, Nathalie. Le roman d'aventures au Québec (1837-1900). Laval UP, 2019.

Dumais, Éric. “'L'entrevue éclair avec...' David Ménard, poète au regard pénétrant.” Bible urbaine, 2019, www.labibleurbaine.com/litterature/lentrevue-eclair-avecdavid-menard-poete-au-regard-penetrant. Accessed 24 Nov. 2020.

Dumais, Manon. "Noémie Godin-Vigneau : le lys brisé." Voir, Nov. 2004, voir.ca/cinema/2004/11/18/noemie-godin-vigneau-le-lys-brise. Accessed 25 Nov. 2020.

Dupré, Louise. "L’héritage littéraire au Québec." Le centenaire d'Anne Hébert : approches critiques, edited by Nathalie Watteyne, Montréal UP, 2018, pp. 155-66.

Dyer, Klay. “Kirby, William.” Encyclopedia of Literature in Canada, edited by W.H. New, Toronto UP, 2002, p. 581.

Eakin, Paul John. Writing Life Writing: Narrative, History, Autobiography. Routledge, 2020.

Early, Leonard Roy, and Michael A. Peterman. "Introduction." Winona; or, The FosterSisters by Isabella Valancy Crawford, edited by Len Early and Michael A. Peterman, Broadview P, 2007, pp. 9-61.

Edwards, Justin D. Gothic Canada: Reading the Spectre of a National Literature. Alberta UP, 2005. 
Edwards, Mary Jane. "Editor's Introduction: The Anatomy of a Novel.” The Golden Dog, edited by Mary Jane Edwards, McGill-Queen's UP, 2012, pp. xix-clxxii.

---. "Kirby, William." Dictionary of Canadian Biography, Laval UP/Toronto UP, www.biographi.ca/en/bio/kirby_william_13E.html. Accessed 13 Oct. 2019.

Edwardson, Ryan. "The Many Lives of Captain Canuck: Nationalism, Culture, and the Creation of Canadian Comic Book Superhero." Journal of Popular Culture, vol. 37, no. 2, 2003, pp. 184-201.

Falk, John H., et al. "Living in a Learning Society: Museums and Free-Choice Learning." A Companion to Museum Studies, edited by Sharon Macdonald, Blackwell Publishing, 2006, pp. 323-39.

Ferland, Catherine, and Dave Corriveau. La Corriveau : de l'histoire à la légende. 1st ed., Septentrion, 2013.

---. La Corriveau : de l'histoire à la légende. 2nd ed., Septentrion, 2014.

Fischer, Gerhard, and Bernhard Greiner. "The Play within the Play: Scholarly Perspectives." The Play Within the Play: The Performance of Meta-Theatre and Self-Reflection, Rodopi, 2007, pp. xii-xvi.

Forsyth, Louise. "Introduction.” Two Plays: The Cage and L'Île de La Demoiselle, translated by Pamela Grant et al., Playwrights Canada P, 2010, pp. ix-xviii.

Francis, Daniel. National Dreams: Myth, Memory, and Canadian History. Arsenal Pulp P, 1997.

Frank, David. "The Labour Stamp: The Image of the Worker on Canadian Postage Stamps." Labour/Le Travail, vol. 39, 1997, pp. 179-94.

Fréchette, Louis. "La cage de la Corriveau." La Patrie, 24 Jan. 1885, p. 10-20. 
---. La legende d'un peuple. Editions Beauchemin, 1941.

---. Originaux et détraqués. Patenaude, 1892.

---. "Une relique-La Corriveau." Almanach du people Beauchemin, Librairie Beauchemin, 1913, pp. 302-307.

---. “Une touffe de cheveux blancs." L'Opinion publique, 25 Apr. 1872, p. 202.

Frégault, Guy. Canadian Society in the French Regime. Canadian Historical Association, 1954.

Fulford, Robert. “Canadian Gothic Explores Our Writers' Spooky Ways.” National Post, 19 Mar. 2014.

Fyson, Donald. "Judicial Auxiliaries Across Legal Regimes: From New France to Lower Canada." Entre justice et justiciables : les auxiliaires de la justice du Moyen Âge au XXe siècle, edited by Claire Dolan, Laval UP, 2005, pp. 383-403.

Gadoury, Lionel. "Lionel Gadoury RGD.” ExpertFile, expertfile.com/experts/lionel.gadouryrgd\#biography. Accessed 13 Aug. 2020.

Gagnon, Alex. La communauté du dehors : imaginaire social et crimes célèbres au Québec (XIX $-X X^{e}$ siècle). Montréal UP, 2016.

Garneau, François-Xavier. Histoire du Canada depuis sa découverte jusqu'à nos jours. Imprimerie de N. Aubin, 1845-1852.

Gauthier, Serge. Charlevoix ou la création d'une région folklorique : étude du discours de folkloristes québécois (1916-1980). Laval UP, 2006.

Gauvin, Lise. "Du tourment de langage à l'imaginaire des languages : 'langagement des écrivains québécois." L'écrivain et sa langue : romans d'amour de Marcel Proust à Richard Millet, edited by Sylviane Coyault, Blaise-Pascal UP, 2005, pp. 317-24. 
Gebara, Ivone. Le mal au féminin : réflexions théologiques à partir du féminism. L’Harmattan, 1999.

---. Out of the Depths: Women's Experience of Evil and Salvation, translated by Ann Patrick Ware, Augsburg Fortress Publishers, 2002.

"Gene Lessard.” Amazon Author Pages, www.amazon.com/GeneLessard/e/B00HX25IDM\%3Fref=dbs_a_mng_rwt_scns_share. Accessed 15 Apr. 2020.

Gerson, Carole. A Purer Taste: The Writing and Reading of Fiction in English in Nineteenth-Century Canada. Toronto UP, 1989.

---. "Terrien Romance, Terroir, and Roman de La Terre." Encyclopedia of Literature in Canada, edited by W.H. New, Toronto UP, 2002, p. 1096.

Glover, Douglas. Bad News of the Heart. Dalkey Archive P, 2003.

---. Notes Home from a Prodigal Son. Oberon P, 1999.

---. Seize sortes de désir, translated by Micheline Lanctôt. Boréal, 2004.

Goldie, Terry. In a Queer Country: Gay and Lesbian Studies in the Canadian Context. Arsenal Pulp P, 2001.

Goldman, Marlene. DisPossession: Haunting in Canadian Fiction. McGill-Queen's UP, 2012.

---. Rewriting Apocalypse in Canadian Fiction. McGill-Queen's UP, 2005.

Goor, Dan, and Michael Schur, creators. Brooklyn Nine-Nine. NBCUniversal Television Distribution, 2013.

Greene, Michael. "Gothic and Grotesque." Encyclopedia of Literature in Canada, edited by W.H. New, Toronto UP, 2002, pp. 443-444. 
Greenwood, F. Murray, and Beverly Boissery. Uncertain Justice: Canadian Women and Capital Punishment, 1754-1953. Dundurn P, 2000.

Greer, Allan. Peasant, Lord, and Merchant: Rural Society in Three Quebec Parishes, 1740-1840. Toronto UP, 1985.

Griffiths, Naomi. From Migrant to Acadian: A North American Border People. McGillQueen's UP, 2005.

---. "The Golden Age: Acadian Life, 1713-1748." Histoire sociale/Social History, vol. 17 , no. 33,1984 , pp. 21-34.

Gringhuis, Dirk. Were-Wolves and Will-o-the-Wisps: French Tales of Mackinac Retold. Mackinac Island State Park Commission, 1974.

Gross, Louis S. Redefining the American Gothic: From Wieland to Day of the Dead. UMI Research, 1989.

Guay, Jean-Herman. "Sovereignty at an Impasse: The Highs and Lows of Quebec Nationalism." IRPP Insight, no. 18, Oct. 2017, pp. 1-30.

Guiley, Rosemary. "Red." The Encyclopedia of Witches, Witchcraft and Wicca, Infobase Publishing, 2008, p. 286.

Haase, Donald. "Nationalism." The Greenwood Encyclopedia of Foktales and Fairy Tales, Volume 1: A-F, edited by Donald Haase, Greenwood P, 2008, pp. 662-63.

Hagen, Rune Blix. "Witchcraft Criminality and Witchcraft Research in the Nordic Countries." The Oxford Handbook of Witchcraft in Early Modern Europe and Colonial America, edited by Brian P. Levack, Oxford UP, 2013, pp. 375-92.

Hale, Katherine. Legends of the St. Lawrence. Canadian Pacific Railway, 1926. Hale, Terry. "Frénétique School." The Handbook to Gothic Literature, edited by Marie 
Mulvey-Roberts, MacMillan P, 1998, pp. 58-63.

Handler, Richard. Nationalism and the Politics of Culture in Quebec. Wisconsin UP, 1988.

Harris, Jason Marc. Folklore and the Fantastic in Nineteenth-Century British Fiction. Routledge, 2016.

Harvilahti, Lauri. "Romantic Nationalism.” Folklore: An Encyclopedia of Beliefs, Customs, Tales, Music, and Art, Volume 1, edited by Charlie T. McCormick and Kim Kennedy White, 2nd ed., ABC-CLIO, 2010, pp. 737-41.

Hastings, Paula. “'Our Glorious Anglo-Saxon Race Shall Ever Fill Earth's Highest Place': The Anglo-Saxon and the Construction of Identity in Late-NineteenthCentury Canada." Canada and British World: Culture, Migration, and Identity, edited by Phillip Buckner and R. Douglas Francis, UBC P, 2006, pp. 92-110. Hayne, David. “The Golden Dog and Le Chien d'or: Le May's French Translation of Kirby's Novel." Papers of the Bibliographical Society of Canada, vol. 20, p. 50-62.

Hébert, Anne. A gaiola de ferro, translated by Nubia Hanciau. Editora da FURG, 2003.

---. Kamouraska. Editions du Seuil, 1970.

---. Les fous de Bassan. Editions du Seuil, 1982.

---. Le torrent. Editions Beauchemin, 1950.

Helfield, Gillian. 'I' y ava’t un' fois (Once Upon a Time): Films as Folktales in Québécois Cinéma Direct." Folklore/Cinema: Popular Film as Vernacular Culture, edited by Sharon R. Sherman and Mikel J. Koven, Utah State UP, 2007, pp. 10-30. "Historical Note." Ministère de la Justice de Québec, Gouvernement du Québec, www.justice.gouv.qc.ca/en/department/historical-note. Accessed 21 Jul. 2018. 
Horkheimer, Max, and Theodor W. Adorno. "The Culture Industry: Enlightenment as Mass Deception.” Dialectic of Enlightenment, edited by Gunzelin Schmid Noerr and translated by Edmund Jephcott, Stanford UP, 2020, pp. 94-136.

Hotte, Lucie, and Johanne Melançon, editors. Introduction à la littérature francoontarienne. Prise de parole, 2010.

Huard, Patrick, creator. Escouade 99. Club Illico, 2020.

Huddart, David. Homi K. Bhabha. Routledge, 2006.

Hughes, William. “Imperial Gothic.” Historical Dictionary of Gothic Literature, Scarecrow P, 2013, pp. 141-42.

Huot, Édouard. “Causerie.” L'Opinion publique, 21 Mar. 1872, p. 135.

Hurley, Erin. National Performance: Representing Quebec from Expo 67 to Celine Dion. Toronto UP, 2011.

Hussein, Abdirahman A. Edward Said: Criticism and Society. Verso, 2002.

Hutcheon, Linda. A Poetics of Postmodernism: History, Theory Fiction. Taylor and Francis, 2003.

---. Narcissistic Narrative: The Metafictional Paradox. Wilfrid Laurier UP, 2013.

---. The Canadian Postmodern: A Study of Contemporary English-Canadian Fiction. Oxford UP, 1988.

Ivanovic, Milena. Cultural Tourism. Juta and Company, 2008.

J.A. Martin, photographe. Directed by Jean Beaudin, performances by Marcel Sabourin and Monique Mercure, National Film Board of Canada, 1977.

Johnson, E. Pauline. "A Strong Race Opinion: On the Indian Girl in Modern Fiction.” Introduction to Indigenous Literary Criticism in Canada, edited by Heather 
Macfarlane and Armand Garnet Ruffo, Broadview P, 2016, pp. 1-6.

Jones, Patricia. "Mad Colonial Narrators in Anglo-Irish Literature: Lemuel Gulliver and Freddie Montgomery.” International Journal of Applied Linguistics \& English Literature, vol. 7, no. 2, 2018, pp. 33-41.

Kadar, Marlene, editor. Essays on Life Writing: From Genre to Critical Practice. Toronto UP, 1992.

Kamboureli, Smaro. Scandalous Bodies: Diasporic Literature in English Canada. Oxford UP, 2000.

---. "The Diaspora Writes Back: Cultural Memory and Michael Ondaatje's Anil's Ghost." Diasporic Subjectivity and Cultural Brokering in Contemporary Post-Colonial Literatures, edited by Igor Maver, Lexington Books, 2009, pp. 27-38.

Kaplan, Caren, et al., editors. Between Woman and Nation: Nationalisms, Transnational Feminisms, and the State. Duke UP, 1999.

Kelly, Brendan. "Love in a Time of Big Budgets: Epic Romance Nouvelle-France is Quebec's Answer to Titanic: Toronto Edition.” National Post, 15 Nov. 2004, p. AL3.

Kendall, Paul Murray. The Art of Biography. Norton, 1967.

Kertzer, Jonathan. Worrying the Nation: Imagining a National Literature in English Canada. Toronto UP, 1998.

Khair, Tabish. The Gothic, Postcolonialism and Otherness: Ghosts from Elsewhere. Palgrave Macmillan, 2009.

Killeen, Jarlath. The Emergence of Irish Gothic Fiction: History, Origins, Theories. Edinburgh UP, 2013. 
King, Betty Nygaard, and Gilles Potvin. "Alexander Brott." The Canadian Encyclopedia, Historica Canada, 2015.

Kirby, William. The Golden Dog (Le Chien D'or): A Romance of the Days of Louis Quinze in Quebec. Lovell, Coryell, 1877.

Koenig Kellas, Jody. "Family Ties: Communicating Identity Through Jointly Told Family Stories.” Communication Monographs, vol. 72, no. 4, 2005, pp. 365-89.

---. "Framing Family: An Introduction.” Family Storytelling: Negotiating Identity, Teaching Lessons, and Making Meaning, edited by Jody Koenig Kellas, Routledge, 2013, pp. 1-13.

Kroetsch, Robert. "Disunity as Unity: A Canadian Strategy." Unhomely States:

Theorizing English-Canadian Postcolonialism, edited by Cynthia Sugars, Broadview P, 2004, pp. 61-70.

Lackey, Michael. "Locating and Defining the Bio in Biofiction." A/b: Auto/Biography Studies, vol. 31, no. 1, 2016, pp. 3-10.

La Corrivaux. Directed by Jean Salvy, performances by Anne Dorval, Charles Boisseau, and Raymond Bouard, Radio-Canada, 1995.

“La Corriveau.” Pinterest, www.pinterest.ca/pin/336855247104985510. Accessed 18 Jul. 2020.

“La Corriveau Impériale” Pinterest, www.pinterest.ca/pin/336855247104838072. Accessed 18 Jul. 2020.

Lacourcière, Luc. “Corriveau, Marie-Josephte.” Dictionary of Canadian Biography, Laval UP/Toronto UP, www.biographi.ca/fr/bio/corriveau_marie_josephte_3F.html. Accessed 1 Apr. 2019. 
---. La Corriveau : la formation d'une légende, edited by Bertrand Bergeron and JeanPierre Pichette, Laval UP, 2017.

---. "Le destin posthume de la Corriveau." La Corriveau : la formation d'une légende, edited by Bertrand Bergeron and Jean-Pierre Pichette, Laval UP, 2017, pp. 69-100.

---. "Le triple destin de Marie-Josephte Corriveau (1733-1763)." La Corriveau : la formation d'une légende, edited by Bertrand Bergeron and Jean-Pierre Pichette, Laval UP, 2017, pp. 39-68.

---. "Présence de la Corriveau." La Corriveau : la formation d'une légende, edited by Bertrand Bergeron and Jean-Pierre Pichette, Laval UP, 2017, pp. 101-135.

Ladouceur, Louise. Making the scene : la traduction du théâtre d'une langue officielle à l'autre au Canada. Nota Bene, 2006.

"L'affaire Delorme.” Histoire du Québec, histoire-du-quebec.ca/affaire-delorme. Accessed 16 Jun. 2020.

Lahaie, Christiane. Anne Hébert et la critique. Fides, 2003.

Lake, Medicine Grizzlybear. Native Healer: Initiation into an Ancient Art. Quest Books, 2006.

Lamonde, Yvan. Histoire sociale des idées au Québec. Fides, 2000.

---. The Social History of Ideas in Quebec, 1760-1896, translated by Phyllis Aronoff and Howard Scott. McGill-Queen's UP, 2013.

Lamoureux, Diane. "Feminism and Nationalism in Québec." Gendering Nationalism: Intersections of Nation, Gender and Sexuality, edited by Jon Mulholland et al., Palgrave Macmillan, 2018, pp. 187-202.

Landry, Pierre-Luc, and Zishad Lak. "Le colonialisme de peuplement et la critique 
québécoise et franco-canadienne.” $A L C Q-A C Q L, 2019$, alcq-acql.ca/fr/acqlsconferences/2019-vancouver/settler-colonialism. Accessed 1 Oct. 2020.

Langbein, John H. The Origins of Adversary Criminal Trial. Oxford UP, 2003.

Langellier, Kristin M., and Eric E. Peterson. "Family Storytelling as a Strategy of Social Control." Narrative and Social Control: Critical Perspectives, edited by Dennis K. Mumby, SAGE, 1993, pp. 49-76.

Langlois, Roméo. “Une Barbe-Bleue canadienne : la Corriveau.” Le Magazine de Québec, 7 Jan. 1939, p. 3.

Lanthier, Stéphanie. L'impossible réciprocité des rapports politiques et idéologiques entre le nationalisme radical et le féminisme radical au Québec, 1961-1972. Sherbrooke U, 1998.

"La saison des grands ballets canadiens : 4 ballets dont 'Giselle' et deux créations modernes marquent une étape pour la compagnie montréalaise." Le Devoir, 24 Nov. 1966, pp. 1-16.

Lasnier, Louis. Les noces chymiques de Philippe Aubert de Gaspé dans L'influence d'un livre. Laval UP, 2002.

Laurendeau, Pierre. Victor-Lévy Beaulieu en six temps : l'espace d'un œuvre : de la ténèbre à la lumière. Laval UP, 2012.

Leader, Zachary. On Life-Writing. Oxford UP, 2015.

Lebel, Andrée. La Corriveau. Éditions Libre Expression, 1981.

"Le Bilboquet La Corriveau." ratebeer.com, www.ratebeer.com/beer/le-bilboquet-lacorriveau/18018. Accessed 1 Nov. 2020.

"Le Bilboquet La Corriveau Impériale (Bourbon).” ratebeer.com, 
www.ratebeer.com/beer/le-bilboquet-la-corriveau-imperiale-bourbon/210923. Accessed 1 Nov. 2020.

LeBlanc, Julie M-A. "Branding Unibroue: Selling Québécois Folklore through Beer." The Folklorist in the Marketplace: Conversations at the Crossroads of Vernacular Culture and Economics, edited by Willow G. Mullins and Puja Batra-Wells, Utah State UP, 2019, pp. 47-71.

Lecker, Robert. Keepers of the Code: English-Canadian Literary Anthologies and the Representation of the Nation. Toronto UP, 2017.

Leclaire, Armand. "Les sorciers de l'Île d'Orléans ou La Corriveau." Le Passe-temps, vol. 23 , no. 572, 1917 , pp. 63-64.

Legaré, Francine. Samuel de Champlain: Father of New France. XYZ Pub, 2004.

Légis Québec: M-44 National Museum Acts, Section 24.1. legisquebec.gouv.qc.ca/en/showversion/cs/M44? code $=$ se:24_1\&pointInTime=20161029. Accessed 16 Jun. 2020.

Lemire, Maurice. "La trahison de Bigot dans le roman historique canadien." Revue d'histoire de l'Amérique française, vol. 22, no. 1, 1968, pp. 65-88.

---, editor. La vie littéraire au Québec, volume 3. Laval UP, 1996.

Le Moine, J. M. Maple Leaves: A Budget of Legendary, Historical, Critical, and Sporting Intelligence [1st-7th Ser.]. Printed for the author by Hunter, Rose \& co., 1863.

Le Moine, Roger. “Le Moine, Sir James Macpherson.” Dictionary of Canadian Biography, Vol. 14, Laval UP/Toronto UP, 1998.

Le Risbé, Michèle. "Les mouvements nationalitaire et contre-culturel à travers la chanson québécoise.” Postures, vol. Dossier “L,” no. 3, 2000, pp. 103-18. 
Les filles de Caleb. Directed by Jean Beaudin, performances by Marina Orsini and Roy Dupuis, Radio-Canada, 1990-1991.

Lessard, Gene. Grandfather's Tale: The Story of Human Evolution and Dispersal. CreateSpace Independent Publishing Platform, 2012.

“Le Théâtre de l'Atrium joue ‘Ma Corriveau.”' Le Nouvelliste, 27 Oct. 1978, p. 13.

Létourneau, Jocelyn. A History for the Future: Rewriting Memory and Identity in Quebec, translated by Phyllis Aronoff and Howard Scott, McGill-Queen's UP, 2004.

---. Passer à l'avenir : histoire, mémoire, identité dans le Québec d'aujourd'hui. Boréal, 2000.

Library and Archive Canada. "Stamp Production." Stampsandcanada.com, 15 May 2010, www.stampsandcanada.com/stamps-articles.php?article=stamp-production\&id=5. Accessed 1 Nov. 2020.

Lloyd-Smith, Allan. American Gothic Fiction: An Introduction. Continuum, 2004.

Lord, Michel. En quête du roman gothique québécois, 1837-1860 : tradition littéraire et imaginaire romanesque. Laval UP, 1985.

---. "La fragmentation infinie des (im)possibles : la nouvelle fantastique et de sciencefiction québécoise des origines 1985." La nouvelle au Québec, edited by François Gallays and Robert Vigneault, Fides, 1996, pp. 53-74.

Lyotard, Jean-François. La condition postmoderne : rapport sur le savoir. Minuit, 1979.

---. The Postmodern Condition: A Report on Knowledge, translated by Geoff Bennington and Brian Massumi, Minnesota UP, 1984.

MacDonald, Mary Lu. "Fréchette, Louis." Encyclopedia of Literature in Canada, edited by W.H. New, 2002, pp. 395-297. 
Macdonald, Sharon. "Expanding Museum Studies: An Introduction." A Companion to Museum Studies, edited by Sharon Macdonald, Blackwell Publishing, 2006, pp. 112.

MacInnes, Ranald. "Robert Burns, Antiquarianism and Alloway Kirk: The Perception and Reception of Literary Place-Making and the 'Historic' Monument." Architectural Heritage, vol. 24, no. 1, Nov. 2013, pp. 1-20.

Mackey, Eva. The House of Difference: Cultural Politics and National Identity in Canada. Toronto UP, 2002.

Mackic, Vera. "Gender and the Rhetoric of Occupation." Occupying the "Other": Australia and Military Occupations from Japan to Iraq, edited by Christine de Matos and Robin Gerster, Cambridge Scholars P, 2009, pp. 80-106.

MacLeod, Suzanne, et al. "Part 1: Narrative, Space, Identity.” Museum Making: Narratives, Architectures, Exhibitions, edited by Suzanne MacLeod et al., Routledge, 2012, pp. 1-4.

““Ma Corriveau' au Centre culturel.” Le Nouvelliste, 3 Jun. 1978, p. 24.

"Ma Corriveau - Centre du Théâtre d'Aujourd'hui." Centre Du Théâtre d'Aujourd'hui, www.theatredaujourdhui.qc.ca/corriveau. Accessed 31 Jul. 2020.

“Ma Corriveau prolongée.” Le Devoir, 21 Oct. 1976, p. 15.

Maheu, Pierre. “L’oedipe colonial." Parti pris, vol. 1, no. 9-10-11, 1964, pp. 19-29.

Major, Robert. "Parti Pris.” The Canadian Encyclopedia, Historica Canada, 2013.

Marchand, Philip. "The Problem of the Artist in 16 Categories of Desire." The Art of Desire: The Fiction of Douglas Glover, edited by Bruce Stone, Oberon P, 2004, pp. $130-40$. 
Maria Chapdelaine. Directed by Gilles Carle, performances by Carole Laure and Nick Mancuso, Astral Films, 1983.

Mason, Rhiannon. "Cultural Theory and Museum Studies.” A Companion to Museum Studies, edited by Sharon Macdonald, Blackwell Publishing, 2006, pp. 17-32.

Massicotte, Édouard-Zotique. "Une nuit chez les sorciers." Conteurs canadiens-français $d u X I X^{e}$ siècle, Beachemin \& fils, 1902, pp. 35-52.

Mathews, Adam J., and Matthew T. Patton. "Exploring Place Marketing by American Microbreweries: Neolocal Expressions of Ethnicity and Race.” Journal of Cultural Geography, vol. 33, no. 3, 2016, pp. 275-309.

Mathieu, Jacques. "Seigneurial System.” The Canadian Encyclopedia, Historica Canada, 2013.

McBride, Jessica. "From Vilified to Victorious: Reconceiving La Corriveau in Anne Hébert's La Cage." Studies in Canadian Literature - Études en littérature canadienne, vol. 36, no. 2, 2011, pp. 129-42.

McClintock, Anne. Imperial Leather: Race, Gender, and Sexuality in the Colonial Contest. Routledge, 1995.

McDaniel, June. Lost Ecstasy: Its Decline and Transformation in Religion. Springer, 2018.

McKay, Kristy. "Moisan, Blodgett, and Beyond: Rethinking Comparative Canadian Literature in The Twenty-First Century." Canadian Review of Comparative Literature / Revue canadienne de littérature comparée, 2009, pp. 11-24.

McKenzie, Stephanie. Before the Country: Native Renaissance, Canadian Mythology. Toronto UP, 2007. 
"Meet the Team." Context Creative, www.contextcreative.com/people. Accessed 13 Aug. 2020.

Melançon, Johanne. “Mais que chante l'Ontario français?” Introduction à la littérature franco-ontarienne, edited by Lucie Hotte and Johanne Melançon, Prise de parole, 2010, pp. 153-98.

Mes Aïeux. "La Corrida de la Corriveau." Entre les branches, Disques Victoire, 2001.

Mieder, Wolfgang. Proverbs: A Handbook. Greenwood P, 2004.

Mills, Sean. The Empire Within: Postcolonial Thought and Political Activism in Sixties Montreal. McGill-Queen's UP, 2010.

Miron, Gaston. L'homme rapaillé. Montréal UP, 1970.

Monckton Smith, Jane. Murder, Gender and the Media: Narratives of Dangerous Love. Palgrave Macmillan, 2012.

Monière, Denis. Pour comprendre le nationalisme au Québec et ailleurs. Montréal UP, 2000.

Moser, Walter. “Je me souviens' : analyse d'un lieu de mémoire auto-mobile.” Entre lieux et mémoire : l'inscription de la francophonie canadienne dans la durée, edited by Anne Gilbert et al., Ottawa UP, 2009, pp. 293-316.

Moss, Jane. “Le corp(u)s théâtral des femmes." L'annuaire théâtral, no. 46, 2009, pp. 1532.

---. "Le théâtre francophone en Ontario." Introduction à la littérature franco-ontarienne, edited by Lucie Hotte and Johanne Melançon, Prise de parole, 2010, pp. 71-112.

---. "Women, History, and Theater in Quebec." The French Review, vol. 67, no. 6, 1994, pp. $974-84$. 
Moss, Laura, and Cynthia Sugars. "A New Nationality.” Canadian Literature in English: Texts and Contexts, Vol. 1, edited by Laura Moss and Cynthia Sugars, Pearson Longman, 2009, pp. 251-74.

---. "Canada as Home." Canadian Literature in English: Texts and Contexts, Vol. 1, edited by Laura Moss and Cynthia Sugars, Pearson Longman, 2009, pp. 109-31.

---. "Introduction: Nationalists, Intellectuals, and Iconoclasts." Canadian Literature in English: Texts and Contexts, Vol. 2, edited by Laura Moss and Cynthia Sugars, Pearson Longman, 2009, pp. 213-41.

Murphy, Carl. "The Marriage Metaphor in Nineteenth-Century English Canadian Fiction." Studies in Canadian Literature / Études en littérature canadienne, vol. 13, no. $1,1988$.

Needham, Gary. "Bringing out the Gimp: Fashioning the SM Imaginary." Fashion Theory, vol. 18, no. 2, 2014, pp. 149-68.

Nehring, Neil. "Introduction: The Rolling Stones." Rock Music Studies, vol. 2, no. 3, 2015, pp. 221-25.

Norris, Christopher. What's Wrong with Postmodernism: Critical Theory and the Ends of Philosophy. Johns Hopkins UP, 1990.

Northey, Margot. The Haunted Wilderness: The Gothic and Grotesque in Canadian Fiction. Toronto UP, 1976.

Oliver, Garrett. "Craft Brewing." The Oxford Companion to Beer, edited by Garrett Oliver, Oxford UP, 2012, pp. 270-73.

---. "Imperial." The Oxford Companion to Beer, edited by Garrett Oliver, Oxford UP, 2012, pp. 478-79. 
O’Meara, Maureen. "Living with the Cultural Legacy of La Corriveau: La Cage." The Art and Genius of Anne Hébert: Essays on Her Works: Night and the Day Are One, edited by Janis L. Pallister, Fairleigh Dickinson UP, 2004, pp. 161-78.

O’Neil, Jean. "De la difficulté qu'il y a à faire vivre des légendes." La Presse, 17 Sep. 1976, p. 11.

Paré, François. "Esthétique du Slam et de la poésie orale dans la région frontalière de Gatineau-Ottawa." Voix et Images, vol. 40, no. 2, 2015, pp. 89-103.

---. “La poésie franco-ontarienne." Introduction à la littérature franco-ontarienne, edited by Lucie Hotte and Johanne Melançon, Prise de parole, 2010.

Pariseau, Monique. La fiancée du vent. Éditions Libre Expression, 2003.

Paterson, Janet M. Figures de l'Autre dans le roman québécois. Nota Bene, 2004.

---. "Le postmodernisme québécois : tendances actuelles.” Études littéraires, vol. 27, no. 1, 1994, pp. 77-88.

---. Moments postmodernes dans le roman québécois. Ottawa UP, 1993.

---. Postmodernism and the Quebec Novel, translated by David Homel and Charles Phillips, Toronto UP, 1994.

Pauline Julien. "La Corriveau." Au milieu de ma vie, peut-être la veille de..., Les Disques Zodiaque, 1972.

Pearl, Jonathan L. "Witchcraft in New France in the Seventeenth Century: The Social Aspect." Historical Reflections/Réflexions Historiques, vol. 4, no. 2, 1977, pp. 4155.

Perkins, Pam. “Imagining Eighteenth-Century Quebec: British Literature and Colonial Rhetoric." Is Canada Postcolonial?, edited by Laura Moss, Wilfrid Laurier UP, 
2003, pp. 151-61.

Pigeon, Elaine. “Hosanna! Michel Tremblay's Queering of National Identity.” A Queer Country: Gay and Lesbian Studies in the Canadian Context, edited by Terry Goldie, Arsenal Pulp P, 2011, pp. 27-49.

Piroth, Scott. "Popular Music and Identity in Quebec." American Review of Canadian Studies, vol. 38, no. 2, 2008, pp. 145-64.

Poirier, Lisa J. M. Religion, Gender, and Kinship in Colonial New France. Syracuse UP, 2016.

Pratt, Mary Louise. Imperial Eyes: Travel Writing and Transculturation. Routledge, 1992.

Probyn, Elspeth. Outside Belongings. Routledge, 1996.

Provencher, Jean. Le Carnaval de Québec : la grande fête de l'hiver. Éditions MultiMondes, 2003.

“Quebec Author Will Burn Books to Block Bilingualism.” CBC News, 2008, www.cbc.ca/news/canada/montreal/quebec-author-will-burn-books-to-blockbilingualism-1.735170. Accessed 18 Jul. 2020.

Raudsepp, Enn. "Patriotism and Class Interest in Les Anciens Canadiens." Journal of Canadian Fiction, vol. 30, 1980, pp. 106-13.

Ravary-Pilon, Julie. Femmes, nation et nature dans le cinéma québécois. Montréal UP, 2018.

Rea, Annabelle M. "Marie-Josephte Becomes Ludivine: The Family Reformed in Anne Hébert's La Cage." Doing Gender: Franco-Canadian Women Writers of the 1990s, edited by Paula Ruth Gilbert and Roseanna Lewis Dufault, Fairleigh Dickinson UP, 
2001, pp. 23-35.

Reid, Gregory J. “Anne Hébert's La cage: A Masque of Liberation.” Text \& Presentation, edited by Stratos E. Constantinidis, McFarland, 2008, pp. 132-44.

Reid, Gregory J., and Pamela Grant. "Preface." Two Plays: The Cage and L'Ille de La Demoiselle, translated by Pamela Grant et al., Playwrights Canada P, 2010. pp. iiivii.

"Relics of Two Long-Remembered Deaths Inspired Letter-Writers." The Gazette, 25 Sept. 1994, p. B3.

Renan, Ernest. Qu'est-ce qu'une nation? : conférence faite en Sorbonne, le 11 mars 1882, edited by Lévy Calmann, Ancienne Maison Michel Lévy Frères, 1882.

---. "What is a Nation?" Nation and Narration, edited by Homi K. Bhabha and translated by Martin Thom. Routledge, 1990, pp. 8-22.

Ricou, Laurie. "Editorial: Is Winter My Country.” Canadian Literature, vol. 131, 1991, pp. 3-5.

Rinfret, Fernand. Louis Fréchette. Libr. J.-E. Prévost, 1906.

Robert, Julie. Curative Illnesses: Medico-National Allegory in Québécois Fiction. McGill-Queen's UP, 2016.

Roberts, Katherine A. "Making Women Pay: Revolution, Violence, Decolonizing Quebec in Hubert Aquin's Trou de Mémoire." Québec Studies, vol. 30, no. 1, 2000, pp. 17-27.

Roy, Camille. Etude sur “Les anciens Canadiens.” J. Hope, 1906.

Roy, Fernande. “Nègres blancs d'Amérique?” Liberté, vol. 51, no. 3, 2009, pp. 34-52.

Roy, Joseph-Edmond. Histoire de la seigneurie de Lauzon, s.n., 1900. 
Royal Commission on the University of Durham Report. Proquest LLC, 2008.

Rubin, Josh. "Canada." The Oxford Companion to Beer, edited by Garrett Oliver, Oxford UP, 2012, pp. 210-14.

Ruggiu, François-Joseph. 'Le destin de la noblesse du Canada, de l'empire français à l'empire britannique." Revue d'histoire de l'Amérique française, vol. 66, no. 1, 2012, p. 37.

Saint-Martin, Lori. "Des pères absents aux filles meurtrières et au-delà : le rapport pèrefille en littérature québécoise.” Relations familiales dans les littératures française et francophone des $X X^{e}$ et $X X I^{e}$ siècles : la figure du père, edited by Murielle Lucie Clément and Sabine Van Wesemael, L'Harmattan, 2008, pp. 13-26.

Salée, Daniel. “L’État québécois et la question autochtone." Québec : état et société, tome 2, edited by Alain Gagnon, Québec/Amérique, 2003, pp. 117-47.

---. “The Québec State and Indigenous Peoples." Québec: State and Society, edited by Alain Gagnon and translated by Manon Tremblay, Broadview P, 2004, pp. 97-124. Saunders, Max. Self Impression: Life-Writing, Autobiografiction and the Forms of Modern Literature. Oxford UP, 2010.

Scarpetta, Guy. Éloge du cosmopolitisme. Grasset, 1981.

---. L'impureté. Grasset, 1985.

Seal, Lizzie. Women, Murder and Femininity: Gender Representations of Women Who Kill. Palgrave Macmillan, 2010.

Sharp, Joanne R. “Gendering Nationhood: A Feminist Engagement with National Identity." BodySpace: Destabilising Geographies of Gender and Sexuality, edited by Nancy Duncan, Routledge, 1996, pp. 97-108. 
Shortridge, James R. "Keeping Tabs on Kansas: Reflections on Regionally Based Field Study." Journal of Cultural Geography, vol. 16, no. 1, 1996, pp. 5-16.

Simon, Sherry. Le trafic des langues : traduction et culture dans la littérature québécoise. Boréal, 1994.

Sims, Martha, and Martine Stephens. Living Folklore: An Introduction to the Study of People and Their Traditions. Utah State UP, 2005.

Singh, Jaspal Kaur. Representation and Resistance: South Asian and African Women's Texts at Home and in the Diaspora. Calgary UP, 2008.

Slott, Kathryn. "La remise en question de la Corriveau dans La cage d'Anne Hébert." The Art and Genius of Anne Hébert: Essays on Her Works: Night and the Day Are One, edited by Janis L Pallister, Fairleigh Dickinson UP, 2004, pp. 149-60.

Smart, Patricia. "Our Two Cultures." The Canadian Forum, vol. 64, no. 744, 1984, pp. 14-19.

---. Writing in the Father's House: The Emergence of the Feminine in the Quebec Literary Tradition. Toronto UP, 1991.

Söderlind, Sylvia. Margin/alias: Language and Colonization in Canadian and Québécois Fiction. Toronto UP, 1991.

Sontag, Susan. Illness as Metaphor. Farrar, Straus and Giroux, 1977.

Stacey, Robert. "Romance, Pastoral Romance, and the Nation in History: William Kirby's The Golden Dog and Philippe-Joseph Aubert de Gaspé's Les anciens Canadiens." ReCalling Early Canada, Alberta UP, 2005, pp. 91-116.

St-Amand, Isabelle. La crise d'Oka en récits : territoire, cinéma et littérature. Laval UP, 2015. 
Starks, Tricia. The Body Soviet: Propaganda, Hygiene, and the Revolutionary State. Wisconsin UP, 2008.

Stasiulis, Daiva, and Radha Jhappan. "The Fractious Politics of a Settler Society: Canada." Unsettling Settler Societies: Articulations of Gender, Race, Ethnicity and Class, edited by Daiva Stasiulis and Nira Yuval-Davis, SAGE, 1995, pp. 95-132.

Stevenson, Garth. Parallel Paths: The Developmentof Nationalism in Ireland and Quebec. McGill-Queen's UP, 2006.

Stone, Bruce. “A Writer's Guide to Douglas Glover's Fiction.” The Art of Desire: The Fiction of Douglas Glover, edited by Bruce Stone, Oberon P, 2004, pp. 11-67.

Sugars, Cynthia. Canadian Gothic: Literature, History, and the Spectre of Self-Invention. Wales UP, 2014.

---. "On the Rungs of the Double Helix : Theorizing the Canadian Literatures." Essays on Canadian Writing, no. 50, 1993, pp. 19-44.

Swift, Jonathan. Gulliver's Travels. Oxford UP, 2008.

Szechi, Daniel. "Scottish Jacobitism in its International Context." The Oxford Handbook of Modern Scottish History, edited by T.M. Devine and Jenny Wormald, Oxford UP, 2012, pp. 355-69.

Tardif, Dominic. “La poésie, défense légitime pour l'Ontario français.” Le Devoir, 18 May 2019, www.ledevoir.com/lire/554521/grand-angle-la-poesie-defense-legitimepour-1-ontario-francais. Accessed on 12 Aug. 2020.

Tausky, Thomas E. "Nationalism.” Encyclopedia of Literature in Canada, edited by W.H. New, Toronto UP, 2002, pp. 795-800.

Thério, Adrien, and Michel Lord. "En quête du roman gothique québécois (1837-1860)." 
Lettres québécoises, no. 42, 1986, p. 65.

Thomson, Dale. "Language, Identity, and the Nationalist Impulse: Quebec.” The Annals of the American Academy of Political and Social Science, vol. 538, no. 1, 1995, pp. 69-82.

Thornton McLeod, Joan B. La Corriveau \& the Blond and Other Poems. Bonsecours Editions, 1975.

Thurston, Robert. The Witch Hunts: A History of the Witch Persecutions in Europe and North America. Routledge, 2007.

Titanic. Directed by James Cameron, performances by Leonardo DiCaprio and Kate Winslet, Paramount Pictures, 1997.

Tremblay, Michel. Les belles-soeurs. Leméac, 1972.

Truscott, Carol. "S/M: Some Questions and a Few Answers." Leatherfolk: Radical Sex, People, Politics, and Practice, edited by Mark Thompson, Daedalus, 1991, pp. 1537.

Turcotte, Gerry, and Cynthia Sugars. "Introduction: Canadian Literature and the Postcolonial Gothic." Unsettled Remains: Canadian Literature and the Postcolonial Gothic, edited by Gerry Turcotte and Cynthia Sugars, Wilfrid Laurier UP, 2009, pp. vii-xxvi.

Tyma, Adam W. Beer Culture in Theory and Practice: Understanding Craft Beer Culture in the United States. Lexington Books, 2017.

Vacante, Jeffery. National Manhood and the Creation of Modern Quebec. UBC P, 2017.

---. "Quebec Manhood in Historical Perspective." Canadian Men and Masculinities: Historical and Contemporary Perspectives, edited by Wayne Martino and 
Christopher J Greig, Canadian Scholars' P, 2012, pp. 23-41.

van Lent, Peter. “La vie de l'habitant: Quebec's Folk Culture of Survival.” Explorations in Canadian Folklore, edited by Edith Fowke and Carole H. Carpenter, McClelland and Stewart, 1985, pp. 329-39.

Verduyn, Christl. “Encountering Canada: Immigrant and Ethnic-Minority Writing.” Immigrant and Ethnic-Minority Writers since 1945: Fourteen National Contexts in Europe and Beyond, edited by Wiebke Sievers and Sandra Vlasta, Brill, 2018, pp. 106-50.

Vickers, Jill. “Gendering the Hyphen: Gender Dimensions of Modern Nation-State Formation in Euro-American and Anti- and Post-Colonial Contexts." Gendering the Nation-State: Canadian and Comparative Perspectives, edited by Yasmeen AbuLaban, UBC P, 2008, pp. 21-45.

Vigneault, Gilles. La Corriveau. Nouvelles Editions de l'Arc, 1966.

Vronsky, Peter. Female Serial Killers: How and Why Women Become Monsters. Berkley Books, 2007.

Walker, Deward E. Witchcraft and Sorcery of the American Native Peoples. Idaho UP, 1989.

Walpole, Horace. The Castle of Otranto and The Mysterious Mother, edited by Frederick S. Frank. Broadview P, 2003.

Watteyne, Nathalie, et al. Anne Hébert : chronologie et bibliographie des livres, parties de livres, articles et autres travaux consacrés à son œuvre, edited by Nathalie Watteyne, Montréal UP, 2008.

Wester, Maisha L. "The Gothic and the Politics of Race." The Cambridge Companion to 
the Modern Gothic, edited by Jerrold E. Hogle, Cambridge UP, 2014, pp. 157-73. Wiebe, Joe. Craft Beer Revolution: The Insider's Guide to B.C. Breweries. D\&M Publishers, 2013.

Wilson, William A. "Herder, Folklore, and Romantic Nationalism." The Marrow of Human Experience: Essays on Folklore by William A. Wilson, edited by Jill Terry Rudy and Diane Call, Colorado UP, 2006, pp. 107-23.

Winks, Robin W. "Preface.” Historiography, 1999, pp. xiii-xv.

Winter, Elke. Us, Them, and Others: Pluralism and National Identity in Diverse Societies. Toronto UP, 2011.

Wylie, Herb. “Attack of the 'Latté-Drinking Relativists': Postmodernism, Historiography, and Historical Fiction.” RE: Reading the Postmodern: Canadian Literature and Criticism after Modernism, edited by Robert David Stacey, Ottawa UP, 2010, pp. 183-202.

Yeoman, Louise. "Hunting the Rich Witch in Scotland: High-Status Witchcraft Suspects and Their Persecutors, 1590-1650." The Scottish Witch-Hunt in Context, edited by Julian Goodare, Manchester UP, 2002, pp. 106-21.

Young, Francis. A History of Exorcism in Catholic Christianity. Palgrave Macmillan, 2016.

Yuval-Davis, Nira. Gender \& Nation. SAGE, 1997.

Zaccaria, Paola. "Translating Borders, Performing Trans Nationalism.” Human Architecture: Journal of the Sociology of Self Knowledge, vol. 4, 2006, pp. 57-70. 